\title{
Bauhinia ser. Cansenia (Leguminosae: Caesalpinioideae) no Brasil
}

\author{
Angela Maria Studart da Fonseca Vaz ${ }^{1}$ \\ A. M. G. Azevedo Tozzi ${ }^{2}$
}

\begin{abstract}
RESUMO
Este trabalho fornece chave para identificação, sinonímia, descrição, distribuição geográfica e habitat, comentários sobre taxonomia para 35 espécies e 4 variedades de Bauhinia sect. Pauletia ser. Cansenia, nativas no Brasil. Além disso, o capítulo introdutório oferece um estudo preliminar dos caracteres morfológicos e relação inter-específica dos táxons estudados. O tratamento taxonômico é baseado em mais de 1.200 coleções e também em várias duplicatas destas coleções depositadas em mais de 60 herbários. Os caracteres taxonômicos também foram observados em árvores de 3 espécies cultivadas no Instituto de Pesquisas Jardim Botânico do Rio de Janeiro. Observações de campo foram feitas nos estados do Rio de Janeiro, Bahia, Goiás e no Distrito Federal. Duas novas ocorrências - B. cinnamomea e $B$. conwayi - são relatadas para o Brasil. Três novas combinações para as variedades de B. ungulata são propostas. Vinte e nove sinônimos taxonômicos (heterotípicos) são aceitos, destes, 25 são apresentados pela primeira vez. A distribuição dos táxons de Bauhinia ser. Cansenia no Brasil foi assinalada em 9 mapas. Dezenove pranchas ilustrativas são apresentadas.
\end{abstract}

Palavras chaves: Leguminosae, Bauhinia, Taxonomia, Brasil

\begin{abstract}
This treatment provides a key to identification, synonymy, description, geographic distribution and habitat, taxonomic comments for 35 species and 4 varieties of Bauhinia sect. Pauletia ser. Cansenia, native to Brazil. Besides this, the introdutory chapter offers a preliminary study of the morphological characters and interspecific relationship of studied taxa. The taxonomic treatment presented is based on more than 1200 herbarium collections and several duplicates (sheets) of most of these collections of more than 60 herbaria. Taxonomic characters were also observed on trees of 3 species cultivated at Instituto de Pesquisas Jardim Botânico do Rio de Janeiro. Field observations were made at Rio de Janeiro, Bahia, Goiás states and Federal District. Two new occurrences of species for Brazil-B. cinnamomea e $B$. conwayi - are recorded. A new name (replacement name) - Three new combinations are proposed. Twenty nine taxonomic (heterotypic) synonyms are accepted and 25 of them are presented here for the first time. The distribution of the studied taxa of Bauhinia ser. Cansenia is shown in 9 maps. Nineteen illustrative plates are presented.
\end{abstract}

Key words: Leguminosae, Bauhinia, Taxonomy, Brazil

${ }^{1}$ Fundação Instituto Brasileiro de Geografia e Estatística/Pesquisador conveniado do Instituto de Pesquisas Jardim Botânico do Rio de Janeiro. Rua Pacheco Leão 915, CEP 22460-030. Rio de Janeiro, RJ, Brasil. email: amvaz@jbrj.gov.br ${ }^{2}$ Universidade Estadual de Campinas, Inst.Biologia, Depto. Botânica, Cx. Postal 6109, CEP 13081-970, Campinas, SP, Brasil. 


\section{INTRODUÇÃO}

Bauhinia Plum. ex L. é um gênero pantropical, com cerca de 300 espécies, pertencente à Leguminosae, subfamília Caesalpinioideae, tribo Cercideae (Wunderlin, Larsen \& Larsen, 1987). Bentham (1870) tinha revisado as espécies brasileiras do gênero Bauhinia, com base nos tratamentos anteriores de Bongard (1836) e Vogel (1839), acrescentando ainda várias espécies novas. Reconheceu 64 espécies distribuídas em 3 seções, sendo uma delas a seção Pauletia. Um levantamento da situação atual do conhecimento do gênero Bauhinia no Brasil encontra-se em Vaz (2001). Verificou-se que as noventa e oito espécies de Bauhinia do Brasil enquadram-se, agora, em seis seções: Amaria (S. Mutis) Endl., Bauhinia, Benthamia Fortunato \& Wunderlin, Caulotretus DC., Pauletia (Cav.) DC. eSchnella (Raddi) Benth., correspondentes a três dos quatro subgêneros propostos por Wunderlin, Larsen \& Larsen (1987).

O táxon Pauletia foi proposto inicialmente na categoria de gênero por Cavanilles (1799). A seção Pauletia foi proposta por De Candolle (1825). A seção Pauletia pode ser reconhecida pela combinação dos seguintes caracteres: androceu apresentando filetes conados na base, formando internamente uma coluna irregular, curta e com apêndices ligulares conspícuos ou rudimentares (obsoletos) até ausentes; grãos de pólen, em geral, com sexina reticulada e com processos gemóides supratectais.

Wunderlin, Larsen \& Larsen (1987) estabeleceram 5 novas séries sob a seção Pauletia, no subgênero Bauhinia: 1. Bauhinia ser. Cansenia (Raf.) Wunderlin, Larsen \& Larsen; 2. Bauhinia ser. Acuminatae Wunderlin, Larsen \& Larsen; 3. Bauhinia ser. Ariaria (Cuervo Marques) Wunderlin, Larsen \& Larsen; 4. Bauhinia ser. Pentandrae Wunderlin, Larsen \& Larsen e 5. Bauhinia ser. Perlebia (Mart.) Wunderlin, Larsen \& Larsen.

Vaz \& Tozzi (2003) propuseram uma nova circunscrição para Bauhinia ser. Cansenia com a criação de uma nova série, Bauhinia ser.
Aculeatae Vaz \& A.M.G. Azevedo. A circunscrição de Bauhinia ser. Cansenia emendavit Vaz \& A.M.G. Azevedo coincide com o primeiro dos grupos informais da seção Pauletia (Bentham, 1870: espécies 1-29), porém, com exclusão de $B$. marginata e com inclusão de $B$. cheilantha, tratada por Bentham em um outro grupo e ainda, com acréscimos de novas espécies descritas posteriormente.

O objetivo do presente trabalho é apresentar a primeira parte de uma revisão de Bauhinia sect. Pauletia no Brasil, correspondente às espécies da série Cansenia.

Bauhinia ser. Cansenia é claramente um grupo bem definido e reconhecido pelo tipo de inflorescência terminal áfila, aqui denominada pseudo-racemo com brácteas foliáceas, além da bráctea floral e respectivas bractéolas, associado a grãos de pólen do tipo 3-(4-) colpados, angulo-aperturados.

\section{MATERIAL E MÉTODOS}

Foram consultados espécimes herborizados, procedentes dos seguintes herbários, aqui citados pelas siglas, de acordo com Holmgren et al. (1990): ASE, HCB, BHMH, BM, BOTU, C, CEN, CEPEC, CEUL, CGMS, CH, CPAP, CRI, CTES, CVRD, E, EAC, ESA, F, FACB, FUEL, GRAH, GUA, HAC, HB, HEPH, HISA, HRCB, HRB, HUEFS, HUFU, IAC, IAN, ISA, IBGE, INPA, IPA, JPB, K, MBM, MBML, MEXU, MG, MO, NX, NY, OXF, OUPR, P, R, RB, RBR, RFA, RUSU, S, SI, SINU, SJRP, SP, SPF, SPFR, UB, UEC, UFG, ULM, US, VIC e W. Além disso, foram examinadas fotografias de tipos nomenclaturais enviadas pelos herbários A, B, F, K, LE, M, MA e NY. Procedeu-se, então, à revisão dos nomes dos táxons de acordo com o Internacional Code of Botanical Nomenclature (Greuter et al. 2000) e, em seguida, à sinonimização daqueles não aceitos.

Os trabalhos de campo, realizados no ano 1996, tiveram o objetivo de observar a variação morfológica e de associar os diferentes hábitos com o tipo de habitat, dentro de um determinado contexto fitogeográfico de cerrado (Goiás e 
Reserva Ecológica do IBGE, no Distrito Federal) e Floresta Atlântica (Bahia, Rio de Janeiro). As coleções Vaz et al. foram depositadas nos herbários IBGE, RB e UEC.

Os principais caracteres diagnósticos foram ilustrados com auxílio de câmara clara Zeiss. As pranchas apresentadas foram confeccionadas em nanquim, pelas ilustradoras Aline de Souza Oliveira e Glória Gonçalves.

As informações sobre a distribuição geográfica, ecologia, floração e frutificação foram obtidas nas etiquetas dos espécimes estudados e a partir de observações de campo. No ítem distribuição geográfica e habitat é dada a ocorrência das espécies, por Folha Geográfica IBGE (1960). A ocorrência por folha foi obtida indiretamente, a partir da localidade de ocorrência de cada espécime, através de consulta ao Índice dos Topônimos Contidos na Carta do Brasil (Vanzolini \& Papavero, 1968). Uma relação completa do material examinado pode ser consultada em Vaz (2001). Além disso, pontos selecionados para cada espécie foram assinalados no mapa Flora Neotropica 103.

A citação de exsicatas no texto se dá através da abreviatura col., seguida do nome do coletor principal e respectivo número da coleção. A lista de exsicatas examinadas está no Anexo 1.

Os tipos de indumento foram adotados segundo o glossário de termos de Stearn (1973) e Payne (1978). O termo legume é adotado no sentido amplo (Dudik, 1981; ver, também, Barroso et al. 1999). As medidas de caracteres foliares foram extraídas de ramos floríferos ou frutíferos, não se levando em consideração caracteres em ramos estéreis de rebrotos. Os caracteres frutíferos correspondem aos de frutos já desenvolvidos. O entrenó distal é aqui definido como a distância entre as duas folhas apicais (distais) do ramo estéril. O pedúnculo é representado pela distância entre a folha distal e a bráctea foliácea (ou folha reduzida) imediatamente abaixo do par proximal de flores geminadas. As medidas do pedicelo, hipanto, pétala, coluna estaminal foram realizadas na flor aberta, ainda com pétalas. A medida da largura do botão floral corresponde sempre à parte mais larga do botão na pré-antese. O comprimento da coluna estaminal foi medido internamente, tendo como referência a inserção das sépalas inferiores e a altura máxima da coluna.

\section{RESULTADOS E DISCUSSÃO Hábito, forma de vida e sistemas subterrâneos}

As espécies de Bauhinia ser. Cansenia são lenhosas e eretas, às vezes, com ramos flexíveis apoiantes, mas nunca são lianas com gavinhas. A casca das formas arbóreas é pardoacinzentada, geralmente com manchas liquênicas, longitudinalmente fissurada, com estrias transversais pouco nítidas não chegando a fo-mar escamas.

As formas de vida apresentadas pelos indivíduos de Bauhinia ser. Cansenia, foram observadas em viagens de campo. Em formações florestais os indivíduos adultos apresentaram o hábito de arvoretas, correspondendo a microfanerófitos, comumente entre 5 e 15 metros de altura. Em formações campestres e nos cerrados abertos submetidos a queimadas periódicas, eram tipicamente subarbustos sensu Rizzini (1976: p. 295) geralmente entre 0,5 e 2 metros, correspondendo também aos xeromórfitos de Veloso (1992).

A tendência à redução do porte, expressa pela forma de subarbusto com xilopódio (xeromórfito) em algumas espécies é aqui evidenciada como um caráter exclusivo para a série Cansenia, portanto ausente nas demais séries e, possivelmente, em todo o gênero Bauhinia. $\mathrm{O}$ xilopódio é um órgão subterrâneo tuberculoso-lenhoso encontrado em plantas dos campos e campos cerrados do Brasil (Rizzini \& Heringer, 1961, 1962; Rizzini, 1965). A parte apical do xilopódio, que fica exposta na superfície do solo, possui forte capacidade de emitir novas gemas adventícias que produzem periodicamente novos ramos aéreos após a estação seca e/ou queimadas. Algumas espécies de Bauhinia ser. Cansenia, quando 

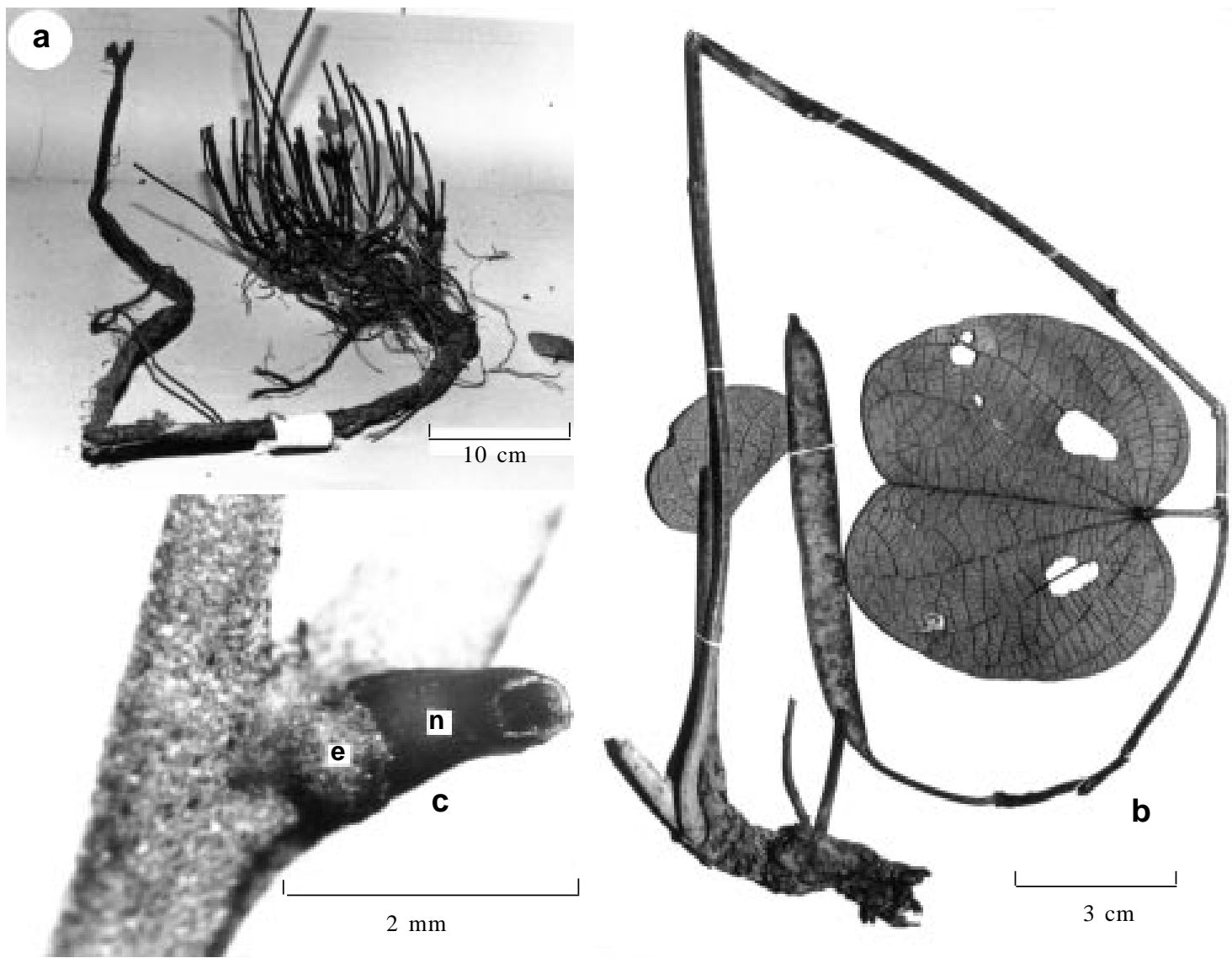

Figura 1 - Xilopódio e nectário extrafloral em Bauhinia ser. Cansenia: Bauhinia dumosa var. viscidula (Marquete 2121): a: Xilopódio, do qual se originam diversos ramos aéreos e que se continua em raiz horizontal que corre paralela à superfície, procedente de campo cerrado, no Distrito Federal. Bauhinia rufa (Marquete 2123): b: Espécime herborizado, com xilopódio e ramo frutífero, procedente do cerrado do Distrito Federal. Bauhinia curvula (foto M. H. Rezende): c: Nectário extrafloral na base do pecíolo; $\mathbf{n}=$ nectário extrafloral; $\mathbf{e}=$ estípula.

na forma subarbustiva apresentam xilopódios cuja morfologia externa pode ser específica. Por exemplo, Bauhinia rufa e B. holophylla apresentam xilopódio robustos, enquanto $B$. dumosa var. viscidula apresenta xilopódio delgado (Figs 1a,1b). Os indivíduos subarbustivos, portadores de xilopódio observados em uma população de $B$. holophylla em Brasília (leg. Vaz 917) eram interligados em série por um sistema subterrâneo secundário, de calibre mais fino e que corria paralelamente e próximo da superfície e do qual partiam rebrotos aéreos de espaço a espaço. Esse modo de propagação vegetativa foi estudado para Casearia sylvestris, admitindo-se a existência de populações clonais (Paviani \& Magalhães, 1996).

Nas áreas antropizadas foram encontradas formas de resistência, arbustivas multicaules por rebrotamento. Os indivíduos, nessa forma foram encontrados em capoeiras, ao longo de estradas de terra ou, ainda, como invasores de pastos e, em terrenos baldios.

\section{Padrões de desenvolvimento dos ramos e período de floração}

Observações realizadas em indivíduos adultos de Bauhina cupulata, B. longifolia e $B$. ungulata mostraram que o desenvolvimento dos ramos novos segue o rítmo das estações seca ou chuvosa. Durante a estação chuvosa, 
ocorre a reativação das gemas adventícias apical e/ou laterais e observa-se o início do desenvolvimento de ramos novos. Em um dado momento, após o alongamento dos entrenós, da expansão e crescimento de uma série de novas folhas, sem solução de continuidade, as gemas superiores passam a emitir a parte fértil do ramo com uma sucessão de botões florais formando um tipo de inflorescência afila, a qual foi denominada pseudo-racemo por Urban (1885). Aqui, o desenvolvimento das folhas é drasticamente reduzido ou cessa ou, ainda, são produzidas apenas folhas atrofiadas (vestígios foliares) até, paulatinamente, serem emitidas brácteas de primeira ordem (brácteas foliáceas). Na estação seca, após a floração, maturação dos frutos e liberação das sementes a parte fértil dos ramos, desenvolvida na estação chuvosa anterior, transformada em raque do pseudo-racemo, definha, seca e cai, enquanto a parte estéril inferior do ramo sofre caducifolia gradativa. No início da estação chuvosa seguinte novas gemas adventícias são reativadas originando novos ramos, que sofrerão os mesmos processos de floração, frutificação e definhamento na estação seca posterior. Nas espécies observadas não ocorre reativação de crescimento vegetativo na região distal dos eixos já floridos, devido à adaptação deste eixo à função de raque da inflorescência. As arvoretas de Bauhinia cupulata, B. longifolia e $B$. ungulata apresentaram um período de floração entre seis e sete meses de duração. Neste período, inclui-se cerca de 3 meses correspondentes ao intervalo entre o desenvolvimento dos botões muito jovens até a abertura das duas primeiras flores.

\section{Nectários extraflorais e Acúleos}

Os nectários extraflorais em Bauhinia ser. Cansenia são projeções não-pungentes e secretoras, ocorrentes aos pares e envolvidas, em parte, pela porção basal da estípula. São encontrados, também, em espécies das séries Acuminatae e Ariaria. Na série Cansenia os nectários são pouco robustos até rudimentares e medem entre 0,5-1,5 mm. Os nectários extraflorais também são encontrados no eixo dos pseudo-racemos partindo de brácteas de primeira ordem (bráctea foliácea) e exibindo diferentes formas de acordo com as espécies.

Bentham (1870) não distingiu acúleo de nectário, sendo este último denominado de "acúleo obsoleto". Pijl (1952: p. 292) apontou que em uma espécie americana, não identificada, a estrutura semelhante ao acúleo era na verdade representada por uma estrutura secretora de néctar ("a nectar secreting thread"). Rezende et al. (1994) ao estudar a anatomia foliar de B. curvula, reconheceu, junto às estípulas, um par de nectários extraflorais (Fig. 1c). Considera-se aqui, na ausência de referência a estudos estruturais, a presença/ ausência de nectários extra-florais como um caráter taxonômico ao nível de série, não homólogo ao caráter presença/ausência de acúleos.

Os acúleos faltam completamente, sem formas transitórias ou rudimentares, em Bauhinia ser. Cansenia e, também, faltam nas séries Acuminatae e Ariaria. Os acúleos, no gênero Bauhinia só ocorrem nas séries Aculeatae, Perlebia e Pentandrae (Fig. 4c).

\section{Indumento}

Dois tipos de tricomas - glandulares e tectores - são encontrados no indumento presente nos ramos jovens, pecíolo, dorso da folha, no eixo da inflorescência e no botão floral da maioria das espécies de Bauhinia sect. Pauletia. Os tricomas glandulares ("boatshaped trichomes") são estruturas infladas, afundadas na epiderme e, com forma naviculada, composta de um pedicelo curto e uma "cabeça" multicelular - com uma só camada celular formada por células poligonais em vista superficial, as quais delimitam uma cavidade onde se acumulam substâncias secretadas ou óleos essenciais (Solereder, 1908; Rezende \& al., 1994; Donato, 1995). Foram ilustrados pela primeira vez, com base em Bauhinia brevipes (Solereder, 1908: Fig. 63C) e por Metcalf \& Chalk (1950: Fig.109C). Os tricomas glandulares naviculados observados 

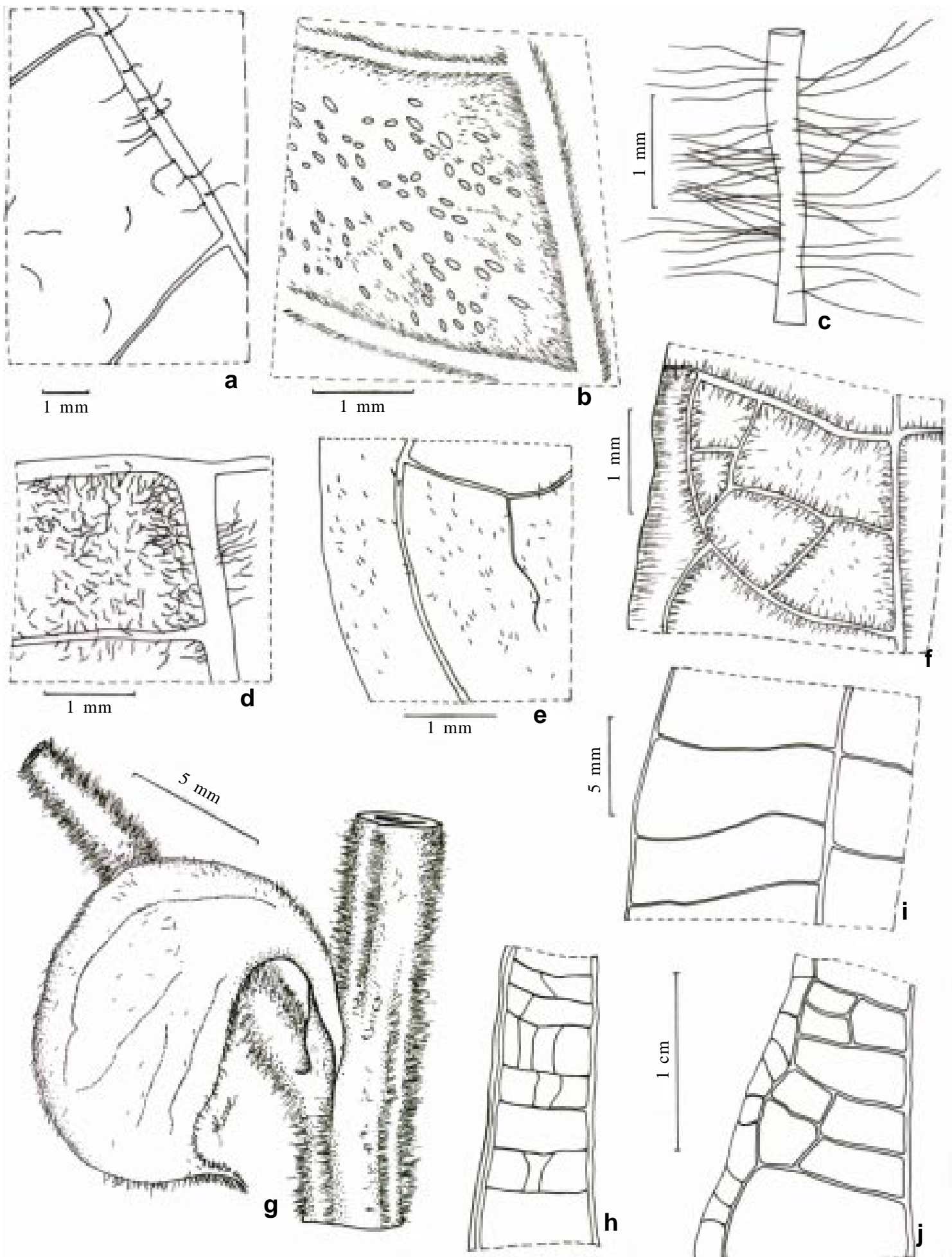

Figura 2 - Tipos de indumento em Bauhinia ser. Cansenia (a-f), a: piloso; b: pubescente. Note as glândulas naviculadas, ocasionalmente presentes; c: hirsuto; d: viloso; e: pubérulo; f: hirsútulo. Estípula e margem foliar em Bauhinia ser. Cansenia (g-j). Bauhinia cheilantha (Malme 2627): g: Estípula semilunar; Bauhinia smilacifolia (Gardner 3698): h: Margem elevado-proeminente; Bauhinia grandifolia (Ducke 23419): i: Infra-nerviforme; Bauhinia cupulata (Gardner 2529): j: Não aplanada. 
em folhas de B. curvula por Rezende et al. (1994: fig 7) têm estrutura semelhante aos de $B$. brevipes. Os tricomas tectores são filamentosos, simples, unisseriados e multicelulares e foram estudados em folhas de Bauhinia curvula (Rezende et al., 1994).

Autores do século XIX, em especial Bongard (1838), Vogel (1839) e Bentham (1870) utilizaram o caráter tipo de indumento foliar e, ocasionalmente, de partes florais no diagnóstico de novas espécies. Com o aumento das coleções tem-se observado que o caráter indumento é de difícil aplicação para o nível de espécie, pois é de difícil definição, é instável, isto é, não ocorre de maneira constante nos espécimes examinados e apresenta variabilidade de tamanho, cor e qualidade em espécimes procedentes, de uma mesma localidade.

Os tipos de indumento ou ausência deste, observados na face inferior da folha das espécies estudadas em Bauhinia ser. Cansenia, sob a lupa estereoscópica (objetiva $3,2 x)$ revelaram três padrões de ocorrência:

1. Indumento ausente (face inferior glabra), por exemplo em Bauhinia platyphylla e B. smilacifolia;

2. Indumento formado por tricomas apressos: pubescente, se curtos e esparsos (Fig. 2b) ou pubérulo, se curtíssimos e esparsos (Fig. $2 \mathrm{E}$ ); ou tomentelo, se em maior concentração;

3. Indumento formado por tricomas não apressos: hirsuto - tricomas patentes, longos e concentrados (Fig. 2c); piloso tricomas longos e esparsos (Fig. 2a); viloso - tricomas de tamanho intermediário e flexuosos (Fig. 2d); hirsútulo - tricomas menores e não flexuosos como em $B$. cheilantha (Fig. 2f); ou, tomentoso tricomas mais adensados, como em $B$. dumosa e B. malacotricha.

Os padrões detectados, glabro, tricomas apressos, tricomas não apressos corresponderam, na prática, a três grupos de espécies na série Cansenia, mas o reconhecimento dos tipos qualitativos de indumento é difícil, devido às nuances entre um tipo de indumento e outro. Além disso, em algumas espécies foi detectado mais de um tipo de indumento, em espécimes diferentes.

\section{Folha}

A folha no gênero Bauhinia é inconfundível por apresentar nervação palmatinérvea, associada ao pecíolo com duas articulações: uma articulação basal (pulvino primário) e uma articulação apical junto à lâmina (pulvino secundário). Além de uma articulação na base da lâmina, denominada almofada motora ("special motile cushions" or "laminar joints"), responsável pelos movimentos nictinásticos singulares; e ainda um mucro apical ou situado entre os folíolos, no caso de separação total destes (Pijl, 1952). Uma maneira prática de distinguir Bauhinia de outros gêneros com folha bifoliolada, é que em Bauhinia nunca há peciólulos perfeitamente individualizados, como ocorre em Hymenaea e Peltogyne. Não existe unanimidade entre os autores - chamados "fusionists" ou "splitters" por Pijl (1952), sobre o caminho evolutivo da folha em Bauhinia, daí a dificuldade em interpretar a folha de Bauhinia, do ponto de vista da composição foliar. Uma sugestão interessante é a de Watari apud Pijl (1952), de que as folhas de Bauhinia e Cercis podem ser classificadas como um caso derivado de folhas compostas palmadas multifolioladas. Aqui, optamos por adotar a tese fusionista considerando a folha de Bauhinia como uma forma derivada de folha composta bifoliolada, cujos folíolos se apresentam fusionados em distintos graus ou, são livres entre si e, cujos peciólulos foram suprimidos.

Para efeito de padronização da descrição morfológica em Bauhinia ser. Cansenia adotamos os seguintes termos: 1) folhas inteiras - correspondentes a folhas aparentemente simples, devido ao fusionamento total de ambos os folíolos; 2) folhas bilobadas - folíolos concrescidos (fusionados) em mais de $1 / 3$ até $2 / 3$ ou menos do comprimento total do folíolo; ou ainda 3) folhas bifolioladas, quando o pecíolo apresenta o mucro situado no ápice do pulvino, 
separando totalmente os folíolos. As espécies do primeiro grupo podem apresentar ápice emarginado ou muito curtamente bilobado, as espécies do terceiro grupo podem apresentar os folíolos concrescidos na base, geralmente em um comprimento menor que $1 / 3$ do comprimento total do folíolo. O caráter grau de bipartição deve ser aplicado com ressalvas, pois algumas espécies com folha inteira podem apresentar, no mesmo espécime, folhas emarginadas a curtamente bilobadas. Do mesmo modo, as espécies com folhas bifolioladas podem apresentar folhas com lobos concrescidos apenas na base.

O comprimento das folhas em Bauhinia ser. Cansenia varia desde cerca de $1 \mathrm{~cm}$, em B. tenella, até o de $32 \mathrm{~cm} \mathrm{em} \mathrm{B.} \mathrm{bombaciflora.}$ Não foram detectadas descontinuidades marcantes entre os intervalos de valores, referentes às dimensões foliares. No entanto, as espécies com folhas bifolioladas apresentam folhas menores, por exemplo $B$. tenella, $B$. curvula e $B$. dumosa. De modo geral, espécimes procedentes da floresta amazônica, de área úmidas e sombrias, apresentam folhas tênue-cartáceas, com ápice acuminado e nervação pouco proemimente na face inferior. Por outro lado, espécimes procedentes de áreas campestres e de cerrado aberto apresentam folhas coriáceas, com ápice obtuso a arredondado ou subtruncado.

As espécies de Bauhinia ser. Cansenia podem ser divididas em três grupos quanto a nervação na face inferior da folha: 1: Espécies com nervação primária ("nervos", sensu Bentham, 1870), nervação secundária ("veias", sensu Bentham 1870) e nervação terciária ("vênulas", sensu Bentham 1870) todas muito proeminentes a proeminentes, como em $B$. bombaciflora e $B$. cupulata. 2: Espécies com nervação secundária e terciária mais ou menos proeminentes a pouco proeminentes, como em B. acuruana e B. cheilantha. 3: Espécies com nervação primárias secundárias e terciárias pouco proeminentes a imersas, como em B. curvula, B. tenella, B. ungulata.

Bauhinia smilacifolia é a única espécie que apresenta nervura marginal proeminente ("nerviforme cincta" segundo Bentham, 1870) (Fig. 2h), B. cinnamomea, B. grandifolia e $B$. urocalyx têm nervura marginal elevada só na face inferior, ou seja, apresentam nervura marginal infra-nerviforme (Fig. 2i); B. curvula, B. pulchella têm nervura marginal aplanada, isto é em um mesmo plano que as nervuras secundárias e as espécies restantes, apresenta nervura marginal inconspícua (Fig. 2j).

\section{Estípulas}

As estípulas em Bauhinia ser. Cansenia são submilimétricas e ditas rudimentares ou não foram vistas em 16 espécies estudadas. Quando plenamente desenvolvida, a forma da estípula pode constituir-se em um caráter para reconhecimento ao nível específico, como em B. cheilantha (Fig. 2g), porém, as estípulas podem não estar presentes em alguns espécimes. Em B. ungulata var. ungulata as estípulas são também únicas, e apresentam formato ovado-lanceolado, oblanceolado ou falcado-oblongo, mas, também podem faltar ou serem precocemente caducas. Outros formatos de estípulas ocorrem, ocasionalmente, em grupos de espécies como, por exemplo, a forma assimétrico-subovada em $B$ bombaciflora e $B$. cupulata. Um outro grupo de espécies apresenta estípula desde lanceolada a linear, como em B. acuruana. Em B. caloneura a base da estípula é concrescida com um vestígio de nectário. Em B. conwayi a base da estípula é assimetricamente dilatada, devido ao volume apresentado pelo nectário extrafloral bem desenvolvido.

\section{Inflorescência}

Em Bauhinia ser. Cansenia, a inflorescência é composta de um "eixo principal" onde estão inseridas, sucessivamente, as inflorescências parciais, constituídas, em geral, de um par de flores geminadas. Uma das flores do par é sempre "mais velha" que a flor companheira (Fig. 3a). Esse tipo de inflorescência foi descrito como "racemo terminal áfilo" (Bentham 1870) e por Urban 
(1885) como "scheintraube" (pseudo-racemo). Trata-se de uma estrutura altamente especializada, onde as flores geminadas são dispostas em plano frontal ao da inserção das folhas ou da bráctea foliácea, estas inseridas, lateralmente, a cada $180^{\circ}$. Os segmentos sucessivos do eixo da inflorescência, região correspondente aos entrenós florais, sofrem torção acentuada, ora à esquerda, ora à direita. Além disso, o eixo apresenta dorsiventralidade acentuada, como por exemplo, em $B$. longifolia (Figs. 3b, c). O número básico de flores, em cada inflorescência parcial é três, ou seja, há evidências de que a inflorescência parcial original seria composta de uma tríade. Esse número, no entanto, pode variar, em diferentes espécies, desde uma flor, constituindo-se mônades, como em B. bombaciflora (Fig.4b) ou duas flores, constituindo-se díades, na maioria das espécies; até três flores por segmento, constituindo-se tríades, como, por exemplo, em B. acuruana (Fig. 4a). Em algumas espécies, cujas inflorescências parciais são compostas por díades, é freqüente a ocorrência de brácteas florais subtendentes "vazias", ocupando posição correspondente à da terceira flor ou de botões abortados e, que sofreram abscisão precoce, como em $B$. longifolia (Fig. 3b). Não existe descontinuidade abrupta entre a parte vegetativa do ramo e o pseudo-racemo terminal áfilo. O entrenó foliar do ramo, ainda estéril, situado imediatamente abaixo da inflorescência é denominado aqui, de entrenó distal. A distância correspondente a esse entrenó tende a ser maior, entre 4,5 e $13 \mathrm{~cm}$, em algumas espécies subarbustivas campestres, como Bauhinia campestris (Fig. 8a), B. goyazensis e B. malacotrichoides. O "pedúnculo" é definido como a região compreendida entre a folha vegetativa distal e inflorescência parcial proximal. Às vezes, o "pedúnculo" pode ser longo como em B. campestris. As brácteas foliáceas estão presentes no eixo floral, substituindo as folhas vegetativas (Fig. 3b, c, "bra f"; ver tópico também brácteas, brácteolas e pedicelos).
Os pseudo-racemos em Bauhinia ser. Cansenia, de acordo com a espécie, podem apresentar modificações secundárias, por exemplo, em B. cupulata, onde por desativação do crescimento apical e reativação das gemas reprodutivas proximais do eixo, originam-se novos eixos de primeira ordem, dando à inflorescência um aspecto paniculiforme (Fig. $10,4 \mathrm{~d}$ ); ou o aspecto corimbiforme, com alongamento dos entrenós distais da parte estéril do ramo e do pedúnculo, com encurtamento dos segmentos distais do eixo principal da inflorescência e redução do número total de flores como em B. campestris (Fig. 8) ou ainda, com segmentos do eixo articulados como em $B$. bombaciflora (Fig. 4b).

\section{Brácteas, bractéolas e pedicelo}

Em Bauhinia ser. Cansenia, o eixo do pseudo-racemo terminal áfilo apresenta uma bráctea foliácea, homóloga às folhas, além de uma bráctea floral subtendente situada na porção proximal do pedicelo e duas bractéolas. A bráctea foliácea tem uma estrutura vestigial, ou seja, consiste em geral, de uma parte central, correspondente lâmina foliar ou ao múcron foliar, ladeada por duas partes laterais concrescidas, que correspondem às estípulas vestigiais, as quais, por sua vez, podem abrigar nectários extraflorais (Figs 3b-d, 4d "bra f"). A bráctea subtendente da flor (Fig. 3b "bra s") e as bractéolas (Fig. 3b "bract") ocupam posições diferentes e possuem formatos distintos, porém as dimensões da bráctea subtendente são sempre maiores (Figs 3b, 4b). Em B. bombaciflora e B. cupulata, porém, as brácteas e bractéolas são concrescidas, em parte, adquirindo formato cupuliforme (Fig. 4b). $O$ pedicelo mede entre 0,2 e $4,5 \mathrm{~cm}$.

\section{Botões, hipanto e cálice}

O botão floral na seção Pauletia é, de modo geral, tubuloso. É composto pelo hipanto cilíndrico ("calycis tubus", Bongard, 1838; Bentham, 1870) que continua no cálice propriamente dito, formado por cinco segmentos. Os segmentos do cálice no botão 

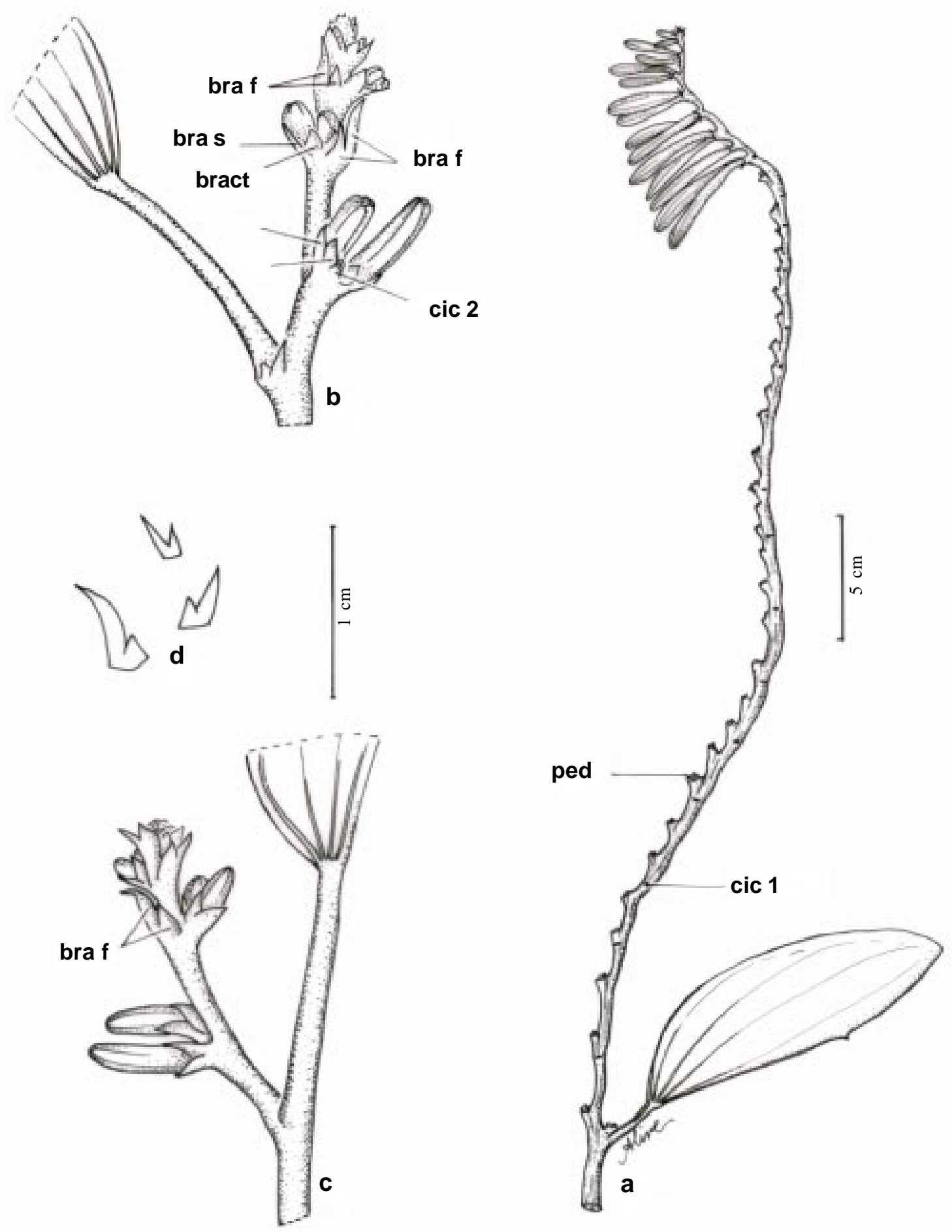

Figura 3 - Inflorescência em B. ser. Cansenia. Bauhinia longifolia (Vaz \& Quinet 1034): a: Aspecto do pseudo-racemo no final da floração e sem frutificação. b: Porção distal do eixo em vista frontal. c: Mesmo segmento em vista dorsal. d: Brácteas foliáceas isoladas (note a variação no tamanho e na forma ). bra f = bráctea foliácea; bra s = bráctea subtendente; bract $=$ bractéola; cic 1 = cicatrizes de brácteas foliáceas; cic 2 = cicatriz de botão vestigial; ped = cicatrizes dos pedicelos geminados. Desenho de Aline Souza de Oliveira, 2000. 


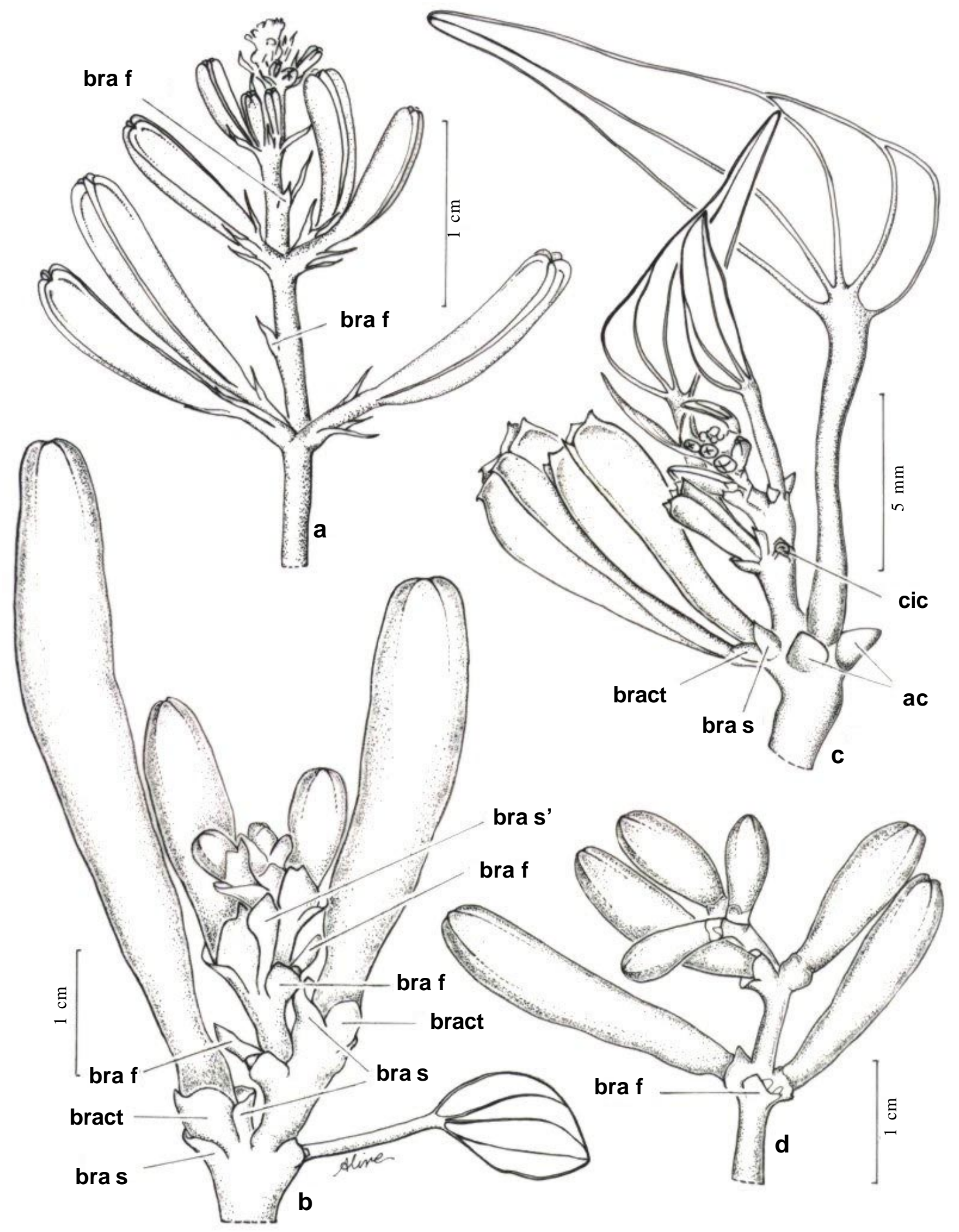

Figura 4 - Pseudo-racemo em Bauhinia ser. Cansenia (a,b,d). B. acuruana (Hatschbach 67683). a: flores em tríades; $B$. bombaciflora (Sarmento 594). b: flores em mônades, cada uma, oposta a uma bráctea foliácea; B. cupulata (Gardner 2529). d: flores em díades. Note o ápice da inflorescência definido, com botão terminal. Inflorescência em Bauhinia ser. Pentandrae (c). B. pentandra (Marquete 2198): c: região apical do ramo florífero. bra f = bráctea foliácea; bra s = bráctea subtendente da flor; bra s' = bráctea subtendente, sem o botão correspondente; bract = bractéola; cic $=$ cicatriz do botão floral. Desenho de Aline Souza de Oliveira, 2000. 
são visivelmente mais membranáceos nas suturas, através da qual se dá a abertura do botão (Urban, 1885).

Na série Cansenia o contorno do botão floral, na pré-antese, tem algum significado taxonômico para o reconhecimento de determinados grupos de espécies (Fig. 5). Os botões de espécies com flores menores, têm entre 3 e $5 \mathrm{~cm}$ de comprimento na pré-antese e os maiores chegam a $20 \mathrm{~cm}$ de comprimento em B. bombaciflora. Na série Cansenia, os botões sofreram uma torção no pedicelo e também um achatamento das paredes laterais, sendo a parte frontal (superior) mais estreita que as laterais. Às vezes, em algumas espécies, as nervuras medianas se prolongam em forma de apêndices, como em B. longicuspis. A nervação do cálice apresenta descontinuidade ao nível interespecífico, com algumas ressalvas e, os botões podem ser desde enérveos a estriados ou costados até estreitamente alados (Fig. 5).

O hipanto é internamente glabro, revestido na parte apical como em B. curvula (Fig. 13d), ou é totalmente revestido com indumento do tipo tomentoso, como por exemplo em $B$. bombaciflora e B. cupulata (Fig. 11d).

O cálice é composto por cinco segmentos calicinais unidos por coesão no botão ("laciniis cohaerentibus", Bongard, 1836) e, na antese, abrem-se através de fenda longitudinal inferior. Os segmentos calicinais são parcialmente unidos entre si, com diferentes níveis de coesão, formando de dois a quatro lobos, ou podem apresentar-se quase livres ou livres em $B$. cheilantha. Apresentam-se reflexos, ondulados e/ou espiralados, raramente são retos e eretos.

\section{Pétalas}

As pétalas são ungüiculadas e quase iguais, exceto pela superior que é geralmente menor em relação às laterais e inferiores. São totalmente brancas e, nunca com estrias de outras cores, caráter este, compartilhado com as demais espécies da seção Pauletia. A forma das pétalas têm valor taxonômico para agrupar séries e/ou identificar algumas espécies. As pétalas são lineares com razão comprimento/ largura entre 15 e 180, na maioria das espécies. Também, podem ser do tipo linear-lanceoladas ou linear-oblanceoladas, quando a razão comprimento/ largura se encontra entre 8,3 e 15 , por exemplo em $B$. brevipes e $B$. ungulata. Em $B$. cheilantha, que é a única espécie desta série a apresentar pétalas obovadas a razão comprimento/largura fica entre 2 e 8,3. Quanto ao indumento, as pétalas de algumas espécies podem se apresentar tomentosas a pilosas na face externa como, por exemplo, em $B$. longifolia. Este caráter, no entanto, não se mostrou consistente nas coleções estudadas. B. cheilantha e B. subclavata apresentam a face externa das pétalas coberta com tricomas glandulares naviculados, semelhantes àquelas encontradas nos ramos e folhas (ver ítem indumento). Estes tricomas glandulares também foram encontrados nas pétalas de $B$. acuruana, B. brevipes, B. longifolia.

\section{Androceu}

Os estames são basicamente dez, correspondentes a dois verticilos - o externo com estames ante-sépalos e, o interno com estames ante-pétalos. Os estames ante-sépalos têm filetes maiores e possuem anteras mais desenvolvidas e o verticilo ante-pétalo é formado por filetes menos robustos e por anteras menores. $\mathrm{O}$ estame mais externo é o inferior ante-sépalo e, o mais interno é o estame antepétalo superior. Os filetes estaminais permanecem unidos na base, formando internamente uma coluna irregular, a qual não apresenta solução de continuidade com o hipanto. A parte distal da coluna é irregular em altura e atinge menor amplitude de fusão no filete inferior. Há variação da coluna, ao nível específico, quanto ao grau de concrescimento (altura da coluna) e indumento. Em um grupo de espécies os estames são quase livres como em B. longifolia e B. holophylla. As anteras são lineares. Em alguns espécimes de $B$. cheilantha observou-se anteras loceladas, em outros, só havia vestígios dos locelos, na forma de septos tranversais. Entre os espécimes examinados foram detectados, em um mesmo 

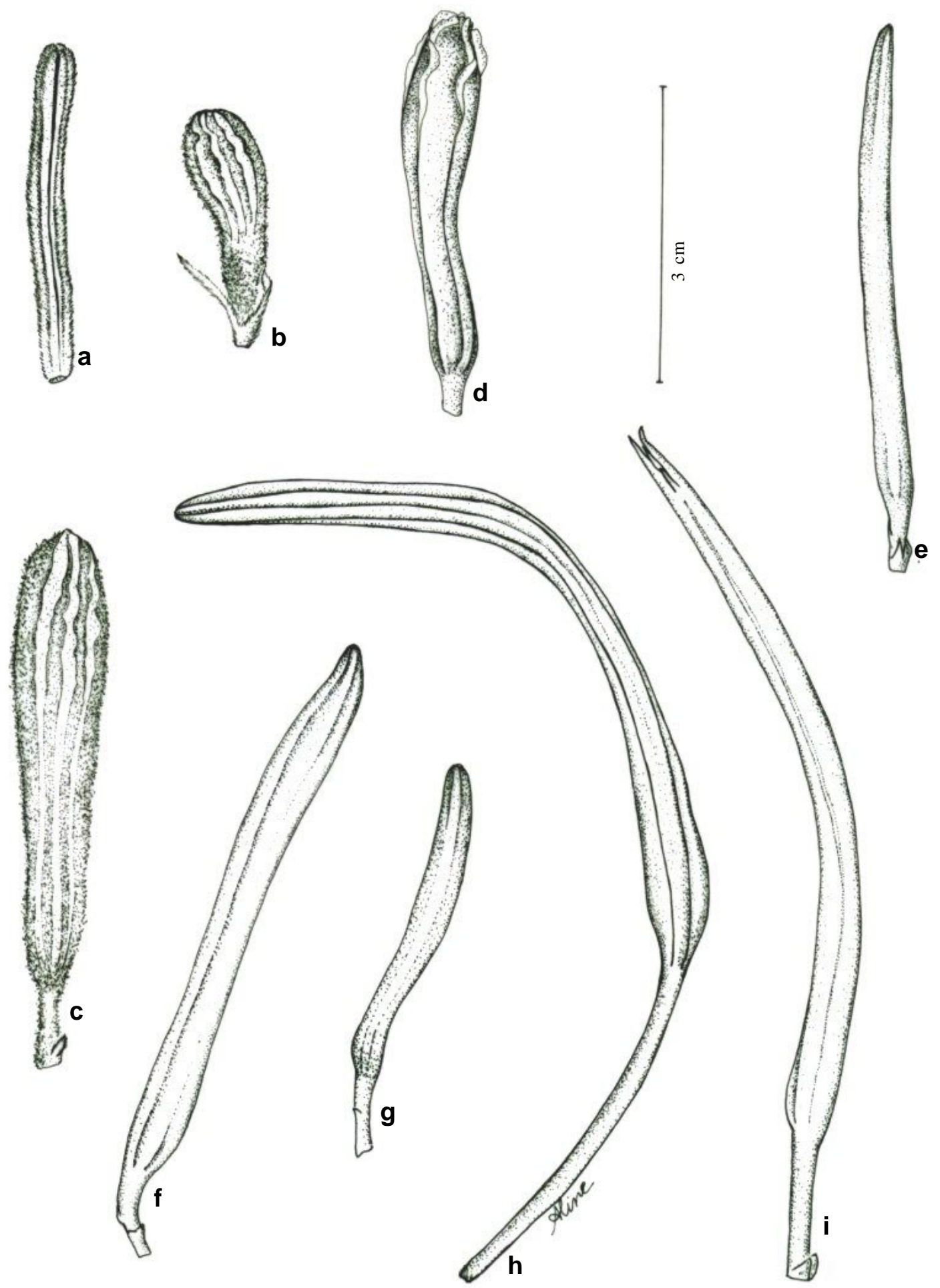

Figura 5 - Contorno do botão floral em Bauhinia ser. Cansenia: Linear-prismático: (a): B. caloneura (col. Malme 1138). Clavado (b,c,d): B. cheilantha (Riedel s/n):B; Bauhinia cheilantha (Malme s/n): c: B. subclavata (Alencar 244): d: Linear (e,h,i): B. conwayi (Williams 495): e; B. quartzitica (Silva 2082): h; B. membranacea (Gardner 3695): i. Clavado-acuminado: (f): B. grandifolia (Ducke s/n, RB 23419). Subclaviforme (g): B. ungulata (Vaz 1178). Desenho de Aline Souza de Oliveira, 2000. 
espécime, estames em número de 10 e 12, por isso número de estames férteis não é, aqui, considerado caráter em nível específico (ver discussão sob B. holophylla).

\section{Gineceu}

O ovário em Bauhinia ser. Cansenia, como nas demais séries da seção Pauletia, apresenta-se longamente estipitado. O comprimento total do estipe, na série Cansenia, vai de $1,2 \mathrm{~cm}$ em $B$. tenella a $16 \mathrm{~cm}$ em $B$. bombaciflora, correspondendo até a metade do comprimento total do gineceu. O estipe, assim como nas demais séries, é livre ou adnato à parede abaxial do hipanto, mas nunca adnato em mais do que um terço do comprimento total do estipe. O ovário é glabro apenas em $B$. dubia, B. quatzitica e B. smilacifolia. Nas demais espécies da série Cansenia o ovário apresenta-se indumentado, com maior ou menor concentração de tricomas glandulares naviculados. O estigma é clavado, a superfície estigmática fortemente assimétrica.

\section{Legume e sementes}

O legume na série Cansenia, assim como nas demais séries da seção Pauletia é longamente estipitado, plurisseminado e, tem deiscência elástica. As valvas são coriáceas e têm entre 8 e $29 \mathrm{~cm}$ de comprimento e o estípite varia, entre 1,5 e $6 \mathrm{~cm}$ de comprimento, exceto em $B$. bombaciflora com valvas e estípite bem maiores. O funículo apresenta dois lobos adnados na testa da semente, os quais podem ser filiformes, triangulares, emarginados ou lobados. As sementes apresentam hilo crescentiforme, uma característica exclusiva de toda a subtribo Bauhiniinae (Wunderlin et al., 1987) e, medem entre 5 e $15 \mathrm{~mm}$ de comprimento por 3,5 a $11 \mathrm{~mm}$ de largura. A lente pode ser indistinta ou proeminente e de coloração mais clara.

\section{Distribuição geográfica, padrões de distribuição e relações inter-específicas}

A área de maior diversidade de espécies para Bauhinia ser. Cansenia (35 espécies e 4 variedades, neste tratamento) é o planalto central brasileiro, na parte correspondente aos estados de Goiás, Tocantins e Distrito Federal, com 20 espécies. Em seguida, temos a região norte e nordeste cada uma com 13 espécies. Nos estados do Mato Grosso e Mato Grosso do Sul ocorrem 12 espécies. A região sudeste/ sul tem 10 espécies conhecidas (Figs. 20-28).

A análise da distribuição geográfica das espécies de Bauhinia sect. Cansenia no Brasil, revelou três padrões principais de distribuição, correspondentes aos biomas da floresta amazônica e da floresta atlântica (sensu Joly et al., 1999) e ao corredor seco formado pela caatinga e pelo cerrado ("dry diagonal of seasonal woodllands", sensu Prado \& Gibbs, 1993). No corredor seco, o habitat preferencial é a margem de floresta ao longo de rios e respectivas áreas de transição até áreas campestres lenhosas e áreas de contato caatinga/cerrado, especialmente em altitudes superiores a $800 \mathrm{~m}$ e também nas chapadas do nordeste.

Vinte e cinco espécies ocorrem no corredor seco, enquanto sete espécies são exclusivas da floresta amazônica e duas espécies preferem a floresta atlântica. Uma única espécie $B$. ungulata, apresentou ampla distribuição.

O padrão de distribuição amplo no corredor seco diagonal formado pela caatinga e cerrado foi observado para $B$. acuruana, B. brevipes, B. cupulata, B. cheilantha, B. curvula, B. dubia, B. dumosa, B. holophylla, B. rufa e B. subclavata, B. pulchella. Os endemismos ou áreas restritas de distribuição no corredor seco foram assinalados para $B$. burchelli, $B$. caloneura, B. campestris, B. bombaciflora, $B$. candelabriformis, $B$. gardneri, $B$. goyazensis, B. leptantha, B. malacotricha, $B$. malacotrichoides, B. smilacifolia $B$. tenella, B. membranacea e B. platyphylla.

$O$ padrão de distribuição correspondente ao bioma de floresta amazônica foi assinalado ра Bauhinia aureopunctata, $B$. cinnamomea, B. conwayi, B. longicuspis, $B$. grandifolia, $B$. longipedicellata e $B$. urocalyx. 
O padrão de distribuição correspondente ao bioma da floresta atlântica foi apresentado por Bauhinia fusconervis e B. longifolia.

Bauhinia ungulata é a espécie estudada com maior amplitude de distribuição, correndo na faixa neotropical, desde o México até São Paulo. No Brasil, a variedade típica ocorre na floresta amazônica e nas florestas refúgio do Ceará. B. ungulata var. cuyabensis ocorre em área correspondente ao corredor seco na região centro-oeste e sudeste. B. ungulata var. obtusifolia e B. ungulata var. parvifolia ocorrem em áreas restritas.

Em Bauhinia ser. Cansenia os padrões detectados podem ser associados com determinados complexos de espécies, supostamente aparentadas. De acordo com o conjunto de caracteres compartilhados pelos integrantes de um complexo e, ausentes das demais espécies, a saber - forma do botão, forma da pétala, coluna estaminal, tipo de indumento foliar e padrões de distribuição foram detectados sete complexos de espécies em Bauhinia ser. Cansenia. No entanto, restaram onze espécies insuficientemente conhecidas e indefinidas em relação aos complexos apontados (Tabela 1).

\section{Tratamento Taxonômico}

Bauhinia L., Sp. Pl. 374.1753.

Espécie-tipo: $B$. divaricata L.

Árvores pequenas a medianas até arbustos ou subarbustos com ramos inermes, aculeados ou espinescentes ou lianas até arbustos escandentes, com gavinhas. Nectários intra-estipulares presentes ou ausentes. Folhas inteiras, bilobadas a bifolioladas, 3-11-nervuras principais, estípulas caducas. Hipanto discóide ou cilíndrico; cálice campanulado, espatáceo ou com sépalas irregularmente conatas; estames livres ou conatos na base com apêndice ligulado desenvolvido a obsoleto; ovário séssil ou longamente estipitado, estigma de formas variadas. Legume lenhoso, coriáceo polispérmicos (3 ou mais sementes) ou membranáceo e, nesse caso com apenas 1-2 sementes. Hilo em forma de meia lua (crescêntico).
Cerca de 300 espécies, pantropical (Wunderlin et al., 1987).

Bauhinia sect. Pauletia (Cav.) DC, Prodr. 2:512.1825. Pauletia Cav., Icon. 5.5.1799; Espécie-tipo: Pauletia inermis Cav. [= Bauhinia ungulata L.], designado por De Wit (1956).

Arvoretas, em geral, 5-15 m, arbustos ou subarbustos com xilopódio, em geral, 0,5-2 m. Acúleos adpeciolares geminados presentes ou ausentes. Nectários extraflorais presentes ou ausentes. Folhas inteiras, bilobadas a bifo lioladas. Inflorescência racemiforme, em fascículos 2-(3-6)-floros ou flores 2-3geminadas sempre em ramos folhosos ou ainda, reunidas em pseudo-racemo terminal afilo; bráctea foliácea $1(-2)$ ou ausente, bráctea subtendente 1, bractéolas 2; botão desenvolvido, em geral, linear a clavado, às vezes fusiforme, 3-20,5 cm compr. Flores com hipanto cilíndrico a turbinado, às vezes linear ou piriforme, internamente tomentoso ou glabro; cálice na antese espatáceo e fenestrado na base ou fendido parcialmente em 2-5 lobos; pétalas 5, em geral lineares, unguiculadas, às vezes obovadas, sempre totalmente brancas, inclusive a pétala superior; estames férteis 10 ou 5 , alternados com 5 estames com anteras deficientes ou com 5 estaminódios; filetes conatos na base em coluna irregular; grãos de pólen, em geral muito grandes, com superfície reticulada ou microreticulada e processos supratectais gemóides ou com espinhos; ovário longamente estipitado; estipe parcialmente adnato à parede abaxial do hipanto a livre, estigma peltado-emarginado, bilobado ou assimetricamente clavado. Legume deiscente com valvas elásticas, ou modificado e indeiscente com valvas internamente divididas em septos tranversais (B. bauhinioides), externamente sem ou com sutura elevada $(B$. acuminata), plurisseminados, em geral com mais de cinco sementes. Sementes 5-13 x5-12 $\mathrm{mm}, 1-2 \mathrm{~mm}$ espessura.

Algumas espécies da seção Pauletia apresentam ramos flexíveis apoiantes e, às 
Tabela 1. Relações inter-específicas em Bauhinia ser. Cansenia e preferências por biomas.

\section{Complexo}

1. Bauhinia cheilantha

- B. subclavata - B.

acuruana

\section{Bauhinia dubia - B. longicuspis}

3. Bauhinia holophylla - B. longifolia - B. rufa

- B. aureopunctata B. longipedicellata

4. Bauhinia fusconervis - B. pulchella - B. dumosa - B. curvula B. tenellla $-B$. goyazensis - $B$. candelabriformis - $B$. malacotrichoides

\section{Bauhinia cupulata -} B.bombaciflora

6. B. ungulata $-B$. brevipes

7. B. cinnamomea - B. grandifolia

\section{Caracteres diagnósticos}

Estípulas semilunares, nem sempre presentes. Inflorescência tende a apresentar folhas intercaladas, reduzidas em tamanho, inflorescências parciais muitas vezes com três flores ou vestígios destas; botão largamente clavado, quando muito jovem, subgloboso, costado a estreitamente alado; pétalas obovadas a lanceoladas com margens fimbriadas e glandulosas no dorso; coluna estaminal internamente com apêndice laciniados nos bordos, hirsuta interna e externamente; anteras loceladas.

Botões lineares, os mais estreitos na série Cansenia, com ápice 5-cuspidado.Nectários cônico-ovóides. coluna estaminal internamente viloso-tomentosa a viloso-hirsuta, pétalas menos da metade do comprimento dos filetes.

Brácteas subtendentes lineares a linear-lanceoladas, quando presentes e desenvolvidas. Botões florais, os mais robustos da série Cansenia, às vezes pentagonais. Estipe velutino-tomentoso. Coluna estaminal reduzida a quase ausente e os estames quase livres, internamente muito glabra, inclusive o hipanto.

Estípulas rudimentares e submilimétricas. Botões cano-tomentelos, indumento com tricomas glandulares numerosos; coluna estaminal internamente seríceotomentosa e o indumento se prolonga nos filetes alternipétalos.

Inflorescência definida com ápice terminando em três flores, com aspecto paniculóide devido a reativação das gemas inferiores do pseudo-racemo. Hipanto internamente tomentoso da base até o ápice. Bractéolas cupuliformes

Estípulas oblanceoladas, nem sempre presentes ou bem desenvolvidas. Inflorescência alongadas, simultaneamente com muitos botões jovens (= tendência maior a um crescimento indefinido no ápice do pseudoracemo), pétalas linear-lanceoladas, coluna estaminal internamente com tufos de tricomas no bordos, externamente glabra. Flores com pedicelo $0,4-1,1 \mathrm{~cm}$ de comprimento.

Folha com nervura marginal proeminente da face inferior e com nervuras marginais retas, não formando alças; botão floral clavado-acuminado, pétala linearlanceoladas, longamente unguiculadas e de mesmo tamanho dos filetes, coluna estaminal internamente esparsamente pilosa.
Padrões de distribuição

Ampla no corredor seco: $B$. cheilantha.

Nordeste para norte: B. subclavata . Nordeste até Minas Gerais: $B$. acuruana.

Amazônia até Mato Grosso:

B.longicuspis .

Corredor seco no nordeste, até $10^{\circ}$

lat.S:B. dubia.

Bioma floresta Atlântica até o estado do Paraná: B. longifolia. Corredor seco: $B$. longifolia, $B$. rufa e $B$. holophylla. Bioma da floresta Amazônica: B. aureopunctata e $B$. longipedicellata.

Corredor seco: B. pulchella, B. curvula, B. dumosa, B. tenella. Endêmica de Juiz de Fora (MG) e Rio de Janeiro limítrofe: $B$.

fusconervis. Endêmicas do planalto central de Goiás (região da Chapada dos Veadeiros e adjacências): $B$. candelabriformis, B. goyazensis, $B$. malacotrichoides

Corredor seco: endêmicas em florestas ciliares, no estado do Tocantins e limítrofes Pará, Maranhão, Piauí, Goiás e Mato Grosso.

Desde o México até Amazônia periférica e corredor seco até $23^{\circ}$ lat. S. B. ungulata

Corredor seco, bioma do cerrado/ pantanal e transições: B. brevipes.

Amazônia central para Amazônia oeste. 


\section{CHAVE PARA SEÇÕES DO GÊNERO BAUHINIA OCORRENTES NO BRASIL}

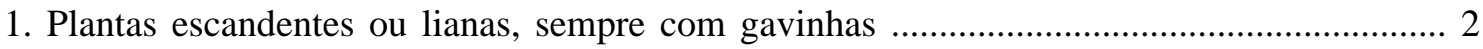

1. Plantas arbóreas ou arbustivas, se com ramos flexuosos, nunca com gavinhas ...................... 3

2. Ovário uni- biovulado, legume do tipo samaróide, cartáceo e indeiscente, pétalas subiguais Bauhinia sect. Schnella

2. Ovário com mais de quatro óvulos, legume lenhoso e com deiscência através de valvas elásticas, pétala superior distinta das demais Bauhinia sect. Caulotretus

3. Cálice campanulado, hipanto discóide, ramos ocasionalmente com espinhos, nunca com acúleos ou nectários extraflorais Bauhinia sect. Benthamia

3. Cálice espatáceo ou não, nesse caso com lobos livres ou parcialmente 2-5 unidos no ápice e se abrindo em direçäo à base, hipanto urceolado, turbinado, linear, piriforme ou cilíndrico, com acúleos adpeciolares ou inermes, nunca com espinhos

4. Estames férteis, três Bauhinia sect. Bauhinia

4. Estames férteis, cinco a dez 5

5. Flores delicadas, botões elipsoides ou ovóides até $1,5 \mathrm{~cm}$ compr.; hipanto urceolado; pétalas até $2 \times 0,7 \mathrm{~cm}$, a superior dimórfica Bauhinia sect. Amaria

5. Flores vigorosas, botões tubulosos e fusiformes a clavados, 3-18 cm compr.; hipanto de outros tipos; pétalas (2,5-3-)4-15x0,7-2,6 cm, quase iguais Bauhinia sect. Pauletia

vezes, podem apresentar-se na forma de arbusto escandente ou lianas. No entanto, essas espécies assim como as demais do subgênero Bauhinia, nunca apresentam-se com gavinhas, como no subgênero Phanera. As plântulas estudadas nunca apresentam germinação criptógea e eófilos opostos, como nas espécies estudadas do subgênero Phanera, e sim germinação não criptógea e eófilos alternos.

Bauhinia ser. Cansenia (Raf.) Wunderlin, Larsen \& Larsen, Biol. Skrif. 28: 12. 1987, emendavit Vaz \& Tozzi (2003). Basiônimo: Cansenia Raf. Espécie-tipo: Cansenia ungulata (L.) Raf. [= Bauhinia ungulata L.], lectótipo designado por Wunderlin (1976).

Arvoretas ou arbustos multicaules, ou ainda subarbustos xilopodíferos com ramos inermes. Nectários extraflorais presentes, cônicos a subulados, 0,5-1,5 mm compr. Folhas inteiras, bilobadas a bifolioladas, às vezes inteiras e bilobadas no mesmo indivíduo, 0,9-20x0,5-17 $\mathrm{cm}$. Pseudo-racemo terminal áfilo, brácteas foliáceas presentes, inflorescências parciais 13- floras, eixo parcial ausente; botão floral linear, subclavado, subclavado-pentagonal, clavado ou clavadoacuminado, liso a estriado ou costado até alado, ápice nunca corniculado ou cristado, às vezes cuspidado (B. longicuspis), anteantese 3-20,5 cm compr.; hipanto cilíndrico, internamente tomentoso ou glabro; cálice na antese fendido em 2-5 lobos parcialmente unidos no ápice ou livres, nunca espatáceo; pétalas lineares, linear-lanceoladas, linearoblanceoladas ou obovadas (B. cheilantha), unguiculadas, $1,3-4,5(-8) \times 0,1-0,3-(2,5) \mathrm{cm}$, glabras ou pilosas externamente, nunca lanosas externamente e na unha; 10 estames férteis, estaminódios ausentes, filetes conatos na base formando coluna irregular obsoleta até altura máxima de $8 \mathrm{~mm}$, internamente com apêndice ligular laciniado (B. cheilantha), obsoleto a ausente, interna e externamente com indumento variado ou glabra; grãos de pólen 3-colpados, angulo-aperturados, raramente com 4 colpos, colpos elíticos, com membrana do colpo evidente, com processos supratectais gemóides; estipe (1,2-)2,5-5(-16) cm, livre, estigma assimetricamente clavado. Legume estreitamente oblongo, valvas 8-20(-40)x1-2(-2,7) $\mathrm{cm}$, internamente não divididas em compartimentos, externamente sem sutura elevada; semente sem apêndice unciforme encobrindo o hilo, sem linhas fraturais e não 


\section{CHAVES PARA AS SÉRIES DE BAUHINIA SECT. PAULETIA*}

1. Legume indeiscente; pétalas externamente lanosas, inclusive na unha ........ Bauhinia ser Perlebia

1. Legume deiscente; pétalas nunca lanosas

2. Estames férteis 5 (ante-sépalos), alternados com 5 filetes reduzidos (ante-pétalos), estes com anteras deficientes ou reduzidos a estaminódios filiformes .......... Bauhinia ser. Pentandrae

2. Estames férteis 10, filetes com tamanho desiguais, porém todos com anteras férteis ............. 3

3. Inflorescencias racemiformes, em geral, 7-15 flores; pólen inaperturado; pétalas não unguiculadas

Bauhinia ser. Acuminatae

3. Inflorescências fasciculiformes com 2-6 flores, ou compostas de pares sucessivos de flores geminadas em ramos folhosos, ou ainda, um pseudo-racemo áfilo terminal; pólen 3-6 aperturado, pétalas unguiculadas 4

4. Plantas inermes, nectários extraflorais presentes, às vezes rudimentares; pétalas lineares a linearlanceoladas, exceto em $B$. cheilantha e então, flabelado-venosas; inflorescência do tipo pseudoracemo terminal áfilo 5

4. Plantas aculeadas, acúleos adpeciolares, nectários extraflorais ausentes; pétalas oblanceoladas a obovado-espatuladas; inflorescências parciais secundas, em ramos folhosos .. Bauhinia ser. Aculeatae

5. Estigma bilobado; legume lenhoso, obovado, 2,5-3,8 cm de largura; grão de pólen porado, sexina com processos supratectais espinescentes .... Bauhinia ser. Ariaria

5. Estigma clavado; legume coriáceo e estreito oblongo a linear, até $2,5-3 \mathrm{~cm}$ de largura; grão de pólen colporado ou colpado, sexina, em geral, com processos supratectais gemóides

Bauhinia ser. Cansenia

*Vaz (2001, parte 2) apresentou uma sinopse de Bauhinia sect. Pauletia, com descrição das séries Aculeatae, Acuminatae, Ariaria, Pentandrae e Perlebia e chave para as espécies ocorrentes no Brasil.

\section{CHAVE PARA A IDENTIFICAÇÃO DAS ESPÉCIES DE BAUHINIA SER. CANSENIA OCORRENTES NOS ESTADOS DO ACRE, AMAPÁ, AMAZONAS, PARÁ, RONDONIA, RORAIMA}

1. Inflorescência com eixo sucessivamente dístico, robusto, viloso-tomentoso, inflorescências parciais reduzidas a uma única flor; botão até $20,5 \mathrm{~cm}$ compr. B. bombaciflora

1. Inflorescência de outros tipos, botão menor que $15 \mathrm{~cm}$ compr. 2

2. Botão floral acuminado ou caudado; pétalas longamente-unguiculadas, $6-7,5 \times 0,2-0,3 \mathrm{~cm}$ (desconhecidas em B. urocalyx) 3

2. Botão floral nunca acuminado ou caudado; pétalas nunca longamente unguiculadas, $1,3-4 \times 0,08$ $0,1 \mathrm{~cm}$ B. grandifolia

3. Indumento da inflorescência hirsuto 5

3. Indumento da inflorescência de outros tipos, porém nunca hirsuto ........................................ 4

4. Folhas bilobadas, botão floral clavado, com ápice caudado ................................. B. urocalyx

4. Folhas inteiras, botão floral clavado, com ápice acuminado ........................... B. cinnamomea

5. Coluna estaminal totalmente glabra, interna- e externamente 6

5. Coluna estaminal irregularmente esparso-pilosa a rufo-vilosa internamente ou hirsuta até velutinotomentosa na porção distal ou nos bordos 8

6. Folhas bilobadas, lobos concrescidos em $1 / 3$ até $2 / 3$ do comprimento .................. B. longifolia

6. Folhas inteiras a curtamente bilobadas, lobos desde 4/5 a 14/15 concrescidos 7

7. Botão floral 5-costado; folhas 7-nérveas, face inferior tomentela B. aureopunctata

7. Botão floral 15-costado, folhas 9-11-nérveas, face inferior vilosa B. longipedicellata 
8. Coluna estaminal com bordos fimbriados e tufos de tricomas alternados; pétalas linear-lanceoladas

B. ungulata

8. Coluna estaminal sem bordos fimbriados ou tufos de tricomas; pétalas lineares 9

9. Ovário e valvas do legume glabros B. dubia

9. Ovário tomentelo a velutino-tomentoso; valvas do legume pubérulas 10

10. Lâmina foliar 1 - 5,1 x 1,2 - $6 \mathrm{~cm}$; ovário com tricomas glandulares 11

10. Lâmina foliar 9 - 26 × $5-15,5 \mathrm{~cm}$; ovário sem tricomas glandulares 12

11. Folhas bifolioladas, folíolos incurvo-oblongos B. curvula

11. Folhas bilobadas, lobos ovado-elíticos a obovados ou suborbiculados B. pulchella

12. Folhas inteiras, se bilobadas os lobos concrescidos em $2 / 3$ do comprimento ou mais;eixo da inflorescência pubérulo B. longicuspis

12. Folhas bilobadas, os lobos concrescidos em até $1 / 3$ do comprimento total; eixo da inflorescência tomentoso a velutino

B. conwayi

\section{CHAVE PARA A IDENTIFICAÇÃO DAS ESPÉCIES DE BAUHINIA SER. CANSENIA OCORRENTES NOS ESTADOS DE ALAGOAS, BAHIA, CEARÁ, MARANHÃO, PARAÍbA, PERNAMBUCO, PIAUÍ, RIO GRANDE DO NORTE E SERGIPE}

1. Pétalas obovado-oblongas a estreito-obovadas, obtusas, relação comprimento/largura igual ou menor que 8,3 ; anteras loceladas ou não; estípulas semilunares, às vezes ausentes ... B. cheilantha

1. Pétalas lineares, linear-oblanceoladas a linear-lanceoladas, relação comprimento/ largura igual (B. brevipes) ou maior que 8,3; anteras nunca loceladas; estípulas quando presentes, de outras

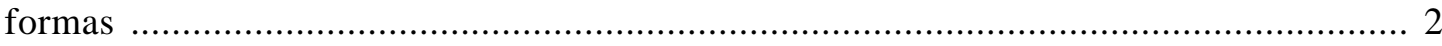

2. Folhas inteiras, acuminadas a emarginadas, às vezes curtamente bilobadas e amplamente ovadas ...... 3

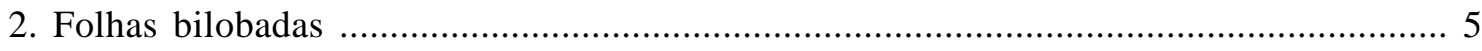

3. Face inferior da folha vilosa ou hirsútula; pétalas linear-oblanceoladas com tricomas glandulares na superfície externa; botões clavados B. acuruana

3. Face inferior da folha pubérula até glabra, pétalas lineares, sem tricomas glandulares; botões lineares

4. Folha 5-7-nérvea, pecíolo $0,5-1,5 \mathrm{~cm}$ compr. ...................................................... B. dubia

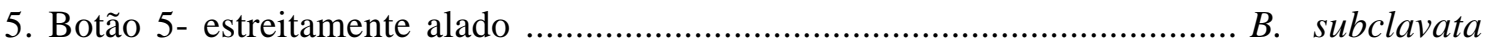

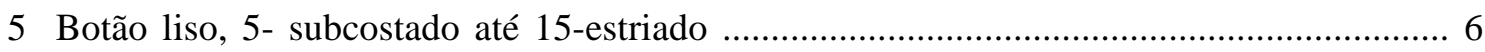

6. Hipanto velutino-tomentoso internamente, bractéolas cupuliformes ..................................... 7

6. Hipanto irregularmente tomentoso apenas na porção distal ou totalmente glabro, brácteolas não

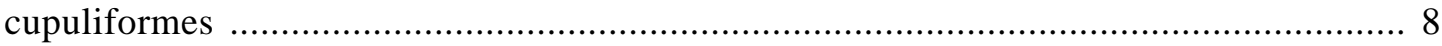

7. Botões 20x1-1,4 cm; valvas do legume $35-40 \times 2,5-3 \mathrm{~cm}$............................ B. bombaciflora

7. Botões 8-10x0,4-0,7 cm ; valvas do legume 12-18x1,1-2 cm ............................. B. cupulata

8. Coluna estaminal totalmente glabra, interna- e externamente ........................... B. longifolia

8. Coluna estaminal tomentosa internamente, em toda sua extensão, ou apenas irregularmente esparsopilosa a rufo-vilosa, hirsuta até velutino-tomentosa na porção distal ou nos bordos ...................... 9

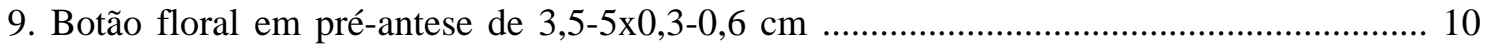

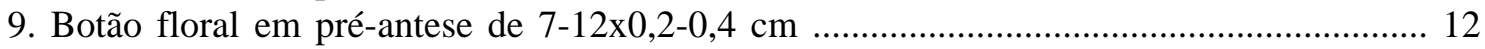

10. Folhas bifolioladas, cada folíolo $0,8-2 \times 0,4-1 \mathrm{~cm}$...................................................... B. tenella

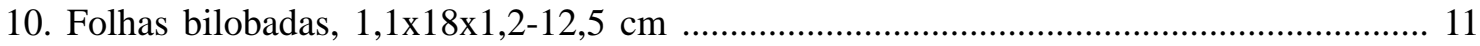

11. Face inferior da folha vilosa a hirsútula ........................................................ B. brevipes

11. Face inferior da folha pubescente a tomentela .............................................. B. ungulata

Rodriguésia 54 (83): 55-143. 2003 
12. Face inferior da folha tomentoso-hirsútula B. dumosa var. dumosa

12. Face inferior da folha pubescente B. pulchella

\section{CHAVE PARA A IDENTIFICAÇÃO DAS ESPÉCIES DE BAUHINIA DA SER. CANSENIA OCORRENTES NOS ESTADOS DE ESPÍRITO SANTO, MINAS GERAIS, PARANÁ, RIO DE JANEIRO E SÃO PAULO}

1. Pétalas obovado-oblongas a estreito-obovadas, relação comprimento/largura igual ou menor que $8,3 \mathrm{~cm}$; anteras loceladas ou não; estípulas semilunares, às vezes ausentes B. cheilantha

1. Pétalas lineares, linear-oblanceoladas a linear-lanceoladas, relação comprimento/largura maior que $8,3 \mathrm{~cm}$; anteras não loceladas; estípulas, quando presentes, de outras formas

2. Folhas inteiras, às vezes sub-bilobadas mas, ainda ovado-lanceoladas a sub-orbiculadas .......... 3

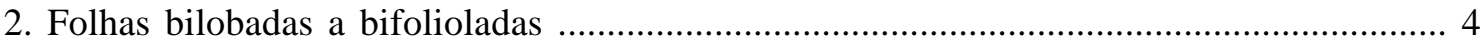

3. Pétalas linear-oblanceoladas; coluna estaminal interna e externamente hirsútula a pilosa

3. Pétalas lineares; coluna estaminal glabra interna e externamente B. holophylla

4. Hipanto irregularmente tomentoso, apenas na porção distal interna, coluna estaminal sem bordos fimbriados 5

4. Hipanto na parte interna glabro ou com tufos de tricomas, apenas nos bordos fimbriados da coluna estaminal

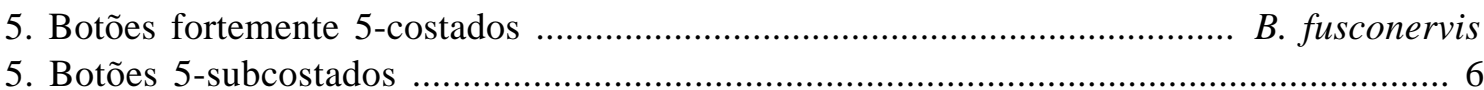

6. Folhas bifolioladas, folíolos incurvo-oblongos ................................................. B. curvula

6. Folhas bilobadas, lobos ovado-elíticos a obovados ou suborbiculados ................... B. pulchella

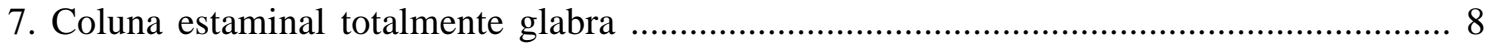

7. Coluna estaminal com bordos fimbriados com tufos de tricomas ....................................... 9

8. Folhas 4-17x 1,5-12,5 cm, lobos agudos a obtusiuculos, tênue-cartáceos a sub-coriáceos; estípulas ovadas a ovado-lanceoladas

B. longifolia

8. Folhas 6-10,8x5,4-10 cm, lobos obtusos a arredondados ou subtruncados, coriáceos; estípulas oblongas, sub-agudas a lineares B. rufa

9. Face inferior da folha vilosa a hirsútula; estípulas, quando presentes, lineares B. brevipes

9. Face inferior da folha pubescente a tomentela; estípulas, quando presentes, ovado-lanceoladas, oblanceo-ladas a falcado-oblongas

B. ungulata

\section{CHAVE PARA AS ESPÉCIES DE BAUHINIA SER. CANSENIA DOS ESTADOS DE GOIÁS, TOCANTINS E DO DISTRITO FEDERAL}

1. Plantas com ramos hirsutos; botão 5-alado B.burchelli

1. Plantas com ramos glabros ou com outros tipos de indumento; botão liso a costado ou estriado ... 2

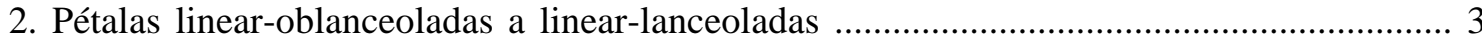

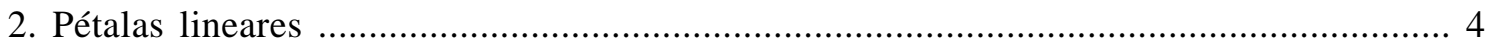

3. Face inferior da folha vilosa a hirsútula; estípulas, quando presentes, lineares ............. B. brevipes

3. Face inferior da folha pubescente a tomentela; estípulas, quando presentes, ovado-lanceoladas, oblanceoladas a falcado-oblongas B. ungulata

4. Inflorescência longamente pedunculada, pedúnculo 7,5-16 cm compr.; entrenó foliáceo distal 5$13 \mathrm{~cm}$ compr. 
4. Inflorescência curtamente pedunculada, pedúnculo menor que $7 \mathrm{~cm}$ de compr; entrenó distal igual ou menor que $7 \mathrm{~cm}$ compr.

5. Folha bilobada, sub-orbiculada B. gardneri

5. Folha bifoliolada, folíolos elíticos perorbiculados ou reniformes B. malacotrichoides

6. Hipanto velutino-tomentoso internamente; bractéolas cupuliformes 7

6. Hipanto tomentoso apenas na porção distal interna ou totalmente glabro; bractéolas não cupuliformes 8

7. Inflorescência com eixo sucessivamente dístico, robusto, viloso-tomentoso, inflorescências parciais reduzidas a uma única flor; botão até 20,5 compr.

B. bombaciflora

7. Inflorescência geralmente ramificada com aspecto paniculado; botão até $8 \mathrm{ou} 10 \mathrm{~cm}$ compr

B. cupulata

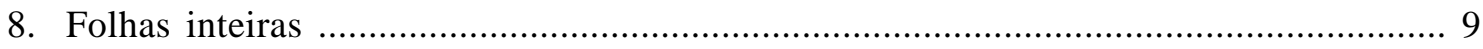

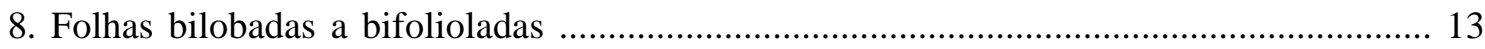

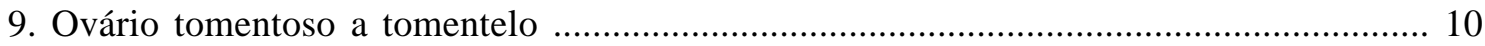

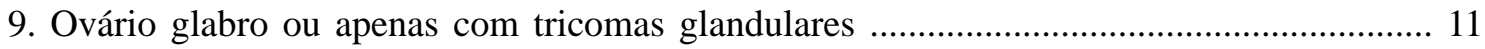

10. Botão floral pentagonal e robusto; face inferior da folha curto-tomentosa a vilosa ....... B. holophylla

10. Botão floral linear e delgado, face inferior da folha pubérula .......................................... 12

11. Contorno da folha ovado-lanceolado, ápice acuminado; valvas do legume púberulas ......B. longicuspis

11. Contorno da folha amplo, largamente ovado; ápice obtuso, muito curtamente bilobado; valvas do legume viloso-tomentosas a esparso- vilosas

B. membranacea

12. Folha cordado-auriculada, nervura marginal elevado-proeminete

B. smilacifolia

12. Folha cordada a subtruncada, nervura marginal não elevada

B. dubia

13. Coluna estaminal totalmente glabra interna- e externamente 14

13. Coluna estaminal internamente tomentosa em toda sua extensão, sem solução de continuidade com o indumento da região distal do hipanto ou, apenas, irregularmente esparso-pilosa a rufovilosa, hirsuta até velutino-tomentosa

14. Folhas curtamente bilobadas, lobos concrescidos em até $4 / 5$ do compr., geralmente coriáceas, lobos obtusos a arredondados ou subtruncados; estípulas oblongas sub-agudas a lineares B. rufa

14. Folhas bilobadas, lobos concrescidos em $1 / 3$ até $2 / 3$ do comprimento, geralmente cartáceas a subcoriáceas, lobos agudos a obtusiúculos; estípulas ovadas a ovadolanceoladas B. longifolia

15. Ramos e eixo da inflorescência, pecíolo e folhas inteiramente glabros e glaucescentes

15. Ramos e eixo da inflorescência e folhas com indumento
16. Botão pentagonal, robusto; coluna estaminal internamente B. platyphylla pilosa; entrenó distal no ramo ca. $5,5 \mathrm{~cm}$ compr. 16

16. Botão não pentagonal; coluna estaminal internamente seríceo-tomentosa e ex ternamente glabra a levemente pilosa; entrenó distal do ramo igual ou menor que $5 \mathrm{~cm}$.

17. Ápice do botão 5-cuspidado, às vezes, setas precocemente caducas ou rudimentares, folhas 14,7-16x12-3 cm, tênue-cartáceas

B. membranacea

17. Ápice do botão reentrante, nunca setáceo; folhas $0,8-6$ x 0,6-6 cm, cartáceas a coriáceas (se tênue-cartáceas, então B. pulchella) 18

18. Inflorescência 5-6 cm compr., sub-corimbiforme B. candelabriformis

18. Inflorescência maior que $7 \mathrm{~cm}$ compr., racemiforme 19

19. Face inferior da folha tomentoso-hirsútula a viscídula B. dumosa

19. Face inferior da folha com indumento apresso, tomentelo a pubescente 20

20. Folhas bilobadas, os lobos concrescidos em mais do que $2 / 3$ do comprimento total ............ B. pulchella 20. Folhas bifolioladas, às vezes, os folíolos concrescidos em ca. de $2 / 3$ do comprimento total ......... 21 
21. Folíolos ou lobos sub-reniformes a ovado-elíticos

B. goyazensis

21. Folíolos incurvo-oblongos 22

22. Folíolos $0,8-2 \times 0,4-1 \mathrm{~cm}$; pedicelos $0,5-0,8 \mathrm{~cm}$ compr., hipanto $0,5 \mathrm{~cm}$ compr. .......... B. tenella

22. Folíolos 1,5 - 4,2 x 0,6-1,8 cm; pedicelos 1 -3 cm compr; hipanto 0,8 - 1,5 cm compr. .... B. curvula

\section{CHAVE PARA IDENTIFICAÇÃO DE BAUHINIA SER. CANSENIA OCORRENTES NOS ESTADOS DE MATO GROSSO E MATO GROSSO DO SUL}

1. Eixo da inflorescência hirsuto

B. caloneura

1. Eixo da inflorescência com outros tipos de indumento 2

2. Pétalas obovado-oblongas a estreito-obovadas, relação comprimento/largura igual ou menor que 8,3 ; anteras loceladas ou não; estípulas semilunares, às vezes, reduzidas até rudimentares ..

B. cheilantha

2. Pétalas lineares, linear-oblanceoladas a linear-lanceoladas, relação comprimento/largura maior que 8,3; anteras nunca loceladas, estípulas desenvolvidas, quando presentes, de outras formas ........... 3

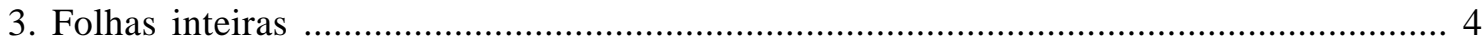

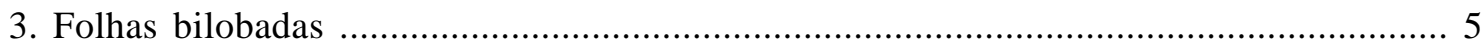

4. Face inferior da folha pubérula; botão linear ; filetes $5,5-8 \mathrm{~cm}$ de compr.; coluna staminal internamente viloso-tomentosa .............................................................. B. longicuspis

4. Face inferior da folha curto-tomentosa a vilosa; botão pentagonal; filetes $3,5-4 \mathrm{~cm}$ compr.; coluna estaminal internamente glabra B. holophylla

5. Inflorescência longamente pedunculada, pedúnculo $19-24 \mathrm{~cm}$ compr. B. campestris

5. Inflorescência curtamente pedunculada, pedúnculo até ca. $3 \mathrm{~cm}$ compr. ............................ 6

6. Hipanto velutino-tomentoso internamente; bractéolas cupuliformes ....................... B. cupulata

6. Hipanto irregularmente tomentoso apenas na porção distal, internamente ou totalmente glabro; bractéolas não cupuliformes

7. Coluna estaminal totalmente glabra, interna e externamente .............................. B. longifolia

7. Coluna estaminal internamente tomentosa em toda sua extensão sem solução de continuidade com o indumento da região apical do hipanto ou apenas irregularmente esparso-pilosa a rufo-

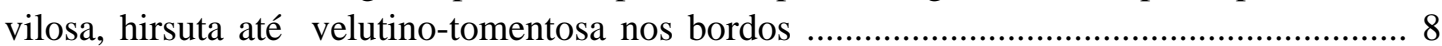

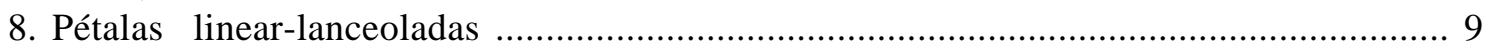

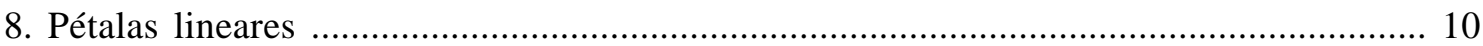

9. Face inferior da folha vilosa a hirsútula ............................................................. B. brevipes

9. Face inferior da folha pubescente a tomentela ................................................. B. ungulata

10. Folha curtamente bilobada, ovário pubérulo .................................................... B. leptantha

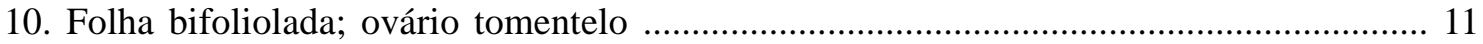

11. Folhas bifolioladas, folíolos incurvo-oblongos ................................................. B. curvula

11. Folhas bilobadas, lobos ovado-elíticos a obovados ou suborbiculados ................. B. pulchella

\section{Descrição das espécies de Bauhinia ser. Cansenia}

1. Bauhinia acuruana Moricand, Pl. nouv. Amér. 6:77, tab. 5. 1840. - Tipo. Brasil. Bahia. Serra Açuruá, 1839 (fl), Blanchet 2825 (holótipo G; isótipos NY!, P!, fotografia dos isótipos $\mathrm{RB} !)$.
Bauhinia acuruana var. nitida Benth., Fl. bras.15(2): 187. 1870. - Tipo: Brasil. Minas Gerais: Claussen (síntipo, não localizado); S. Romão, s/data (fr), Gardner 4536 (síntipo K, fotografia RB!; OXF!). Sin. nov.

Bauhinia lamprophylla Harms, Bot. Jahrb. 33(72):22. 1903. - Tipo: Brasil, Goiás: 


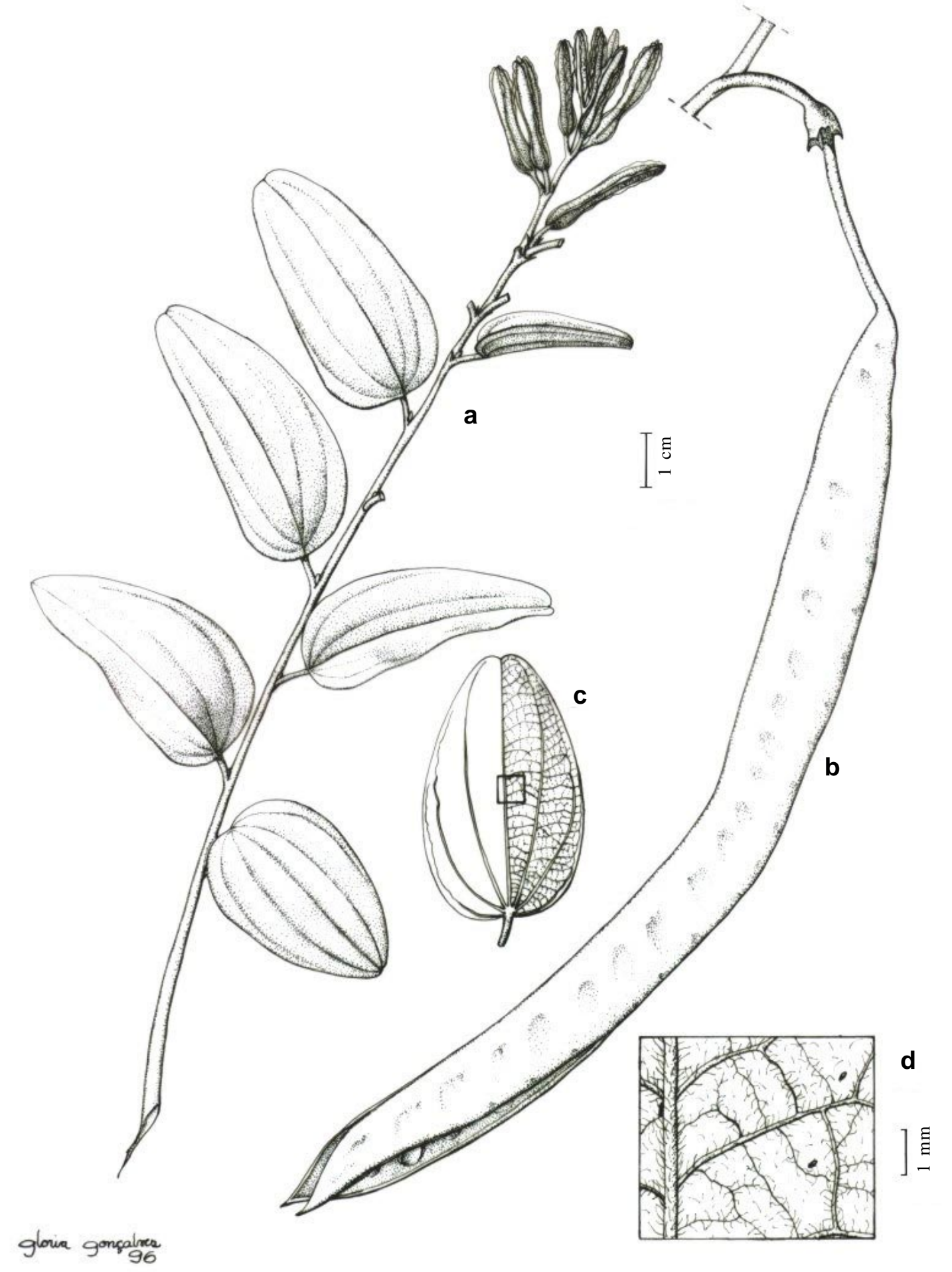

Figura 6 - Bauhinia acuruana (a, c e d, Araujo s/n RB 296136; b, Heringer, 760): a, ramo florífero; b, fruto; c, contorno foliar; d, detalhe do indumento na face inferior da folha. Desenho de G. Gonçalves, 1996. 

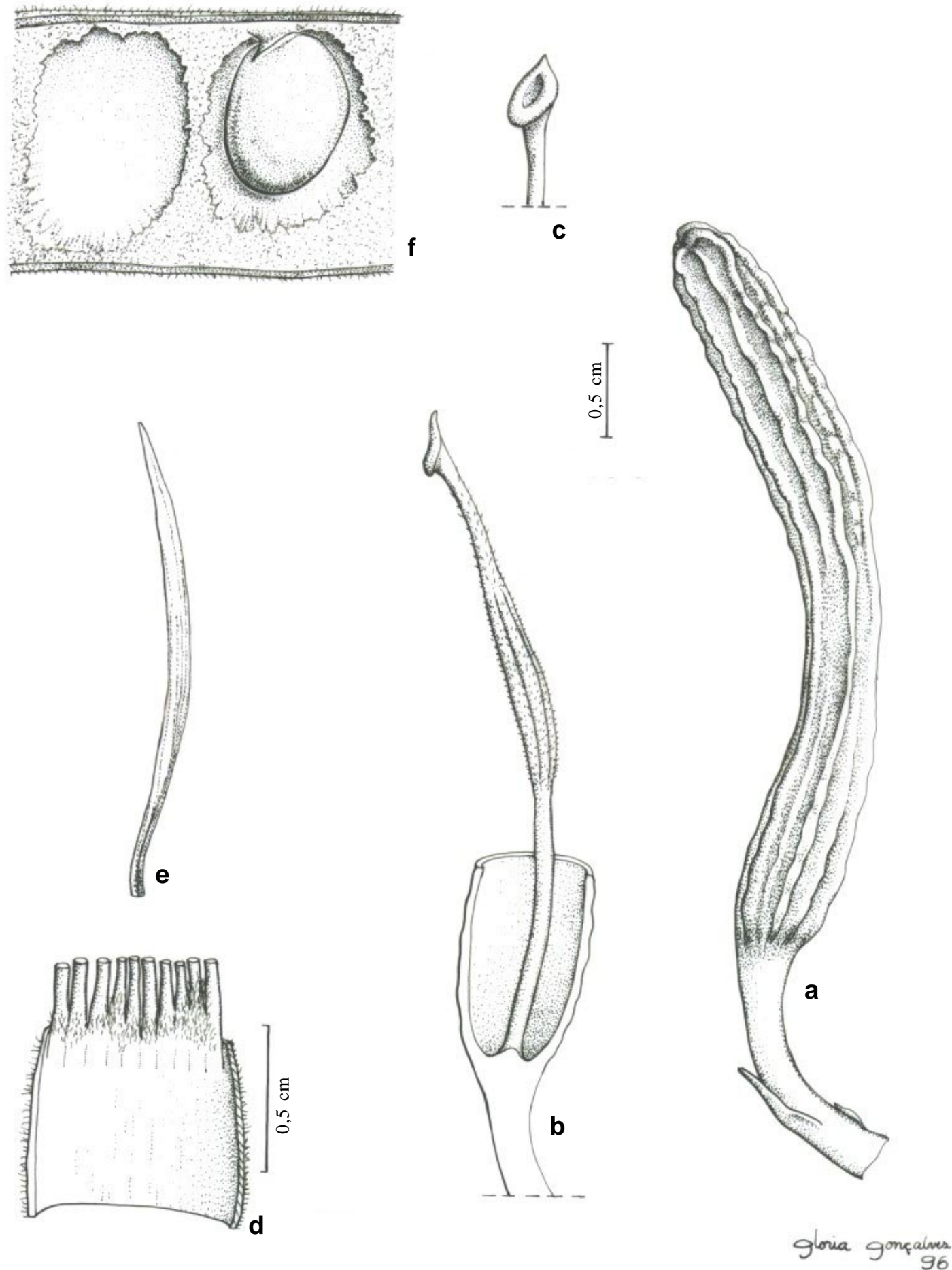

Figura 7 - Bauhinia acuruana (a, Salgado 21; b, c, e, Carvalho 17; d, Miranda 40; f, Alencar 245): a, botão; b, gineceu, veja inserção do ginóforo no fundo do hipanto; c, detalhe do estigma; d, coluna estaminal em continuidade com a face interna do hipanto; e, pétala na antese; f, detalhe da valva com semente. Desenho de G. Gonçalves, 1996. 
"Serra dos Cristais dans le campo". Glaziou 21008 (fl), 15.set.1895, (holótipo B/ herbarium Ign Urban, destruído; isótipo C!, fotografia do holótipo RB! ex F negativo 1592). Sin. nov.

Figuras 6 e 7.

Subarbusto ou arbusto. Entrenó distal do ramo $1,5-3 \mathrm{~cm}$ comprimento. Folhas inteiras, lâmina 3,3-10 x 1,7-6,5 cm, cartácea a coriácea, ovado-oblonga a cordado-ovada, base cordada a emarginada, ápice mais ou menos agudo a obtuso até arredondado (ápice dobrado nos espécimes herborizados), 5-7-nérvea, nervura marginal não elevado-proeminente, nem infranerviforme, nem aplanada; face superior vilosa, glabrescente até glabra, nervuras terciárias e quaternárias bastante impressas dando à superfície um aspecto rugoso, face inferior vilosa ou hirsútula até quase glabra, inclusive na região das nervuras primárias, tricomas glandulares geralmente abundantes, nervuras primárias proeminentes, secundárias e terciárias mais ou menos proeminentes; pecíolo $0,4-0,6(-1,5) \mathrm{cm}$ compr., delgado, viloso a hirsútulo. Estípulas lineares a lanceoladas, 2$7 \mathrm{~mm}$ compr.; nectários extraflorais rudimentares, ca.0,5 $\mathrm{mm}$ compr., geralmente encobertos pelas estípulas. Inflorescência até $25 \mathrm{~cm}$ compr., curto-pedunculada; pedúnculo 1-2,5 cm compr., eixo racemiforme, tomentoso a viloso-tomentoso; inflorescências parciais 23-floras; brácteas foliáceas com lâmina até $3,2 \times 1,2 \mathrm{~cm}$, estreito-lanceoladas, na parte proximal da inflorescência até brácteas foliáceas mucroniformes lineares a lanceoladas, nectários rudimentares, não visíveis. Botões até $5 \times 0,5 \mathrm{~cm}$ na antese, clavados, ápice 5-alado, 5costados, viloso-tomentosos a pubérulos, tricomas glandulares geralmente numerosos. Flores com pedicelo 1-2 cm compr., bractéolas lineares, hipanto cilíndrico, 1-1,8x0,6 cm, internamente glabro; cálice fendido na antese em 2-5 lobos reflexos, ondulados a retorcidos, 3-4 cm compr; pétalas linear-oblanceoladas, 1$2(-3,5) \times 0,15-0,3(0,5) \mathrm{cm}$, externamente glabras, rara-mente com tricomas glandulares esparsos; estaminódios 0 , estames 10 , anteras iguais, lineares, não loceladas, filetes 1,5-2,7 cm compr., filetes alternipétalos, glabros ou esparso-pilosos externamente na base; coluna estaminal presente, 2-3 mm de altura máxima, apêndice ligular obsoleto, internamente hirsuta nos bordos, externamente hirsútula; gineceu $5,5 \mathrm{~cm}$ compr., estigma obliquo-clavado, ovário tomentoso-hirsútulo, estipe $2,3 \mathrm{~cm}$ compr., esparsamente piloso. Legume deiscente, valvas 9-17x1,5-1,6(-2 )cm, vilósulo, estipe 2,5-3-(-4) $\mathrm{cm}$ compr.; lobos funiculares uncinado-lobados. Sementes não vistas.

Ocorre no Brasil, estados Bahia, Ceará, Goiás, Maranhão, Minas Gerais, Pernambuco e Piauí (Fig. 20). Geralmente é encontrada em áreas montanhosas e/ou com altitudes de 600 até 1.100 metros. Cresce em solo pedregoso ou arenoso ou algum tanto argiloso, na orla de floresta estacional caducifolia, cerradão, caatinga, cerrado, carrasco, transição caatinga/ cerrado, cerrado/floresta estacional, e finalmente nos campos gerais e campo rupestre. Folhas IBGE (1960) SB-23, SB-24, SC-23, SC24 SD-23, SD-24 (Bahia, Ceará, Maranhão, Pernambuco e Piauí); SD-23, SE-23, SE-24 (Minas Gerais e Goiás).

Espécimes com raque plenamente desenvolvida e simultaneamente com botões, flores e frutos em inicio de frutificação foram coletados de dezembro a março. Plena frutificação (só frutos): abril, maio, junho, julho a setembro.

O isótipo examinado de Bauhinia acuruana (Blanchet 2825) apresenta botões jovens fortemente 5-costados, estreitamente alados em direção ao ápice, folhas geralmente vilosas na face superior, valvas $14-15,5 \times 1,5 \mathrm{~cm}$. O síntipo examinado de B. acuruana var. nitida (Gardner 4536) não apresenta flores ou botões, porém as folhas são idênticas às dos tipos de $B$. acuruana, exceto pelo fato de que nunca são vilosas na face superior. Os espécimes examinados mostraram que os dados de dimensões dos frutos, não representam um caráter taxonômico, variando inclusive em um mesmo espécime. Os caracteres tipo de indumento da inflorescência e nervuras do botão não puderam ser correlacionados com 
nenhum outro caráter e, por si só se mostraram insuficientes para delimitar variedade.

Harms (1903) não citou as afinidades entre B. lamprophylla e B. acuruana. O espécime tipo da primeira difere do de $B$. acuruana s.str. pelos seguintes caracteres: ramos pubérulos a glabrescentes, folhas suborbiculares ou ovado-orbiculares ou ovadas, mais largas ou tão largas quanto longas, ápice arredondado (dobrado nos espécimes herborizados), emarginado ou curtamente lobulado, face superior nítida e glabra, inferior subglabra ou pubérula nos nervos, botões levemente 5costados, pétalas até $3,5 \times$ ca. $0,5 \mathrm{~cm}$.

B. acuruana é a única espécie da série Cansenia que apresenta o caráter inflorescências parciais 2-3-floras, associado com folhas inteiras e ovado-oblongas a suborbiculadas, pecíolo sempre com $0,5 \mathrm{~cm}$ comprimento, estípulas lanceoladas e nectários extra-florais rudimentares. Pelo tipo de pétalas mais largas, às vezes com tricomas glandulares na face externa se aproxima do complexo $B$. cheilantha/B. subclavata.

A grafia no protólogo é Bauhinia açuruana e foi mantida por Bentham, na Flora brasiliensis (1870). O Código Internacional de Botânica de Saint Louis (Greuter et al. 2000, artigo 60) é omisso em relação à grafia do "ç" latinizado mas, recentemente, outros autores (por exemplo Lewis, 1987) têm usado a forma adotada neste trabalho.

2. Bauhinia aureopunctata Ducke, Arch. Jard. Bot. Rio de Janeiro 4: 53. 1925. - Tipo. Brasil. Pará, rio Tapajós, Vila Braga, mai 1923 (fl/fr), A. Ducke s/n (lectótipo RB 16959!, aqui designado).

Arvoreta. Entrenó distal do ramo $3 \mathrm{~cm}$ compr. Folhas inteiras, lâmina 18-19(-24) x 5,5$10(13,5) \mathrm{cm}$, tenuemente cartácea, largamente ovado-elítica, base arredondada a atenuada, ápice agudo a acuminado, 7-nérvea, nervura marginal inconspícua, não proeminente, nem infra-nerviforme ou aplanada; face superior glabra inclusive na nervura central impressa, nervuras secundárias impressas, face inferior tomentela, tricomas apressos, curtos, mais ou menos densos, tricomas glandulares presentes, numerosos, nervuras primárias muito proeminentes, secundárias pouco proeminentes e terciárias pouco proeminentes a imersas; pecíolo 2-2,5 cm compr., delgado, tomentelo. Estípulas rudimentares, submilimétricas; nectários extraflorais rudimentares, ca. $1 \mathrm{~mm}$ compr. Inflorescência curto-pedunculada; pedúnculo 1,5 cm compr.; eixo racemiforme, robusto, tomentelo; inflorescências parciais 2floras; folhas alternifloras presentes, semelhantes às folhas normais, porém menores e estreito-lanceoladas, 3-5-nérveas, caducas, em direção ao ápice reduzidas a pares de brácteas foliáceas, submilimétricas rudimentares, nectáriferas. Botões na antese não vistos, até $10 \mathrm{~cm}$ compr. segundo Ducke (1925a), ápice reentrante-obtuso, 5-costados, tomentelos, com tricomas glandulares escassos. Flores com pedicelo ca. $2 \mathrm{~cm}$ compr., bractéolas rudimen-tares; hipanto largamente cilíndrico, 2,5-3,2 x 0,8-1,2 cm, internamente glabro; cálice fendido na antese em 3 lobos reflexos ou eretos, retorcidos ou espiralados, não medidos; pétalas, lineares, ca.4-4,5x0,1 cm, longamente acuminadas, externamente glabras; estaminódios 0 , estames 10 , anteras iguais, lineares, não loceladas, filetes $4 \mathrm{~cm}$ compr. ou maiores, glabros; coluna estaminal rudimentar, submilimétrica, apêndice ligular ausente, interna e externamente glabra; gineceu com estigma claviforme, um dos lados aplanado-escorrente, ovário rufo-tomentelo, estipe $4,5 \mathrm{~cm}$ compr., rufo-tomentelo. Legume deiscente, valvas $21 \times 1,6 \mathrm{~cm}$, tomentelas, estipe $4,5 \mathrm{~cm}$ compr.; lobos funiculares uncinado-lobados. Sementes $11-14 \times 9-11 \mathrm{~mm}$.

Ocorre apenas no Brasil, estado do Pará (Fig. 20), em floresta, nos rios Tapajós e Xingu (Altamira). Folhas IBGE (1960): SA-22 e SB21. Trata-se de uma árvore pequena com o cerne da madeira duro, pardo-avermelhado, (Ducke 1925b).

3. Bauhinia bombaciflora Ducke, Arch. Jard. Bot. Rio de Janeiro 3:104, fig. 5. 1922. - Tipo. 
Brasil. Pará, Itaboca, rio Tocantins, arredores da cachoeira Itaboca, jul 1916 (bt/fl/fr), Ducke s/n (holótipo MG 16236, isótipos R!, RB!).

Figura 4B.

Arvoreta ou arbusto. Entrenó distal do ramo $2-5 \mathrm{~cm}$ comprimento. Folhas bilobadas; lâmina 8,3-12(-32) x 10,1-15 (-32) cm, coriácea, base cordada a subtruncada, 13-15-nérvea, nervura marginal inconspícua, lobos concrescidos em $1 / 3$ a $1 / 2$ do comprimento total, largamente ovados subdivaricados, ápice arredondado a obtuso; face superior glabra, nervuras secundárias não impressas, face inferior vilosa a esparsamente vilosa, inclusive na região das nervuras primárias, tricomas glandulares presentes raros, nervuras primárias, secundárias e terciárias proeminentes; pecíolo 1,5-3,5 cm compr., robusto, viloso-tomentoso. Estípulas assimétrico-subovadas, $5 \times 5 \mathrm{~mm}$; nectários extraflorais cônico-ovóides, 0,5-1 mm compr. Inflorescência até ca. $16 \mathrm{~cm}$ compr., curto-pe-dunculada; pedúnculo 1-1,5 cm compr.; eixos parciais dísticos, dispostos em zigzag, robustos, viloso-tomentosos; inflorescências parciais reduzidas a uma única flor; folhas opositifloras basais presentes, lâmina 3,5-5,5x3$6 \mathrm{~cm}$, progressivamente reduzidas a uma estrutura filiforme e/ou 1 bráctea nectarífera ovada, em direção ao ápice. Botões até 20,5x1$1,4 \mathrm{~cm}$ na antese, subclavados, ápice obtuso e não apendiculado, enérvios, viloso-tomentosos, tricomas glandulares escassos a ausentes. Flores com pedicelo 1-2 cm compr., bractéolas 2 , uma delas ovada e a outra emarginada ou bilobada, às vezes concrescidas, cupuliformes; hipanto cilíndrico, 2,5-6x1-1,5 cm, internamente velutino-tomentoso, cálice fendido na antese em 5 lobos livres, reflexos, espiralados, 10-12 cm compr.; pétalas (segundo Ducke, 1922) lineares, $18 \times 0,1 \mathrm{~cm}$, glabras externamente; estaminódios 0, estames 10, anteras iguais, lineares, não loceladas, filetes $9-20 \mathrm{~cm}$ compr.; coluna estaminal ausente ou rudimentar até 1 $\mathrm{mm}$ altura, apêndice ligular ausente, internamente com tufos de tricomas, externamente rufo-tomentosa; gineceu ex Ducke (1922) até $32 \mathrm{~cm}$ compr., estigma transverso-clavado, ovário rufo-tomentoso, estipe $8 \mathrm{~cm}$ compr., glabro. Legume deiscente, valvas $35-40$ x 2,5-3 cm, tomentosas, estipe 11$12,5 \mathrm{~cm}$ compr.; lobos funiculares filiformes. Sementes $15 \times 10 \mathrm{~mm}$.

Ocorre no Brasil, nos estados de Goiás, Maranhão, Pará e Tocantins (Fig. 21), entre $54^{\circ}-47^{\circ} \mathrm{W} \times 5^{\circ}-14^{\circ} \mathrm{S}$, em cerrado, carrasco, floresta de várzea, floresta decídua e campo. As localidades de ocorrência registradas nas etiquetas dos materiais examinados pertencem às Folhas IBGE (1960): Folhas SB-21, SB-22, SB-23, SC-22, SC-23, SD-22. Endemismo dos médios Araguaia e Tocantins.

Floresce e frutifica de abril a setembro.

As lâminas de folhas estéreis podem alcançar 31x31 cm (col. Mileski 304). Alguns espécimes apresentavam flores com gineceu abortado (col. Mileski 304). Esta é a espécie, com flores de maior tamanho, entre as "bauhinias" brasileiras, daí a denominação dada à especie por Ducke (1922) em uma referência às flores de Pachira aquatica, pertencente à família da Bombacaceae. Ver afinidades taxonômicas sob B. cupulata.

4. Bauhinia brevipes Vogel, Linnaea 13:307. 1839. - Tipo: Brasil. Minas Gerais. Pitangui, 18.dez.1818 (fr), Sellow s.n. (holótipo B, destruído; fotografia RB! ex F negativo 1568).

Pauletia ferruginea Bongard, Mem. Acad. Imp. Sci. St. Petersb., ser. 6, Sci. Math. 4:119. tab 7, fig 1. 1836. - Bauhinia bongardii Steudel, Nom ed. 2:1.191 (err. typ. 291). 1840; Bentham in Martius, Fl. Bras. 15(2):189.1870 Bauhinia ferruginea (Bongard) D. Dietrich, Syn. Pl. 2:1476. dezembro 1840. - Bauhinia ferruginea (Bongard) Walpers, Repert Bot. Syst. 1:848. 1842, non Bauhinia ferruginea Roxburg, Fl. ind., ed Carey 2:331.1832.- Tipo: Brasil. "in sterilibus prope Cuyabá. Flor. februario", sem indicação de coletor e data (LE ?).

Arbusto. Entrenó distal do ramo 1-3,5 cm comprimento. Folhas bilobadas, lâmina 3-5,2 $(-8,5) \times 1,3-3,6(-6,2) \mathrm{cm}$, subcoriácea, base cordada a emarginada ou subtruncada, 7-9-(11-) nérvea, nervura marginal inconspícua, lobos 
concrescidos em $2 / 3$ ou, mais raramente, apenas $1 / 3$ do comprimento total, elíticos a ovadooblongos, paralelos a levemente divergentes, ápice obtuso até agudo; face superior tenuemente pubérula e macia ao toque até glabra, face inferior ferrugíneo-vilosa ou tomentela até hirsútula, especialmente na região das nervuras primárias (não vi fusco-pubérula como descrito para P. bicolor por Bongard (1836), tricomas glandulares presentes abundantes, nervuras primárias e secundárias proeminentes, terciárias pouco ou muito proeminentes; pecíolo $0,5-0,9(-1,5) \mathrm{cm}$ compr., delgado, viloso ou tomentoso. Estípulas lineares, 3-5 mm compr. ou ausentes (caducas ou rudimentares ?); nectários extraflorais lageniformes, ca. $1 \mathrm{~mm}$ compr., a rudimentares, geralmente encobertos pelas estípulas. Inflorescência, geralmente com aspecto paniculóide por brotamento axilar das folhas basais, cada eixo até $27 \mathrm{~cm}$ compr., curtopedunculada; pedúnculo 0,5-2 cm compr., eixo racemiforme, delgado, tomentoso a densamente viloso; inflorescências parciais 2-floras; folhas opositifloras não vistas; brácteas foliáceas lineares, ca.0,3-1 cm compr., nectaríferas. Botões 5x0,5-0,6 cm na antese, subclavados, ápice obtuso a agudo e/ou 5-setáceo, lisos a levemente estriados, densamente ferrugíneotomentosos a fusco-tomentosos, com tricomas glandulares. Flores com pedicelo 0,4-0,5 cm compr.; bractéolas lineares a lanceoladas; hipanto cilíndrico, 0,5-1,3 x0,4-0,5 cm, internamente glabro; cálice fendido na antese em 2-3 lobos reflexos, ondulados a retorcidos e espiralados, 1,5-2,5 cm compr.; pétalas linearlanceoladas, 1,3-2,5x0,1-0,3 cm, externamente com glandulas esparsas e quase imperceptíveis; estaminódios 0 , estames 10, anteras iguais, lineares, não loceladas, filetes $2,2-3 \mathrm{~cm}$ compr., esparsamente pilosos a glabros, coluna estaminal presente, 1-2 mm altura máxima, apêndice ligular ausente, internamente com tufos de tricomas nos bordos fimbriados e externamente glabra; gineceu 2,2 cm compr., estigma crasso claviforme, ovário viloso a tomentoso, com tricomas glandulares, estipe ca.
2,2 cm compr., tomentoso com tricomas glandulares esparsos. Legume deiscente, valvas $8-15,5 \times$ ca. $1,1 \mathrm{~cm}$, tomentoso, estipe 1,5-2,5 $\mathrm{cm}$ compr.; lobos funiculares uncinado-lobados. Sementes 5-7x6-7 mm.

Ocorre na Bolívia e no Brasil, estados de Bahia, Goiás, Minas Gerais, Mato Grosso, Mato Grosso do Sul, Piauí, Rondônia, São Paulo e Tocantins (Fig. 21). Trata-se de uma espécie interiorana coincidindo sua área nuclear com o domínio do cerrado, incluindo formações do tipo cerradão, campo cerrado e margem de floresta de galeria. Também em transição cerradocaatinga (col. Coradin 7597) e caatinga na Bahia, área de montanha (col. Coradin 6351). $\mathrm{Na}$ Bahia, também em campos gerais (col. Harley 21157). Em Rondônia em campo natural (col. Cid 4633). No Brasil os limites são norte/ sul lat $10^{\circ} \mathrm{S}-21^{\circ} \mathrm{S}$, e leste/oeste $42^{\circ} \mathrm{W}-61^{\circ} 62^{\prime} \mathrm{W}$, respectivamente folhas SC-23 (Bahia e Piauí, limite norte $10^{\circ} \mathrm{S}$ ), SD-23 (Bahia e Minas Gerais), SE-23/SF-23 (Minas Gerais e Rio de Janeiro, limite sul $23^{\circ} \mathrm{S}$ ), SD-22, SE-22, SF-22 e SE-21 (Goiás, Minas Gerais, Mato Grosso, Mato Grosso do Sul, São Paulo e Tocantins), folhas SD-20, SC-20 (Rondônia). Talvez esteja extinta no estado do Rio de Janeiro, pois não foi mais coletada desde 1911 (col. A. Lutz 429).

Os espécimes examinados indicam período de floração a partir de abril e plena frutificação (frutos maduros ou passados) em outubro/novembro.

As folhas próximas da inflorescência costumam ser reduzidas, enquanto as folhas basais nos ramos e mais distantes da inflorescência podem ser maiores até 7-8,5 cm de com-primento. Os espécimes Cid 4306 e Cid 4618, procedentes do estado de Rondônia apresentam folhas maiores, sendo que o espécime Cid 4618, coletado em mata de terra firme apresenta folhas $1 / 2$ bilobadas e tem hábito escandente segundo o coletor. Os botões florais com ápice setáceo são freqüentes nas coleções procedentes do Mato Grosso, especialmente as de Cuiabá.

$B$. brevipes compartilha alguns caracteres florais com $B$. ungulata, entre eles, o tipo de 
pétala linear-lanceolada, a coluna estaminal curta e fimbriada em $B$. brevipes e, quase inconspícua, reduzida a apêndices ligulares em B. ungulata, além do tipo de inflorescência multiflora alongada na maturidade e com botões lisos ou levemente estriados.

No protólogo de Bauhinia brevipes, consta como localidade típica "Brasilia pr. Pitargui". Segundo o itinerário de Sellow (cf. Urban, 1906) trata-se de Pitangui. Segundo o índice de topônimos do IBGE (1968) esta localidade fica em Minas Gerais.

5. Bauhinia burchellii Bentham in Martius, Fl. Bras. 15 (2): 186. 1870.-Tipo: Brasil. Goiás: entre Funil e São João, s/data (fr), Burchell 8953 (holótipo K, fotografia do holótipo A!, ex negativo NY 1582).

Subarbusto com xilopódio ou arbusto. Entrenó distal do ramo 2,5-7 cm compr. Folhas inteiras, lâmina 7,5-14 x 7,5-12 cm, coriácea, suborbiculada, base profundamente cordada, ápice arredondado, às vezes curtamente subbilobado, 11-nérvea, nervura marginal inconspícua, face superior glabra, nervuras secundárias impressas, face inferior rufohirsuta principalmente na região das nervuras primárias, tricomas glandulares presentes, nervuras primárias, secundárias e terciárias proeminentes; pecíolo 2-2,5 cm compr., nem delgado, nem robusto, rufo-hirsuto. Estípulas lineares, ca. $6 \mathrm{~mm}$ compr.; nectários extraflorais rudimentares até $1 \mathrm{~mm}$ compr. Inflorescência curto-pedunculada; pedúnculo $2,5 \mathrm{~cm}$ compr., eixo racemiforme, robusto, rufo-hirsuto; inflorescências parciais reduzidas, 2-floras; brácteas foliáceas lineares, nectaríferas. Botões e flores desconhecidos. Hipanto e pedicelos hirsutos nos frutos. Legume deiscente, valvas imaturas 10,5-13,5x1,6-1,8 cm, maciamente rufo-hirsútulas, estipe $2-3 \mathrm{~cm}$ compr.; lobos funiculares uncinado-lobados. Sementes desconhecidas.

Ocorre apenas no Brasil, estados de Goiás e Tocantins (Fig. 20). As localidades de ocorrência registradas nas etiquetas dos materiais examinados pertencem à Folha IBGE
(1960): SC-22, meridianos $48^{\circ}$ e $49^{\circ} \mathrm{W}$ x paralelos $8^{\circ} 9^{\circ}$ e $10^{\circ} \mathrm{S}$. Habita no cerrado em declive, cascalhento com gramíneas e camada de herbáceas dominada por Trachipogon (col. Plowman 8131) e floresta de galeria.

Frutos imaturos em janeiro e março (I.V. Lima 131). Floração desconhecida.

Espécie pouco conhecida. Faltam coleções floríferas e dos frutos maduros. A exsicata examinada (col. I. V. Lima 131) apresenta fruto imaturos, com restos do hipanto, da coluna estaminal e filetes, pseudoracemos terminais, pedicelos $5 \mathrm{~mm}$ compr., bráctea $10 \mathrm{~mm}$ compr. Hipanto (no fruto) 11-12 mm compr., internamente glabro, coluna estaminal externamente glabra e internamente glabra a não ser na porção distal, junto à base dos filetes, barbada.

6. Bauhinia caloneura Malme, Bihang till Kungl. Svenska Vetenskaps -Akad. Handligar 25 (3- n 11): 29. pl.2 fig.4. 1900. - Tipo. Brasil. Mato Grosso, Cuiabá, 22.nov.1893 (bt/fl), Malme I: 1138 (lectótipo S!, designado por Vaz, 1995).

Figura 5a

Arvoreta ou arbusto. Entrenó distal do ramo 1-2 cm compr. Folhas bilobadas, lâmina 5-10,5x $(0,3-2,2) 3,5-8,7 \mathrm{~cm}(0,5-2 \mathrm{~cm}$ compr., na porção proximal do ramo), subcoriácea, base cordada a emarginada, 7-9- nérvea, nervura marginal inconspícua, às vezes subrevoluta, lobos concrescidos em mais do que $2 / 3$ do comprimento total, ovado-oblonos a elíticos, paralelos, ápice obtuso a subagudo; face superior glabra, exceto nas nervuras glabrescentes, face inferior com nervuras ferrugíneo-hirsutas a pilosas, nas demais partes quase glabra, tricomas glandulares ausentes, nervuras primárias e secundárias proeminentes e terciárias pouco proeminentes; pecíolo 0,8-1 cm compr., delgado, ferrugíneo-hirsuto. Estípulas lineares 8-13x0,5-1,5 mm; nectários extraflorais obsoletos, ca. $0,5 \mathrm{~mm}$ compr., geralmente adnados junto à base da estípula no ramo. Inflorescência até $7 \mathrm{~cm}$ compr., pauciflora, até 4-6 flores, curto-pedunculada; 
pedúnculo até $3 \mathrm{~cm}$ compr.; eixo racemiforme, ápice 3-floro, delgado, ferrugíneo-hirsuto; inflorescências parciais 2-3-floras; folhas ausentes, brácteas foliáceas lineares, nectários rudimentares. Botões até $8 \mathrm{~cm}$ na antese, linearprismáticos (segundo Malme, 1900), ápice reeentrante, 5- costados a 5-alados, hirsutos, com tricomas glandulares entre as costas ou alas. Flores com pedicelo $2 \mathrm{~cm}$ compr.; bractéolas lineares; hipanto cilíndrico, 1,2$1,5 \times 0,6 \mathrm{~cm}$, internamente desconhecido, glabro (segundo Malme, 1900); cálice fendido na antese em 3-5 lobos reflexos, ondulados a retorcidos, 4-4,5 cm compr.; pétalas não vistas, segundo Malme (1900) "filiformia v. parte dimidia superiore nonnihil dilatata, vix $1 \mathrm{~mm}$ lata, setaceo-acuminata, glaberrima"; anteras iguais, lineares, não loceladas, filetes $0,8-1,2 \mathrm{~cm}$ compr., glabros; coluna estaminal presente, $4 \mathrm{~mm}$ altura máxima, apêndice ligular não visto, internamente fulvo-hirsuta, externamente glabra; gineceu ca. 7 cm compr., estigma não visto, ovário fulvohirsuto, estipe ca.2,5 cm compr., glabro. Legume deiscente, valvas $10,5-14 \times 1,7-2,1 \mathrm{~cm}$, hirsutas nas suturas a quase glabras, estipe $2,5-4 \mathrm{~cm}$ compr.; lobos funiculares uncinado-lobados. Sementes não vistas.

Ocorre apenas no Brasil, estado de Mato Grosso (Fig. 20). Brasil. As localidades de ocorrência registradas nas etiquetas dos materiais examinados pertencem à Folha IBGE (1960): folha SD-21,56-16a. Cerrado. Arbusto pouco ramoso ou uma árvoreta com $3 \mathrm{~m}$ de altura com casca lisa e macia (col. Malme 1138).

Floresce em novembro e frutifica em junho.

Trata-se de uma espécie endêmica, com área restrita a Cuiabá e Xavantina.

As duas folhas proximais dos ramos laterais são bem menores que as demais (cf. medidas das folhas entre parênteses). Lâmina foliar com a face superior brilhante e a face inferior discolor, apresentando nervuras elevadas e escurecidas no material herborizado.

Espécie pouco conhecida e cujas afinidades não estão ainda definidas.
7. Bauhinia campestris Malme, Arkiv Bot. Stockh. 5(5):10.1905. - Tipo. Brasil. Mato Groso. "Santa Anna da Chapada", 28. jul. 1902 (fl), Malme 2364b (lectótipo S!, designado por Vaz, 1995).

Figura 8

Subarbusto com xilopódio. Entrenó distal do ramo 4,5-5 cm compr.. Folhas bilobadas, lâmina (7,2-)9-13,5x(8,1-)11,5-15 cm, coriácea, base cordada a subtruncada, 7-9-nérvea, nervura marginal inconspícua, lobos concrescidos em 3/4 a 5/6 do comprimento total, quadrado-suborbiculados, divaricados, ápice subagudo a obtuso ou arredondado; face superior glaucescente, glabra ou pilosa só nas nervuras primárias, principalmente na nervura central, nervuras secundárias impressas, face inferior hirsútula, com tricomas curtos e patentes na região das nervuras, canescente ou pálido rufescente tomentosa, ou glabrescente, tricomas glandulares escassos, nervuras primárias, secundárias e terciárias proeminentes; pecíolo 0,4-0,8 cm compr., robusto, tomentoso-hirsútulo, tricomas curtos patentes e densamente agrupados. Estípulas lanceoladas, 4-7x1 mm; nectários extraflorais ovóides, $2 \mathrm{~mm}$ compr., geralmente exsertos. Inflorescência subcorimbiforme até 6-flores e $30 \mathrm{~cm}$ comprimento, longo-pedunculada; pedúnculo 19-24 cm compr.; eixo jovem subcorimbiforme, médio, nem robusto, nem delgado, tomentoso a hirsútulo, glabrescente; inflorescências parciais 2-3-floras; folhas ausentes; brácteas foliáceas rudimentares, nectaríferas. Botões até $8,5 \times 0,6 \mathrm{~cm}$, pentagonais (segundo Malme 1905), ápice 5subcuspidado, 5- estriados, costas não elevadas e cobertas pelo indumento tomentoso no botão jovem até 5-costados, com tricomas glandulares. Flores com pedicelo 0,5-1,5 cm compr., bractéolas rudimentares, hipanto cilíndrico, 0,6-0,9x0,5-0,6 cm, internamente desconhecido; cálice fendido na antese em lobos levemente ondulados a retorcidos, ca. $4 \mathrm{~cm}$ compr.; pétalas, lineares, ca. $3 \times 0,1-0,2 \mathrm{~cm}$, externamente glabras; estaminódios 0 , estames 10 , anteras iguais, lineares, não loceladas, filetes 


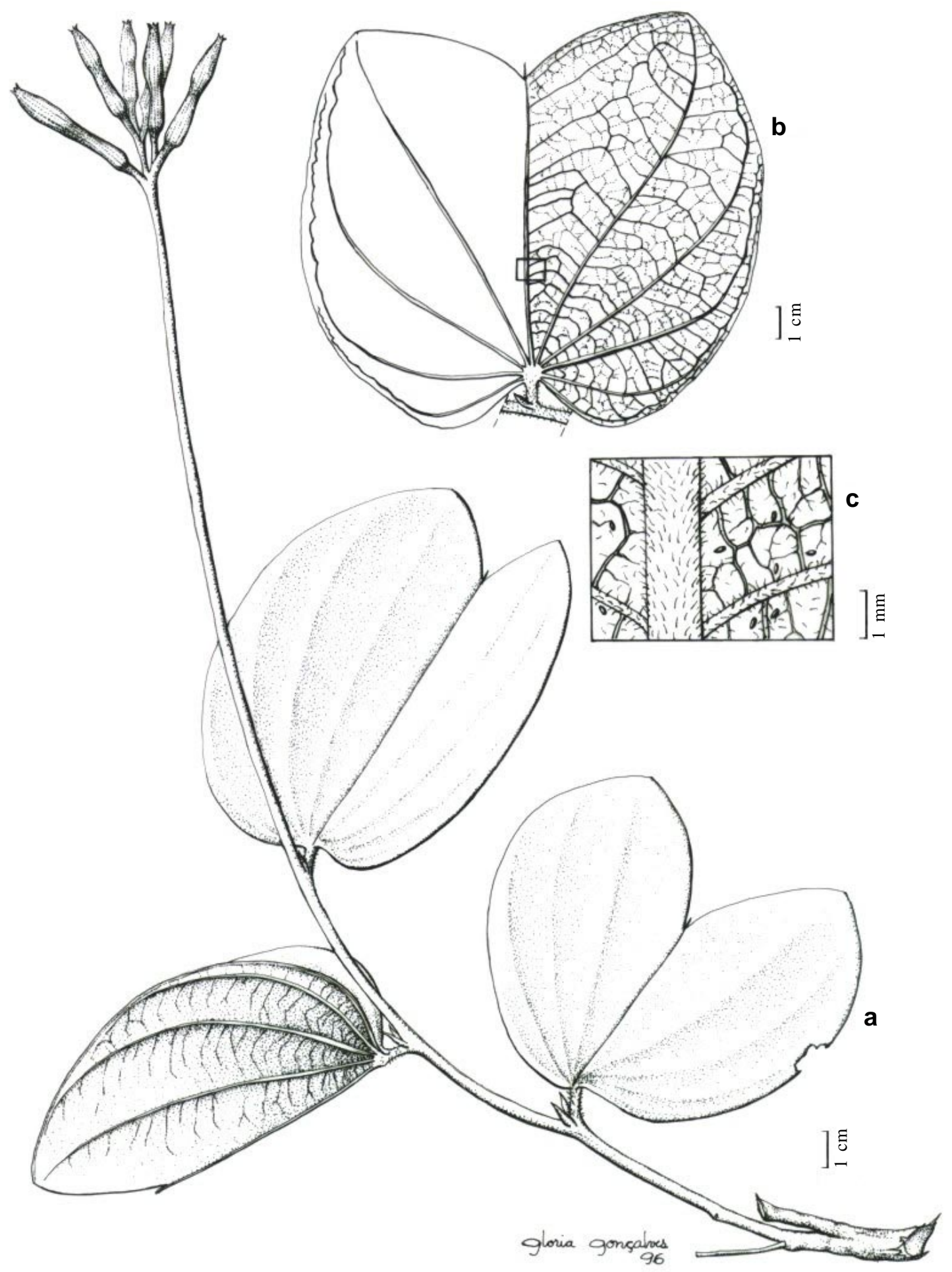

Figura 8 - Bauhinia campestris (col. Malme 2364): a, ramo florífero; b,. contorno foliar; c, detalhe do indumento na face inferior da folha. Desenho G. Gonçalves 1996. 
3,5-4 cm compr., filetes glabros; coluna estaminal $2 \mathrm{~mm}$ altura máxima, apêndice ligular não examinado, internamente hirsuta, externamente glabra; gineceu ca.4,5-5,5 cm compr., estigma claviforme, ovário tomentoso, estipe 1,8-3 cm compr., glabro. Legume desconhecido.

Ocorre apenas no Brasil, estados do Mato Grosso e Mato Grosso do Sul (Fig. 20). As localidades de ocorrência registradas nas etiquetas dos materiais examinados pertencem às Folhas IBGE (1960): SD-21, SF-21 e SE22. Atualmente o nome da localidade tipo é Chapada dos Guimarães, folha SD-21, 56-15d. Habita em campos elevados, principalmente em locais antes de serem submetidos à queimadas (Malme, 1905) e campo cerrado aberto ou campo limpo (col. Hatschbach 25046, 35042). Possui até $70 \mathrm{~cm}$ de altura, com indivíduos crescendo de modo agregado, caule freqüentemente flexuoso, mais ou menos 5angulado (Malme, l.c.)

Floresce de julho a outubro, segundo Malme (1905).

B. campestris é aqui considerada uma espécie distinta de B. malacotricha Harms e, portanto, excluída da sinonimia desta última, tal como proposto pelo próprio Malme (1930). Talvez, B. estrellensis descrita por Hassler (1911), cujo holótipo não foi examinado, procedente do Paraguai, seja sinônimo de $B$. campestris.

B. campestris apresenta como caráter, que a distingue das demais espécies estudadas, o tipo de inflorescência subcorimbiforme longopedunculada.

8. Bauhinia candelabriformis Cowan, Contr. Sci. Los Angeles County Mus. 13:4, Fig.1.1957. - Tipo: Brasil. Goiás, 7 km ao sul de Veadeiros (atual município de Alto Paraíso), Chapada dos Veadeiros, $47^{\circ} 30^{\prime}$ long. W x $14^{\circ} 30^{\prime} \mathrm{S}$, abr. 1956 (bt/fl), leg. Dawson 14581 (holótipo R!, isótipo $\mathrm{RB}$ !, fotografia RB!).

Arvoreta. Entrenó distal do ramo 1-1,5 cm compr. Folhas bilobadas, lâmina 3,5-5x6-7 cm, coriácea, base profundamente cordada, 7-9- nérvea, nervura marginal aplanada, lobos concrescidos em ca 2/3 do comprimento total, elíticos, subparalelos, ápice arredondado a subtruncado; face superior glabra, face inferior pubérula nas nervuras primárias a quase glabra, tricomas glandulares numerosos, nervuras primárias pouco proeminentes e secundárias e terciárias pouco proemimentes a imersas; pecíolo 1-1,4 cm compr., delgado, rufotomentelo. Estípulas rudimentares, submilimétricas, caducas; nectários extraflorais obsoletos, 0,5-1,0 mm compr. Inflorescência até 5-6 cm compr., curto-pedunculada; pedúnculo $0,5 \mathrm{~cm}$; eixo racemiforme duplicado, devido a rebrotamento de gemas reprodutivas no terço inferior do eixo, delgado, rufo-tomentelo; inflorescências parciais 2-floras; folhas reduzidas ao mucro, e então, apenas brácteas foliáceas rudimentares, submilimétricas, nectários extraflorais rudimentares, submilimétricos. Botões até $6,5 \times 0,4 \mathrm{~cm}$ na antese, tubulosos, ápice apiculado, lisos, enérveos, viscídulos, tricomas glandulares numerosos e apressos. Flores com pedicelo 1$1,2 \mathrm{~cm}$ compr., bractéolas escamiformes, submilimétricas; hipanto cilíndrico, $1,5 \times 0,5 \mathrm{~cm}$, internamente irregularmente seríceo-tomentoso na região distal; cálice fendido na antese em 45 , lobos reflexos, ondulados a retorcidos, 3,5 cm compr.; pétalas lineares, ápice agudo,ca.2x0,1 cm, externamente glabras; estaminódios 0 , estames 10, anteras iguais, lineares, não loceladas, filetes $3,5-5,5 \mathrm{~cm}$ compr., filetes alternipétalos, internamente tomentosos; coluna estaminal presente, altura máxima desconhecida, apêndice ligular obsoleto, internamente seríceo-tomentosa, externamente glabra; gineceu $7,5 \mathrm{~cm}$ compr., estigma não visto, ovário com tricomas glandulares, estipe 2,5 cm compr., glabro. Legume desconhecido.

Ocorre apenas no estado de Goiás, na Chapada dos Veadeiros, município de Alto Paraíso (Fig. 22), em cerrado (Felfili 322), afloramentos areníticos (col. Dawson 14581), campo rupestre com solo com cristais de quartzo (observação pessoal). A localidade de ocorrência registrada nas etiquetas dos 
materiais examinados pertence à Folha IBGE (1960): SD-23. É, portanto, um caso de endemismo pontual com uma única população conhecida.

Trata-se de uma arvoreta, $2 \mathrm{~m} \mathrm{x} 10 \mathrm{~cm} \mathrm{e}$ com aparência ornamental (Filgueiras 415), bastante ramificada, ramos curtos e lenhosos. Altitude: 1.500-1.600 m (Filgueiras 415).

Botões e flores em janeiro, abril a junho.

$B$. candelabriformis difere de $B$. goyazensis por apresentar folhas profundamente cordadas e mais altamente concrescidas, inflorescência subcorimbiforme porém, com eixo curto-pedunculado. Também se aproxima de $B$. malacotrichoides que, no entanto, possui folhas bifolioladas.

9. Bauhinia cheilantha (Bongard) Steudel, Nom. Bot., ed. 2, 1:191. agosto 1840. Pauletia cheilantha Bongard, Mem. Acad. Imp. Sci. St. Petersb.,ser. 6, Sci. Math. 4(2):120. 1836. - Tipo. Brasil. Mato Grosso: Cuiabá, jan 1827 (fl), Riedel 773 (holótipo LE, fotografia $\mathrm{BAB}$ !, RB!).

Bauhinia aromatica Ducke, Anais Acad. Bras. Ciênc. 31:295.1959.- Tipo. Brasil, Ceará: Serra de Maranguape, riacho Pirapora, A Ducke 2337 (ectótipo EAC 967!, isolectótipo MG 24481!). Sin nov.

Figuras 2g, 5b, 5c, 9

Arvoreta ou arbusto. Entrenó distal do ramo $2,5-5 \mathrm{~cm}$ compr. Folhas bilobadas, lâmina (4,5-)9,5-15x(5,7)9-12 cm, cartácea a subcoriácea, base profundamente cordada a emarginada ou subtruncada, 9-11(-13-) nérvea, nervura marginal inconspícua, lobos concrescidos em 1/2 - 3/4 do comprimento total, largamente elíticos, paralelos, ápice arredondado a obtusiúsculo; face superior vilosa, glabrescente, nervuras terciárias e quaternárias pouco impressas dando à superfície um aspecto ruguloso, face inferior viloso-hirsútula, especialmente na região das nervuras primárias, tricomas glandulares presentes abundantes, ou tênue pubescentes (serra de Maranguape), nervuras primárias e secundárias mais ou menos proeminentes e terciárias pouco proeminentes; pecíolo 2-3,0 cm compr., delgado, viloso-hirsútulo. Estípulas semilunares, acuminadas, 11-20x1-5 mm ou rudimentares, ovadas ca. 1 mm compr., ou ainda ausentes; nectários extraflorais rudimentares e encobertos pelas estípulas, até $1 \mathrm{~mm}$ comprimento. Inflorescência até $50 \mathrm{~cm}$ compr., curto-pedunculada; pedúnculo 1-5 cm compr.; eixo racemiforme, delgado, viloso-hirsútulo; inflorescências parciais 2-floras; folhas alternifloras presentes, ca. $3,5 \times 1,8 \mathrm{~cm}$ ou reduzidas a brácteas foliáceas estreitolanceoladas, não nectaríferas, 7-15x2 mm. Botões 3,5-6x0,6-1,3 cm na antese, clavados, ápice obtuso, 15-costados, sulcados, costas onduladas em maior ou menor grau, até 15costados ou lisos e 5-sulcado, tomentosos, vilosos ou hirsutos, com tricomas glandulares. Flores com pedicelo $1 \mathrm{~cm}$ compr., bractéolas estreito-lanceoladas, hipanto cilíndrico, 1-2x0,7$0,8 \mathrm{~cm}$, internamente glabro; cálice fendido na antese em 5 lobos eretos a reflexos, retos (= não ondulados, nem retorcidos, nem espiralados), 1,8-3 cm; pétalas obovadooblongas a estreito-obovadas, obtusas, (2,5-)3$4,2 \mathrm{x}(0,3-) 1-2,5 \mathrm{~cm}$, externamente cobertas por tricomas glandulares; estaminódios 0 , estames 10 , anteras iguais, lineares, loceladas (= divididas em pequenos compartimentos) ou não, filetes 1,7-3,5 cm compr., filetes alternipétalos esparsamente pilosos até hirsutos na base ou glabros; coluna estaminal 2-5 $\mathrm{mm}$ altura máxima, internamente com apêndice laciniado hirsuto nos bordos, externamente hirsuta a glabrescente; gineceu ca. $5 \mathrm{~cm}$ compr., estigma subtransverso-capitado, ovário viloso, com tricomas glandulares, estipe $2 \mathrm{~cm}$ compr., glabrescente. Legume deiscente, valvas 8,5$16 x 1,1-1,6 \mathrm{~cm}$, viloso-glandulosas, estipe 2-2,5 cm compr.; lobos funiculares uncinado-lobados. Sementes ca.6x4 mm.

Ocorre no Brasil, Bolívia e Paraguai. Nos estados de Bahia, Ceará, Maranhão, Mato Grosso e Mato Grosso do Sul, Paraíba, Pernambuco, Piauí, Rio Grande do Norte e Sergipe (Fig. 22). São duas áreas de ocorrência disjunta: 1) Do nordeste até Manga, em Minas 

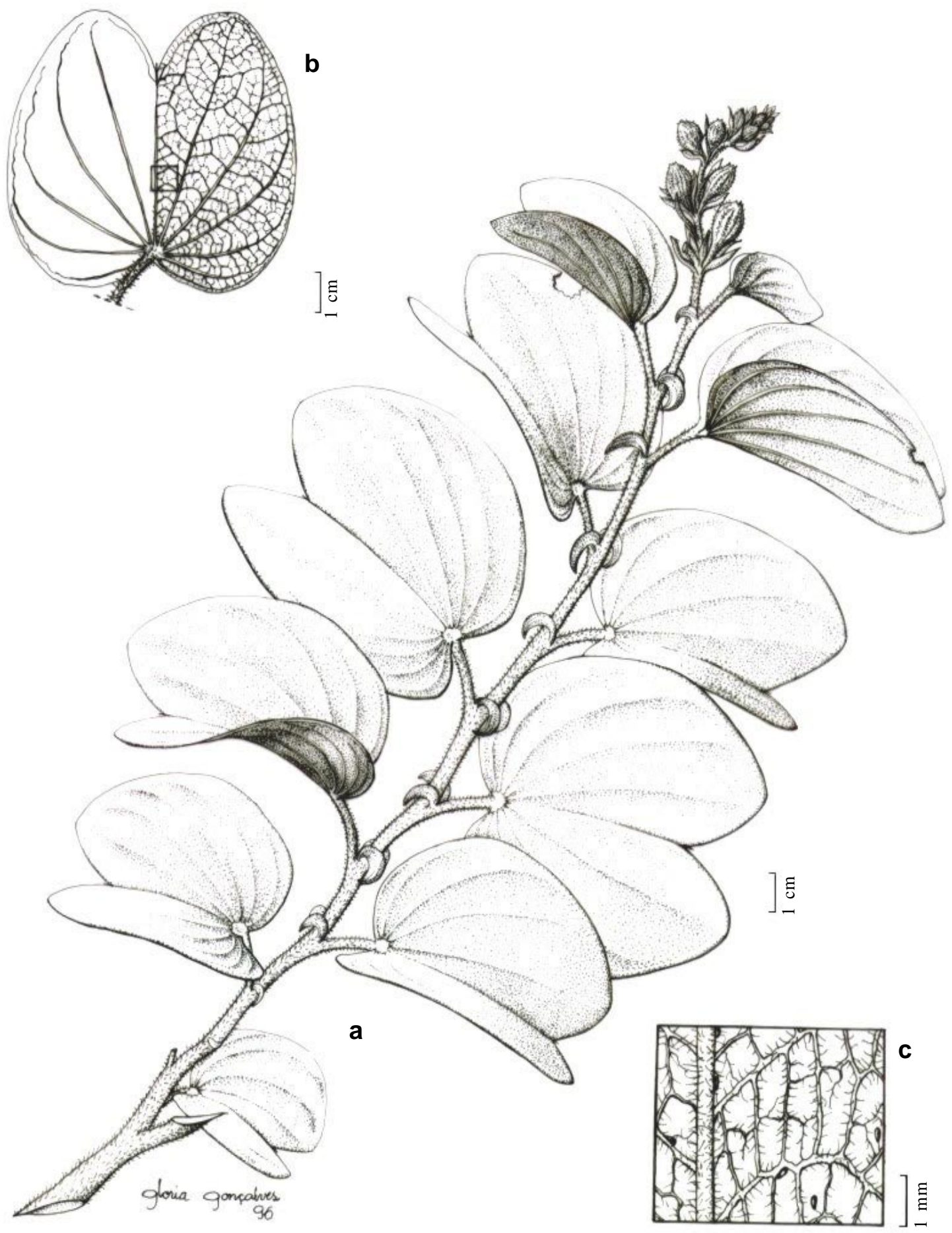

Figura 9 - Bauhinia cheilantha (col. Malme 2627): a, ramo florífero; b, contorno foliar; c, detalhe do indumento na face inferior da folha. Desenho G. Gonçalves 1996. 
Gerais $\left(04^{\circ}-15^{\circ} \mathrm{S}\right.$ lat. $x 36^{\circ}-45^{\circ} \mathrm{W}$ long., respectivamente, em localidades da folhas IBGE (1960): SA-24, SB-23, SB-24, SB-25, SC23, SC-24, SC-25, SD-23 e SD-24). Em caatinga arbórea ou arbustiva, floresta estacional , mata seca, mata de cipó, floresta refúgio e capoeiras. 2) $\mathrm{Na}$ área centro-oeste/Paraguai ocorre nas folhas SD-21, SE-21 e SF-21, $16^{\circ}-20^{\circ} \mathrm{Sx} 56^{\circ} \mathrm{W}$, em área de cerrado mais ou menos seco e de floresta mais ou menos inundável, e também na vegetação arbustiva próximo à Cuiabá (Riedel 773). Na caatinga arbórea tem a forma de uma arvoreta de até $6 \mathrm{~m}$. Na folha SF-23, a ocorrência de B. cheilantha é duvidosa: o único espécime examinado (col. P.Occhioni 7405) representaria uma rara ocorrência de $B$. cheilantha para o estado do Rio de Janeiro, Serra dos Orgãos, "loco Limoeiro". Como não temos conhecimento dessa localidade, não pudemos recoletar a espécie e confirmar a ocorrência. Uma outra coleção de Glaziou 10688 (P), nos campos da Bocaina, sugere a possibilidade de uma área pretérita de distribuição de $B$. cheilantha maior ocorrida nos períodos pretéritos de clima mais seco. $\mathrm{O}$ espécime Glaziou 10688 difere dos demais por ser inteiramente glabro. Nos estados de Mato Grosso/Mato Grosso do Sul foi coletada com botões jovens em novembro, com botões e flores em dezembro até março (últimas flores), e com frutos em fevereiro/março e junho. Não foi possível detectar um padrão determinado de floração/frutificação nos espécimes examinados do nordeste.

Vários coletores citam perfume leve e agradável das flores ou leve odor resinoso das folhas (Queiroz \& Nascimento 3469), a planta exala odor balsâmico forte (Ducke, 1959, como B. aromatica). Esta espécie se caracteriza pelo tipo de indumento macio nas duas faces, pétalas subflabelado-venosas, glandulosas externamente e geralmente anteras loceladas.

Bentham (1870) tratou B. cheilantha no grupo informal das espécies com pétala obtusa e com acúleos, no entanto $B$. cheilantha não apresenta acúleos e sim nectários extraflorais rudimentares e pólen do tipo 3-colpado. Sendo assim verificamos, portanto, que deveria ser incluída em Bauhinia ser. Cansenia, apesar de possuir pétalas mais largas e obtusas. As espécies afins de Bauhinia cheilanta são $B$. subclavata e B. acuruana (tabela 1).

A descrição original Bongard (1836) como Pauletia cheilantha e os 14 espécimes da coleção Malme (S), procedentes de Cuiabá e Corumbá, apresentam em comum botão claviforme, robusto, 15-costado-sulcado, costas onduladas em maior ou menor grau, viloso a hirsuto, com tricomas glandulares; frutos com valvas de $12-16 \mathrm{~cm}$ x 1,1 cm. Nos espécimes coletados na caatinga de Manga, nordeste de Minas em direção do nordeste, até o Piauí, os botões são em geral menos vigorosos, menos hirsutos até tomentosos e 15-costados, as costas bem menos evidentes até obscuras e o botão liso e 5-sulcado, como em Mendes 338. A largura das pétalas, raramente presente nas coleções, parece variável em todas as populações, quer do centro-oeste, quer do nordeste, assim como a presença das estípulas semilunares, entre outros caracteres, é ocasional nos espécimes examinados. Os espécimes examinados de duas áreas disjuntas nordeste e centroeste, apresentam um gradiente no qual não se conseguiu reunir descontinuidades para marcar, sequer uma classificação infraespecífica. Por outro lado, as coleções procedentes dos estados da Bahia, Ceará, Piauí e Pernambuco mostram um gradiente de características de $B$. cheilantha até $B$. subclavata, por exemplo em relação ao botão claviforme, na antese, sendo que nesta última espécie é estreitamente 5-alado nas coleções tipo, e apresenta pétalas linearlanceoladas, agudas, embora um pouco mais largas que as demais espécies da série Cansenia. As folhas do tipo de B. subclavata são ovado-oblongas, mais longas que largas e menos profundamente lobadas, membranáceas e apresso-pubescentes na face inferior, enquanto as dos espécimes de B. cheilantha, procedentes de Mato Grosso (S), tendem a ser largamente elíticas e tão largas quanto longas, mais rígidas e vilosas no dorso. Não existe 
modo infalível de se identificar alguns espécimes de uma ou outra espécie nos estados em que ocorrem juntas, especialmente no material frutífero, de modo que deve haver cautela com a identificação anotada nos espécimes.

Ducke (1959) descreveu B. aromatica, uma nova espécie, com base em um indivíduo arbóreo de cerca de $8 \mathrm{~m}$, encontrado na floresta úmida, que acompanha o riacho Pirapora, na serra de Maranguape, numa altitude de $300 \mathrm{~m}$. O holótipo Ducke 2337 possui folhas ca. 1/2 bilobadas, amplas, tênue-cartáceas, glabras na face ventral, quase glabras na face dorsal, porém com indumento diminuto apressopubescente, discolores, verde cinza na face dorsal. Os botões são menos largos e mais alongados em direção ao ápice que em $B$. cheilantha s. str. Ducke (1959) descreveu $B$. aromatica, como base nas diferenças entre esta e B. subclavata, mas sem levar em consideração as afinidades $\operatorname{com} B$. cheilantha. A espécie de Ducke é sinonimizada aqui, por ser considerada apenas, como uma forma de vida de $B$. cheilantha adaptada à floresta úmida de encosta.

10. Bauhinia cinnamomea A. P. de Candolle, Prodomus 517. 1825 - Tipo: Guiana Francesa. Cayenna: Martin (holótipo não localizado, fotografia RB! ex F negativo 1572).

Arvoreta ou arbusto. Entrenó distal do ramo $2 \mathrm{~cm}$ comprimento. Folhas inteiras, lâmina 7,5-20x4-7 cm, coriácea, elítica, base obtusa, ápice acuminado, 5-7- nérvea, nervura marginal infranerviforme; face superior glabra, nervuras secundárias não impressas, face inferior pubérula, tricomas glandulares esparsos, nervuras primárias pouco proeminentes, secundárias e terciárias imersas; pecíolo 0,8$1,5 \mathrm{~cm}$ compr., delgado, pubescente a quase glabro. Estípulas não vistas; nectários extraflorais cônico-ovóides, 1-2 mm compr., exsertos. Inflorescência até $35 \mathrm{~cm}$ compr., curto-pedunculada; pedúnculo $1,5 \mathrm{~cm}$ compr.; eixo racemiforme, delgado, tenuemente tomentelo; inflorescências parciais 2-floras.
Botões jovens clavado-acuminados, ápice acuminado e não apendiculado, lisos, enérveos, tenuemente tomentelos, sem tricomas glandulares. Flores não vistas. Legume deiscente, valvas $14-25 \times 1,5-2,2 \mathrm{~cm}$, apressopubescentes, estipe 2,5-4 cm cmpr.; lobos funiculares filiformes. Sementes 11-15x8-9 mm.

Ocorre no Suriname, Guiana Francesa, Guiana, Peru e Brasil; nos estados do Amapá (Folhas IBGE: NA-22,53-2d) e Amazonas (Folhas IBGE: SA-19, SA-20, SA-21, SB-19, SB-20: $60^{\circ}-70^{\circ} \mathrm{W}$ x $1-3^{\circ}$ e $7^{\circ} \mathrm{S}$ ). Em floresta de terra firme, de várzea ou ao longo dos rios. $B$. cinnamomea é aqui citada pela primeira vez para o Brasil, na área dos rios Solimões, Purus e Madeira e, também, no Amapá (Fig. 22). Possui ramos descamantes (Huber 4661).

Frutifica de agosto a novembro. Botões em dezembro (col. Vásquez et Jaramillo 8536).

11. Bauhinia conwayi Rusby, Bull. New York Bot. Gard. 8(28): 92. 1912. - Tipo: Bolívia. Tumupasa: jan. 1902 (fl), leg. R.S. Williams 485 (holótipo NY!, isótipo BM!, fotografia RB! ex NY).

Bauhinia tumupasensis Rusby, Bull. New York Bot. Gard. 28(8):93. 1912. - Tipo: Bolívia. Tumupasa: dez 1901, leg. R. S. Willams 495 (holótipo NY!, isótipo BM!). Sin. nov.

Bauhinia straussiana Harms, Notizblatt Bot. Gart. Museuns Berlin-Dahlem 6(59):308. 1915. - Tipo: "Bolivia: Gegiet des Alto Acre, Cobija, im Walde, januar 1912,Ule 9442" (holótipo B, destruído, fotografias RB!, SI! ex F negativo 1617). Sin. nov.

Arvoreta ou arbusto. Entrenó distal do ramo 2-4 cm comprimento. Folhas bilobadas, lâmina 7,5-20x5-13,5 cm, cartáceas a subcoriáceas, base subtruncada a arredondada ou levemente cordada, 7-9-nérvea, nervura marginal inconspícua, lobos concrescidos em ca. de 1/3 do comprimento total ou menos, ovado-lanceolados a oblongo-lanceolados, amplamente divergentes (= divaricados), curtoacuminados, às vezes o ápice se torna obtusiúsculo; face superior glabra ou pilosa na nervura central impressa, nervuras secundárias 
impressas, face inferior viloso-hirsútula; tricomas glandulares não observados, nervuras primárias muito proeminentes, secundárias mais ou menos proeminentes, terciárias pouco proeminentes. Pecíolo 0,4-2 cm compr., delgado ou robusto, viloso-tomentoso. Estípulas assimétrico-subuladas, ca.4-10 mm compr., quebradiças a rudimentares; nectários extraflorais elipsóides a cônico-ovóides, 1-2 mm compr., exsertos. Inflorescência até $32 \mathrm{~cm}$ compr., curto-pedunculada; eixo racemiforme, delgado, tomentoso a velutino; inflorescências parciais 2-floras; folhas alternifloras ausentes, reduzidas a brácteas foliáceas, ca.3-5 $\mathrm{mm}$ compr., subuladas ou rudimentares, nectaríferas. Botões (5-)6-10x0,3-0,4 cm na antese, lineares, ápice subcuspidado a liso, lisos a 5-subcostados, tomentosos, tricomas glandulares não vistos. Flores, pedicelo 0,3-0,7 cm compr., bractéolas ovadas, $2 \mathrm{~mm}$ compr., hipanto cilíndrico a urceolado, 0,7-2x0,3-0,6 cm, internamente glabro; cálice fendido na antese em 2-3 lobos reflexos ou eretos, espiralados ou não, ca.3,5-10 cm compr.; pétalas, lineares, 1,5$3,5 \times 0,1 \mathrm{~cm}$, externamente glabras; estaminódios 0 , estames 10 , anteras iguais, lineares, não loceladas, filetes 5,5-9,5 cm compr., glabros; coluna estaminal presente, $1-4 \mathrm{~mm}$ altura máxima, apêndice ligular ausente, internamente irregularmente velutino-tomentosa na parte superior e glabra na parte inferior, externamente velutino-tomentosa na junção dos filetes; gineceu 6,5-9,5 cm compr., estigma claviforme, um dos lados aplanado-escorrente, ovário hirsútulo-tomentoso, estipe 1,5-4 cm compr., glabro ou quase glabro. Legume maduro não visto, deiscente, valvas $15-16 \times 1,1-1,4$, pubérulas, estipe 3,5-4,5 cm compr.; lobos funiculares curto-triangulares. Sementes maduras não examinadas.

Ocorre na Bolívia e Brasil, nos estados do Acre e Rondônia (Fig. 22). As localidades de ocorrência registradas nas etiquetas dos materiais examinados pertencem às Folhas IBGE (1960): SD-23. Folhas SC.19 e SD.20. Latitude $60^{\circ}$ a $72^{\circ}$ x longitude $8^{\circ}$ a $16^{\circ}$. Em floresta de terra firme ou de várzea, capoeiras.
Ramos às vezes esfoliantes (cf. Williams 485, BM). As folhas com âmbito obovado a rombóide, a distância entre as pontas dos lobos divaricados fica entre 6 e $12 \mathrm{~cm}$, nas folhas maiores.

Floresce de outubro a abril, um exemplar com flores pequenas em julho (col. Prance 5901), frutos imaturos em julho.

Rusby (1912) descreveu na mesma obra B. conwayi e B. tumupasensis com mesma localidade de procedência. Realmente o holótipo de B. tumupasensis tem folhas mais espessas, com pecíolos menores, estípulas mais robustas, com indumento do dorso foliar mais denso do que o holótipo de B. conwayi.

$\mathrm{Na}$ descrição das flores Rusby (1912) afirma que $B$. tumupasensis apresenta filetes glabros e quase livres, enquanto em $B$. conwayi seriam conados e tomentosos na base. $\mathrm{O}$ holótipo de B. tumupasensi, no entanto, apresenta a base dos filetes conada e tomentosa como a descrita para B. conwayi, também as folhas desta última espécie, descritas como glabras face inferior são, na verdade, hirsútulas principalmente ao longo das nervuras principais. Não foram encontrados outros caracteres que justificassem a manutenção de ambos os binômios como espécies distintas. Pode-se aventar a hipótese, a confirmar com novas coleções na localidade tipo, de o tipo de $B$. conwayi corresponder a uma forma de sombra e o tipo de B. tumupasensis ser uma forma de local mais aberto, mais seco e ensolarado.

Anteriormente $B$. conwayi não havia sido assinalada para o Brasil.

12. Bauhinia cupulata Bentham in Martius, Fl. Bras. 15(2):188. 1870. - Sintipos. Brasil. Piauí: Margens do Rio Gurgea, ago 1839 (bt/ fl), Gardner 2529 (BM!, MANCH!, NY!, OXF!, W!, fotografias RB!, negativos IPA 1197 e F 1577); Goiás: "prope Goyaz, Cavalcante, Conceição aliosque locos", Burchell (não localizado); "in eadem provincia ?, Pohl” (não localizado).

Bauhinia cupulata var. longifolia Bentham in Martius, Fl. Bras. 15(2):189. 1870. 
- Tipo. Brasil. Goiás: “in sylvis humidis Sertão d'Amaro-Leite" set/out 1844 (fl), Weddel 2875 (holótipo (?) P!, fotografia RB!). Sin. nov.

Figuras 5d, 10,11

Arbusto ou arvoreta. Entrenó distal do ramo 2,5-4 cm compr. Folhas bilobadas, lâmina 6-15x6-13 cm, coriácea, base cordada a truncada, 9-13 nérvea, nervura marginal inconpícua, lobos concrescidos em 1/2 a 2/3 do comprimento total, largamente ovadooblongos, paralelos a subdivaricados, ápice obtuso; face superior glabra, nervuras secundárias não impressas, face inferior esparsamente vilosa a vilosa na região das nervuras primárias, tricomas glandulares presentes, escassas, nervuras primárias, secundárias e terciárias muito proeminentes; pecíolo 1-1,5 compr., robusto, tenuemente tomentoso. Estípulas ovadas, $2 \times 3 \mathrm{~mm}$, a assimétrico-subovadas; nectários extraflorais cônico-ovóides, 0,5-1 mm compr. Inflorescência geralmente ramificada com aspecto paniculiforme, até $10 \mathrm{~cm}$ compr. ou não ramificada e racemiforme, até $25,5 \mathrm{~cm}$ compr. (Andrade-Lima 76-8261), curto-pedunculada; pedúnculo $1 \mathrm{~cm}$ de compr.; eixo contínuo, robusto, tênue tomentoso; inflorescências parciais 2-floras; folhas opositifloras ausentes e reduzidas a 1-2 brácteas foliáceas, ovadas às vezes com apêndice subuliforme, nectaríferas. Botões 8-10x0,4-0,7 cm na antese, subclavados, ápice obtuso e não apendiculado, lisos, enérveos, tenuemente tomentosos, tricomas glandulares escassas a ausentes. Flores, pedicelo 0,6-1,5 cm compr.; bractéolas 2, uma delas ovada e a outra emarginada ou bilobada, às vezes concrescidas, cupuliformes; hipanto cilíndrico, 1-2x0,7-1 cm compr., internamente velutino-tomentoso, cálice fendido na antese em 5 lobos livres, reflexos, espiralados, $8-8,5 \mathrm{~cm}$ compr.; pétalas lineares, 7-9,5x0,1 cm, glabras externamente; estaminódios 0 , estames 10 , anteras iguais, lineares, não loceladas, filetes 6,5-7,2 cm compr.; coluna estaminal ausente ou rudimentar até $1 \mathrm{~mm}$ altura, apêndice ligular ausente, internamente velutino-tomentosa, externamente pilosa; gineceu 6-12,5 cm compr., estigma transverso-clavado, ovário rufotomentoso, estipe 2,7-5 cm compr., glabro. Legume deiscente, valvas 12-18x1,1-2 cm, glabrescentes, estipe 4-6 cm compr.; lobos funiculares filiformes. Sementes 10-11x6-7 mm.

Ocorre no Brasil, Bolívia, Colombia e Venezuela. No Brasil, estados Goiás, Maranhão, Mato Grosso, Pará, Piauí e Tocantins (Fig. 22). Em cerrado, campo, floresta de galeria, floresta semidecidua, vereda, borda de floresta de galeria/cerrado s.s., floresta ombrófila aberta aluvial na margem direita do Rio Pacuneiro (Ivanauskas 4427). As localidades de ocorrência registradas nas etiquetas dos materiais examinados pertencem às Folhas IBGE (1960):SD-23. Folhas SB-23; SC-23, SC22, SD-21 e SD-22.

Flores quiropterófilas, visitadas por Glossophaga soricina (Silva et al. , 1997). Apresentam dois tipos de flores: hermaforditas e masculinas, devido ao abortamento prematuro do gineceu (Bergallo, 1990; observação pessoal).

Botões de junho a setembro, frutos maduros, setembro a outubro.

Bentham (1870) tinha dúvidas sobre a variedade nova criada por ele com base nos caracteres diferenciais - pecíolo mais longo e tênue, folhas mais profundamente lobadas, ca. $15 \mathrm{~cm}$ comprimento e fruto longamente estipitado. O espécime examinado, foi coletado na época de rebrotação e com frutos passados, demonstra que as diferenças citadas são devidas à fase fenológica do exemplar. As folhas são também menos coriáceas e a nervaçäo menos elevada.

B. cupulata é freqüentemente confundida com $B$. longifolia, principalmente nas áreas em que ocorrem simpatricamente. $B$. longifolia, no entanto, entre outras características possui hipanto e base dos estames interna e externamente glabros, e lobos funiculares curto-emarginados e pólen com processos supratectais gemóides enquanto $B$. cupulata possui hipanto internamente tomentoso e bractéolas cupuliformes, lobos funiculares filiformes. O pólen de B. cupulata, 


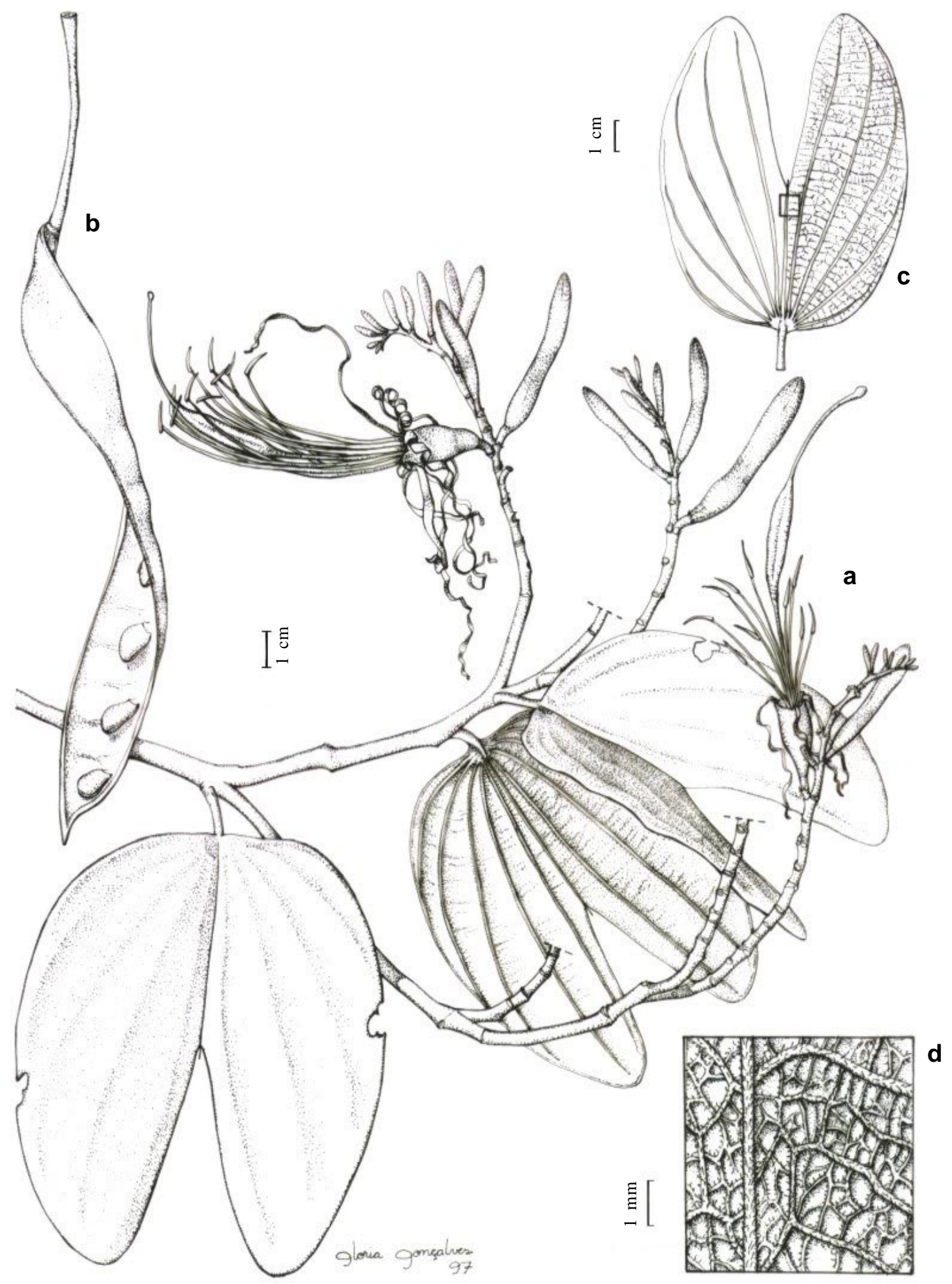

Figura 10 - Bauhinia cupulata (a, c-d, Giordano 1160; b, Vaz 116): a, ramo florífero; b, fruto; c, contorno foliar; d, detalhe do indumento na face inferior da folha. Desenho G. Gonçalves, 1997. 


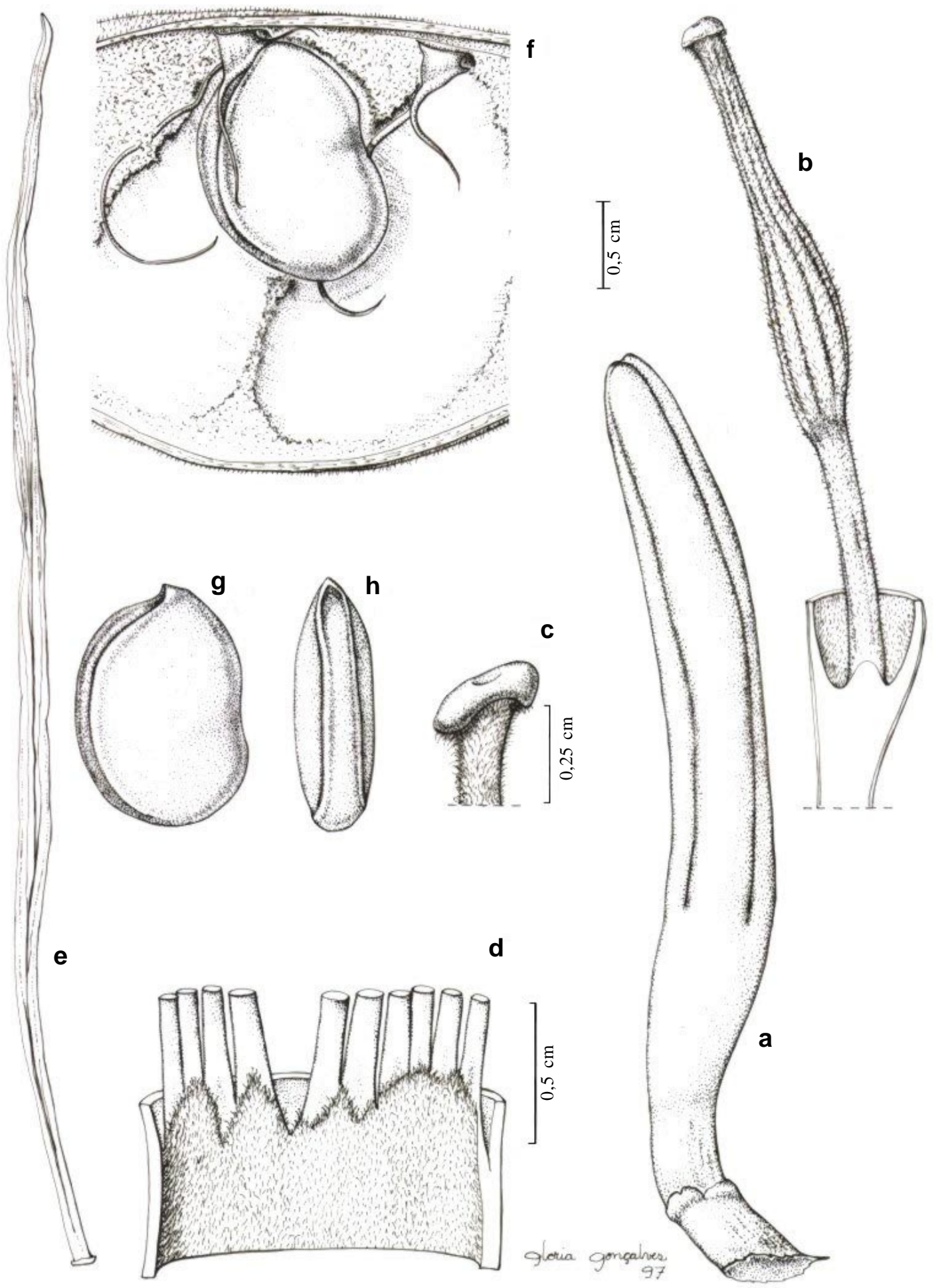

Figura 11 - Bauhinia cupulata (a-e, Vaz 1180; f-h, Vaz 1116): a, botão; b, gineceu, onde se vê inserção do ginóforo no fundo do hipanto; c, detalhe do estigma; d, coluna estaminal em continuidade com a face interna do hipanto; e, pétala na antese; $f$, detalhe da valva com semente; $g$, semente em vista lateral; $h$, semente vista de perfil. Desenho G. Gonçalves, 1997. 
segundo Ferguson \& Pearce (1986, Figs. 15,16 e 17) não apresenta processos supratectais gemóides, e apresenta um estratificação da exina com um teto compactado e columelas curtas. B. cupulata compartilha vários caracteres $B$. bombaciflora, em especial as brácteas subtendentes cupuliformes e o tipo de cobertura na parede interna do hipanto, no entanto $B$. bombaciflora possui botões muito maiores na antese $(20,5 \mathrm{~cm}$ compr.) e inflorescência composta de mônades. O pólen de $B$. bombaciflora é desconhecido, mas deve ser investigado para se verificar as semelhanças com o de B. cupulata, que é muito característico em forma e ortamentação da exina.

13. Bauhinia curvula Bentham in Martius, Fl. Bras. 15(2):194. 1870. - Tipo. Brasil. Goiás: Goiás Velho, "in campis prope Goyaz", 1841 (bt/fr), Weddell 2590 (lectótipo K, aqui designado; fotografia RB! ex NY negativo 1595).

Bauhinia elongipes Cowan, Contr. Sci. Los Angeles County Mus. 13: 6, Fig.2.1957.Tipo. Brasil. Goiás, Formosa, "forest and forest margin along road $22-23 \mathrm{~km}$, east of Formoso, region of southern Serra Dourada, $48^{\circ} 50^{\prime} \mathrm{W} x$ $13^{\circ} 45^{\prime}$ S, mai 1956 (bt/fl), E.Y. Dawson 15051 (holótipo R!, isótipo NY!, fotografia RB!). Sin. nov.

Figs: 12,13

Subarbusto ou arbusto. Entrenó distal do ramo $2-4,5 \mathrm{~cm}$ comprimento. Folhas bifolioladas, cada folíolo (1,5-)2,5-4,2x(0,6-)1$1,8 \mathrm{~cm}$, tênue coriáceo a coriáceo, incurvooblongo, convergente, livre ou concrescido em até $1 / 6$ do comprimento total, ápice obtuso, 34- nérveo, nervura marginal aplanada, não proeminente; face superior glabra, nervuras secundárias não impressas, face inferior tenuemente tomentela a esparsamente apressopubérula, tricomas glandulares abundantes, nervuras primárias, secundárias e terciárias pouco proeminentes a imersas; pecíolo $0,5-1$ cm compr., delgado, tenuemente tomentelo, tricomas glandulares abundantes. Estípulas rudimentares; nectários extraflorais até $2 \mathrm{~mm}$ compr., subuliformes a rudimentares. Inflorescência até $18 \mathrm{~cm}$ compr., curtopedunculada; pedúnculo $0,1-1 \mathrm{~cm}$ de compr.; eixo racemiforme, delgado, tênue tomentoso; inflorescências parciais 2-floras; folhas alternifloras, folíolo 1-2,5x0,3-1,2 cm, progressivamente reduzido em direção ao ápice, brácteas foliáceas escamiformes, às vezes mucroniformes, ou rudimentares a ausentes. Botões $12 \times 0,4 \mathrm{~cm}$ na antese, lineares, ápice apiculado, lisos, enérveos a 5-subcostados, tenuemente tomentelos, com tricomas glandulares. Flores, pedicelo 1-3 cm compr.; bractéolas escamiformes submilimétricas; hipanto cilíndrico, 0,8-1,5x0,6-0,9 cm, internamente irregularmente tomentoso na região distal; cálice fendido na antese em 3-5 lobos, reflexos, levemente ondulados, não retorcidos, cálice 2,7-7 cm compr.; pétalas lineares, ápice acuminado, 1,6-3,7x0,05-0,1 cm, externamente glabras; estaminódios 0 , estames 10 , anteras iguais, lineares, não loceladas, filetes 2,5-5,5 cm compr., glabros; coluna estaminal com 5-8 mm altura máxima, apêndice ligular ausente, internamente tomentosa, externamente glabra; gineceu 4-8,5 cm compr., estigma claviforme, ovário tomentelo- com tricomas glandulares, estipe 1,7-4 cm compr., glabro. Legume deiscente, valvas $8-11,2 \times 0,8-1,0 \mathrm{~cm}$, glabras a esparsamente glandulosas, estipe 2,5$3,5 \mathrm{~cm}$ compr.; lobos funilares curtoemarginados. Sementes 4-5x3-4 mm.

Ocorre no Brasil. Distrito Federal, Goiás, Minas Gerais, Mato Grosso e Pará (Fig. 23). As localidades de ocorrência registradas nas etiquetas dos materiais examinados pertencem às Folhas IBGE (1960): SD-22, SE-22, SD-23 e SE-23, na latitudes $14^{\circ}-19^{\circ} \mathrm{S}$ e longitude $47^{\circ}$ $53^{\circ} \mathrm{W}$; com uma disjunçäo em Mato Grosso, no Juruena, folha SC-21. Habita em campo, campo sujo, campo cerrado, cerrado, cerradão e margem da floresta de galeria em cerrado. Ocorre no Pará, na Serra do Carajás, folhas SA-22 e SB-22, sobre Canga.

Em Goiás, início da floração e flores a partir de janeiro, março/abril até junho (vários 


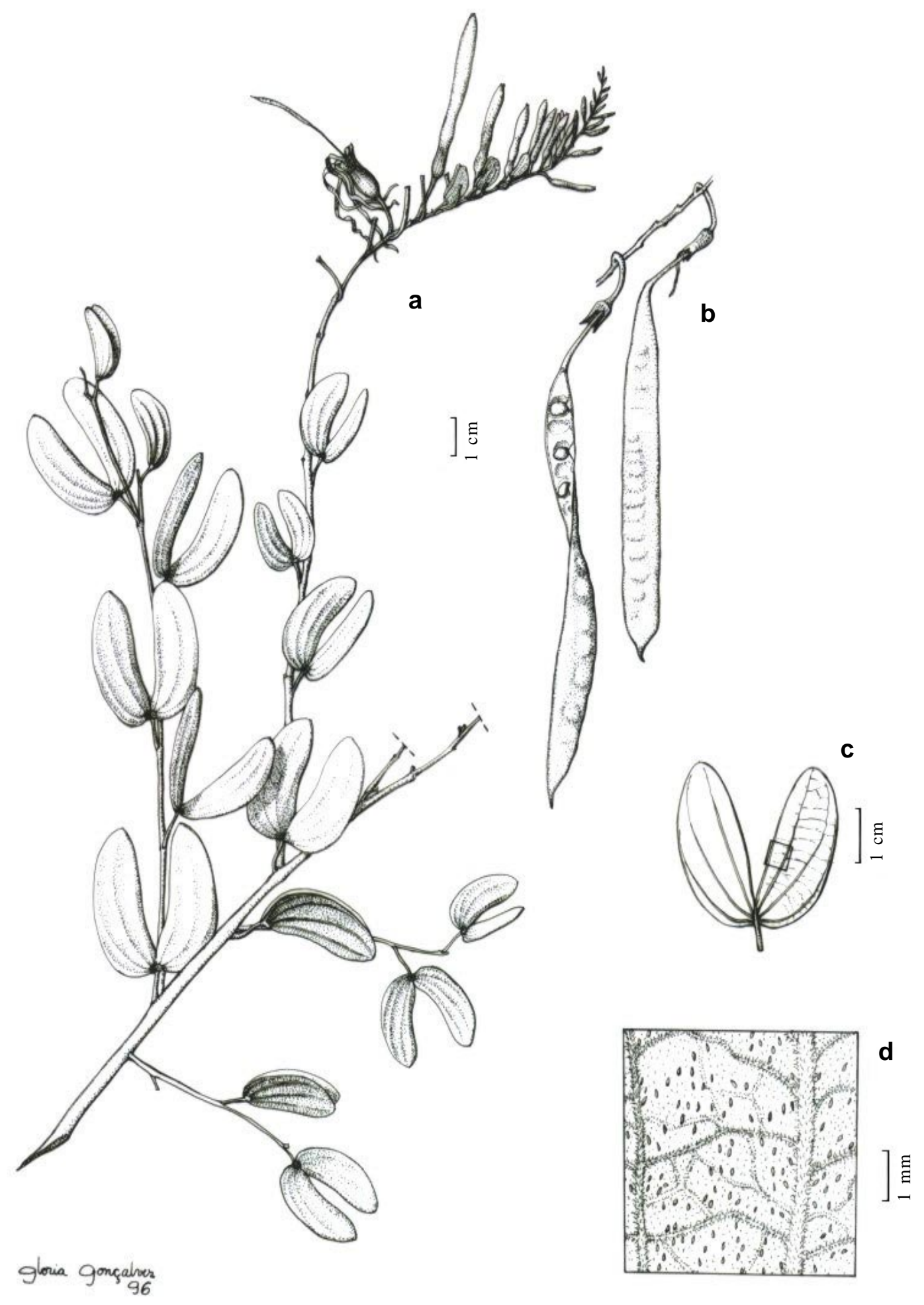

Figura 12 - Bauhinia curvula ( col. Helena 07): a, ramo florífero; b, fruto; c, contorno foliar; d, detalhe do indumento na face inferior da folha. Desenho G. Gonçalves, 1996. 

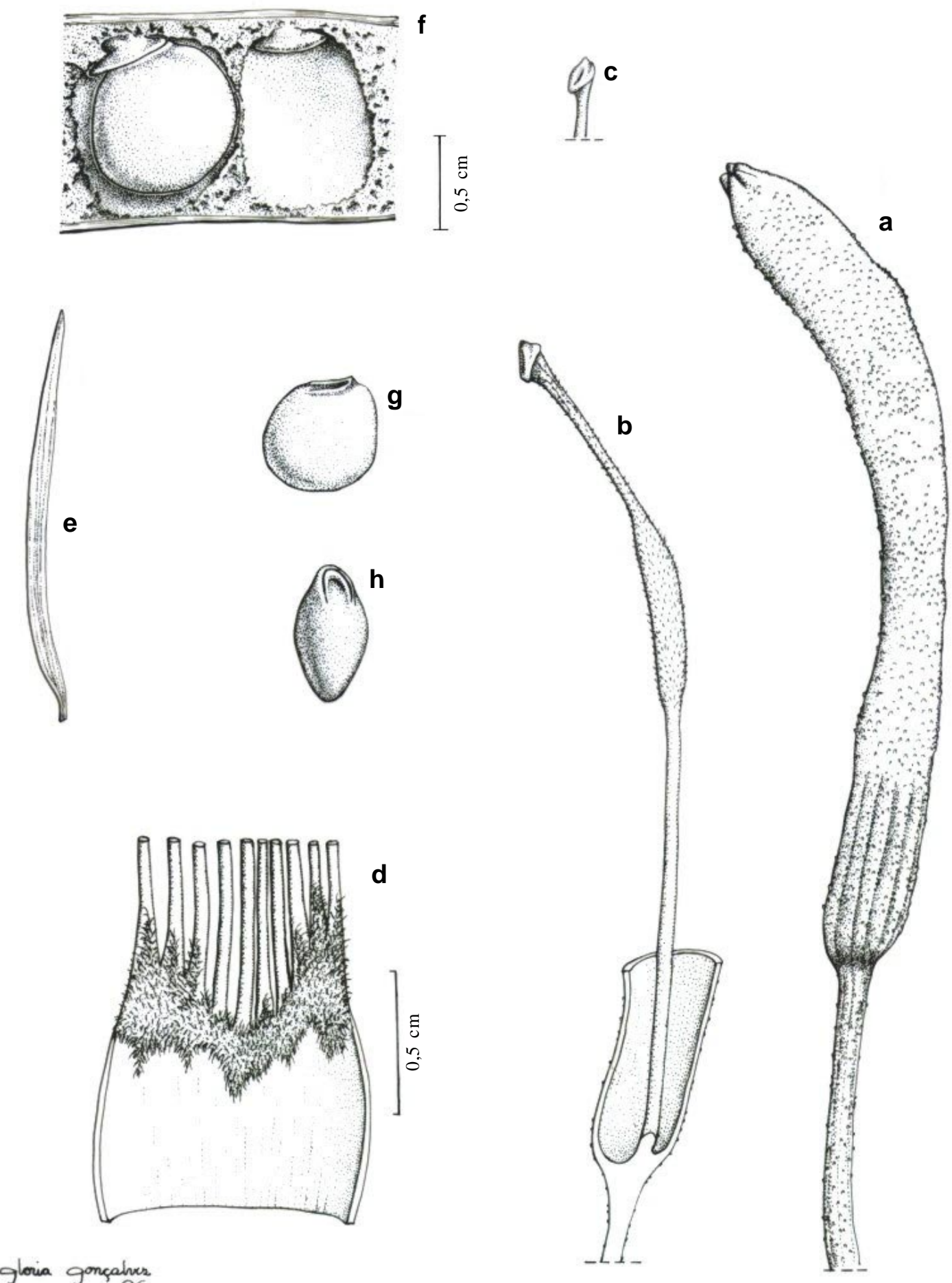

glovia goncahins
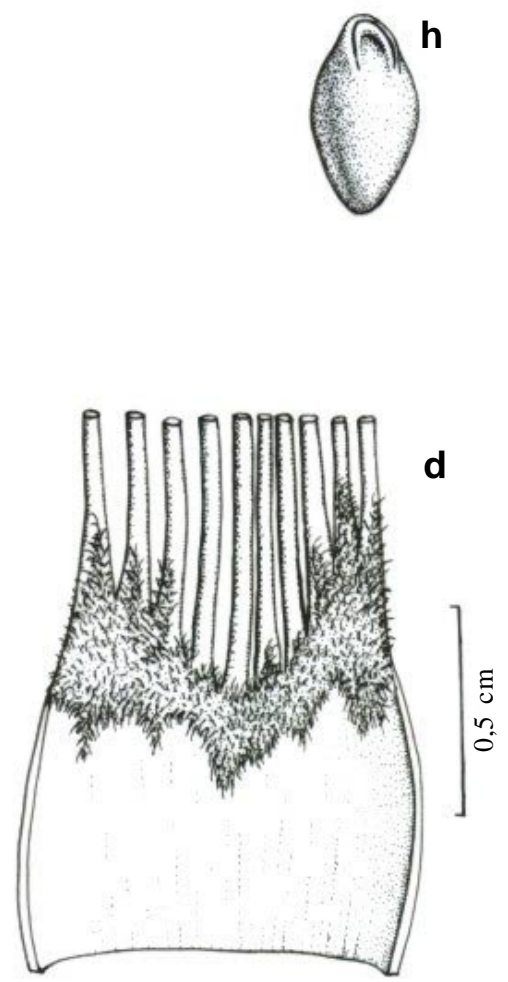

Figura 13 - Bauhinia curvula ( a-d, Rezende 13; e, Heringer 6784; f-h, Marquete 2266): a, botão; b, gineceu, onde se vê inserção do ginóforo no fundo do hipanto; c, detalhe do estigma; d, coluna estaminal em continuidade com a face interna do hipanto; e, pétala na antese; f, detalhe da valva com semente; g, semente em vista lateral; h, semente vista de perfil. Desenho G. Gonçalves, 1996. 
coletores). Exemplares frutíferos em julho a outubro.

Hoehne (1919:34) cita B. pulchella, denominada "cataholo", como planta utilizada pelos índios Nambiquaras, no estado do Mato Grosso, para a aplicação de veneno nas flechas. O espécime citado por Hoehne como $B$. pulchella (col. Hoehne 1990), no entanto, é um exemplar de $B$. curvula.

Cowan (1957) descreveu B. elongipes como muito próxima de Bauhinia pulchella e de Bauhinia curvula mas diferindo, segundo o autor, por apresentar pedicelos longos e finos, com 25-30 mm e, flores grandes. As folhas, segundo o autor, lembram as de Bauhinia curvula. Observação de campo e exame de coleções posteriores confirmam que o espécime tipo de B. elongipes pode ser considerado como uma forma de crescimento da espécie B. curvula, devido à plasticidade, sob o ambiente sombrio de floresta.

Em locais sombrios, em cerradão e floresta de galeria, em Goiás, São João da Aliança e Niquelândia (cf. H. Margon Vaz s/n, RB 325657), apresenta lobos foliares cartáceos, maiores e mais largos até $5,5 \times 3 \mathrm{~cm}$, apenas pubérulos no dorso.

14. Bauhinia dubia G. Don, Gen. Syst. 2:463.1832, non B. dubia Vogel, Linnaea 13: 314. 1839. Tipo: Brasil. Maranhão: jun 1841 (bt/ fl/fr), Gardner 6008 (lectótipo BM!, inédito; isótipo $\mathrm{BM}$, fotografias RB!).

Bauhinia nitida Bentham, in Martius, Fl. Bras. 15 (2):184. 1870.- Tipo. Brasil. Tocantins: "campis siccis sylvaticis prope Natividade", s/ data (bt/fr), Gardner 3122 (lectótipo K, designado por Wunderlin in sched., ined.; fotografia RB! ex F negativo 1598; isótipos $\mathrm{BM}$ !, OXF!, fotografia RB ex $\mathrm{K}$ negative 16416). Sin. nov.

Bauhinia viridiflorens Ducke, Arch. Jard. Bot. Rio de Janeiro 5:129.1930. Bauhinia viridiflora Ducke Arch. Jard. Bot. Rio de Janeiro 3: 105.1922, non Bauhinia viridiflora Backer (1920). - Tipo. Brasil. Pará: Estrada de ferro Alcobaça, rio Tocantins jan.
1915 (bt/fl/fr), Ducke s/n(RB!, lectótipo aqui designado; isólectótipos MG 15597!, R!).

Figs: 14,15

Subarbusto ou arbusto. Entrenó distal do ramo 3-4 cm comprimento. Folhas inteiras, lâmina $(3,5) 6-14,5 \times(2) 3,2-8,5 \mathrm{~cm}$, tenuemente cartácea a coriácea, ovado-oblonga a largamente ovada, base cordada ou subtruncada até obtusa, ápice longamente acuminado a obtuso, 5-7- nérvea, nervura marginal inconspoícua, face superior glabra ou pilosa na nervura principal impressa, nervuras secundárias não impressas, face inferior pubérula a glabra, tricomas glandulares ausentes ou presentes, nervuras primárias proeminentes, secundárias pouco proeminentes, e terciárias e seguintes pouco proe-minentes, densamente reticuladas; pecíolo 0,5-1,5 cm compr., delgado, pubérulo. Estípulas rudimentares, submilimétricas; nectários extraflorais oblongoovóides, 1-3 mm compr., exsertos. Inflorescência até $20 \mathrm{~cm}$ compr., curtopedunculada; pedúnculo 1-1,5 cm compr.; eixo racemiforme, delgado, pubérulo; inflorescências parciais 2-floras; folhas alternifloras ausentes ou presentes, lâmina $5 \times 3,8$ $\mathrm{cm}$, progressivamente reduzidas, em direção ao ápice a forma de brácteas foliáceas duplamente lanceoladas, nectaríferas. Botões 7 x 0,2 - 0,3 $\mathrm{cm}$ na antese, lineares, ápice 5-subcuspidado, setas caducas, lisos, enérveos a levemente 15costados, pubérulos, com tricomas glandulares. Flores, pedicelo 0,5-1,5 cm compr., bractéolas escamiformes, submilimétricas; hipanto cilíndrico a urceolado, 1-1,5x0,5 cm compr., internamente glabro; cálice fendido na antese em 2-3 lobos, eretos, re-torcidos ou não, 3,54,5 cm compr.; pétalas lineares, $1,3-2 \times 0,1 \mathrm{~cm}$, externamente glabras; estaminódios 0 , estames 10 , anteras iguais, lineares, não loceladas, filetes ca.5,5-6,5 cm compr.; coluna estaminal presente, 7-8 mm altura máxima, apêndice ligular ausente, internamente rufo-vilosa, externamente glabra a vilosa na junção dos filetes; gineceu ca. $8 \mathrm{~cm}$ compr., estigma claviforme, um dos lados aplanado-escorrente, ovário glabro, com tricomas glandulares, estipe ca.3,5 cm compr., 


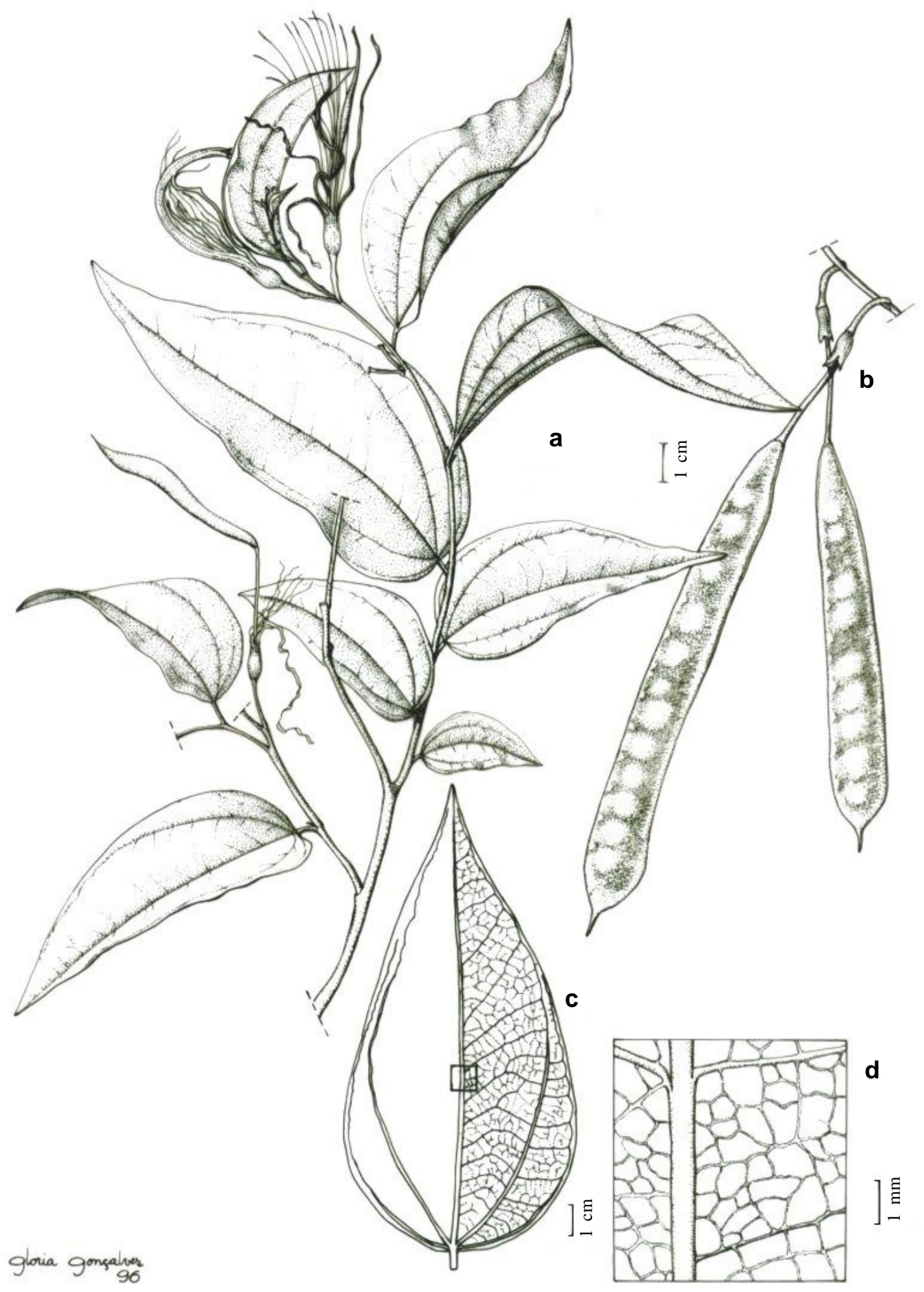

Figura 14 - Bauhinia dubia ( a-c, d, Vaz 706; b, Lima 1560): a, ramo florífero; b, fruto; c, contorno foliar; d, detalhe da face inferior da folha glabra. Desenho G. Gonçalves, 1996. 

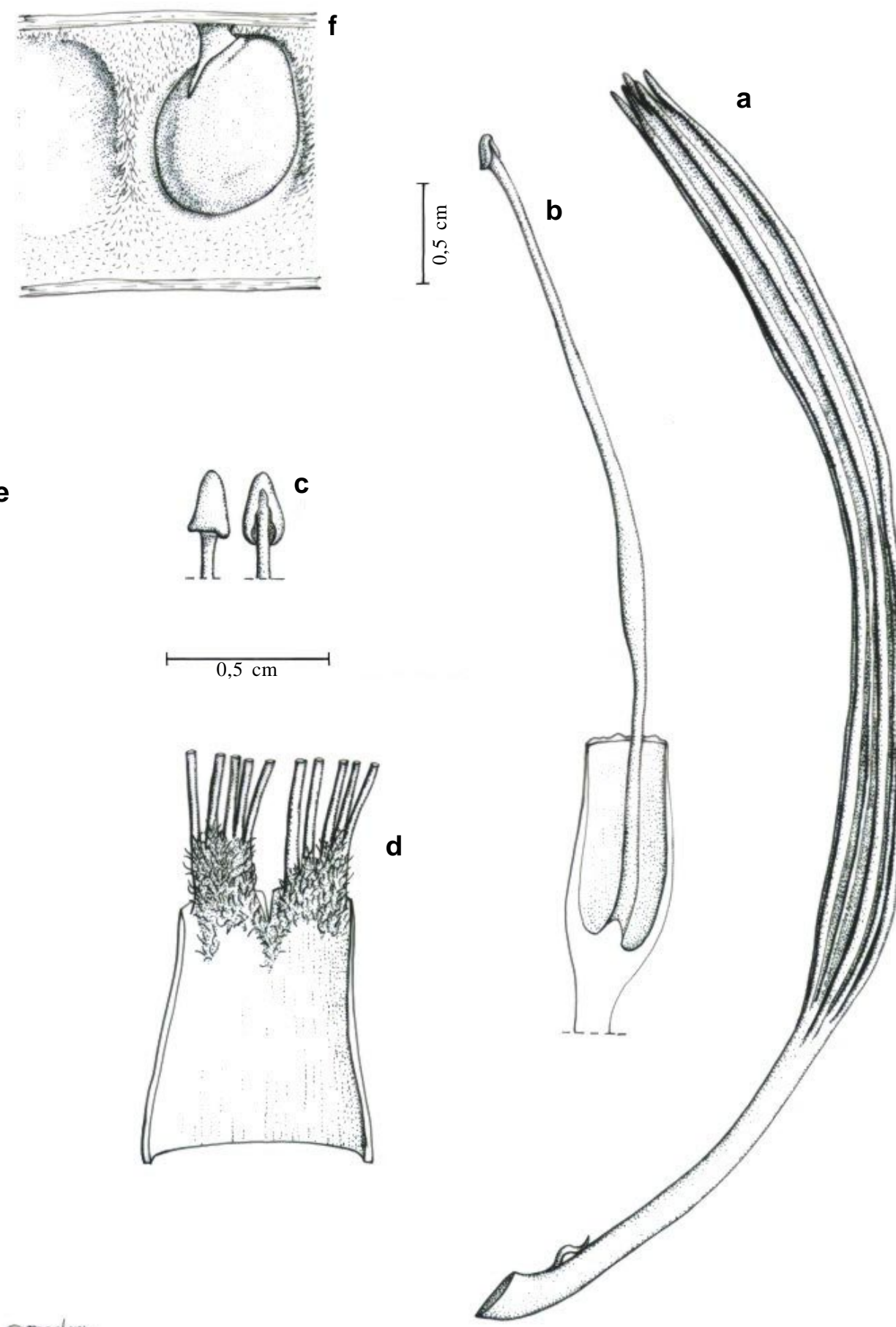

gloia gongahner
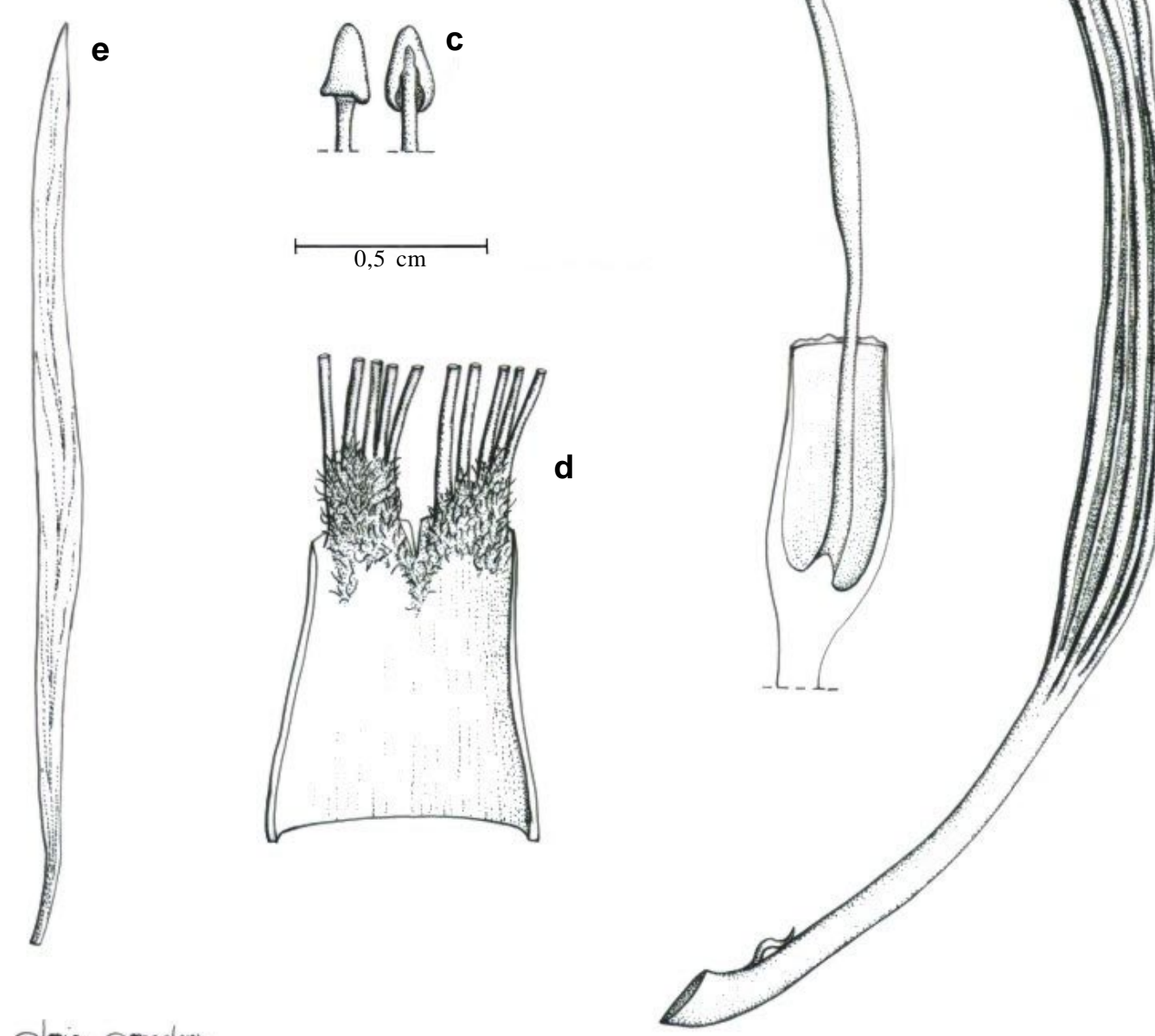

Figura 15 - Bauhinia dubia (a-d, Vaz 708; e, Vaz 706): a, botão; b, gineceu, onde se vê inserção do ginóforo no fundo do hipanto; c, detalhe do estigma; d, coluna estaminal em continuidade com a face interna do hipanto; e, pétala na antese; f, detalhe da valva com semente. Desenho G. Gonçalves, 1996. 
glabro. Legume deiscente, valvas 14-15x1,3$1,7 \mathrm{~cm}$, glabras, estipe 3,5-4 cm compr.; lobos funiculares curto-triangulares. Sementes $7 \times 5$ $\mathrm{mm}$.

Ocorre apenas no Brasil, nos estados do Ceará, Goiás, Maranhão, Pará, Piauí e Tocantins (Fig. 23). As localidades de ocorrência registradas nas etiquetas dos materiais examinados pertencem às Folhas IBGE (1960): Folhas SA-22, SA-23, SA-24, SB22, SB-23, SB-24, SC-22, SC-23, SD-23. Em "carrasco", cerrado (inclusive, campo cerrado e cerradão), além de transição caatinga/ cerrado, caatinga (Russas, no Ceará e Jaicós no Piauí), floresta (Cocal no Piauí), margem de floresta de areia branca (Tucuruí, Pará). Arbusto pequeno das capoeiras secas e da mata perto dos campos no estado do Pará (= B. nitida, Ducke, 1925a, b).

As pétalas são involutas. Pode ser um arbusto apoiante (Salino 3905).

Floresce de novembro a janeiro, frutifica de janeiro a julho.

Bentham (1870) descreveu B. nitida com base em material de Goiás/Tocantins. De fato, os espécimes procedentes de tal região, assim como os do Maranhão adjacente apresentam folhas amplamente cordadas e curtamente acuminadas, coriáceas e glabras na face inferior; brilhantes, muito reticuladas e nigrescentes na face superior. Mas este conjunto de caracteres não se mostra forte $o$ suficiente para a manutenção de $B$. dubia e $B$. nitida como espécies distintas como foi aceito por Bentham (1870). Então, após o exame das coleções procedentes de Palmas, no estado do Tocantins (HEPH), considera-se os dois binômios como sinônimos.

Ver também comentários sob $B$. longicuspis.

15. Bauhinia dumosa Bentham in Martius, Fl. Bras. 15(2):194. 1870. - Tipo. Brasil. Goiás: entre Goiás e Cavalcante, mai 1865 (bt/fr), Burchell 7790 (K, lectótipo aqui designado, fotografia NY negativo 1594, fotografia RB!).

Subarbusto com xilopódio ou arbusto.
Entrenó distal do ramo 2-2,5 cm compr. Folhas bifolioladas a bilobadas, se bilobadas, os lobos concrescidos em ca. de 1/3 do comp. total, base emarginada (subcordada) até profundamente cordada, cada lobo ou folíolo 1,1-5-(7)x0,5-2,7$(4,5) \mathrm{cm}$, cartáceo a sub-coriáceo, 3-5-nérveo, nervura marginal aplanada, largamente elítico a ovado-elítico a subreniforme, paralelo a divergente, ápice arredondado a obtuso; face superior glabra, às vezes esparsamente pilosa, face inferior tomentoso-hirsútula a viscídula, especialmente na região das nervuras primárias a glabrescentes (folhas maiores, na parte inferior do ramo), tricomas glandulares presentes abundantes, nervuras primárias pouco proeminentes, secundárias e terciárias pouco proeminentes a imersas; pecíolo $0,3-1 \mathrm{~cm}$ compr., delgado, rufo-tomentoso. Estípulas lineares, 2-4 $\mathrm{mm}$ a rudimentares; nectários extraflorais subuliformes a rudimentares, 0,5-2 $\mathrm{mm}$ compr. Inflorescência até $27 \mathrm{~cm}$ compr., curto-pedunculada; pedúnculo $0,5-1 \mathrm{~cm}$; eixo racemiforme, delgado, sordido-tomentosohirsuta; inflorescências parciais 2-floras; folhas subopositifolias, lobos/folíolos 0,5-2x0,4-1,2 cm, nectários extraflorais subuliformes a rudimentares. Botões 7-10x0,4 cm na antese, lineares, ápice 5-reentrante-agudo, lisos, enérveos a 5-subcostados, tomentoso-hirsútulos, com tricomas glandulares numerosos e apressos. Flores com pedicelo 1,5-2,2 cm compr., bractéolas escamiformes, submilimétricas, hipanto cilíndrico, 0,7-2x0,5-0,8 cm, internamente irregularmente seríceo-tomentoso na região distal; cálice fendido na antese em 45 lobos reflexos, ondulados a retorcidos, 3,5-6 cm compr.; pétalas lineares, ápice agudo, ca.2,2$3,3 \times 0,1 \mathrm{~cm}$, externamente glabras; estaminódios 0 , estames 10 , anteras iguais, lineares, não loceladas, filetes $3-5,5 \mathrm{~cm}$ compr., filetes alternipétalos, internamente tomentosos, coluna estaminal presente, $7 \mathrm{~mm}$ altura máxima, apêndice ligular obsoleto, internamente tomentosa, externamente glabra; gineceu 5-8 cm compr., estigma claviforme, ovário tomentoso-hirsútulo, com tricomas glandulares, estipe 2-2,8 cm compr., glabro. Legume 
deiscente, valvas $8,5-15 \times 0,9-1,3 \mathrm{~cm}$, pubérulo a glabro, estipe 3-3,8 cm compr.; lobos funiculares curto-emarginados. Sementes 5$6 \times 5-4 \mathrm{~mm}$.

15a. B. dumosa var. dumosa Bentham. Tipo: Ver sob B. dumosa.

Arbusto, esgalhado desde a base (Vaz 817) ou Subarbusto com xilopódio 0,7 a 1,5 m de altura.

Ocorre apenas no Brasil, estados da Bahia, Goiás e Distrito Federal (Fig. 23). As localidades de ocorrência registradas nas etiquetas dos materiais examinados pertencem às Folhas IBGE (1960): folhas SD-22, SD-23. Em cerrado, cerrado transição para campo, campo sujo e campo limpo (vários coletores). Ocorre em altitudes, entre 630 até $1120 \mathrm{~m}$ (vários coletores).

Segundo a diagnose (Bentham, 1870) $B$. dumosa se distingue por apresentar folhas bilobadas, com 1,2 - 1,8 cm compr., lobos um pouco mais largos que longos obtusíssimos e concrescidos em menos da metade do comprimento total, face inferior tomentosahirsuta e com nervuras secundárias e terciárias mais ou menos proeminentes, botão floral obscuramente estriado, pétalas lineares e ovário híspido. Com o aumento das coleções e a partir de observações de campo, em Goiás, observouse que as folhas descritas na diagnose correspondem aos ramos floríferos curtos, distais, e que o ramo principal apresenta folhas maiores e glabrescentes, à medida que se distanciam da região distal em direção à base.

Exemplares com botões e flores de novembro a setembro, e com exemplares em plena frutificação em setembro e outubro.
Os espécimes Gates et Estabrook 105 (CEN, RB, SP); P.I. Oliveira 488 (MBM, RB) e Irwin et al. 12658 (US, foto RB) todos procedentes de Alto Paraíso, diferem da variedade típica por apresentar folhas mais altamente conadas, lobos mais largos, e com ápice quase truncado, além de estípulas lineares maiores. Os exemplares Vaz et Alvarenga 893, 894, 905, 908, 914, 916 (RB), todos coletados na Reserva Biológica do IBGE em Brasília, e identificados como B. dumosa var. viscidula, se apresen-tam na verdade como intermediários entre as duas variedades, com ramos e indumento de $B$. dumosa var. viscidula, mas com folhas bilobadas.

15b. Bauhinia dumosa var. viscidula (Harms) Vaz \& Marquete, Revta. brasil. Bot. 16(1):97. 1993. - Bauhinia viscidula Harms, Bot. Jahrb. 33(72):22. 1903. - Tipo. Brasil. Goiás: entre "Ciganos e As Brancas", dez 1894, leg. Glaziou n. 21010 (lectótipo RB!, designado por Vaz et Marquete, 1993; isolectótipo K!).

Arbusto delgado, com xilopódio, 0,5 a 1,5 m.

Ocorre apenas no Brasil, Distrito Federal e Goiás. As localidades de ocorrência registradas nas etiquetas dos materiais examinados pertencem à Folha IBGE (1960): SD-23. Em cerrado e campo rupestre de Alto Paraíso. Foram assinaladas as altitudes $750 \mathrm{~m}$ (Irwin et al. 11132) e, entre 1.000 e $1.200 \mathrm{~m}$ (vários coletores).

Trata-se de um registro de endemismo às áreas do Distrito Federal e do município de Alto Paraíso de Goiás.

Espécimes floríferos a partir de outubro a fevereiro, com frutos imaturos a partir de janeiro, fevereiro a setembro.

\section{CHAVE PARA AS VARIEDADES DE B. DUMOSA}

1. Folhas bilobadas, lobos elíticos, face inferior e ramos tomentoso-hirsútulos, caule ramificado no ápice Bauhinia dumosa var. dumosa

2. Folhas bifolioladas, folíolos subreniformes, face inferior e ramos viscídulos, caule não ramificado, ou com ramos apenas duplicados Bauhinia dumosa var. viscidul 
16. Bauhinia fusconervis (Bongard) Steudel, Nom. Bot. ed. 2, 191. agosto 1840. - Pauletia fusco-nervis Bongard, Mem. Acad. Imp. Sci. St. Petersb., ser. 6, Sci. Math. 4:116. 1836. Tipo. Brasil. "in sylvis Morro Grande, inter Parahyba et Parahybuna", mai 1824 (fl), Langsdorff (holótipo LE, fotografia BAB!, $\mathrm{RB}$ !).

Bauhinia sellowiana Vogel, Linnaea 13:306.1839. - Tipo: Brasil. Minas Gerais: "prov. Marianna", sem data (fr), Sellow s/n, (holótipo $\mathrm{B}$, destruído; fotografia RB! ex F negativo 1575). Sin. nov.

Arbusto. Entrenó distal $2 \mathrm{~cm}$ comprimento. Folhas bilobadas, lâmina 4,0-6,5(8,0)x2,2$5,0(7,0) \mathrm{cm}$, cartácea, base subtruncada, emarginada a cuneada, 5-7- nérvea, nervura marginal aplanada, lobos concrescidos em 1/3 a 2/3 do comprimento total, elíticos, subparalelos a divergentes, ápice obtuso; face superior glabra, nervuras secundárias não impressas, face inferior pubescente e/ou rufo-tomentela, especialmente nas nervuras primárias, tricomas glandulares presentes, nervuras primárias pouco proeminentes, secundárias e terciárias pouco proeminentes a imersas; pecíolo $8-10 \mathrm{~mm}$ compr., delgado, tomentelo. Estípulas rudimentares, submilimétricas; nectários extraflorais subuliformes, incurvos, ca. de $1 \mathrm{~mm}$ compr. Inflorescência até $8 \mathrm{~cm}$ compr., curtopedunculada; pedúnculo $1,5 \mathrm{~cm}$; eixo racemiforme, delgado, tomentelo; inflorescências parciais 2-floras; folhas opositifloras, lâmina 2,1-3x1,3-2,2 cm, progressivamente reduzidas a 1-2-brácteas foliáceas, nectaríferas. Botões $6,5 \times 0,3 \mathrm{~cm}$ na antese, pentagonais, ápice reentrante-obtuso, 5-costados, tomentelos, viscídulos, com tricomas glandulares. Flores pedicelo 1-1,5 cm compr.; bractéolas escamiformes submilimétricas; hipanto cilíndrico, 1,5-2,2x0,6cm, internamente irregularmente seríceo-tomentoso na região distal; cálice fendido na antese em 3-5 lobos, reflexos, ondulados a retorcidos, ca. $4-5 \mathrm{~cm}$ compr.; pétalas lineares, ápice acuminado, 2,52,8x0,1 cm, externamente glabras; estaminódios 0 , estames 10 , anteras iguais, lineares, não loceladas, filetes 3,4-4,5 cm compr., glabros, exceto os dois laterais alternipétalos; coluna estaminal com $7 \mathrm{~mm}$ altura máxima, apêndice ligular obsoleto, internamente seríceotomentosa, externamente glabra; gineceu compr. desconhecido, estigma claviforme, ovário tomentelo, estipe glabro. Legume deiscente, valvas 11,5-12,5x1-1,4 cm, pubescente, estipe $3,0 \mathrm{~cm}$ compr.; lobos funiculares curto-emarginados. Sementes não vistas.

Ocorre apenas no Brasil, Minas Gerais (Fig. 23). As localidades de ocorrência registradas nas etiquetas dos materiais examinados pertencem às Folhas IBGE (1960): SE-23, 42/44 long. x 19/20 ${ }^{\circ}$ lat.; SF-23, 40/43 long. $\mathrm{x} 21^{\circ}$ lat. Em domínio de floresta Atlântica. Planta da encosta de mata secundária (Kuhlman 81); capoeira de alto de morro (Lopes 262). Arbusto bastante ramificado, ramos flexíveis (Leoni GFJP 1503). Cálice verde, pétalas brancas.

Foi coletada com botões e flores a partir de março/abril até julho. Frutificação plena a partir de junho/julho.

Categoria IUCN (1994): Vulnerável. Espécie ameaçada, devido à devastação na área de distribuição da espécie. Não foi mais encontrada, desde as coleções históricas de Langsdorff e Schott 5635, nas margens dos rios Paraíba e Paraíbuna, divisa entre Rio de Janeiro e Minas Gerais. A área de distribuição de Bauhinia fusconervis estaria restrita a poucas localidades de Minas Gerais (ver no material examinado, em Vaz, 2001).

O material Gardner 5444 (K!, OXF!, foto $\mathrm{RB})$, procedente do Corcovado, na cidade do Rio de Janeiro, com hipanto e coluna estaminal internamente glabros foi identificado erroneamente por Bentham (1870) como $B$. fusconervis e, foi citado como material examinado sob B. fusconervis. Este material foi revisado, aqui, como $B$. longifolia s. lat. Bauhinia fusconervis, apresenta região distal do hipanto e coluna estaminal internamente seríceo-tomentosa, e não glabérrimos, como cita a descrição de Bentham (1870), feita 
provavelmente com base no espécime Gardner 5444. De lá para cá, espécimes de $B$. longifolia procedentes dos estados do Rio de Janeiro e Minas Gerais têm sido erroneamente identificados nas coleções de herbário, como B. fusconervis (ver caracteres diferenciais no quadro abaixo e também Mendonça-Filho (1996:33).

B. sellowiana foi tratada por Bentham (1870) como sinônimo de B. cuiabensis. (=B. ungulata $\mathrm{L}$. s. lat.). $\mathrm{O}$ exame da fotografia do tipo (espécime frutífero) e de coleções de mesma região mostrou que a flor de $B$. sellowiana é semelhante à de $B$. fusconervis e não apresenta botão clavado, não costado; pétalas estreitamente lanceoladas e coluna estaminal internamente barbada, como ocorre no complexo $B$. ungulata (= B. cuiabensis s. str.).

Bauhinia fusconervis é próxima de $B$. pulchella com a qual forma um complexo de difícil delimitação na área de sobreposição de distribuição no estado de Minas Gerais (tabela2).

17. Bauhinia gardneri Bentham, in Martius, Fl Bras. 15(2): 186. 1870. - Tipo. Brasil, Goiás: "Mission of Douro", out. 1839 (fr), Gardner 3123 (K, lectótipo, fotografia RB!; isolectótipos, BM!, OXF!, W!, fotografia RB ex B).

Subarbusto com xilopódio ou arbusto, 0,6 a 0,9m de altura. Entrenó distal 7-11 cm comp. Folhas bilobadas, lâmina 10-15x12,5-16,2 cm, coriácea; base profundamente cordada a lobada (lobos sobrepostos no material examinado), 911- nérvea, nervura marginal inconspícua, lobos concrescidos em 2/3 a 3/4 do comprimento total, suborbiculados, orientação (não aplicável nos lobos muito curtos) até um pouco divaricada, ápice arredondado, face superior glabra, nervuras impressas, face inferior pubescente a tomentela na região das nervuras primárias, tricomas glandulares presentes, não abundantes, nervuras primárias e secundárias proeminentes, terciárias um pouco proeminentes; pecíolo 1,5$2 \mathrm{~cm}$ compr., robusto, rufo-tomentelo. Estípulas ovado-lanceoladas, ca. $2 \mathrm{~mm}$ compr. Nectários extraflorais cônico-ovóides, $2 \mathrm{~mm}$ compr., exsertos. Inflorescência até $30 \mathrm{~cm}$ compr., longo-pedunculada; pedúnculo 7,5-13 $\mathrm{cm}$ compr.; eixo racemiforme, delgado, diminutoou evidentemente tomentelo; inflorescências parciais 2-floras a 3-floras; folhas alternifloras presentes, lâmina até $8,3 \times 10,5 \mathrm{~cm}$ até progressivamente reduzidas em direção ao ápice, brácteas foliáceas, rudimentares, às vezes com mucron presente, nectaríferas. Botões 7 $\mathrm{cm}$ na antese, lineares, ápice 5-obtuso reentrante, 5-costados, tomentelos, com tricomas glandulares. Flores na antese não examinadas, fragmentos com pedicelo $1-1,5 \mathrm{~cm}$ compr., bractéolas submilimétricas, hipanto cilíndrico, 1-1,5x0,6-0,7 cm, internamente desconhecido cálice fendido na antese em 2-4 lobos eretos, ondulados, espiralados, ca. $6 \mathrm{~cm}$ compr.; pétalas, não examinadas; estames desconhecidos, filetes internamente na junção com a coluna estaminal rufo-vilosos, coluna estaminal internamente não examinada; estigma não examinado; ovário rufo-tomentoso, estipe 2-3,5 cm compr., glabro. Legume deiscente, valvas imaturas $10,5 \times 1,5 \mathrm{~cm}$, glabras, estipe 2,5 cm cmpr.; lobos funiculares não vistos. Sementes não vistas.

Ocorre na Bolívia (col. Killen 1161, MO) e Brasil, no estado de Tocantins (Fig. 24). Segundo indice de topônimos (IBGE), a localidade Missões fica nas proximidades da Serra do Ouro, município de Dianópolis, folha SC-23, 47-12b; e o município de Arraias fica na folha SD-23,47-13d. Com cerca de 0,6 m de altura (Gardner 3123), ou cerca de $0,9 \mathrm{~m}$ (Gardner 3696). Habita em campos elevados. Subarbusto xeromórfito produzindo novos caules folhosos, a partir de um sistema subterrâneo e florescendo em campos cerrados após queimadas recentes.

Espécimes com botões e flores em setembro e outubro.

Difere do complexo B. holophyllalongifolia-rufa, por apresentar a base dos filetes rufo-vilosa.

18. Bauhinia goyazensis Harms, Bot. Jarhb. 33(72):21. 1903. Tipo. Brasil. Goiás: Fazenda do Paranana, no campo, maio 1895, leg. Glaziou 
21012 (holótipo não localizado; isótipo K!; fotografias RB! ex K, ex F negativo 1582, NY negativo 1619).

Subarbusto com xilopódio ou arbusto. Entrenó distal 4,5-5 cm comprimento. Folhas bifolioladas a bilobadas, cada lobo ou folíolo 46x3-4 cm, subcoriáceo a coriáceo, base cordada, 4-5-nérveo, nervura marginal aplanada, foliolos livres ou lobos concrescidos em $1 / 7$ a $1 / 5$, raramente até $1 / 2$ ou mais do comprimento total, subreniformes a ovado-elíticos, divergentes, ápice arredondado a obtuso; face superior glabra, face inferior pubérula a quase glabra, esparsamente e inconspicuamente glandulosa, nervuras primárias pouco proeminentes, secundárias e terciárias pouco proemimentes a imersas; pecíolo 1-1,7 cm compr., delgado, rufo-tomentelo. Estípulas não vistas; nectários extraflorais subuliformes a rudimentares, 0,5 $1,0 \mathrm{~mm}$ compr. Inflorescência curtopedunculada; pedúnculo ca. $4 \mathrm{~cm}$ compr.; eixo racemiforme geralmente duplo e ramificado, devido a rebrotamento de gemas reprodutivas no terço inferior, delgado, rufo-tomentelo; inflorescências parciais 2-floras; folhas distais reduzidas a um mucron, ou ausentes e então, apenas brácteas folíaceas escamiformes, ovadas, submilimétricas a rudimentares, nectaríferas; nectários extraflorais subuliformes, ovóides a rudimentares e submilimétricos. Botões 6,5x0,3 cm na antese, lineares, ápice 5reentrante-agudo, 5-sub-costados a lisos, enérveos, tomentosos, com tricomas glandulares numerosos e apressos. Flores com pedicelo 1,3-2 cm compr., Harms (1903) às vezes um pouco maiores, bractéolas escamiformes, submilimétricas, hipanto cilíndrico, 1,5-1,8x0,4-1 cm, internamente irregularmente seríceo-tomentoso na região distal; cálice fendido na antese em 4-5, lobos reflexos, ondulados a retorcidos, ca. $4,5-5,5 \mathrm{~cm}$ compr.; pétalas lineares, ápice agudo, ca.3,5x0,1 $\mathrm{cm}$, externamente glabras; estaminódios 0 , estames 10, anteras iguais, lineares, não loceladas, filetes $3,8-5,5 \mathrm{~cm}$ compr., filetes alternipétalos, internamente tomentosos, coluna estaminal presente, apêndice ligular obsoleto, internamente seríceo-tomentosa, externamente glabra; gineceu 7-8 cm compr., estigma claviforme, ovário pubérulo, com tricomas glandulares, estipe $4 \mathrm{~cm}$ compr., glabro. Legume deiscente, valvas 12,5-17x1 cm, pubérulo a glabro, estipe 3-4 cm compr; ; lobos funiculares curto-emarginados. Sementes 5$8 \times 3,5-5 \mathrm{~mm}$.

Ocorre apenas no Brasil, estados de Goiás, Mato Grosso, Tocantins e no Distrito Federal (Fig. 24). As localidades de ocorrência registradas nas etiquetas dos materiais examinados, procedentes de Goiás, Tocantins e Distrito Federal pertencem às Folhas IBGE (1960):SD-22, SD-23 e SE-22. Em Mato Grosso, foi coletada apenas no distrito de Pedra Preta, Serra da Petrovina (Hatschbach 62835, MBM, RB). Habita também em campo rupestre, cerrado pedregoso ou cerrado com afloramentos de rocha (vários coletores e observações de campo em Goiás), floresta mesofítica (Anderson 6902).

Botões e flores nos espécimes coletados em maio, junho e julho. Frutos desenvolvidos em julho a outubro.

Segundo Vaz \& Marquete (1993) B. goyasensis é um sinônimo de B. pulchella Bentham, a qual é aqui considerada como espécie distinta, com base no caráter grau de concrescimento do lobos foliares.

Tabela 2 - Caracteres diferenciais entre B. fusconervis, B. longifolia e B. pulchella

\begin{tabular}{llll}
\hline Caracteres diferenciais & B. fusconervis & B. longifolia & B. pulchella \\
\hline Coluna estaminal (lado interno) & Tomentosa & Glabra & Tomentosa \\
Estipe & Glabro & Tomentoso a hirsútulo & Glabro \\
Folhas (comprimento) & Até $8 \mathrm{~cm}$ & Até $12-(17-20) \mathrm{cm}$ & Até $4,5 \mathrm{~cm}$ \\
\hline
\end{tabular}

Rodriguésia 54 (83): 55-143. 2003 
19. Bauhinia grandifolia (Bongard) Steudel, Nom. Bot. ed.2, 1:191 (err. tipogr. 291). agosto, 1840. - Pauletia grandifolia Bongard, Mem. Acad. Imp. Sci. St. Petersb., ser. 6, Sci. Math. 4:130. tab.5, Fig. 3 (folha). 1836. - Tipo. Brasil. Amazonas: "in fruticetis siccis prope Borba", jul 1828 (fl), Riedel 1293 (holótipo LE, fotografias $\mathrm{BAB}$ !, RB!).

Arvoreta ou arbusto. Entrenó distal 2-5 cm comprimento. Folhas bilobadas, lâmina 13$21 \times 10-14 \mathrm{~cm}$, cartácea ou subcoriácea, base subtruncada a emarginada ou levemente cordada, 7- a sub-9-nérvea, nervura marginal infranerviforme, lobos concrescidos em menos de 1/3 do comprimento total, ovado-oblongos, paralelos a convergentes, ápice curtamente acuminado; face superior glabra, nervuras secundárias impressas, face inferior pilosa a hirsuta na região das nervuras primárias, inclusive nas margens, tricomas glandulares escassos, nervuras primárias proeminentes, secundárias pouco proeminentes a imersas, terciárias imersas; pecíolo 0,8-1 cm compr., robusto, hirsuto, glabrescente. Estípulas não vistas; nectários extraflorais não vistos. Inflorescência até $25-33 \mathrm{~cm}$ compr., curtopedunculada; pedúnculo $4 \mathrm{~cm}$ compr.; eixo racemiforme, delgado, rufo-hirsuto; inflorescências parciais 2-floras; folhas opositifloras/alternifloras não vistas, brácteas foliáceas rudimentares. Botões $7 \times 0,7 \mathrm{~cm}$ na antese, clavado-acuminados, ápice não apendiculado, lisos, enérveos, viloso-hirtusulos, sem tricomas glandulares. Flores, pedicelo 0,2 $\mathrm{cm}$ compr., bractéolas rudimentares, hipanto cilíndrico-urceolado, 1,0-1,3x0,5-0,6 cm compr., internamente glabro; cálice fendido na antese em 3-5 lobos reflexos, retorcidos, ca.7,0 cm compr.; pétalas lineares-oblanceoladas, 6,07,5x0,2-0,3 cm, externamente glabras; estames férteis 10 (segundo Bongard, 1836), filetes ca.7,5 cm compr., hirsutos na base; coluna estaminal ca.1 $\mathrm{mm}$ de altura máxima, internamente esparsamente pilosa, externamente hirsuta; gineceu compr. desconhecido, estigma forma desconhecida, ovário hirsuto a tomentelo, estipe compr. desconhecido, pubérulo a glabrescentes. Legume deiscente, valvas 13,5-15,5x1,8-2 cm, pubérulo, estipe 2,5-3,0 cm cmpr.; lobos funiculares filiformes. Sementes 10x8 mm.

Ocorre apenas no Brasil, estados do Amazonas e Pará (Fig. 24). As localidades de ocorrência registradas nas etiquetas dos materiais examinados pertencem às Folhas IBGE (1960): SA-21, SA-20 e SB-21, ao longo dos rios Madeira, Tapajós, em floresta de terra firme e capoeirão.

Floresce de junho a dezembro, frutos agosto e outubro

Bauhinia grandifolia compartilha o mesmo tipo de venação nerviforme e tem botão floral com contorno semelhante ao de $B$. cinnamomea (tabela 1).

20. Bauhinia holophylla (Bongard) Steudel, Nom. Bot. ed.2, 1:191 (err.tipogr. 291). agosto 1840. - Pauletia holophylla Bongard, Mem. Acad. Imp. Sci. St. Petersb., ser. 6, Sci. Math. 4:129. tab. 5, Fig. 2 (folha). 1836.- Tipo. Brasil. Mato Grosso: "in sylvis siccis Serrado dictis prope Camapuã", (holótipo LE ?).

Pauletia dodecandra Bongard, Mem. Acad. Imp. Sci. St. Petersb., ser. 6, Sci. Math. 4:129.t.4, f.2. 1836. - Bauhinia dodecandra (Bongard) Steudel, Nom. Bot. ed 2, 191 sphalm. 291. agosto 1840. - Bauhinia rufa var. dodecandra (Bongard) Bentham in Martius, Fl. Bras. 15(2):187. 1870. - Pauletia rufa var. dodecandra (Bongard) Schmitz, Bull. Jard. Bot. Nation. Belg. 43(3-4): 392. 1973. - Tipo. Brasil. Mato Grosso: "in campis siccis Camapuensibus", out 1826, s/coletor (holótipo LE, fotografia RB! ex BAB). Sin. nov.

Bauhinia cordata Vogel, Linnaea 11:308. 1839. - Bauhinia rufa var. cordata (Vogel) Bentham in Martius, Fl. Bras. 15(2):187. 1870. - Pauletia rufa var. cordata (Vogel) Schmitz, Bull. Jard. Bot. Nation. Belg. 43(3-4): 392. 1973. - Tipo. Brasil. Minas Gerais: "pr. Pompeo fusa aliisq. locis", "mense dec. c. fl.” s.d.(fl), Sellow s/n (holótipo B, destruído, fotografias RB! ex K negativo 16423 e NY 1586, isótipos E-GL!). Sin nov. 
Figs: 16,17

Subarbusto com xilopódio ou arvoreta ou arbusto. Entrenó distal 3-7 cm comprimento. Folhas inteiras, lâmina (4,5-)-9,5-17x(3,0-)-6,5$13,5 \mathrm{~cm}$, coriácea, ovado-lanceolada a ovada ou suborbiculada, base amplamente cordadas a obtusas, ápice agudo a emarginado, às vezes subbilobado no mesmo ramo, 7-13- nérvea, nervura marginal inconspícua, face superior glabra, nervuras secundárias impressas, face inferior tomentela a densa-mente vilosa, tricomas glandulares abundantes ou não, nervuras primárias muito proeminentes, secundárias e terciárias pouco proeminentes; pecíolo 0,5-2,6 cm compr., médio, tomentoso. Estípulas lineares, ca.6 mm (seg. Bongard, 1836: 122 , ca.16 mm); nectários extraflorais subuliformes, ca.1 mm compr., exsertos. Inflorescência até $18 \mathrm{~cm}$ compr., curtopedunculada; pedúnculo 2-7,5 cm compr.; eixo racemiforme, robusto-anguloso, fuscotomentoso; inflorescências parciais 2-floras; folhas opositifloras às vezes presentes, lâmina ca. $4,5 \times 2 \mathrm{~cm}$ ou menores, brácteas foliáceas ovadas; nectaríferas. Botões $11 \times 0,6-0,7 \mathrm{~cm}$ na antese, pentagonais, ápice 5- reentrante, 5costados, tomentelos a tomentosos. Flores com pedicelo 1,5-2,5 cm compr., bractéolas 3 ovadolanceoladas, hipanto cilíndrico, 1-1,5x0,6-1 cm, internamente glabro; cálice fendido na antese em 4-5 lobos reflexos, ondulados a retorcidos e espiralados, 5,5-7 cm compr.; pétalas lineares, longamente acuminadas, $3-4,5 \times 0,1 \mathrm{~cm}$, externamente glabras; estaminódios 0 , estames 10 , anteras iguais, lineares, não loceladas, filetes 3,5-4 cm compr., filetes alternipétalos, glabros, coluna estaminal até $3 \mathrm{~mm}$ de altura máxima, apêndice ligular obsoleto, internamente glabra, externamente glabra; gineceu ca. $7 \mathrm{~cm}$ compr., estigma claviforme, ovário tomentoso, estipe, $3,5 \mathrm{~cm}$ compr., tomentoso. Legume deiscente, valvas $16-23,5 \times 1,5-2,1 \mathrm{~cm}$, piloso, estipe 3,5$4,5 \mathrm{~cm}$ compr.; lobos funiculares uncinadolobados. Sementes 10x6-9 mm.

Ocorre no Paraguai (rio Apa, Hassler 10988, W) e Brasil, estados de Goiás, Minas Gerais, Mato Grosso, Mato Grosso do Sul,
Paraná, Rondônia e São Paulo e Distrito Federal. (Fig. 24). As localidades de ocorrência registradas nas etiquetas dos materiais examinados pertencem às Folhas IBGE (1960): SD-20, SD-21, SD-22, SD-23, sendo SD-20, 60-13a limites norte e oeste; SE-21, SE-22, SE23, sendo SE-23, 44-20a o limite leste; SF-23, SF-22, sendo o ponto SF-22, 49-24b o limite sul. Habita em cerrado propriamente dito, campo cerrado, campo, cerradão, floresta estacional.

Subarbusto xeromórfito, desde $0,4 \mathrm{~m}$ até arbustiva ca. $2 \mathrm{~m}$, no campo e no cerrado aberto e perturbardo (maioria dos coletores e observação de campo em Brasília, reserva ecológica do IBGE). Arvoreta 3-4 m em cerradão, São Paulo (Amaral Jr. 124; Arbocz 107; Bertoni 18663, Ratter 4871, etc.). Apresenta raízes robustas, a casca da raiz internamente possui cor vermelho-vivo (Vaz et Marquete, 1993). Ramos e raque da inflorescência angulosos, entrenós em ziguezague.

Floração em novembro, dezembro e frutifica em janeiro até agosto.

B. holophylla faz parte de um complexo de espécies que compartilham o mesmo tipo de coluna estaminal rudimentar até $3 \mathrm{~mm}$ compr., interna e externamente glabra, com pétalas lineares e longamente acuminadas; botão floral desde anguloso-5-costado ou 15estriado a levemente costado e subcilíndrico; ramos jovens angulosos (tabela 1).

21. Bauhinia leptantha Malme, Ark. Bot. Stockh. 5(5):11. 1905. - Tipo. Brasil. Mato Grosso: Corumbá, dez 1902 (bt/fl), Malme II:2730 (lectótipo S!, designado por Vaz, 1995, isolectótipo R!).

Arvoreta ou arbusto. Entrenó distal 1 - 3 $\mathrm{cm}$. Folhas bilobadas, lâmina (2,5-3-)5 - $10 \mathrm{x}$ 3,5 - 7,8 cm, tenuemente cartácea, base arredondada a subtruncada, 7-9-nérvea, nervura marginal inconspícua (não proeminente, nem infra-nerviforme ou aplanada), lobos concrescidos em mais de $2 / 3$ do comprimento total, ovado-oblongos, paralelos, ápice 


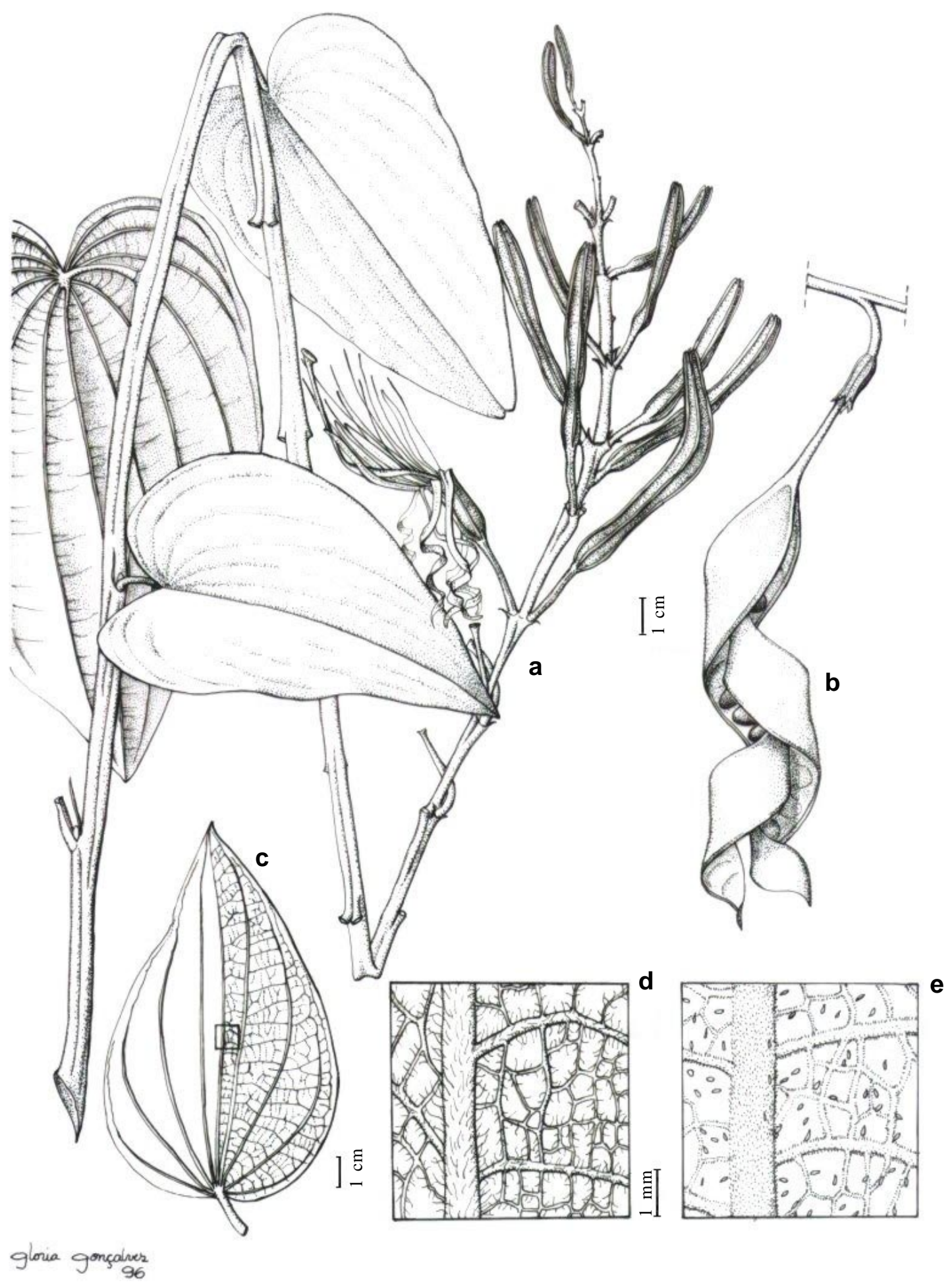

Figura 16 - Bauhinia holophylla (a, Marquete 317; b, Martinelli 367; c-d, Klein 2644; e, Vaz 917): a, ramo florífero; b, fruto; c, contorno foliar; d-e, detalhe do indumento na face inferior da folha, note a variação no tipo de indumento, viloso (d) ou tomentelo (e). Desenho G. Gonçalves, 1996. 


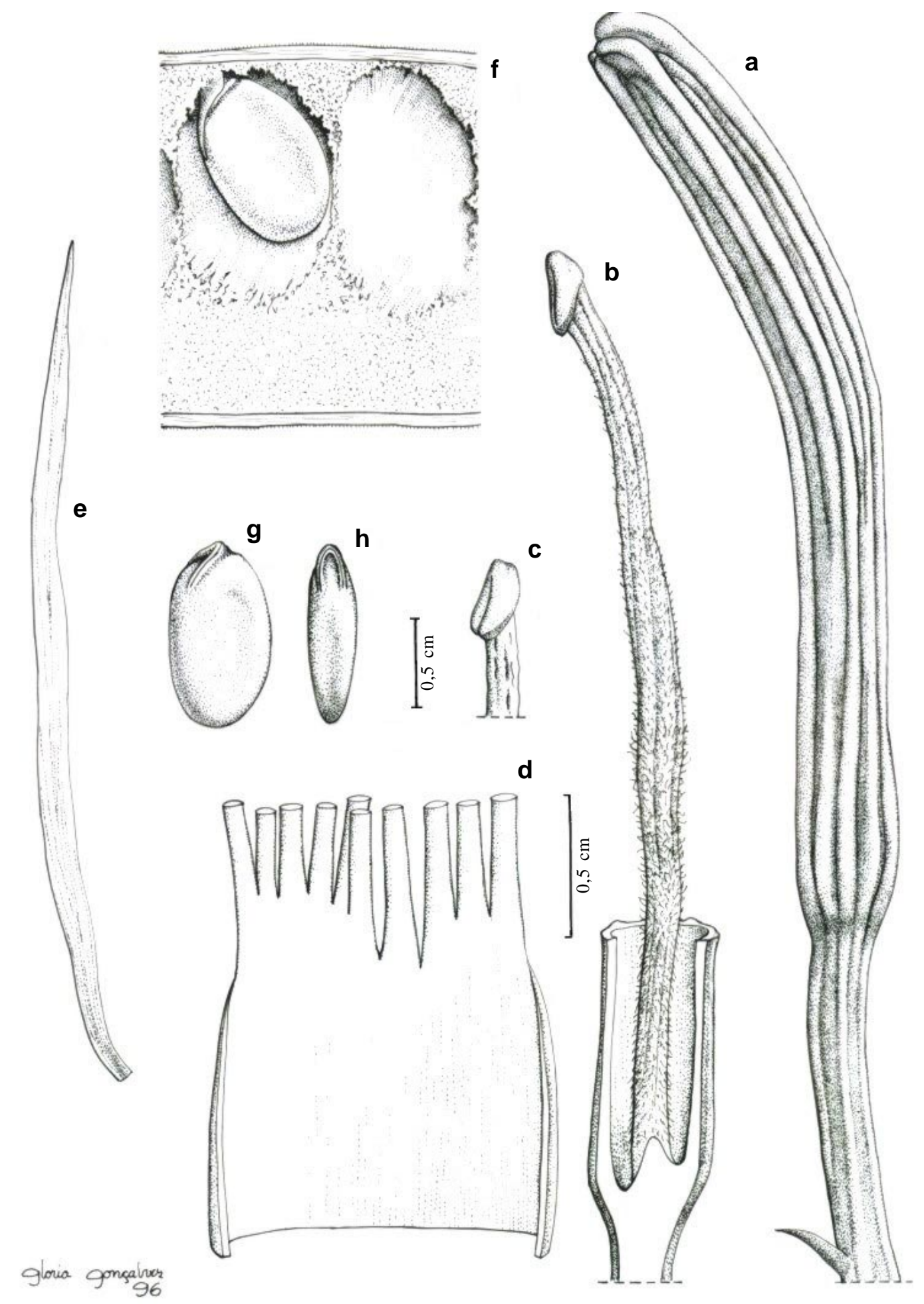

Figura 17 - Bauhinia holophylla (a-d, Marquete 317; e, Klein 2644; f-h, Martinelli 367): a, botão; b, gineceu, onde se vê a inserção do ginóforo no fundo do hipanto; c, detalhe do estigma; d, coluna estaminal em continuidade com a face interna do hipanto, ambos glabros; e, pétala na antese; f, detalhe da valva com semente; g, semente em vista lateral; $h$, semente vista de perfil. Desenho G. Gonçalves, 1996. 
acutiusculo a obtuso; face superior pilosa a glabra na nervura central impressa, nervuras secundárias não impressas, face inferior canopuberula especialmente nas nervuras primárias e/ou secundárias, tricomas glandulares apressos presentes, nervuras primárias proeminentes, secundárias pouco proeminentes, terciárias pouco proeminentes a imersas; ecíolo 1-1,8 cm compr., delgado, pubérulo. Estípulas lanceoladas a lineares 2 a 5 mm compr., caducas; nectários assovelados a rudimentares, ca. $1 \mathrm{~mm}$ ou submilimétricos. Inflorescência até $25 \mathrm{~cm}$ compr., curto-pedunculada; pedúnculo $1 \mathrm{~cm}$ de compr.; eixo racemiforme, delgado, pubérulo, tricomas branco-acinzentados; inflorescências parciais 2-floras; folhas alternifloras não vistas, reduzidas a pares de brácteas foliáceas, ca.1 $\mathrm{mm}$ compr. lineares ou rudimentares, nectaríferas; nectários subuliformes, ca. $1 \mathrm{~mm}$ a rudimentares. Botões 7x0,3-0,4 cm na antese, lineares, ápice 5-subcuspidado, setas rudimentares, 5-costados, canescentepubérulos, tricomas glandulares apressos e numerosos. Flores, pedicelo $2 \mathrm{~cm}$ compr., bractéolas lineares, ca. $2 \mathrm{~mm}$, hipanto cilíndrico a urceolado, 1,7-1,8x0,7-0,8 cm compr., internamente glabro; cálice fendido na antese em 2-3 lobos reflexos ou eretos, espiralados ou não, maior que $5,5 \mathrm{~cm}$ compr.; pétalas lineares, ca. 2,5 xca. $0,05 \mathrm{~cm}$, externamente glabras; estames fertéis 10 , estaminódios 0 , anteras iguais, lineares, não loceladas, filetes $5-6 \mathrm{~cm}$ compr., filetes alternipetalos glabros; coluna estaminal com altura máxima desconhecida, internamente com tricomas apresso-seríceos, externamente glabra; gineceu compr. desconhecido, estigma aplanado-escorrente, ovário pubérulo, estipe ca.3,5 cm compr., pubérulo. Legume deiscente, valvas 16x1,4-1,6 $\mathrm{cm}$, pubérulas, estipe $4 \mathrm{~cm}$ compr., lobos funiculares curto-triangulares. Sementes ca.6x6 mm.

Ocorre apenas no Brasil, estado de Mato Grosso do Sul, Corumbá (Fig. 24). Folha SD21, 58-19b, principalmente em lugares inundados na época chuvosa (col. Malme 2780) e floresta de "pé de serra", solo calcário.
Trata-se de um caso de endemismo restrito, com uma única população conhecida.

Bauhinia leptantha apresenta ramos lenticelados, pubérulos e cinzentos.

Floresce de outubro a dezembro. Frutos em abril e maio.

Categoria IUCN (1994): Vulnerável. Espécie ameaçada, devido à intensidade dos fatores adversos que afetam as populações existentes em termos de destruição de seu habitat natural.

B. leptantha é uma espécie pouco conhecida, quanto às afinidades taxonômicas.

22. Bauhinia longicuspis Spruce ex Bentham in Martius, Flora Brasiliensis 15(2): 185. 1870. - Tipo:Brasil. Amazonas: "prope ostium fluv. Caburés, dez 1851(fl), Spruce 1978, (holótipo $\mathrm{K}$, fotografia RB! ex NY negativo 1580).

B. bicuspidata Bentham in Martius, Flora Brasiliensis 15(2): 193.1870. B. longicuspis var. bicuspidata (Bentham) E. P. Lewis, Legumes of Bahia, Kew, p. 93.1987. - Tipo: Brasil, Amazonas: "in sylvis Yapurensibus prov. Alto Amazonas": Martius (holótipo M). Sin. nov.

Bauhinia holophylla var. paraensis Ducke, Arch. Jard. Bot. Rio de Janeiro 4:52.1925. - Bauhinia longicuspis var. paraensis (Ducke) Wunderlin, Ann. Missouri Bot. Garden 60 (2): 571. 1973. - Tipo. Brasil. Pará: Vila Braga, rio Tapajós, janeiro 1918(fl), Ducke s/n, (RB!, lectótipo aqui designado, MG 16909). Sin. nov.

Bauhinia stenocardia Standley, Tropical Woods 33 (12).1933. - Tipo. Brasil. Pará: Aramanahy, baixo Tapajóz, jan. 1932 (bt), Monteiro da Costa 238 (holótipo F, isótipo RB!). Sin. nov.

Arvoreta ou arbusto. Entrenó distal 2-4,5 $\mathrm{cm}$ comprimento. Folhas inteiras, lâmina 9$26,5 \times 3,5-15,5 \mathrm{~cm}$, tênue-cartácea a coriácea, largamente ovado-lanceolada a oblongolanceolada, base subtruncada a obtusa, ápice longamente acuminado a bífido até emarginado (col. Ferreira 5393; col. Sanaiotti 197), 7-9nérvea, até folhas bilobadas, lobos concrescidos 
em até $2 / 3$ do comprimento total, arqueadodivergentes, acuminados, nervura marginal inconspícua, face superior glabra ou pilosa na nervura central impressa, nervuras secundárias impressas, face inferior pubérula a esparsovilosa ou hirsútula, especialmente nas nervuras primárias e/ou secundárias, tricomas glandulares presentes, nervuras primárias muito proeminentes, secundárias mais ou menos proeminentes, terciárias pouco proeminentes; pecíolo 0,5-5 cm compr., delgado, pubérulo. Estípulas lineares, ca.5-7 mm compr., caducíssimas a rudimentares; nectários extraflorais cônico-ovóides, 1-2 mm compr., exsertos. Inflorescência até $25-60 \mathrm{~cm}$ compr., curto-pedunculada; pedúnculo 1,5-3,5 cm compr.; eixo racemiforme, delgado, pubérulo; inflorescências parciais 2-floras; folhas alternifloras ausentes, reduzidas a pares de brácteas nectáriferas, ca.2-4 mm compr., lineares ou rudimentares. Botões $12 \times 0,4 \mathrm{~cm}$ na antese, lineares, ápice 5-cuspidado ou subcuspidado, setas caducas a rudimentares, 5-costados em maior ou menor grau, tomentelos, com tricomas glandulares escassos. Flores com pedicelo 1,2-2 cm compr., brácteas segunda ordem e bractéolas lineares até rudimentares, hipanto cilíndrico a urceolado, 1-2x0,7-0,8 cm compr., internamente glabro; cálice fendido na antese em 2-3 lobos reflexos ou eretos, retorcidos ou não, ca. $5,5 \mathrm{~cm}$ compr.; pétalas lineares, 2,5-4x0,08 cm, externamente pubérulas a glabras; estaminódios 0 , estames 10 , anteras iguais, lineares, não loceladas, filetes 5,5-8 cm compr., glabros; coluna estaminal presente, $7 \mathrm{~mm}$ altura máxima, apêndice ligular ausente, internamente viloso-tomentosa, externamente glabra a pilosa na junção dos filetes; gineceu compr. desconhecido, estigma claviforme, um dos lados aplanado-escorrente, ovário tomentelo, estipe $4 \mathrm{~cm}$ compr., pubérulo a glabrescente do ápice para a base. Legume deiscente, valvas $12-22 \times 1,4-1,8 \mathrm{~cm}$, pubérulas, estipe 4-5 cm compr.; lobos funiculares filiformes. Sementes $12 \times 6 \mathrm{~mm}$.

Ocorre na Bolívia (Sperling \& King 6414, CTES), Peru (Foster 8687, MO), Venezuela
(Castillo 3394, MO) e Brasil, nos estados do Acre, Amazonas, Mato Grosso, Pará, Rondônia e Tocantins (Fig. 23). As localidades de ocorrência registradas nas etiquetas dos materiais examinados pertencem às Folhas IBGE (1960): NA-19, NA-20, NA-21, SA-20, SA-21, SB-20, SB-21, SB-22, SC-20, SC-21, SC-22, SD-20, SD-21 e SD-22. Em capoeira, floresta de terra firme, floresta estacional, floresta semidecídua, floresta de galeria mesofítica (Silva 4039), cerrado de Santarém (Kuhlmann, 1823), campo natural em Humaitá (Ferreira 5393), campo de pedregulho em Humaitá (Sanaiotti 197), campo do Tabua no Alto Tapajós (Egler 1319).

O hábito de arvoreta varia entre $6 \mathrm{~m} \mathrm{x} 8$ $\mathrm{cm}$ col. (Prance 15342) ou $7 \mathrm{~m}$ (Cid Ferreira 7400 ) até $12 \mathrm{~m}$ de altura (M.G. Silva 3441). O arbusto pode ter $1,5 \mathrm{~m}$ de altura, em campo de pedregulhos e bambus de Humaitá (Sanaiotti 197). O hábito de arbusto semiciófilo flexível, ca.1,8 m foi registrado na coleção M.A. Silva et al. 4039 e o de arbusto escandente e herbáceo na extremidade distal por vários outros coletores.

Floresce de outubro a março e frutifica junho a outubro.

Bentham (1870) descreveu B. longicuspis com folhas inteiras 7-9-nérveas, glabras ou face inferior foliar pubescente, entre outros caracteres e $B$. bicuspidata com folhas bilobadas 9-11-nérveas, face inferior foliar rufopubescente, entre outros. Há um gradiente de variabilidade quantos aos caracteres citados nas duas descrições referidas acima e, não se configurou uma delimitação precisa entre as citadas espécies, de modo que decidiu-se adotar B. longicuspis como uma espécie única. Alguns espécimes examinados coletados na região do rio Purus, como, por exemplo, Kuhlmann 902, Prance et al. 13649, Prance et al. 16397, apresentam folhas com ápice bífido, mas não chegam a configurar lobos divaricados, concrescidos em 2/3 como descrito para $B$. bicuspidata. Ficou caracterizada nesse caso uma gradação entre o tipo de folha inteira e a folha bilobada típica descrita para B. cuspidata. 
Por outro lado a separação entre $B$. longicuspis e B. longicuspis var. paraensis também era baseada em tipo de pilosidade dos ramos e do dorso da folhas (Ducke, 1925a:54), fracamente pubescente, hipanto 1,5-2 cm compr., ovário com indumento pouco espesso na primeira e dorso foliar pubescente, hipanto $1 \mathrm{~cm}$ compr., ovário com indumento espesso na segunda. No entanto, com o aumento das coleções na região amazônica, essas características não se mostraram consistentes.

Os espécimes coletados em mata de terra firme ou capoeira, no Amazonas, Acre, Rondônia (parte) e Pará (Oriximiná, Trombetas) apresentam as seguintes características em comum: folhas inteiras com ápice íntegro ou bífido até bilobadas em ca. de $1 / 3$ do comprimento total da lâmina, tenuemente cartáceas, junto com botões 5-cuspidados e com bractéolas lineares, quando em botão jovem e o indumento do dorso foliar é apresso, inclusive nas nervuras primárias até esparso-viloso nas nervuras primárias e secundárias. Esses materiais foram encontrados nas folhas $\mathrm{Na}$ 20, SA-20, SB-20, SC-20 e parte da SA-21, no oeste da Amazônia. Nos campos de Humaitá (AM), campos arbustivo e mata de terra firme ou capoeira do Pará e na florestas secas ou cerrado do Mato Grosso (Xavantina) tem folhas sempre inteiras, firme cartáceas a coriáceas, botões emarginados e bractéolas rudimentares, indumento do dorso foliar apresso e esparsoviloso nas nervuras principais até vilosotomentoso em toda a superfície. Esses materiais foram encontrados nas folhas SA-21, SA-22, SB-21, SB-22, SD-20, SD-21, SD-22. Os espécimes de Humaitá ofereceram um gradiente mata terra firme (Brandtjes 100501) para os campos naturais (cols. Cid Ferreira 5393, Sanaiotti 197), o primeiro de mata de terra firme, com folhas inteiras acuminadas, tenuemente cártáceas, os demais com folhas também inteiras, porém largamente ovadas, ápice agudo a obtuso ou emarginado, firme cartáceas a coriáceas.

Bauhinia longiscuspis compartilha com B. dubia o mesmo tipo de coluna estaminal, estigma e apresentam flores com filetes maiores que o dobro do comprimento da pétalas. No estado do Pará as duas espécies são en-contradas na área correspondente à folha SA-22 $\left(48^{\circ}-54^{\circ} \mathrm{Wx} 0^{\circ}-4^{\circ} \mathrm{S}\right)$. Também as coleções da Serra dos Carajás, folha SB-22, deixam dúvidas quanto à separação entre as referidas espécies.

23.Bauhinia longifolia (Bongard) Steudel, Nom. Bot. ed.2, 1:191 (err.tipogr. 291). ago 1840. - Pauletia longifolia Bongard, Mem. Acad. Imp. Sci. St. Petersb., ser. 6, Sci. Math. 4:122. tab.7, Fig. 2 (folha).1836. - Tipo. Brasil. Mato Grosso: Cuiabá, Riedel s/n (holótipo LE).

Bauhinia geminata Vogel, Linnaea 13:305. 1839. - Tipo. Brasil. "Brasilia meridionalis"; sem data (fl), Sellow s/n $\mathrm{n}^{\circ}$ (holótipo B, destruído, fotografia RB! ex F negativo 1580; isótipos não localizados). Sin nov.

Bauhinia obtusata Vogel, Linnaea 13:305.1839. - Tipo. Brasil. Minas Gerais. "pr. Marianna", s/data (fl), Sellow 5428 (B, destruído, fragmento do holotipo F!, fotografia RB! ex F negativo 1600). Sin. nov.

Bauhinia recurva Cowan, Contrib. Sci. Los Angeles County Mus. 13:10.Fig.4. 957.Tipo. Brasil. Goiás: São João da Aliança, região da Chapada dos Veadeiros, rodovia ao norte de São João da Aliança km 19-19,5; 47³0'14³0', abr 1956 (fl), E.Y. Dawson 14387 (holótipo R!, isótipo NY!). Sin. nov.

Arvoreta ou arbusto. Entrenó distal 2-5 cm compr. Folhas bilobadas, lâmina (4- 5,5)9,5$11,5(-17,5) \times(1,5-) 4,4-10,5(-12,5) \mathrm{cm}$, tênuecartácea a subcoriácea, base de obtusa a subtruncada até emarginada, (7-)9-11-(13-) nérvea, nervura marginal inconspícua, lobos concrescidos em 1/3 a 2/3 do comprimento total, ovado-lanceolados a ovado-oblongos, paralelos a convergentes ou divergentes, ápice agudo, raramente obtusiusculo, face superior glabra, exceto na nervura principal pilosa, face inferior apresso-pubescente a hirsútula, tricomas glandulares escassos ou abundantes, nervuras primárias muito proeminentes, secundárias pouco proeminentes, terciárias pouco 
proeminentes a imersas; pecíolo 1-2,5 cm compr., delgado, viloso a tomentelo, glabrescente. Estípulas ovadas a ovadolanceoladas, 1-4 $\mathrm{mm}$ a rudimentares, submilimétricas; nectários extraflorais subuliformes, ca.1 $\mathrm{mm}$ compr., exsertos. Inflorescência até $20 \mathrm{~cm}$ compr., curtopedunculada; pedúnculo $0,5-2,5 \mathrm{~cm}$ compr.; eixo racemiforme, tomentelo; inflorescências parciais 2-floras; folhas opositifloras às vezes presentes, lâmina ca.5-6,5×2,7-3,2 cm ou menores, brácteas foliáceas ovadas com mucron, nectaríferas. Botões 10x0,6 cm na antese, subclavados, ápice apiculado, 15estriados a 5-subcostados, tomentelos, com tricomas glandulares. Flores com pedicelo 1,22,5(-4) cm compr., bractéolas 3 escamiformes, 1-3 mm; hipanto cilíndrico, 1,3-3,5x0,7-1,2 cm, internamente glabro; cálice fendido na antese em 4-5 lobos reflexos, ondulados a retorcidos e espiralados, 4-6 cm compr.; pétalas lineares, longamente acuminadas, 2,8-4x0,1 cm, externamente tomentosa, com tricomas esparsos e raras tricomas glandulares até glabras; estaminódios 0 , estames 10 , anteras iguais, lineares, não loceladas, filetes $4,5-5,5 \mathrm{~cm}$ compr., filetes glabros, coluna estaminal até 2 $\mathrm{mm}$ de altura máxima, apêndice ligular obsoleto, internamente glabra, externamente glabra; gineceu 8-10 cm compr., estigma claviforme, ovário tomentoso, estipe $3,8-5 \mathrm{~cm}$ compr., tomentoso. Legume deiscente, valvas 17-24,5 x1,7-1,9 cm, piloso, estipe $4 \mathrm{~cm}$ compr.; lobos funiculares uncinado-lobados. Sementes 10x 6 $\mathrm{mm}$.

Ocorre na Bolívia (col. Guillen \& Coria 1332, MO), Paraguai (col. Hassler 10210, W), Peru (cf. Macbride, 1943) e Brasil, nos estados da Bahia, Espírito Santo, Goiás, Minas Gerais, Mato Grosso, Mato Grosso do Sul, Pará (sul do Pará), Paraná, Rio de Janeiro, Rondônia, São Paulo e no Distrito Federal (Fig. 25). Habita em florestas de galeria (ciliares) em domínio de cerrado, ou florestas mais úmidas e de encosta, na mata Atlântica do Rio de Janeiro, Minas Gerais e Espírito Santo, até a mata higrófila sul-bahiana, predominantemente na orla de floresta ou em áreas degradadas (Hatschbach 69807). Habita em área de transição floresta-cerrado, em solo arenoso com deposição de matéria orgânica, cerrado aberto (Santos 58), floresta de encosta de serra, próxima a campo rupestre (Ganev 553). As localidades de ocorrência registradas nas etiquetas dos materiais examinados pertencem às Folhas IBGE (1960): SC-20, SD-20 (Rondônia); SD-21, SE-21, SF-21, SC-22 (Pará, Santana do Araguaia, limite norte da distribuição); SD-22, SE-22, SF-22, SG-22, SD23, SD-24, SE-24, SF-23, SF-24.

Os indivíduos de $B$. longifolia podem atingir porte arbóreo, por exemplo, árvore de $10 \mathrm{~m} \times 15 \mathrm{~cm}$, na mata de terra firme de Buerarema, na Bahia (cf. CMM 47, CEPEC); até árvore de $16 \mathrm{~m}$ x fuste mais ou menos 10 m, DAP $21 \mathrm{~cm}$ em Porto Seguro, Bahia (G.L. Farias 193, RB); mas geralmente são encontrados na forma de arvoreta, 3-8 m. Também, podem ser encontradas na forma arbustiva, com 1-3 m de altura, quando em vegetação em área aberta e adjacente à floresta, como na transição cerrado-floresta ciliar (observação de campo na Reserva Ecológica do IBGE, Brasília) e em outras áreas (vários coletores).

Botões e flores a partir de novembro e espécimes frutíferos coletados a partir de março a julho/agosto.

No estado de São Paulo é utilizada na arborização de cidades do interior.

Espécimes examinados procedentes do estado do Mato Grosso demonstram o gradiente de variação supostamente da floresta mais úmida para as áreas de floresta mais seca, com folhas cartáceas da floresta mais úmida até subcoriáceas e mais altamente conadas. Quando os espécimes apresentam folhas mais coriáceas, e obtusiúsculas, fica mais difícil distinguir $B$. rufa de $B$. longifolia que, talvez não passem de formas distintas de uma mesma espécie.

A conceituação de B. longifolia (sensu Bongard, 1836: 122, sensu Bentham, 1870: 192) é ampliada aqui, abrangendo espécimes com 
botões claviformes, 15-estriados, robustos até subcilíndricos, levemente costados e menos robustos; folhas subcoriáceas a tênuecartáceas; pétalas glabras até externamente pilosas a tomentosas; estaminódios 0 , estames 10 , anteras pilosas e com tricomas glandulares. Bauhinia geminata, segundo a diagnose (Vogel, 1839:305), apresenta pétala é externamente tomentosa, porém este caráter não se mostrou consistente, quando associado com os outros caracteres diagnósticos, como folhas com lobos concrescidos em $1 / 2$ ou menos, divergentes e tenuemente cartáceos. Bauhinia obtusata, segundo a diagnose (Vogel 1839:305) e o tipo examinado, apresenta folhas bilobadas com lobos concrescidos em $2 / 3$ ou somente até a metade, medindo $3,5-5 \times 4,5-5 \mathrm{~cm}$. Este padrão não se confirmou ao exame das coleções posteriores, embora existam espécimes coletados, na localidade de Lavras (D.A. Carvalho s/n, RB 295591) e Caxambu (Duarte 3847), em Minas Gerais que se apresentam como arbustos intensamente ramificados e com folhas com estas dimensões. O tipo de Bauhinia recurva não difere da diagnose de B. longifolia (Bongard, 1836) a não ser pelas folhas menores $(10,5 \times 6-7,5 \mathrm{~cm})$, coriáceas, com lobos agudos (obtusos a obtusiusculos em $B$. longifolia); 9-nérveas (11-nérveas em $B$. longifolia); face inferior crispado-pilosula nas nervuras e veias (pubescente em B. longifolia), botões florais quase lisos (15-estriados em $B$. longifolia) e hipanto com $2,5 \mathrm{~cm}$ (ca. $1,8 \mathrm{~cm}$ em B. longifolia).

Ver afinidades taxonômicas de Bauhinia longifolia na tabela 1 .

24. Bauhinia longipedicellata Ducke, Arch. Jard. Bot. Rio de Janeiro 3: 105. 1922. - Tipo. Brasil. Pará: Pimental, rio Tapajoz, jun 1918 (fl), A. Ducke s/n (lectótipo aqui designado MG 17064!, isolectótipo RB 11140!).

Arvoreta ou arbusto. Entrenó distal 3-4 $\mathrm{cm}$ comprimento. Folhas curto-bilobadas, lâmina 12-16(-20)x7,5-12(-15) cm, cartácea ou subcoriácea, base de subtruncada ou arredondada até cordada, 9-11- nérvea, nervura marginal inconspícua, lobos concrescidos em mais do que $3 / 4$ até ca. de 14/15 do comprimento total, ovado-oblongos a elítico-oblongos, paralelos, ápice acutiusculo a obtuso; face superior pubérula a glabrescente, nervuras não impressas, face inferior vilosa em toda a superfície, inclusive nas nervuras, tricomas glandulares presentes, nem escassas, nem abundantes, nervuras primárias proeminentes, secundárias mais ou menos proeminentes e terciárias pouco proeminentes; pecíolo (1,52-3(4,5-) cm compr., delgado, viloso-tomentoso. Estípulas ovado-lanceoladas, $2 \times 1 \mathrm{~mm}$, quebradiças a rudimentares ou ausentes; nectários extraflorais subuliformes, base estreitamente ovada, $3 \mathrm{~mm}$ compr., exsertos. Inflorescência até $14 \mathrm{~cm}$ compr., curtopedunculada; pedúnculo $1,5 \mathrm{~cm}$ compr.; eixo racemiforme a subcorimbiforme, robusto, tomentoso; inflorescências parciais 2-floras; folhas subopositifloras presentes na base da inflorescência, inteiras, elíticas, menores e mais estreitas, 9-10x3,5-6 cm, brácteas foliáceas ovado-lanceoladas, caducissimas ou quebradiças; nectários rudimentares ou caducos. Botões 9,5x0,8-0,9 cm na antese, ou mais largos, subclavados, ápice liso, não reentrante nem apiculado, 15-costados, tomentosos, com tricomas glandulares. Flores abertas não examinadas, pedicelo $3-4,5 \mathrm{~cm}$ compr. (flores passadas), bractéolas ovadoacuminadas, 2-4 mm compr., hipanto cilíndrico, 2-3x1,2-1,5 cm, internamente glabro; cálice fendido na antese em 4-5 lobos involutos, 4-6 cm compr. (segundo Ducke, 1922); "petala angustissime linearia, acutissima glabra calice longiora at sub anthesis involuta" (segundo Ducke, 1922); filetes alternipétalos, internamente na junção com o hipanto glabros; coluna estaminal rudimentar, submilimétrica, apêndice ligular ausente, interna e externamente glabra; gineceu compr. desconhecido, estigma obliquo-subcapitado-claviforme, ovário tomentelo, estipe compr. desconhecido, tomentelo. Legume deiscente, valvas 22$29 \times 1,6-1,9 \mathrm{~cm}$, tomentelo, glabrescente, estipe ca. $4,5 \mathrm{~cm}$ compr.; lobos funiculares uncinado- 
lobados. Sementes maduras não examinadas. Ocorre apenas no Brasil, estado do Pará e Rondônia (Fig. 25). As localidades de ocorrência nos rios Tapajós e Araguaia pertencem às Folhas IBGE (1960): SA-21, SA22, SB-22 e SC-22 e, no estado de Rondônia à Folha SC-20. Habita em floresta de terra firme.

Trata-se de uma espécie ainda pouco conhecida e raramente presente nas coleções.

Botões de fevereiro a junho. Frutifica em julho/agosto; frutos passados e rebrotação em novembro.

Bauhinia longipedicellata compartilha com B. aureopuntata vários caracteres, por exemplo, coluna estaminal rudimentar e filetes e hipanto interna- e externamente glabros, assim como com todo o complexo B. longifolia (tabela 1).

25. Bauhinia malacotricha Harms, Bot. Jahrb. 33 (72):22.1903. - Tipo: Brasil. Goiás: Chapadão dos Veadeiros, jan 1891 (fl), Glaziou 21016 (holótipo B, perdido; isótipo P!, fotografias RB! ex F negativo 1595; ex NY negativo 1621).

Arbusto. Entrenó distal 5,5 cm comprimento. Folhas bilobadas, lâmina $6-7 \times 7-8 \mathrm{~cm}$ ou mais largas (Harms, 1903), coriácea, base profundamente cordada e/ou com lobos basais sobrepostos (Harms, 1903), 9-13 nérvea, nervura marginal inconspícua, lobos concrescidos até $1 / 2$ a $2 / 3$ do comprimento total, largamente elíticos a orbiculados, paralelos ou um pouco divergentes, ápice arredondado; face superior glabra, nervação um pouco impressa, face inferior rufo-tomentosa a maciamente denso-vilosa, tricomas glandulares presentes, nervuras primárias muito proeminentes, secundárias e terciárias proeminentes; pecíolo 0,8-1,2 cm compr., robusto, rufo-velutino. Estípulas não vistas, nectários extraflorais perfeitos não vistos. Inflorescência comprimento desconhecido, curto-pedunculada; pedúnculo $2 \mathrm{~cm}$ compr.; eixo racemiforme, nem delgado, nem robusto, densamente rufovelutino; inflorescências parciais 2-floras/3floras; folhas opositifloras/alternifloras não vistas, brácteas foliáceas não vistas. Botões 8,5$9 \times 0,6 \mathrm{~cm}$ na antese, pentagonais, ápice reentrante-obtuso, 5-costados, rufo-velutinos, com tricomas glandulares. Flores com pedicelo 1,2-1,8 cm compr., bractéolas escamiformes, submilimé-tricas, hipanto cilíndrico, 2x0,6-0,8 $\mathrm{cm}$, internamente tomentoso-viloso na região distal; cálice fendido na antese em 4-5 lobos reflexos, um pouco ondulados a retorcidos, não espiralados, 3-5 cm compr.; pétalas lineares, 34x0,1 cm, externamente glabras, estaminódios 0 , estames 10 , anteras iguais, lineares, não loceladas, filetes $4-5 \mathrm{~cm}$ compr., filetes pilosos, coluna estaminal rudimentar até ca.1 $\mathrm{mm}$ altura máxima, apêndice ligular ausente, internamente velutino-tomentosa, externa-mente pilosa; gineceu ca 7,5 cm compr., estigma cla-viforme, ovário piloso com tricomas glandulares, estipe $3,5 \mathrm{~cm}$ compr., com tricomas glandulares esparsas. Legume deiscente, valvas 10,5-17x $1,1-1,2 \mathrm{~cm}$, estipe $3,6-3,8 \mathrm{~cm}$ compr. Sementes $0,6-0,8 \times 0,4-0,5 \mathrm{~cm}$.

Ocorre apenas no Brasil, estado de Goiás e Brasília (Fig. 25). As localidades de ocorrência pertencem às Folhas IBGE (1960): SD-23 e SD-22, meridianos 47 e 48 e latitude 14 a 16. Habita em margem da mata de galeria com campo cerrado ou campo sujo e, em vegetação campestre (col. Vaz 888).

Floresce a partir de janeiro e frutifica de julho a dezembro.

Trata-se de uma espécie ainda pouco conhecida e raramente presente nas coleções.

$B$. malacotricha compartilha com as outras espécies do complexo B. pulchella/B. curvula/B. dumosa a coluna estaminal internamente tomentosa na região distal, mas difere por apresentar botões subclavados, anguloso-costados, fortemente ferrugíneovelutinos, entre outros caracteres. Devido ao indumento tomentoso-velutino da face inferior pode ser confundida como B. dumosa, porém difere pelo tipo da forma do lobo foliar quase reniforme, e mais maciamente velutino.

O epíteto específico se refere ao tipo de indumento (malaco $=$ macio ao toque; Stearn, 1973: 276). 
26. Bauhinia malacotrichoides Cowan, Contr. Sci. Los Angeles County Mus. 13:8, Fig. 3. 1957. - Tipo: Brasil. Goiás: 21 km norte de S. João da Aliança, região da Chapada dos Veadeiros, abr. 1956 (bt), leg. Dawson 14293, (holótipo R!, fotografia $R B$ !).

Subarbusto com xilopódio. Entrenó distal $5-13 \mathrm{~cm}$ comprimento. Folhas bifolioladas, cada folíolo 3-4x1,7-2,6 cm (distais), 7-8x4,5-5,5 cm, coriáceo, largamente eltítico a reniforme ou perorbiculado, divaricado a revertido (de cabeça para baixo nas exsicatas), livres, ápice obtuso a arredondado, 4-5-nérveo, nervura marginal aplanada; face superior glabra, face inferior cano-pubescente a pubérula e ferrugíneo-viscídula ou seja com tricomas apressos entremeados com tricomas viscídulos, os quais ocorrem em maior concentração nas nervuras primárias, tricomas glandulares presentes, nervuras primárias proeminentes, secundárias e terciárias pouco proeminentes a imersas; pecíolo 0,8-1 cm compr., robusto, tomentelo. Estípulas rudimentares, submilimétricas a ausentes; nectários extraflorais subuliformes, ca. $1 \mathrm{~mm}$ compr. Inflorescência até $28 \mathrm{~cm}$ compr. (holótipo), mas geralmente pauciflora com até 8 botões simultâneos, longo pedunculada; pedúnculo ca.8-16 cm compr.; eixo racemiforme (holótipo) a subcorimboso, delgado, tomentelo a glabrescente; inflorescências parciais 2-floras; folhas opositifloras/alternifloras não vistas, brácteas foliáceas mucroníferas rudimentares, nectários extraflorais não vistos (rudimentares). Botões 8,5x0,7 cm na antese, lineares, ápice obtuso a agudo-apiculado, 5-costados quando jovens, viscídulos, tricomas glandulares. Flores com pedicelo ca.2-2,5 cm compr., bractéolas escamiformes, ca.1-2 mm, hipanto cilíndrico $1,2 \times 0,7-0,8 \mathrm{~cm}$ compr., internamente tomentoso na região distal; cálice ca.5,5 cm compr.; pétalas lineares ca. $3,5 \times 0,1 \mathrm{~cm}$, externamente glabras; estaminódios 0 , estames 10, anteras iguais, lineares, não loceladas, filetes ca. $4 \mathrm{~cm}$ compr., filetes glabros, coluna estaminal presente, 3-5 $\mathrm{mm}$ altura máxima, apêndice ligular ausente, internamente seríceo- tomentosa, externamente glabra; gineceu 6,5 cm compr. (3,8 cm, Cowan, 1957), estigma claviforme, ovário tomentoso a pubescente, com tricomas glandulares, estipe $3 \mathrm{~cm}$ compr. (1,5 $\mathrm{cm}$, Cowan, 1957), glabro. Legume deiscente, valvas 9-11x1,5-1,8 cm, pubescente, estipe 3,5 cm compr., lobos funiculares uncinado-lobados. Sementes não vistas.

Ocorre no Brasil, estado de Goiás (Fig. 25). As localidades de ocorrência registradas pertencem à Folha IBGE (1960):SD-23. Habita em campo limpo queimado recentemente (Silva 2381); campo limpo arenoso (Silva 1993). A altura varia entre $0,5-1 \mathrm{~m}$ de altura e os indivíduos formam moitas. Folíolos bipartidos, pecíolo bifurcado no ápice em alguns espécimes.

Floresce em abril, maio, setembro, novembro. Espécime frutífero outubro, novembro, março e maio.

Trata-se de um endemismo restrito ao município de Alto Paraíso de Goiás e estradas dos arredores e Parque Nacional da Chapada dos Veadeiros.

Bauhinia malacotrichoides é uma espécie campestre muito característica pela forma dos folíolos perorbiculados, inteiramente separados e inseridos cada um diretamente no pecíolo, face inferior com tricomas curtos apressos, em maior ou menor densidade, entremeados com tricomas víscidos até quase glabra e apenas glandulosa. O porte subarbustivo, a inflorescência pauciflora, o botão floral ferrugíneo-costado e com coluna estaminal internamente tomentosa aproxima esta espécie de B. malacotricha. Esta última, porém, possui folhas bilobadas, lobos concrescidos até a metade ou mais e face inferior tomentosa a vilosa.

27. Bauhinia membranacea Bentham in Martius, Fl. Bras. 15(2):187. 1870.- Tipo. Brasil. Goiás: "in sylvis humidis ad radices Serra de Santa Brida" 1840 (bt/fr), Gardner 3695 (holótipo não localizado, fotografia A!, ex NY negativo 1589, isótipo OXF!).

Arbusto. Entrenó distal $3 \mathrm{~cm}$ 
comprimento. Folhas inteiras até bilobadas, lâmina 14,7-16x12-13 cm, tenuemente cartácea, base subtruncada, 9-11-nérvea, nervura marginal inconspícua, lobos concrescidos em mais de 2/3 do comprimento total, largamente ovados a ovado-oblongos, paralelos, ápice obtuso; face superior pilosa na nervura central impressa, nervuras secundárias não impressas, face inferior pubérula, especialmente nas nervuras primárias e/ou secundárias, tricomas glandulares apressos e esparsos, nervuras primárias proeminentes, secundárias pouco proeminentes, terciárias pouco proeminentes a imersas. Pecíolo 3-4 cm compr., delgado, pubérulo. Estípulas rudimentares, submilimétricas; nectários rudimentares, ca.0,5 $\mathrm{mm}$ comprimento. Inflorescência comprimento desconhecido, curto-pedunculada; pedúnculo 2,5-3 cm compr.; eixo racemiforme, delgado, fulvo-tomentelo; inflorescências parciais 2floras; folhas alternifloras não vistas, reduzidas a pares de brácteas foliáceas, ca. $2 \mathrm{~mm}$ compr. duplamente lineares ou rudimentares, nectáriferas. Botões até 9,5x0,4-0,5 cm na antese, lineares, ápice subatenuado e 5cuspidado, setas caducas, 5-costados, fulvo- ou cano-tomentelos, tricomas glandulares apressos e numerosos. Flores, pedicelo 1,2 cm compr., bractéolas lineares a rudimentares, hipanto cilíndrico a urceolado, $1,5 \times 0,5 \mathrm{~cm}$ compr., internamente glabro; cálice fendido na antese em 2-3 lobos reflexos ou eretos, espiralados ou não, ca.5,5 cm compr.; pétalas lineares, ca.2,53,5 x ca.0,05 cm, externamente glabras; estames não vistos; coluna estaminal não vista; gineceu compr. desconhecido, estigma não visto, ovário tomentelo, estipe ca. $3 \mathrm{~cm}$ compr., pubérulo. Legume imaturo, valvas 13,5-16x1,5$2,1 \mathrm{~cm}$, tomentelas ou viloso-tomentosas até esparso-vilosas, indumento às vezes canescentes; estipe 4-4,5 cm compr. Sementes não vistas.

Ocorre no Brasil, estados de Bahia, Goiás, Piauí e Tocantins (Fig. 27). As localidades registradas pertencem às Folhas IBGE (1960): SD-23 e SC-23. Provavelmente, há um erro ortográfico na localidade-tipo, que pode ser
Serra de Santa Brígida, que fica na folha SD23, 47-13b. Habita em cerrado e floresta úmida, no pé de serra (coleção tipo), floresta decídua de altitude (Harley 21707), na margem da floresta mesofítica alterada (Silva 4322), floresta semidecídua secundária (Gottsberger 1128167).

Os espécimes coletados apresentam ramos aplanados, lenticelados, quase glabros. Subarbusto (col. Nascimento 528).

Floresce em outubro, janeiro. Frutifica em março.

Categoria IUCN (1994): Vulnerável. Espécie ameaçada, devido a intensidade dos fatores adversos que afetam as populações existentes em termos de destruição de seu habitat natural.

No Piauí é utilizada como pastagem, principalmente por ovinos, seguidos dos bovinos e caprinos, que comem suas folhas (Nascimento 528).

28. Bauhinia platyphylla Bentham, in Martius, Fl. Bras. 15(2):185. 1870. Tipo. Brasil. Goiás: "inter Cavalcante et Conceição", s/d. (fl/fr), Burchell 8086 (holótipo K; isótipo P, fotografias RB! NY negativo 1581, F negativo 39861).

Arbusto ou subarbusto com xilopódio. Entrenó distal 2,5-3 cm comprimento. Folhas bilobadas, lâmina (4,5-)8-10x(5,3-)10,5 cm, crasso-coriácea, base profundamente cordada, 7-9-nérvea, nervura marginal inconspícua, lobos concrescidos em mais de 3/4 do comprimento total, suborbiculados, paralelos/divergentes (não aplicavel), ápice arredondado a subtruncado; face superior glabra, nervuras secundárias impressas, face inferior totalmente glabra, tricomas glandulares presentes, esparsas, nervuras primárias pouco proeminentes a imersas, exceto a nervura central proeminente, nervuras secundárias e terciárias imersas; pecíolo 10-25 mm compr., robusto, totalmente glabro. Estípulas não vistas, Bentham, (1870) pequenas ou rudimentares; nectários extraflorais cônico-ovóides a rudimentares, submilmétricos. Inflorescência até $12 \mathrm{~cm}$ compr., curto-pedunculada; pedúnculo $3 \mathrm{~cm}$ 
compr.; eixo racemiforme, delgado, glabro e glaucescente; inflorescências parciais 2-floras; folhas opositifloras, lâmina $3 \times 4 \mathrm{~cm}$, ou reduzidas a 1-2-brácteas foliáceas, às vezes com mucron intermediário, nectaríferas. Botões 9-13x0,5 cm na antese, lineares, ápice reentrante-agudo, lisos a levemente costados, com tricomas glandulares abundantes. Flores, pedicelo 2-4 cm compr.; bractéolas escamiformes submilimétricas; hipanto cilíndrico, $1,5-2,5 \times 0,5 \mathrm{~cm}$, internamente irregularmente hirsútulo-tomentoso na região distal; cálice fendido na antese em 3-5 lobos, reflexos, ondulados ou não a retorcidos, ca.57,5 cm compr.; pétalas lineares, ápice acuminado, 2-3,5x0,1 cm, externamente glabras; estaminódios 0 , estames 10 , anteras iguais, lineares, não loceladas, filetes 4,5-6 cm compr. , glabros, exceto os dois laterais alternipétalos; coluna estaminal com $6 \mathrm{~mm}$ altura máxima, apêndice ligular obsoleto, internamente seríceotomentosa, externamente glabra; gineceu $7 \mathrm{~cm}$ compr., estigma claviforme, ovário glabro, com tricomas glandulares, estipe 2,3-3 cm compr., glabro. Legume deiscente, valvas maduras não vistas, imaturas $10-15 \times 0,8-1 \mathrm{~cm}$ Bentham, (1870), glabro, estipe 3,5-4 cm cmpr.; lobos funiculares não vistos. Sementes não vistas.

Ocorre apenas no Brasil, estado de Goiás (Fig. 27). As localidades de ocorrência registradas pertencem às Folhas IBGE (1960): SD-22 e SD-23. Habita em afloramento rochoso de quartzito, solo branco (Vaz 601); campo rupestre com quartzo leitoso (Silva 2082). Altitude até $1540 \mathrm{~m}$ (Silva 2082).

Observações de campo e coleções indicam a forma de arbusto ou subarbusto com xilopódio, desde 07-1 m até 1,7 m de altura, não ramificado ou pouco ramificado. Ramos aplanados e glaucescentes, folhas verdeazuladas, crasso-coriáceas, totalmente glabras e botões ferrugíneos.

Botões e flores de dezembro a maio.

Categoria IUCN (1994): Vulnerável. Espécie ameaçada, devido a intensidade dos fatores adversos que afetam as populações existentes.
29. Bauhinia pulchella Bentham in Martius, Fl. Bras. 15(2): 190. tab 49. 1870. - Tipo. Brasil: Piaui: Oeiras, s/data (fl), Gardner 2150 (lectotipo $\mathrm{K}$ !, inédito, fotografia $\mathrm{RB}$, isolectotipos BM!, GRAH!, L!, MANCH!, OXF!, W!).

Bauhinia pulchella var. parvifolia Bentham in Martius, Fl. Bras 15(2):190. 1870. - Tipo: Brasil. Minas Gerais: distrito Minas Novas, s/data, leg. Martius s/n (síntipo M, fotografia RB! ex F 27954). Sin. nov.

Arvoreta ou arbusto. Entrenó distal 0,51,5 cm comprimento. Folhas bilobadas, lâmina 1-5,1 x1,2-6 cm, tênue cartácea a subcoriá-cea, base emarginada (subcordada) até cordada, 7 nérvea, nervura marginal aplanada, lobos concrescidos em mais de 3/4, raramente $1 / 2$ do comprimento total, elíticos a ovado-elíticos até suborbiculares ou obovados, paralelos, ápice arredondado a obtuso; face superior glabra, nunca pilosa ou vilosa, face inferior pubescente ou quase glabra até rufo-tomentela na região das nervuras primárias, tricomas glandulares presentes escassos, nervuras primárias pouco proeminentes, secundárias e terciárias pouco proeminentes a imersas; pecíolo $0,5-1,2 \mathrm{~cm}$ compr., delgado, tenuemente rufo-tomentelo. Estípulas rudimentares, submilimétricas; nectários extraflorais subuliformes, 0,5-1,0 mm compr., ou rudimentares e geralmente encobertos pelas estípulas. Inflorescência até $15 \mathrm{~cm}$ compr., curto-pedunculada; pedúnculo 0,5-1,5 cm compr.; eixo racemiforme, delgado, tenuemente rufo-tomentelo; inflorescências parciais 2-floras; folhas subopositifolias, lâmina 0,7-2x0,6-1,6 cm, ou reduzidas a um mucron, ou ausentes e então, apenas brácteas foliáceas escamiformes (ovadas), submilimétricas a rudimentares; nectários extraflorais subuliformes a rudimentares, submilimétricos. Botões $10-12 \times 0,2-0,3 \mathrm{~cm}$ na antese, lineares, ápice 5-reentrante-agudo, 5-subcostados a lisos, enérveos, cano-tomentelos, com tricomas glandulares numerosos e apressos. Flores com pedicelo 0,9-1 cm compr., bractéolas escamiformes, submilimétricas, hipanto cilíndrico, 1,1-1,3x0,4-0,7 cm, internamente 
irregularmente seríceo-tomentoso na região distal; cálice fendido na antese em 3-5, lobos reflexos, ondulados a retorcidos, 3,5-5,7 cm compr.; pétalas lineares, ápice agudo, $2 \times 0,05-$ $0,1 \mathrm{~cm}$, externamente glabras; estaminódios 0 , estames 10, anteras iguais, lineares, não loceladas, filetes 5-6 cm compr., filetes alternipétalos, internamente tomentosos, coluna estaminal presente, $8 \mathrm{~mm}$ altura máxima, apêndice ligular obsoleto, internamente seríceotomentosa, externamente glabra; gineceu $8 \mathrm{~cm}$ compr., estigma claviforme, ovário tomentelo, com tricomas glandulares, estipe $4 \mathrm{~cm}$ compr., glabro. Legume deiscente, valvas 9-10-17x0,7$0,9 \mathrm{~cm}$, pubérulo a glabro, estipe $2-4,5 \mathrm{~cm}$ compr.; lobos funiculares curto-emarginados. Sementes 5-8x3,5-5 mm.

Ocorre apenas no Brasil (Fig. 27). No nordeste ocorre na Bahia e limítrofes Goiás e Tocantins (Folha SD-23), Ceará, Maranhão e Piauí, Rio Grande do Norte (Folhas SB-23, SC23, SB-24 e SC-24). Na região centro-oeste, em Mato Grosso e Mato Grosso do Sul se estendendo até Rondônia (Folhas SC-21 e SD21, SF-22). Na região sudeste, em Minas Gerais (Folhas SD-23 e SE-23). Na região norte, ocorre no Pará (Folha ?). Habita em orla de floresta de galeria, floresta de encosta de serras nordestinas e capoeiras (vários coletores); campo rupestre (Hatschbach 65023), campos gerais, campo cerrado, cerrado, caatinga, carrasco $\mathrm{Na}$ Bahia, tem sido freqüentemente coletada em altitudes acima de 800 até $1.300 \mathrm{~m}$.

Apresenta hábito arbustivo com $0,4 \mathrm{~m}$ (M.A. da Silva 1747) ou, mais freqüentemente 1-3 m (outros coletores). Também, apresenta porte de uma arvoreta com $10 \mathrm{~m}$ x $8 \mathrm{~cm}$ diâmetro, na transição entre mata de cume de uma colina e capoeira, no Maranhão (Jangoux et Bahia 1057) ou com $3 \mathrm{~m} \mathrm{x} 5 \mathrm{~cm}$ diâmetro em São João dos Patos (D.P. Lima 13334). Apresenta folhas levemente discolores e cálice ferrugíneo (Martinelli 11190), ou folhas glaucas com venação ferrugínea na face inferior (Harley et Souza H50106).

Espécimes da Bahia e Minas Gerais, indicam plena floração nos meses de março/ abril e espécimes apenas frutíferos foram coletados em junho a novembro e, com frutos passados associados com a rebrotação em dezembro.

As coleções de Andrade-Lima, em Pernambuco, diferem da variedade típica por apresentar folhas menores que $2,54 \mathrm{~cm}$, enquanto que a variedade típica foi descrita como apresentando folhas entre 2,54 e 3,7 cm compr. Nestas coleções o tamanho de folha não se mostrou constante, assim como nos espécimes coletados posteriormente em Minas Gerais e, em outros estados de ocorrência, não foram encontrados outros caracteres que justificassem a manutenção destas duas variedades em $B$. pulchella, daí a sinonimização aqui proposta. Observou-se nos espécimes examinados que os ramos axilares curtos costumam apresentar folhas menores do que as dos ramos longos terminais.

B. pulchella faz parte de um complexo de espécies, incluindo B. fusconervis, $B$. dumosa e $B$. curvula e outras descritas posteriormente (tabela 1). Nesse conjunto $B$. pulchella é distinta pelas folhas curtamente bilobadas, indumento foliar na face inferior formado de tricomas curtos e apressos, até quase glabras, exceto nas nervuras primárias rufo-tomentelas em maior ou menor grau, nervuras secundárias e terciárias pouco conspícuas, e ainda pelo ovário tomentelo com tricomas glandulares.

Foi detectada, através dos espécimes examinados (cols Coradin 6064, Harley 16858 ou sphalm. 6858, Orlandi 354) uma população de B. pulchella com folhas bipartidas e folíolos ca.1,5-2x1-1,5 cm. Esta área de ocorrência fica na folha SC-24, longitude $41^{\circ} 10^{\prime}$ a $41^{\circ} 20^{\prime} \mathrm{W} x$ ca. $10^{\circ} \mathrm{S}$ latitude estado da Bahia. Numa área disjunta de ocorrência de Bauhinia pulchella (folhas SC-21/SD-21/SE-21) - nos estados do Mato Grosso, em mata alta de terra firme (col. Cordeiro 50) e Rondônia (coletor ?, RB 178933) - as coleções apresentam folhas maiores até $6 \times 5 \mathrm{~cm}$; lobos concrescidos em ca. de $1 / 2$ do comprimento total; e o estipe maior até $5 \mathrm{~cm}$ de comprimento. 
Na folha SF-22, no Mato Grosso do Sul, foram coletados espécimes (Gibbs 5482, Leitão Filho 2057 e outros coletados em Selvíria (Tiritan 50, 53; Tamashiro 16285 etc.) que apresentam folhas com indumento mais denso no dorso foliar.

30. Bauhinia rufa (Bongard) Steudel, Nom. Bot. ed.2, 1:192. agosto 1840, non Baker 1878. - Pauletia rufa Bongard, Mem. Acad. Imp. Sci. St. Petersb., ser. 6, Sci. Math. 4:123. 1836. - Tipo. Brasil. Minas Gerais: s/citação de localidade, s/coletor (holótipo desconhecido).

Bauhinia choriophylla Vogel, Linnaea 13:307.1839. Tipo. Brasil. Rio de Janeiro, s/data, Sellow s/n (holótipo B, destruído, fotografia RB!, negativo NY 1584, isótipo E - GL!).

Bauhinia intermedia Vogel, Linnaea 11:309. 1839. - Bauhinia rufa var. intermedia (Vogel) Bentham in Martius, Fl. Bras. 15(2):187. 1870. - Pauletia rufa var. intermedia (Vogel) Schmtz, Bull. Jard. Bot. Nation. Belg. 43(3-4):392.1973. - Tipo. Brasil. s/procedência, s/data (fr), Sellow (holótipo B, destruído, fotografia RB!, negativo NY 1585, isótipo E - GL!). Sin nov.

Arvoreta ou subarbusto com xilopódio ou arbusto. Entrenó distal 2- cm comprimento. Folhas bilobadas, lâmina $6-10,8 \times 5,4-10 \mathrm{~cm}$, coriácea, base de cordada a subtruncada, 9 11-nérvea, nervura marginal inconspícua, lobos concrescidos em $2 / 3$ a $3 / 4$ do comprimento total, ovado-oblongos, paralelos, ápice obtuso a subtruncado ou arredondado, raramente acutiusculo, face superior glabra, exceto na nervura principal pilosa, face inferior fusco- ou ferrugíneo-tomentosa a hirsútula, tricomas glandulares escassos, nervuras primárias e secundárias muito proeminentes, terciárias proeminentes; pecíolo 0,9-2 cm compr., robusto, viloso a hirsútulo-tomentoso. Estípulas lineares, 7-13x1 mm, até oblongas subagudas, $5 \times 2 \mathrm{~mm}$; nectários extraflorais subuliformes, ca. $2 \mathrm{~mm}$ compr., exsertos. Inflorescência compr. desconhecido, curto-pedunculada; pedúnculo 1,5-5 cm compr.; eixo racemiforme, hirsútulo; inflorescências parciais 2-3-floras; folhas opositifloras 4-6x4,5-5 cm ou menores até ausentes e, então com brácteas foliáceas linearlanceoladas, com mucron, nectaríferas. Botões $12 \times 0,5 \mathrm{~cm}$ na antese, pentagonais, ápice apiculado ou obtuso, 15-estriados a 5-costados, hirsútulos, com tricomas glandulares. Flores com pedicelo 1,5-3 cm compr., bractéolas 3 lineares, 1-3 mm; hipanto cilíndrico, (1-)1,3-3,5x (0,6-)0,7-0,9, internamente glabro; cálice fendido na antese em 4-5 lobos reflexos, ondulados a retorcidos e espiralados, ca.7,5 cm compr.; pétalas lineares, longamente acuminadas, 3,5-4,5x-0,1-0,2 cm, externamente glabras; estaminódios 0 , estames 10 , anteras iguais, lineares, não loceladas, filetes $4,5-6 \mathrm{~cm}$ compr., filetes glabros, coluna estaminal até 2 mm de altura máxima, apêndice ligular obsoleto, interna e externamente glabra; gineceu ca.8,5 $\mathrm{cm}$ compr., estigma claviforme, ovário tomentoso, estipe 3,5-4,5 cm compr., tomentoso. Legume deiscente, valvas $14-23 \times 1,7-2,5 \mathrm{~cm}$, piloso, estipe 3,5-5 cm compr.; lobos funiculares uncinado-lobados. Sementes 11x10 mm.

Ocorre apenas no Brasil, estados de Goiás, Minas Gerais e Distrito Federal (Fig. 26). As localidades registradas pertencem às Folhas IBGE (1960): SD-22, SE-22, SD-23, SE-23. Pode apresentar hábito de arvoreta colonizadora, em áreas florestais abertas e em recomposição (Vaz \& Marquete, 1993). Em Goiás e Minas, habita em campo rupestre, cerrado e floresta mesofítica, especialmente em áreas perturbadas limítrofes de floresta com cerrado/campo. No estado de Minas Gerais são arbustos ou arvoretas, em áreas serranas Serra do Cipó, Serra do Espinhaço, Serra do Cabral, Serra dos Inconfidentes, etc., em altitudes entre 900 e 1.600 metros (vários coletores). Os ramos são angulosos e robustos.

Floração a partir de setembro a janeiro e predomínio de frutos imaturos desde fevereiro até a plena frutificação em agosto.

O isótipo examinado de $B$. choriophylla apresenta folhas coriáceas, lobos oblongos, base profundamente cordada, 9-11-nérveas, lobos concrescidos em ca. de 3/4 da lâmina, ápice subtruncado - arrredondado, face inferior com 
nervação elevada até as nervuras terciárias ou quarternárias e fusco-tomentoso-hirsutas; com estípulas proximais lineares, $10 \mathrm{x} 1 \mathrm{~mm}$ até oblongas subagudas, $5 \times 2 \mathrm{~mm}$, nas folhas distais. Bractéolas lineares.

$\mathrm{O}$ isótipo examinado de $B$. intermedia apresenta folhas curtamente bilobadas, lobos concrescidos em ca. de 4/5, ápice arredondado a acutiúsculos, base levemente cordada a subtruncada; face inferior com nervação terciária um pouco menos elevada, e com indumento um pouco mais claro e velutino. As estípulas um pouco mais lanceoladas e as bractéolas pouco menores segundo o autor (Vogel 1839). O epíteto específico "intermedia" é uma referência às duas espécies descritas no mesmo trabalho (B. cordata e $B$. choriophylla). No próprio trabalho original, Vogel (1839) já reconheceu que estas espécies são bastante afins de $B$. rufa, cujo tipo não foi por ele examinado (ver informações adicionais sob B. holophylla).

Bentham (1870) considerou $B$. dodecandra na categoria de variedade de $B$. rufa. Aqui decidimos considerar $B$. dodecandra como sinônimo de $B$. holohylla, com base em diversos caracteres (ver discussão sob B. holophylla).

B. rufa distingue-se das espécies do complexo B. holophylla/B. longifolia por apresentar folhas coriáceas, curtamente bilobadas, obtusas a arredondado subtruncadas, parte superior levemente bulada e indumento ferrugíneo e velutino a hirsuto nos ramos, pecíolo, face inferior da folha, raque floral até o botão floral e o cálice. Estípulas lineares a oblongo agudas. Botão floral tomentoso-hirsuto com bractéolas lineares. No entanto, alguns espécimes, especialmente os arbustos e as arvoretas em dadas localidades, em orla de mata, na transição para o campo ou cerrado, como em Uberlândia e Araguari, em Minas Gerais, na reserva Ecológica do IBGE, em Brasília; e em Cuiabá, em Mato Grosso apresentam características intermediarias, entre as duas espécies, tanto ao nível de indumento da inflorescência, forma do botão floral, tanto quanto aos caracteres foliares de modo que, as duas espécies se sobrepõem e talvez, dependendo de novas informações sobre as populações, possa ser verificada a possibilidade de os espécimes representarem formas de vida diferentes, de subarbusto a arvoreta, de uma mesma entidade específica e, portanto, tratar ambas as espécies, junto com B. holophylla, como variedades de um mesmo táxon.

31. Bauhinia smilacifolia Burchell ex Bentham in Martius, Fl. Bras. 15(2):183.1870. - Tipo. Brasil. Goiás: entre Cavalcante e Conceiçäo, s/data (fl), Burchell 8076 (lectotipo $\mathrm{K}$, designado por Wunderlin, 1972 in sched.; fotografia RB! ex NY negativo 1579); prope Arrayas, abr 1840 (fr), Gardner 3698 (isossintipos BM!, E!, MANCH!, OXF!, fotografias RB! ex F negativo 1612, ex Kew negativo 16425).

Subarbusto. Entrenó distal 2-5 cm comprimento. Folhas inteiras, lâmina 6,2$12 \times 2,3-3,5 \mathrm{~cm}$, coriácea, ovado-lanceolada a lancolada, base cordado-auriculada, ápice obtuso, 5-7-nérvea, nervura marginal elevadoproeminente; face superior glabra, nervuras secundárias não impressas, face inferior glabra, tricomas glandulares ausentes, nervuras primárias proeminentes, secundárias pouco proeminentes a imersas, terciárias imersas; pecíolo 1,5-2,2 cm compr., delgado, glabro. Estípulas não vistas - ovóides extraflorais cônico-ovóides, submilimétricos. Inflorescência com comprimento desconhecido, curtopedunculada; pedúnculo $1,5 \mathrm{~cm}$ compr.; eixo racemiforme, delgado, glabro; inflorescências parciais 2-(3)-floras, folhas alternifloras presentes, lâmina $4 \times 2,2 \mathrm{~cm}$ até ausentes, brácteas foliáceas não vistas, nectários extraflorais submilimétricos. Botões $11 \times 0,4 \mathrm{~cm}$ na antese, lineares, ápice subcuspidado, nervação 5-imersa, glabros, sem tricomas glandulares. Flores, pedicelo $2 \mathrm{~cm}$ compr., bractéolas escamiformes, hipanto cilíndrico, $1,5 \mathrm{x} 0,4-0,5 \mathrm{~cm}$ compr., internamente tomentoso na região distal; cálice fendido na antese em 23 lobos, eretos, retorcidos ou não, 5,5-6,5 cm 
compr.; pétalas lineares, ca.1,5 cm compr., glabras; estaminódios 0 , estames 10, anteras iguais, lineares, não loceladas, filetes até $5 \mathrm{~cm}$ compr., filetes externamente glabros, coluna estaminal presente, $5 \mathrm{~mm}$ altura máxima, apêndice ligular ausente, internamente tomentosa, externamente glabra; gineceu completo não visto, estigma clavado, um dos lados aplanado-escorrente, ovário glabro, bordos com tricomas glandulares, estipe ca.3,5 cm compr., glabro. Legume deiscente, valvas $14-15 \times 1,5-1,7 \mathrm{~cm}$, glabro, estipe $3 \mathrm{~cm}$ cmpr.; lobos funiculares curto-triangulares. Sementes maduras não vistas.

Ocorre apenas no Brasil, nos estados de Goiás e Tocantins (Fig. 26). As localidades de ocorrência pertencem às Folhas IBGE (1960): SD-23: 47-13b, e 48-14c. Espécie campestre.

Frutificação em abril.

As coleções disponíveis indicam uma área de endemismo restrito a uma única população.

Categoria IUCN (1994): Deve ser verificada em campo a possibilidade Bauhinia smilacifolia estar extinta, pois não foi mais encontrada nas coleções a partir de 1840, cuja população se encontra em área sob forte impacto ambiental.

32. Bauhinia subclavata Bentham in Martius, Fl. Bras. 15 (2):188. 1870.- Tipo. Brasil. Piauí. entre o Rio Camindé e Oeiras, 1840 (bt/fr), s/ data, Gardner 2154 (holótipo não localizado; isótipos NY!, OXF!, P!, fotografias RB!, ex NY negativo 12714, ex F negativo e 1623).

Arbusto. Entrenó distal 1,5-3 cm comprimento. Folhas bilobadas, lâmina (4,5-) 8-11,5(-13)x(4,5-)6,5-9,5(-12) cm, tenuemente cartácea a subcoriácea, base cordada a emarginada ou subtruncada, 9-11-nérvea, nervura marginal inconspícua, lobos concrescidos em 2/3-3/4 ou mais do comprimento total, elíticos a ovado-oblongos, paralelos, ápice arredondado a obtusiúsculo; face superior vilosa, glabrescente, nervuras terciárias e quaternárias pouco impressas dando à superfície um aspecto ruguloso, face inferior pubescente até vilosula, especialmente na região das nervuras primárias, tricomas glandulares presentes abundantes, nervuras primárias proeminentes, secundárias e terciárias pouco proeminentes (proeminentes em Pernambuco, cf. cols Andrade-Lima 56-2588, 56-2599, 716406, 76-8310, 79-9657, Correia 436, Pereira 368); pecíolo 1-3 cm compr., delgado, tomentelo. Estípulas não vistas (diminutas ou rudimentares, segundo Bentham, 1870); nectários extraflorais rudimentares, não emergentes, até $1 \mathrm{~mm}$ comprimento. Inflorescência até $25 \mathrm{~cm}$ compr, curto-pedunculada; pedúnculo $0,5-2 \mathrm{~cm}$ compr.; eixo racemiforme, delgado, tomentelo; inflorescências parciais 2-floras; folhas alternifloras/opositifolias, ocasionalmente presentes, às vezes apenas emarginadas, ca. $2,5 \times 2,1 \mathrm{~cm}$, até reduzidas a brácteas foliáceas duplamente ovadas, ladeando mucron remanescente, $2 \times 1 \mathrm{~mm}$. Botões $5 \times 0,7-1,3 \mathrm{~cm}$ na antese, clavados, ápice alado-reentrante, 5estreitamente alados, alas onduladas em maior ou menor grau, tomentelos, com tricomas glandulares. Flores com pedicelo $0,5 \mathrm{~cm}$ compr., bractéolas ovadas, hipanto cilíndrico, 1,31,5x0,7-0,8 cm, internamente glabro; cálice fendido na antese em 5 lobos reflexos, $3-4 \mathrm{~cm}$ compr.; pétalas no botão préantese linearlanceoladas, obtusiúsculas, 2,7-3x0,2-0,4 cm, externamente cobertas por tricomas glandulares; estaminódios 0, estames 10, anteras iguais, lineares, não loceladas, filetes $2,4-3,2 \mathrm{~cm}$ compr., filetes alternipétalos esparsamente hirsutos em direção à base; coluna estaminal rudimentar, até ca. $2 \mathrm{~mm}$ altura máxima no botão pré-antese, apêndice obsoleto, interna e externamente hirsuta; gineceu compr. desconhecido, estigma subtransverso-capitado, ovário tomentelo, estipe ca.1,5 cm compr., glabrescente. Legume deiscente, valvas 8,5$23 \times 1,1-1,3 \mathrm{~cm}$, viloso-glandulosas, estipe 2,5$3,5 \mathrm{~cm}$ compr.; lobos funiculares uncinadolobados. Sementes ca.7-9x4-6 mm.

Ocorre no Brasil, estados Bahia, Ceará, Maranhão e Paraíba, Pernambuco, Piauí e Rio Grande do Norte (Fig. 26). As localidades registradas pertencem às Folhas IBGE (1960): Folha SA-23, SB-23, SB-24, SB-25, SC-23, SC- 
24 e SD-23 (Bahia). Habita em caatinga, cerrado, transição caatinga-cerrado, carrasco (vários coletores), floresta serrana, denominada "brejo de altitude", $1.082 \mathrm{~m}$ alt (M. Correia 436) e outras encostas das serras de Pernambuco (Andrade-Lima 56-2588, 56-2599, 71-6406, 768310, 79-9657, Correia 436, Pereira 368). No chapadão oriental da Bahia, habitat em floresta decídua (Harley 21707). Na região de Ilha de Balsas, no Maranhão (Eiten 10489, Eiten 4133 e, outros) habita no cume de "plateau" baixo com vegetação lenhosa de chapada, denominada localmente de cerradão e no carrasco. No Ceará, habita nas chapadas do Araripe (Fernandes e Matos s/n, EAC 13093) e planalto da Ibiapaba.

Espécimes com botão e botão/flor de fevereiro a abril, com frutos a partir de abril a setembro/outubro.

$\mathrm{Na}$ diagnose original (Bentham, 1870) os filetes são descritos como glabros ou com base pouquíssimo barbada. Os espécimes examinados, procedentes de áreas na mesma folha geográfica de Oeiras (SB-23), no Piauí, apresentavam filetes desde hirsutos no botão floral até hirsutos externamente e internamente. Os espécimes coletados nas serras de Pernambuco (cols Andrade-Lima 56-2588, 562599, 71-6406, 76-8310, 79-9657, Correia 436, Pereira 368), tinham folhas subcoriáceas e nervação da face inferior mais proeminentes e indumento vilósulo.

Bauhinia subclavata faz parte do complexo de espécies integrado por $B$. cheilantha e B. acuruana (tabela 1).

33. Bauhinia tenella Bentham in Martius, $\mathrm{Fl}$. Bras. 15(2): 195. 1870. - Tipos. Brasil. Tocantins: Arraias, em campos secos, março 1840 (bt/fl/fr), Gardner 3701 (K, designado por Wunderlin, 1991, in sched.; isolectotipos E!, MANCH!, OXF!, P!, W!, F negativo 1621!, fotografias RB!).

Arbusto ou subarbusto. Entrenó distal $1 \mathrm{~cm}$ comprimento. Folhas bifolioladas, cada folíolo $0,8-1,5(2,0) \times 0,4-1 \mathrm{~cm}$, cartáceo a coriáceo, incurvo-oblongo, livre ou quase livre, ápice obtuso, 2-3-nérveo, nervura marginal aplanada; face superior glabra, nervuras secundárias não impressas, face inferior tomentela, tricomas glandulares abundantes, nervuras primárias, secundárias e terciárias pouco proeminentes a imersas; pecíolo $0,2-0,5$ cm compr., delgado, tomentelo, tricomas glandulares abundantes. Estípulas rudimentares. Nectários extra-florais rudimentares, menores que $0,5 \mathrm{~mm}$ de compr. Inflorescência, até 16 cm compr., curto-pedunculada; pedúnculo 0,2$0,5 \mathrm{~cm}$ compr.; eixo racemiforme, delgado, tomentelo, inflorescências parciais 2-floras; folhas alternifloras, cada folíolo $0,3-1 \times 0,2-0,4$ $\mathrm{cm}$, progressivamente reduzidas em direção ao ápice, brácteas foliáceas rudimentares a ausentes. Botões 3,5x0,2-0,3 cm na antese, clavados, ápice apiculado-emarginado, tenuemente costados, tenuemente tomentelos, viscídulos, com tricomas glandulares. Flores, pedicelo 0,5-0,8 cm compr.; bractéolas escamiformes submilimétricas; hipanto cilíndrico, 0,5x0,3-0,4 cm, internamente irregularmente tomentoso na região distal; cálice fendido na antese em 3 lobos, reflexos, levemente ondulados, não retorcidos, calíce 2,5 cm compr.; pétalas lineares, ápice acuminado, 1,8-2,1x0,1 cm, externamente glabras; estaminódios 0 , estames 10, anteras iguais, lineares, não loceladas, filetes 1,8-2,5 cm compr., glabros; coluna estaminal com $3 \mathrm{~mm}$ altura máxima, apêndice ligular ausente, internamente tomentosa, externamente glabra; gineceu compr. desconhecido, estigma claviforme, ovário tomentelo, estipe $1,2 \mathrm{~cm}$ compr., com tricomas glandulares. Legume deiscente, valvas 9,5-10x 0,8 cm, glabro, estipe 2,5-3,5 cm cmpr.; lobos funiculares curto-emarginados. Sementes não vistas.

Ocorre no Brasil, estados de Goiás, Maranhão e Tocantins (Fig. 26). As localidades registradas pertencem às Folhas IBGE (1960): SB-23 e SD-23. Habita em carrasco e cerrado, campo cerrado, cerrado rodeado de campo úmido, cerrado junto a rochas, campo sujo. Em altitudes de 700 a $1.000 \mathrm{~m}$. Ocorre como subarbusto delgado 0,8 
a $2 \mathrm{~m}$ altura, formando moitas delicadas.

Botões e flores de janeiro a abril.

Bauhinia tenella pertence ao complexo B. fusconervis/B. pulchella (tabela 1).

34. Bauhinia ungulata Linnaeus, Sp. Pl. ed. 1, 374. 1753. Cansenia ungulata (Linnaeus) Rafinesque, Sylva Tell. 122.1838, sphalm. $C$. angulata [Veja comentário em Wunderlin, 1976, Rhodora 78(816): 753]. - Pauletia ungulata (L.) Schmitz, Bull. Jard. Bot. Natl. Belgique 43:393.1973. - Tipo. "Habitat in America." Herb. Clifford: 157, Bauhinia n 3 (lectótipo BM, designado por Wunderlin in Turland \& Jarvis, 1997).

Bauhinia macrostachya Bentham, Hook Journ. Bot. 2:96.1840. - Bauhinia benthamiana Taubert, in Engler \& Prantl ed. Natur. Planzenfam. 3.3 (71):149.1892.- Tipo. Guiana. Essequibo: 1836 (bt/fl/fr). Schomburgk 71 (holótipo K!, NY negativo 1593, fotografia RB!). Sin nov.

Bauhinia macrostachya var. tenuifolia Ducke, Arch. Jard. Bot. Rio de Janeiro 3:106. 1922. Tipo. Brasil. Pará: Belém, julho 1901 (bt), Huber s/n (RB 11132!, lectotipo aqui designado, MG 2103, isolectotipo). Sin nov.

Arbusto ou arvoreta ou subarbusto. Entrenó distal 0,5-3 cm comprimento. Folhas bilobadas, lâmina (1,1-)2,6-13(-18)x(1,2-)3-8($9,5-12,5) \mathrm{cm}$, tênue cartácea a subcoriácea, base subtruncada a cordada, 7-9-sub 11-nérvea, nervura marginal inconpícua, lobos concrescidos em $1 / 2$ a $2 / 3$, raramente menos de $1 / 3$ ou mais de $2 / 3$ do comprimento total, ovado-oblongos a oblongo-triangulares, retos e no ápice paralelos ou um pouco convergentes ou ainda um pouco divergentes, até elíticos ou suborbicu-lados, ápice longamente acuminado ou agudo a obtuso ou arredondado; face superior glabra, não impressas, face inferior cano- ou ferrugíneo- ou fusco-pubescente a tomentela em toda a superfície, em maior ou menor grau a ferrugíneo-pubescente, especialmente nas nervuras, tricomas glandulares presentes, abundantes ou não, nervuras primárias mais ou menos proeminentes, secundárias pouco proeminentes a imersas e terciárias imersas; pecíolo 0,9-3 cm compr., delgado, cano- ou ferrugíneo ou fuscotomentelo. Estípulas ovado-lanceoladas a oblanceoladas ou falcado-oblongas, 3-25×2-8 $\mathrm{mm}$, quebradiças até rudimentares, sub-milimétricas; nectários extraflorais rudimentares, raramente ovóides (Rio Aripuanã), $1 \mathrm{~mm}$ comprimento, em geral totalmente encobertos pelas estípulas até rudimentares, submilimétricos. Inflorescência até $37 \mathrm{~cm}$ compr., curto-pedunculada; pedúnculo $0,2-3 \mathrm{~cm}$ compr.; eixo racemiforme, delgado, cano- ou ferrugíneo- ou fusco-tomentela, às vezes 1-2 ou mais eixos simultâneos; inflorescências parciais 2-floras; folhas opositifloras/ alternifloras ausentes, brácteas foliáceas falcado-oblongas a rudimentares, submilimétricas, mucron às vezes presentes. Botões 4,5-5x0,4 cm na antese, subclavados, ápice obtuso a reentrante-espessado, fusco- ou ferrugíneo- ou fulvo-tomentelos e lisos ou canoestriados e, então, desde obscuramente 5estriado até multiestriados, com tricomas glandulares. Flores, pedicelo (0,3-0,4-)0,5-1,1 cm compr., bractéolas oblongo-lanceoladas a ovadas, hipanto cilíndrico a suburceolado, 0,5 $1,5 \times(0,3-) 0,4-0,7 \mathrm{~cm}$, internamente glabro; cálice fendido na antese em 3-5 lobos reflexos, ondulados a retorcidos, 1,7-3,5 cm compr.; pétalas linear-lanceolada, caudada, ca.1,6$3 \times 0,1-0,2 \mathrm{~cm}$, externamente glabras; estaminódios 0 , estames 10 , anteras iguais, lineares, não loce-ladas, filetes (1,3-1,7-) 2,5-3 $\mathrm{cm}$ compr., filetes alternipétalos pilosos externamente; coluna estaminal rudimentar, até ca.1 mm altura máxima, apêndices rudimentares, internamente com tufos de tricomas, extermente pilosa; gineceu (2-4,2-)4,5 cm compr., estigma oblíquo-clavado, ovário tomentoso, estipe 1,5-2 cm compr., tomentoso a quase glabro. Legume deiscente, valvas 11,520x0,9-1,2 cm, tomentelas a glabrescentes, estipe 2-3 cm compr.; lobos funiculares uncinado-lobados. Sementes 5-7x5-6 mm.

$\mathrm{O}$ conceito de $B$. ungulata é ampliado neste trabalho abrangendo populações deste 
o México tendo como limite sul as folhas SF21 , latitude $23^{\circ} \mathrm{S}$, município de Amambaí no Mato Grosso do Sul e SF-23, latitude $21^{\circ} / 22^{\circ} \mathrm{S}$, municípios de Barra do Piraí (Rio de Janeiro)/ São Sebastião do Paraíso (Minas)/ São Carlos (São Paulo), se constituindo na espécie cujos caracteres compartilhados por todos os indivíduos são o tipo de coluna estaminal rudimentar, com apêndice interno barbado, pétala superior mais larga, ca. de $2 \mathrm{~mm}$ de largura. Trata-se da espécie mais amplamente distribuída em Bauhinia ser. Cansenia, e altamente variável, mas com certos padrões locais, os quais foram reconhecidos artificialmente, na categoria variedade, admitindo-se formas intermediárias entre elas.

34a. Bauhinia ungulata var. cuiabensis (Bongard) Vaz, comb. nov. - Pauletia cuyabensis Bongard, Mem. Acad. Imp. Sci. St. Petersb., ser. 4 sci. Math. 2: 125. 1836. Bauhinia cuiabensis (Bongard) Steudel Nom. ed. 2: 1. 191.-Bauhinia cuiabensis (Bongard) D. Dietrich, Syn. Pl. 2:1476. dezembro 1840. Bauhinia cuiabensis (Bongard) Walpers, Repert. Bot. Syst. 1: 848. 1842. - Tipo. Brasil. Mato Grosso: Cuiabá, fev. 1826(bt/fr), Riedel 829 (holótipo LE, fotografia BAB!, RB!).

Bauhinia angulicaulis Harms, Bot. Jahrb. 33(72): 20. 1903. - Bauhinia angularis Harms ex Glaziou. Bull. Soc. Bot. France 52. Mém 1(3): 172. 1906. (variante ortográfico para B. angulicaulis Harms). - Tipo. Brasil. Goiás, "Fazenda do Palmital", jun 1895 (bt), Glaziou 21018 (Holótipo não localizado; isótipos C!, K!, F negativo 1563, fotografias RB!). Sin. nov.
Bauhinia cujabensis f. ferruginea Chodat \& Hassler, Bull. L'Herb. Boiss 2eme ser. 4:689.1904. - Sintipos. Paraguai. "ad marginem silvae pr. Arroyo Mocoy, Sierra de Maracaju", nov., Hassler 5380 (isossintipos BM!, GRAH!, NY! negativo 12726, fotografia RB!); "in dumetis pr. Conception, aug., Hassler 7192 (isossintipos NY!, P!, NY negative 12727, fotografia RB!); idem 7192a (isossintipo NY!, NY negative 12728, P, fotografia RB!). Sin. nov.

Bauhinia cujabensis f. vestita Chodat \& Hassler, Bull. L'Herb. Boiss., 2eme ser. 4:689.1904. - Sintipos: Paraguai, “ in campo Apipu (Tapiraguay), dec., Hassler 5953 (isossíntipo BM!, GRAH!, NY!, NY negative 12725 , fotografia $R B$ !); ad marginem silvarum in vale fluminis Y-aca, dec., Hassler 6654 (isossíntipos BM!, NY!, NY negative 12724, fotografia RB!). Sin. nov.

Bauhinia hiemalis Malme, Ark. Bot. Stockh. 5(5):13.1905. - Tipo. Brasil. Mato Grosso. Cuiabá. jun 1902 (bt), Malme II: 1628 (lectótipo S!, designado por Vaz, 1995). Sin. nov.

Bauhinia chapadensis Malme, Arkiv. Bot. Stockh. 5(5): 13.1905.- Tipo. Brasil. Mato Grosso: "Santa Anna da Chapada (atual Chapada dos Guimarães), jun. 1903 (bt/fr), Malme II:3409a (lectótipo S!, designado por Vaz, 1995). Sin. nov.

Bauhinia cataholo Hoehne, Comm. Linh. Telegr. Matto Grosso Amaz. Annexo 5. Bot. (8):34, t.140.1919. - Tipo. Brasil. Mato Grosso. rio Juruena, maio 1909 (bt/fl), Hoehne Comm. Rondon nº 1989 (holótipo R!, fotografia RB!). Sin nov.

\section{CHAVE PARA AS VARIEDADES DE BAUHINIA UNGULATA OCORRENTES NO BRASIL - REGIÕES NORTE E NORDESTE}

1. Folhas (2,3-)7,3-13x(2-)6-8,4 cm, face inferior rufo-pubescente, pecíolo 0,9-2,5 cm comprimento, hipanto $0,5-1 \times 0,4-0,7 \mathrm{~cm}$ na flor aberta

1. Folhas 1,5-3,4x1-2,6 cm, face inferior cano-pubescente, pecíolo 0,5-1 cm compr., hipanto 0,5$0,8 \times 0,3 \mathrm{~cm}$ na flor aberta B.ungulata var. parvifolia

2. Ápice agudo ou longamente acuminado B. ungulata var. ungulata

2. Ápice obtuso B. ungulata var. obtusifolia 


\section{CHAVE PARA AS VARIEDADES DE BAUHINIA UNGULATA OCORRENTES NO BRASIL - REGIÕES CENTRO-OESTE E SUDESTE}

1. Folhas tenuemente cartáceas a cartáceas, ápice agudo a acuminado 2

1. Folhas firmemente cartáceas a coriáceas, de aguda a obtusa até arredondada, lâminas de maior tamanho (observar no material fértil) 4-7,5(-10,5)x4-6,5(-12,5) cm .... B. ungulata var. cuiabensis

2. Folhas de maior tamanho (observar no espécime fértil) entre 11-18x8,5-9,5 cm, brácteas e bractéolas falcado-oblongas a estreito-oblongas até $2,5 \times 1 \mathrm{~cm}$, caducas B. ungulata var. ungulata

2. Folhas de maior tamanho (observar no material fértil) $1,5-5 \times 1-3,2 \mathrm{~cm}$, brácteas e bractéolas rudimentares B. ungulata var. parvifolia

Ocorre no Paraguai e Brasil, nos estados de Bahia, Goiás, Mato Grosso, Mato Grosso do Sul, Minas Gerais, Rio de Janeiro, São Paulo, Tocantins e Distrtito Federal (Fig. 28). As localidades registradas pertencem às Folhas IBGE (1960): folhas SC-23, SD-21, SD-22, SD23, SE-21, SE-22, SE-22, SF-21, SF-22 e SF23. Habita em floresta de galeria, florestas abertas, florestas semidecíduas, zona de transição floresta-cerrados, cerrados perturbados ou sub-ruderais, em locais úmidos ou inundáveis, cerrado, cerradão, campo cerrado, campo sujo, campo úmido, campo periodicamente inundado e em formações do pantanal, por exemplo cordilheira, alagáveis ou não; cerrado com vale dominado por babaçu (col. Irwin 17479), carrasco e caatinga. No Rio de Janeiro é referida por apenas uma única coleta, em Ipiabas (col. Laclette 924).

Apresenta o hábito de subarbusto ca.0,5 $\mathrm{m}$, ou de arbusto pouco ramificado de 1-3 m, com ramos cinéreos com ramos subcilíndricos a quadrangulares, pubérulos a quase glabros ou, ainda, de arvoreta com $5 \mathrm{~m}$ de altura. Em Goiás, espécimes do rio Gameleira (col. J. M. Pires 16157), de Aragarças (col. Irwin 17479), ao sul de Caiapônia (col. Anderson 9488) e o tipo de $B$. angulicaulis, coletado na Fazenda do Palmital apresentam ramos alados. Este caráter não foi encontrado em nenhuma outra espécie da série Cansenia, e até agora os espécimes com ramos alados são restritos a uma área no norte de Goiás (folhas SD-22, SE-22), mas esta característica não se mostra constante em todos os espécimes da área e não se correlaciona de modo consistente a nenhum outro caráter da morfologia externa, de modo que seja possível atribuir o status de variedade à população em questão.

Espécimes coletados em Xavantina, município Barra do Garças podem apresentar brácteas oblongas como as encontradas na var. ungulata do norte do Mato Grosso (Eiten et Eiten 8314; Irwin et al. 17111, etc.). O espécime R. Neves s/n, RUSU, coletado em solo humoso, em Ribeirão Preto, apresenta inflorescência que difere dos outros exemplares examinados var. cuiabensis por apresentar estípulas oblongoelíticas, tardiamente caducas, $1,2-15 \times 0,4-0,5 \mathrm{~cm}$, além de brácteas e bractéolas elíticas a estreitolanceolada, semelhante aos da variedade ungulata.

O gradiente folhas agudas, mais longas que largas, de orla de floresta até folhas menores e obtusas, coriáceas, em cerrado e, cartáceas em campo úmido ou floresta inundável, tanto com indumento com indumento cinzento como ferrugíneo pode ser observado nas coleções de Mato Grosso, especialmente as de Malme e de Irwin et al. 17089 (em Xavantina). Nas imediações da estrada São Miguel do Araguaia - Luiz Alves (col. Vaz 388, e seguintes até 402) foi observado o gradiente, desde as formas de cerrado, folhas menores coriáceas até as de floresta, inclusive as formas de arbustinho frágil, das margens inundáveis do rio, consideradas como Bauhinia ungulata var. parvifolia. Floresce a partir de maio/junho/julho. 
Exemplares com frutos imaturos foram coletados a partir de agosto.

34b. Bauhinia ungulata var. obtusifolia (Ducke) Vaz, comb. nov. - Bauhinia macrostachya var. obtusifolia Ducke, Arch. Jard. Bot. Rio de Janeiro 3:106. 1922. - Tipo. Brasil. Pará: Alcobaça (atual Tucuruí, cf. Egler 1963:117), rio Tocantins, julho 1916 (bt/fl/fr), Ducke s/n (RB 11146!, lectótipo aqui designado; MG 16192, isolectotipo).

Ocorre apenas no Brasil, estados do Maranhão, Pará e Rondônia (Fig. 28).

As localidades registradas pertencem às Folhas IBGE (1960): SA-22, SA-23, SB-22, SB23, SC-20, SC-22. Habita em manchas de solo em afloramentos graníticos (D. Frame et al. 107) e Campinarana (M.G. Silva 6296); floresta de terra firme, muito freqüente na vegetação secundária e capoeiras, floresta aberta com cipós, margem de rios.

34c. Bauhinia ungulata var. parvifolia (Ducke) Vaz, comb. nov. - Bauhinia macrostachya var. parvifolia Ducke, Arch. Jard. Bot. Rio de Janeiro 3:106. 1922. - Tipo. Brasil. Pará: Itaboca, rio Tocantins, julho 1916 (bt/fl/fr), Ducke s/n (RB 11137!, lectótipo aqui designado, MG 16232).

Ocorre apenas no Brasil. Estados de Goiás Pará, Maranhão, Piauí e Tocantins (Fig. 28).

As localidades registradas pertencem às Folhas IBGE (1960): SB-22, SB-23, SC-22, SC-23 e SD-22.

Arbusto ou arvoreta delgada (segundo Ducke, 1922), arbusto esparramado. Habita em cerrado ou mata alterada da borda do Córrego (Bucci et Jesus 126) e margens inundáveis do rio Araguaia.

As variedades ungulata e parvifolia podem ocorrer na mesma área de coleta, por exemplo na Serra da Malícia, no Maranhão (Pires et Black 2323 e Pires et Black 2347, respectivamente), sendo ambas os táxons considerados, neste trabalho, como elementos da flora amazônica. 34d. Bauhinia ungulata Linnaeus var. ungulata. - Tipo e sinônimos sob $B$. ungulata

Figuras 18, 19

Ocorre em Belize, Costa Rica, Guatemala, Nicaragua e Panamá (Wunderlin, 1983). Ocorre também na Bolívia, Colômbia, Guiana, México Paraguai, Venezuela e Brasil (Fig. 28). Nos estados do Acre, Amapá, Amazonas, Ceará, Maranhão, Mato Grosso, Pará, Piauí, Rondônia e Roraima. As localidades registradas pertencem às Folhas IBGE (1960): NA-20, NA-22, SA-21, SA-22, SA-23, SA-24, SB-20, SB-22, SB-23, SB-24, SC-19; SC-20, SC-21 e SC-24. Habita em floresta de terra firme, vegetação secundária ao longo de estradas e margens de pastos, floresta semidecídua (A.P. Duarte 7217), afloramento de granito e floresta circundante, (W. Thomas 5209), margem de floresta com campo, margem de rios, floresta seca de savana, cerrado na encosta da Serra da Lua, campo alagado periodicamente. No nordeste, habita em área de carrasco, caatinga arbórea, em floresta, cerrado, cerradões e vegetação secundária.

Floresce a partir de maio/junho/julho. Exemplares frutíferos foram coletados a partir de agosto. As coleções de Roraima apresentam botões, flores e frutos imaturos simultâneos nos meses de agosto, janeiro e fevereiro.

$O$ conceito de $B$. ungulata var. ungulata, aqui adotado, corresponde ao de $B$. macrostachya Benth., na Flora Brasiliensis (1870), porém ampliado para abranger os espécimes do nordeste, considerados como testemunhos do elemento amazônico na flora nordestina, e do Mato Grosso, em região ainda com influência das formações florestais amazônicas.

Os espécimes (cols Prance 5881, 5915) coletados na rodovia Abunã - Rio Branco, no Acre, diferem da variedade típica por apresentar folhas longamente acuminadas; cálice verde com estrias vermelhas; pétalas brancas e filetes avermelhados quando envelhecem; folhas com face inferior com superfície glaucescente, dando um aspecto cinzento na exsicata ou não glaucescentes e 
Vaz, A.M.S. da F. e Tozzi, A.M.G.A.

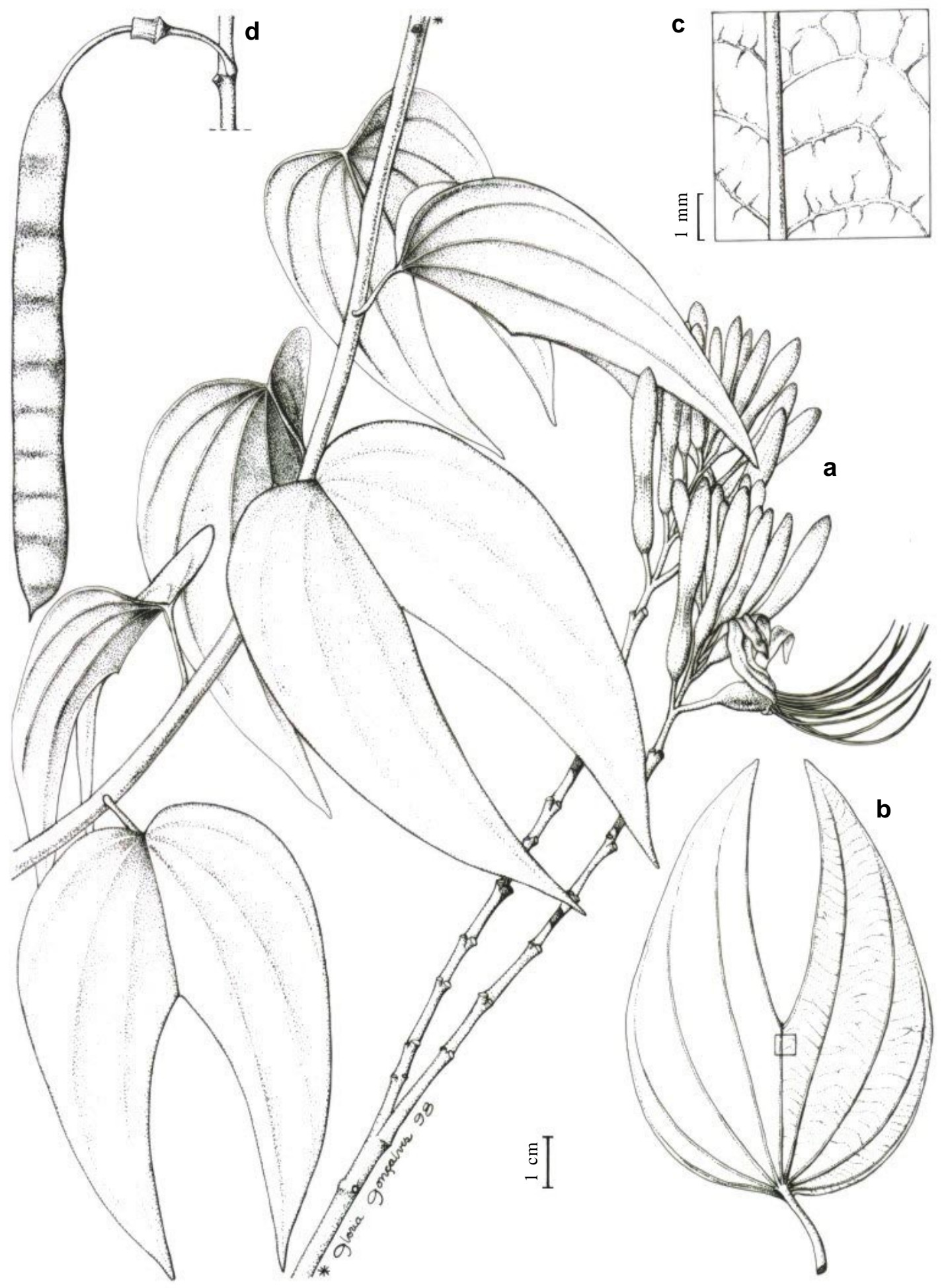

Figura 18 - Bauhinia ungulata var. ungulata (a-c, Giordano 1164; d, Conti s/n, RB 267728): a, ramo; b, contorno foliar; c, detalhe do indumento na face inferior da folha; d, fruto. Desenho G. Gonçalves 1998. 

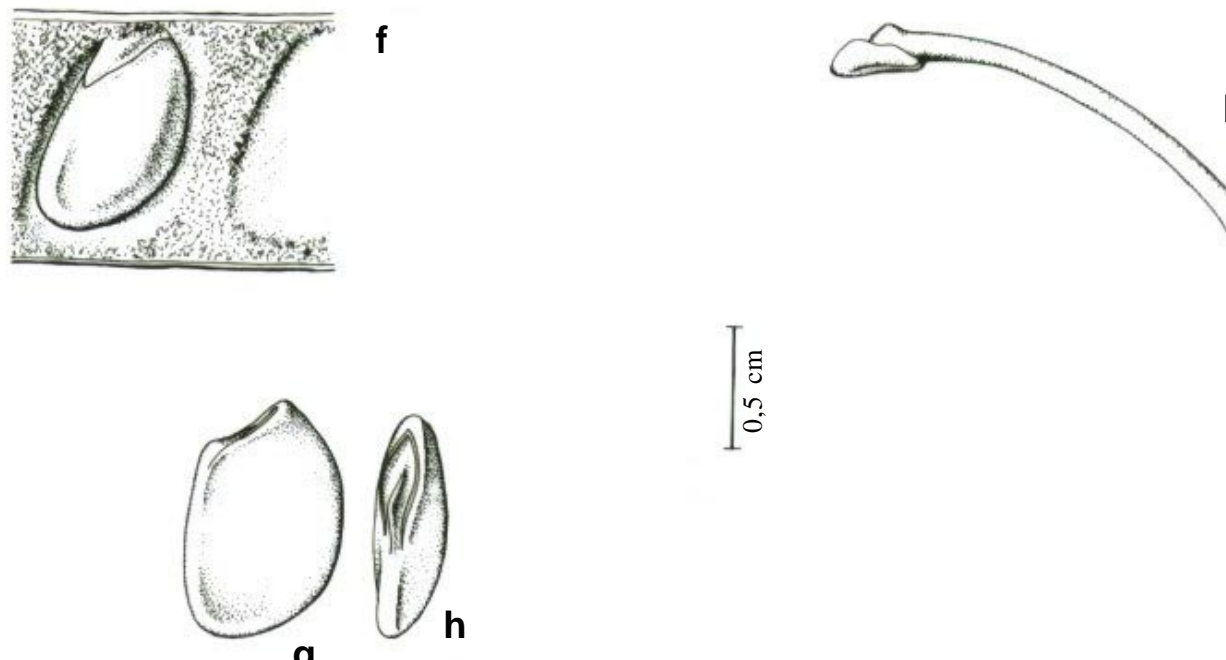

g

h
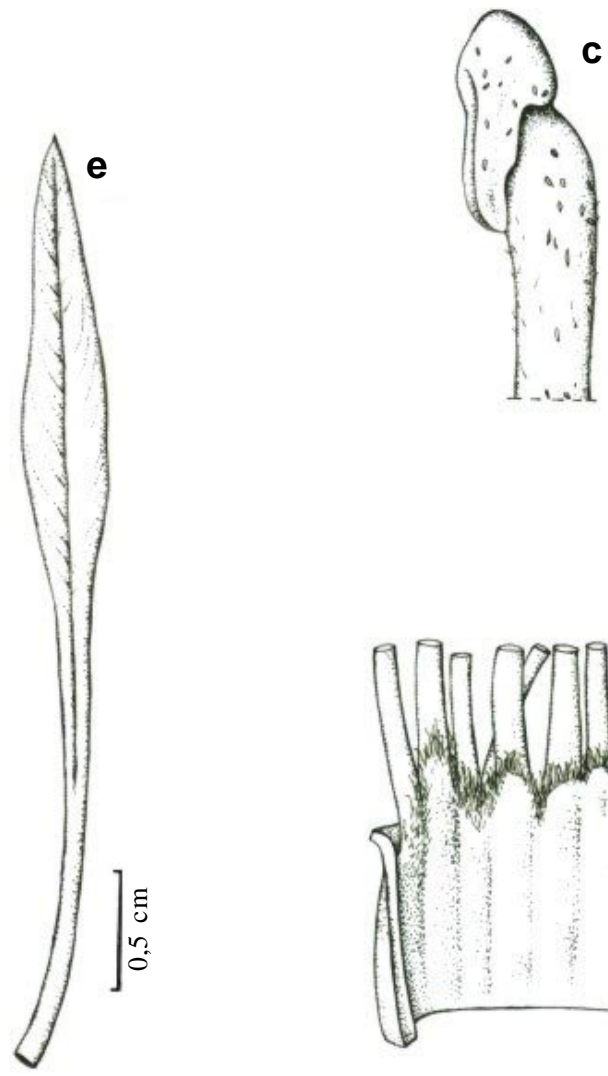

] 寻

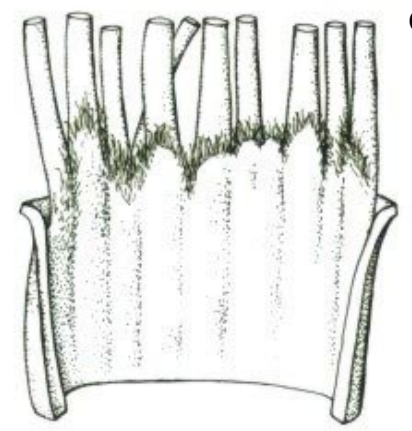

d

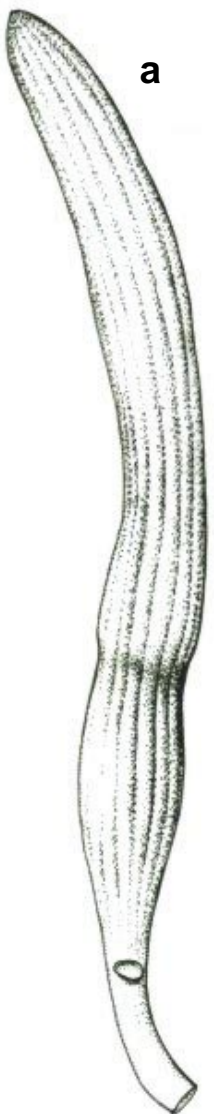

glowa gongativer 98

Figura 19 - Bauhinia ungulata var. ungulata (a-e, Vaz 1178; f-g, Conti s/n, RB 267728): a, botão; b, gineceu, onde se vê a inserção do ginóforo no hipanto; c, detalhe do estigma; d, coluna estaminal em continuidade com a face interna do hipanto; e, pétala na antese; f, detalhe da valva com semente; $g$, semente em vista lateral; $h$, semente vista de perfil. Desenho G. Gonçalves, 1998. 


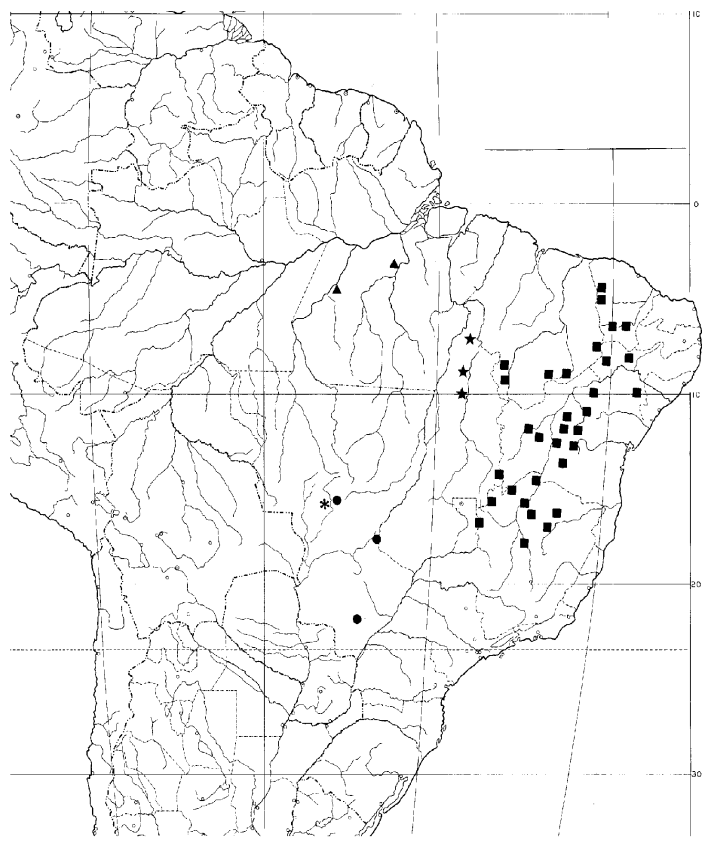

Figura 20 - Distribuição geográfica de B. acuruana (ロ), B. aureopunctata $(\boldsymbol{\Delta})$, B. burchelli $(\star)$, B. caloneura (*) e B. campestris $(\bullet)$ no Brasil.

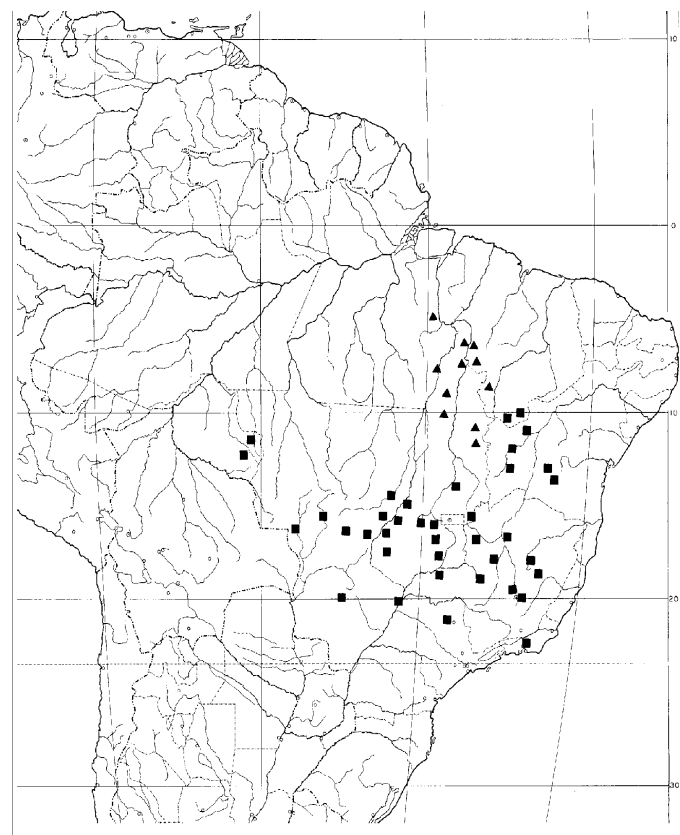

Figura 21 - Distribuição geográfica de B. brevipes $(\boldsymbol{\square})$ e B. bombaciflora $(\boldsymbol{\Delta})$ no Brasil. com indumento apresso avermelhado.

Os espécimes Gardner 1567, 2531, procedentes do Ceará e Piauí, citados por Bentham, na Flora Brasiliensis (1870: 191) como B. cuiabensis foram identificados aqui, como B. ungulata variedade típica.

35. Bauhinia urocalyx Harms, Notizbl. Bot. Gart. Berlin-Dahlem 6(59):308.1915. - Tipo: Brasil. Acre (?). Rio Branco. "Jurua-Miry, Lago", jun 1901 (bt/fr imat.), Ule 5542 (holótipo $\mathrm{B}$, perdido, F negativo 1625, fotografia RB!).

Arbusto. Folhas bilobadas, lâmina 1014x9-14 cm, cartácea a subcoriácea, base arredondada ou subtruncada até levemente cordada, 7-9-nérvea, nervura marginal infranerviforme; lobos concrescidos em menos de 1/3 do comprimento total, ovado-oblongos, pouco divergentes, ápice curtamente acuminado a obtusiusculo; face superior glabra, face inferior pubérula (= tricomas curtos e apressos), nervuras secundárias impressas, nervuras

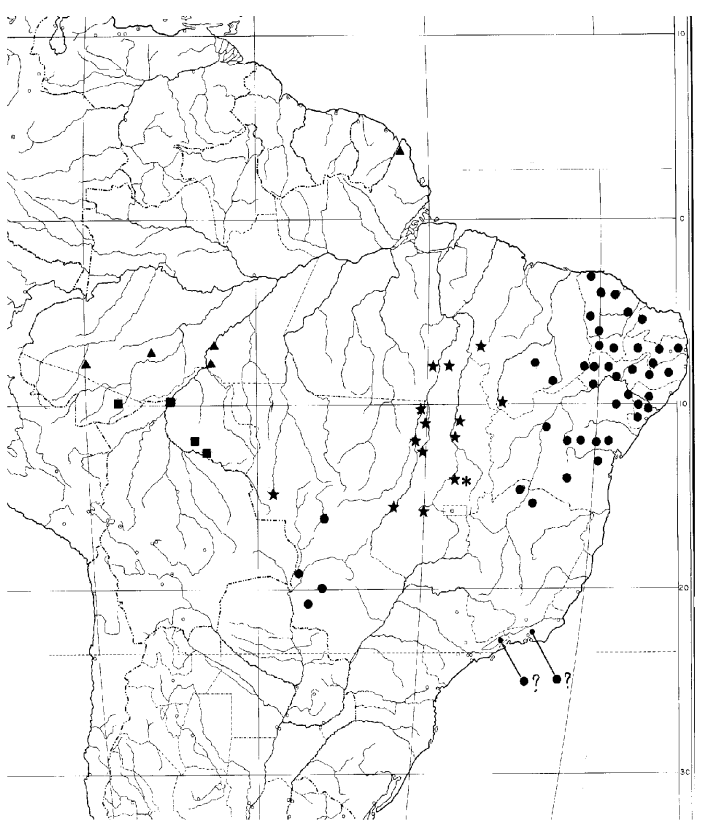

Figura 22 - Distribuição geográfica de $B$. candelabriformis $(*), B$. cheilantha $(\bullet), B$. cinnamomea $(\boldsymbol{\Delta})$, B. conwayi $(\boldsymbol{\square})$ e B. cupulata $(\star)$ no Brasil.

Rodriguésia 54 (83): 55-143. 2003 


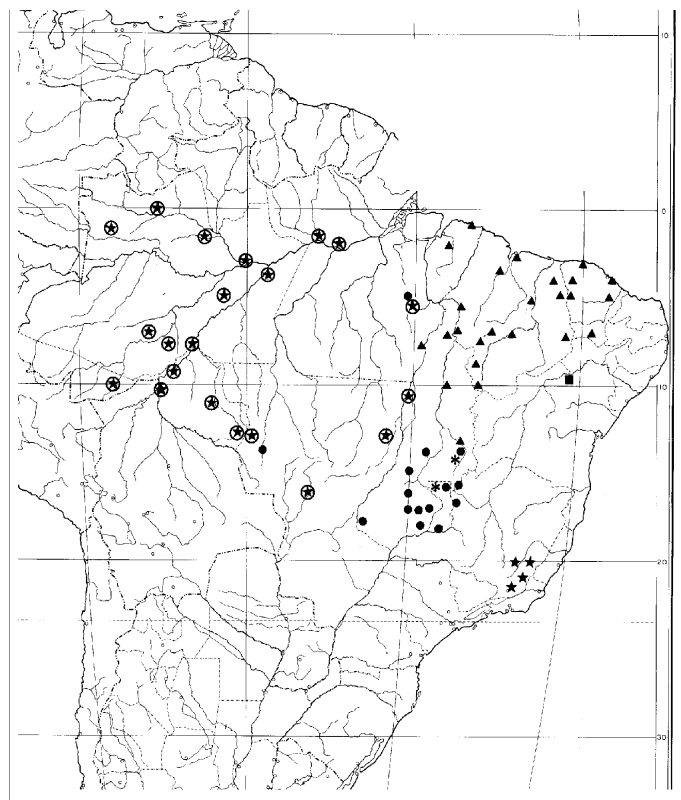

Figura 23 - Distribuição geográfica de B. curvula $(\bullet)$, B. dubia (४), B. dumosa var. dumosa (অ), B. dumosa var. viscidula (*), B. fusconervis ( $\star$ ) e B. longicuspis (४) no Brasil.

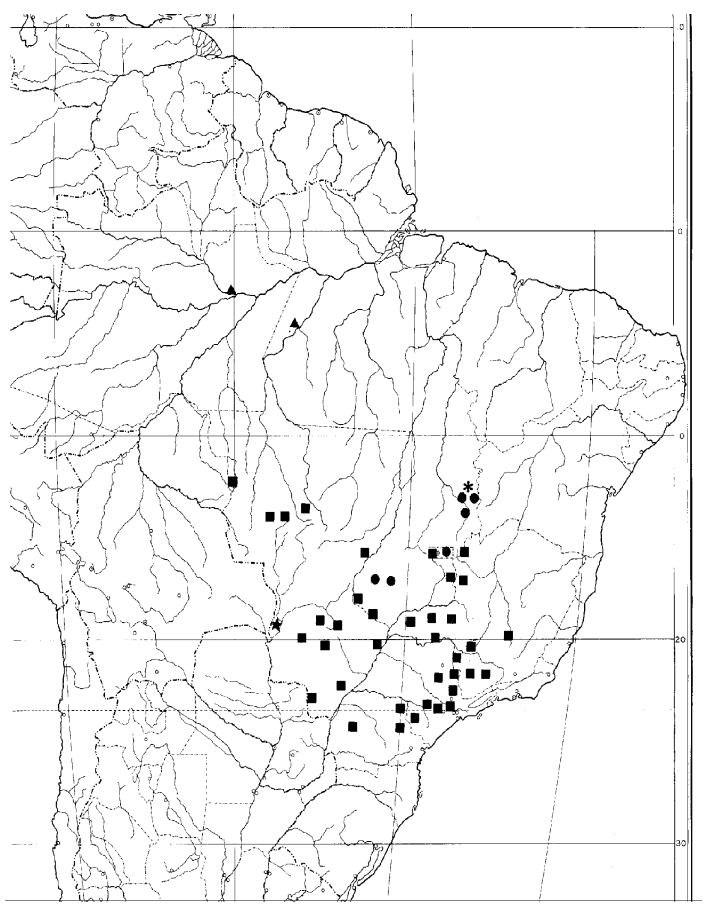

Figura 24 - Distribuição geográfica de B. gardneri (*), B. goyazensis $(\bullet)$, B. grandifolia $(\boldsymbol{\bullet})$, B. holophylla $(\mathbf{\square})$ e B. leptantha ( $\star$ ) no Brasil. primárias proeminentes, secundárias pouco proeminentes; pecíolo 1,5-3,5 cm compr., delgado, pubérulo a glabro. Inflorescência até 15-30 cm compr. ou maior; curto-pedunculada, eixo racemiforme; eixo delgado, apressosubvelutino-pubescente; inflorescências parciais 2-floras. Botões na antese, clavadocaudados, ápice mais ou menos prolongado em acumen tênue, indumento brevíssimo apressos subvelutinos, cor marron escura. Flores, cálice fendido na antese em 3-5 lobos reflexos, retorcidos, ca.7,0 cm compr.; pétalas lineareslongamente-unguiculadas; anteras iguais, lineares, filetes hirsuto-vilósulo na base; coluna estaminal; ovário velutino. Legume deiscente, valvas $21 \times 1,8 \mathrm{~cm}$, estipe $3 \mathrm{~cm}$ compr.

Ocorre no Peru (Macbride, 1943), Bolívia (col. R. Guillen \& V.C. Chire 3668, CTES) e Brasil. Macbride (1943) descreveu B. urocalyx na Flora do Peru, porém, com base apenas em

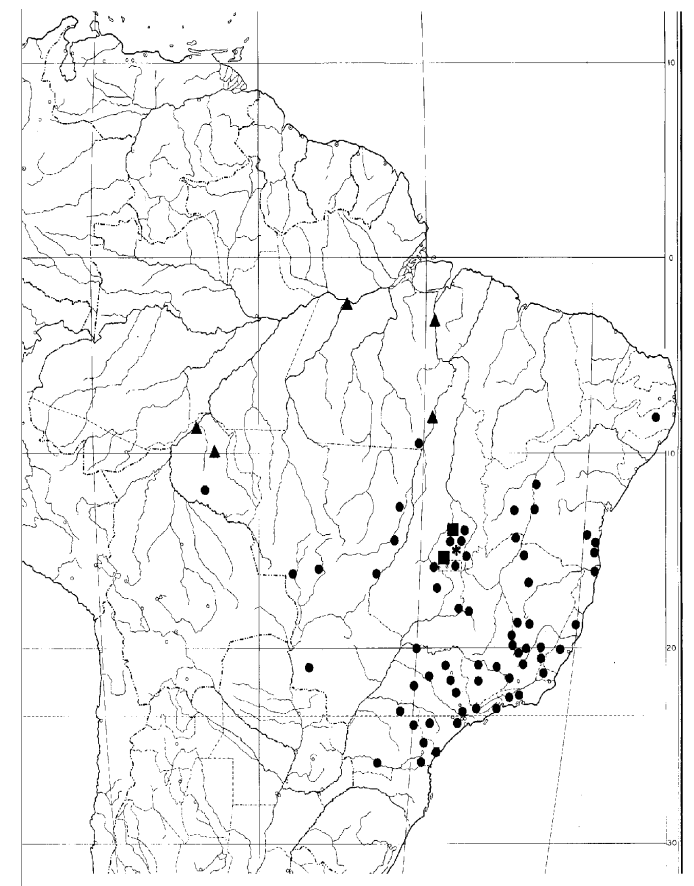

Figura 25 - Distribuição geográfica de B. longifolia $(\bullet)$, $B$. longipedicellata $(\boldsymbol{\Delta}), B$. malacotricha $(\boldsymbol{\square})$ e $B$. malacotrichoides (*) no Brasil. 


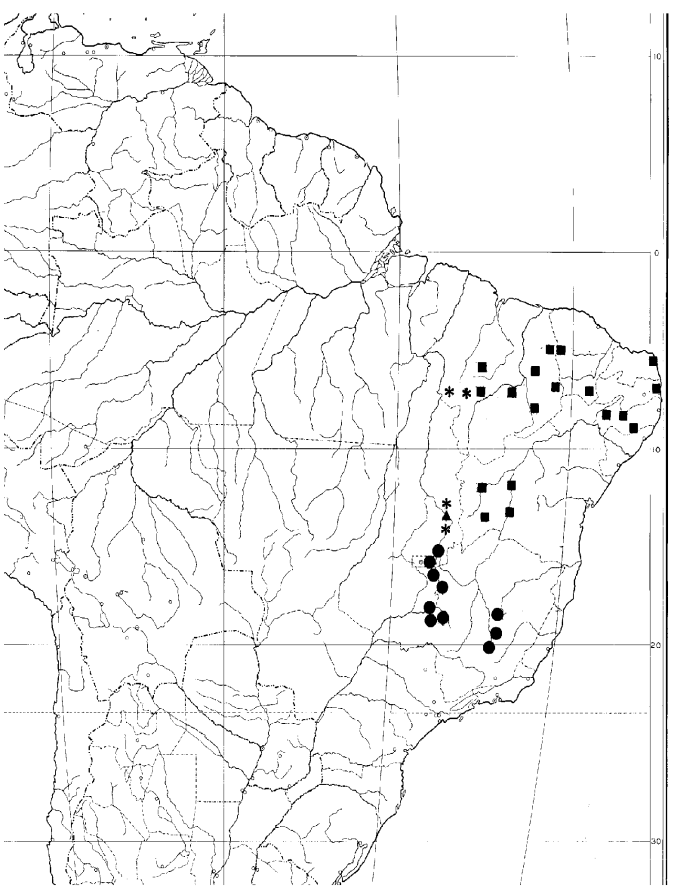

Figura 26 - Distribuição geográfica de $B . r u f a(\bullet), B$. smilacifolia $(\boldsymbol{\Delta})$, B. subclavata $(\square)$ e B. tenella (*) no Brasil.

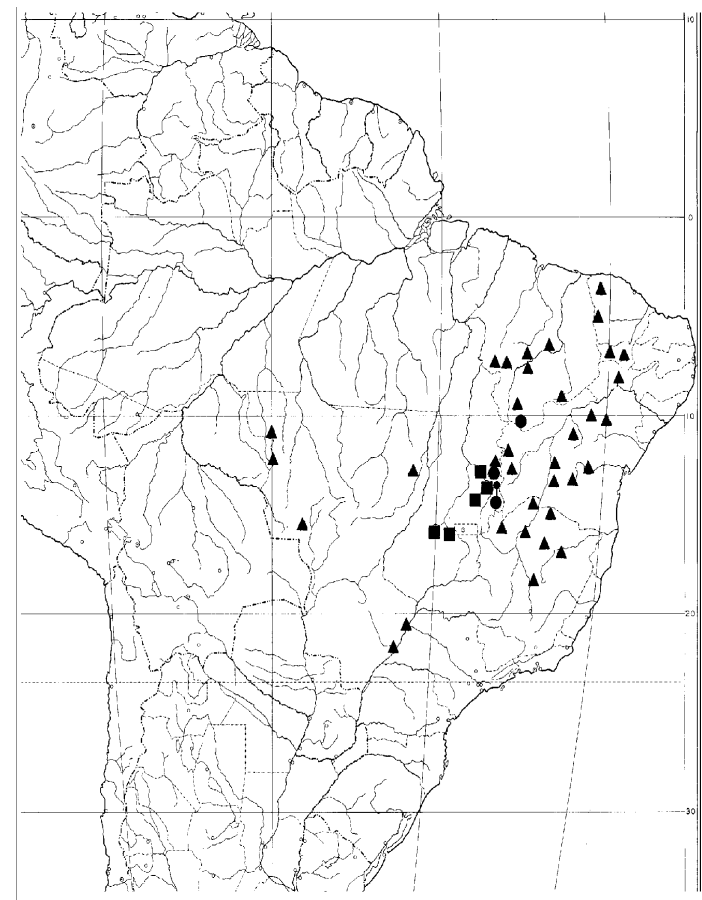

Figura 27 - Distribuição geográfica de B. membranacea $(\bullet)$, B. pulchella $(\boldsymbol{\Delta})$ e B. platyphylla $(\mathbf{\square})$ no Brasil. material estéril do Rio Itaya e Yurimagas. No Brasil, ocorreria no Acre, (Fig. 28). Folha SC$18,73-8 \mathrm{c}$.

Nenhuma coleção foi examinada, além da fotografia do holótipo. Na descrição acima transcrevemos, apenas, os dados da descrição original. Bauhinia urocalyx pertence ao complexo B. cinnamomea - B. grandifolia (Bong.) Steud. com o qual compartilha o mesmo tipo de nervação foliar, pétalas longamente unguiculadas e contorno do botão floral tutuloso-acuminado.

\section{HOMENAGEM}

À memória da Prof. Dra. Graziela Maciel Barroso pelo exemplo de dedicação ao estudo da Sistemática de Angiospermas no Brasil.

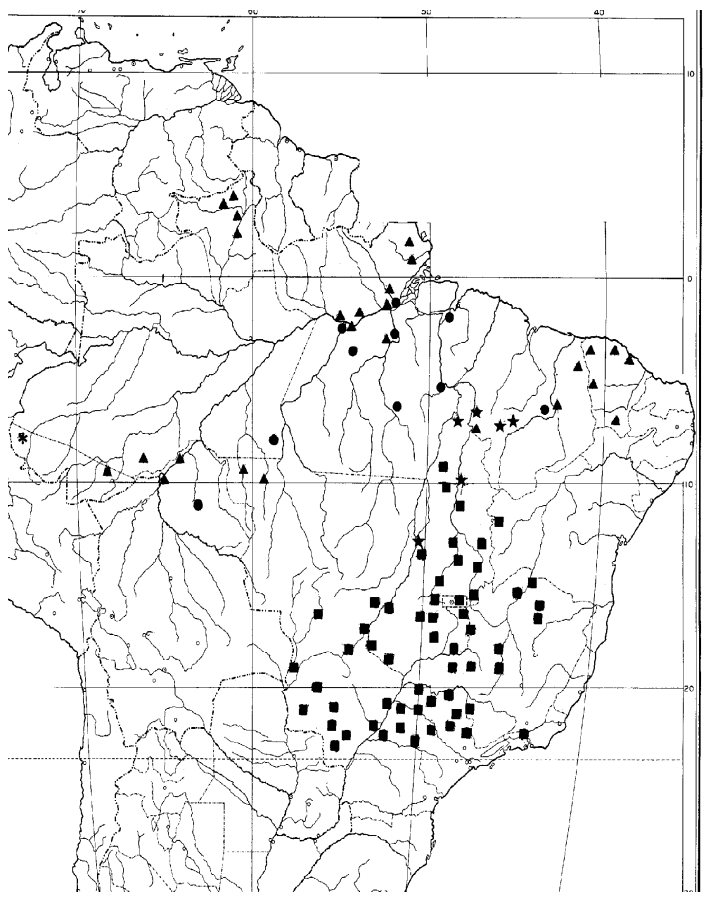

Figura 28. Distribuição geográfica de $B$. ungulata var. cuyabensis (অ), B. ungulata var. obtusifolia $(\bullet), \boldsymbol{B}$. ungulata var. parvifolia $(\star), B$. ungulata var. ungulata $(\Delta)$, e $B$. urocalyx (*) no Brasil.

Rodriguésia 54 (83): 55-143. 2003 


\section{AGRADECIMENTOS}

Ao CNPq, pela bolsa de doutorado concedida a Angela Vaz (processo 141739/ 1995-9). Aos curadores dos herbários citados pelo empréstimo de coleções, pelo envio de duplicatas e de fotografias de tipos ao herbário RB. À Prof. Msc. Maria Helena Rezende pela cessão dos negativos de nectários extraflorais de Bauhinia curvula. Ao colega Prof. Ronaldo Marquete (IBGE/DERNA/DIREN) pelo auxílio na plotagem dos pontos de coleta nos mapas apresentados. Às ilustradoras Aline de Souza Oliveira e Glória Gonçalves pelo empenho na resolução da representação dos caracteres nas pranchas confeccionadas. À Dra Angela Borges Martins (UNICAMP), ao Dr. Tarcísio Figueiras (IBGE), e ao Dr. Haroldo Cavalcante de Lima pelas sugestões e correções no manuscrito. Ao revisor anônimo pela cuidadosa revisão e importantes observações.

\section{REFERÊNCIAS BIBLIOGRÁFICAS}

Barroso, G.M.; Morim, P. M.; Peixoto, A.L.; Ichaso, C.L.F. 1999. Frutos e sementes:

Bergallo, H. de G. 1990. Biologia floral e polinização de Bauhinia bongardii Steud. na Serra dos Carajás, Pará. Revista Brasileira de Biologia 50 (2): 401-405.

Bongard, H.G. 1836 (1838). Bauhinieae et Pauletiae species brasiliensis novae. Mémoires de l'académie impériale des sciences de St.-Pétersbourg. Sixième série. Sciences mathématiques, physiques et naturelles. Seconde partie : Sciences naturelles 4 (2):109-136.

Cavanilles, A.J. 1799. Icones et descriptiones plantarum 5: est. 409-410.

Cowan, R.S. 1957. The Machris Brazilian Expedition Botany: Phanerogamae, Leguminosae. Contribution Los Angeles County Museum 13: 1-22, fig. 1-7.
De Candolle, A.P. 1825. Bauhinia. In: Prodromus. Paris. E. Treuttel \& Wurtz. 2:511-519.

De Wit, H.C. 1956. A revision of Malaysian Bauhinieae. Reinwardtia 3:381-541.

Donato, A.M. 1995. Anatomia foliar e abordagem fitoquímica de Bauhinia forficata Link (Leg - Caes.). Bradea 6 (42): 357-371.

Ducke, A. 1922. Leguminosae in: Plantes nouvelles oupeu connues de la région anazonienne II. Archivos do Jardim Botânico do Rio de Janeiro 3: 47-175. 1925a. Plantes nouvelles ou peu connues de la région amazonienne III. Archivos do Jardim Botânico do Rio de Janeiro 4: 12-99.

1925b. As leguminosas do estado do Pará. Archivos do Jardim Botânico do Rio de Janeiro 4: 211-342.

1939. As leguminosas da Amazonia brasileira. Serviço Florestal. Ministério da Agricultura. Rio de Janeiro.

1959. Leguminosae in: Estudos botânicos no Ceará. Anais da Academia Brasileira de Ciências 31: 253-299.

Dudik, N.M. 1981. Morphology of the Pods of Leguminales (Fabales). In: R. M. Polhill \& P. H. Raven, (eds). Advances in legume systematics, Kew, 1: 941 -950.

Ferguson, I.K. \& Pearce, K.J. 1986. Observations on the pollen morphology of the genus Bauhinia L. (Leguminosae: Caesalpinioideae) in the neotropics. In: Blackmore, S. \& Ferguson, I.K. (eds). Pollen and Spores: Form and Function. 283-296 p.

Fortunato, R.H. 1986. Revision del gênero Bauhinia (Cercideae, Caesalpinioidea, Fabaceae) para la Argentina. Darwiniana 27 (1-4): 527-557.

1996. Bauhinia affinis (Fabaceae) una nueva cita para la flora argentina. Darwiniana 34 (1-4): 405-409. 
Greuter, W. et al. 2000. International Code of Botanical Nomenclature. (Saint Louis - Code). (eds). Koeltz Scientific Books D61453 Konigstein, Germany.

Harms, H. 1903. Leguminosae in Plantae novae americanae imprimis glaziovianae. V. Bot. Jahrb. 33 (72): 21-22.

Hassler, E. 1911. Ex herbario Hassleriano: Novitates paraguariensis XII. Fedde Repert 9:147.

Hoehne, F.C. 1919. Leguminosas In: Commissão de Linhas Telegraphicas Estratégicas de Matto Grosso ao Amazonas. Annexo 5, Botânica parte 8: 1-100, t.132-159.

Holmgren, P.K., Holmgrem, N.H. \& Barnett, L.C. (eds). 1990. Index Herbariorum, part 1. the Herbaria of the World. ed 8, New York Botanical Garden, New York.

IUCN. 1994. Iucn Red List Categories. The World Conservation Union. Gland. Switzerland.

IBGE. 1960. Carta do Brasil ao milionésimo. Instituto Brasileiro de Geografia e Estatística. Rio de Janeiro.

Joly, C.A.; Aidar, P.M.; Klink, C.A. et al. 1999. Evolution of the Brazilian phytogeography classification systems: implications for biodiversity conservation. Ciência e Cultura 51 (5/6): 331-348.

Lewis, G.P. 1987. Legumes of Bahia. Royal Botanic Gardens, Kew.

Macbride, J.F. 1943. Flora do Peru (Bauhinia). Field Museum of Natural History. Botanical Series 13(1): 207-220.

Malme, G.O.A. 1905. Die Bauhinien von Mato Grosso. Arkiv for Botanik 5 (50): 1-15. 1930. Die Leguminosen der zweiten Regnellschen Reise. Arkiv for Botanik 23A 13): 1- 99.

Mendonça-Filho, C.V. 1996. Braúna, Angico, Jacarandá e outras Leguminosas de Mata Atlântica, Estação Biológica de Caratinga. Belo Horizonte. Fundação
Botânica Margareth Mee/Fundação Biodiversitas.

Metcalfe, C.R. \& Chalk, L. 1950. Caesalpiniaceae. In: Anatomy of the Dicotyledons. Oxoford Clarendon Press. Oxford. vol 1: 487-501.

Paviani, T.T. \& Magalhães, M.P. 1996. Propagação vegetativa em Casearia Sylvestris Sw. (Flacourtiaceae). In: Resumos XLVII Congresso Nacional de Botânica Nova Friburgo, Rio de Janeiro. p: 248.

Payne, W.W. 1978. A glossary for plant hair terminology. Brittonia 30: 239-255.

Pijl, Van der. L. 1952. The leaf of Bauhinia. Acta Botanica Neerlandica 1 (2): 287309.

Prado, D.E. \& Gibbs, P.E. 1993. Patterns of species distributions in the dry seasonal forests of south America. Annals of the Missouri Botanical Garden 80: 902-927.

Rezende, M.H. \& Cardoso, L.A. \& Vannucci, A.L. 1994. Morfologia e Anatomia foliar a Bauhinia curvula Benth. (Leguminosae - Caesalpinioideae). Acta botanica brasilica 8 (1): 19-34.

Rizzini, C.T. 1965. Estudos experimentais sobre o xilopódio e outros órgãos tuberosos de plantas de cerrado. Anais da Academia Brasileira de Ciências 37 (1):87-113. 1976. Tratado de Fitogeografia do Brasil. $1^{\text {o }}$ vol. Editora Hucitec, Universidade de São Paulo, São Paulo.

Rizzini, C.T. \& Heringer, E.P. 1961. Underground organs of plants from some southern Brazilian savannas, with special reference to the xylopodium. Phyton 17 (1): 105-124.

. 1962. Studies on the underground organs of trees and shrubs from some southern brazilian savannas. Anais da Academia Brasileira de Ciências 34 (2): 235-247.

Rusby, H.H. 1912. Bauhinia In: New species 
from Bolívia, collected by R. S. Williams 2. Bulletin New York Botanical Garden 8 (28): 92-93.

Solereder, H. 1908. Bauhinia. In: Systematic Anatomy of the Dicotyledons. Oxford, Clarendon Press. Oxford. vol.1, p.281-291.

Stearn, W.T. 1973. Botanical Latin. 2 ed. Devon, David \& Charles. Newton Abbot.

Tucker, S.C.; Rugenstein, S.R. \& Derstine, K. 1984. Inflated trichomes in flowers of Bauhinia (Leguminosae: Caesalpinioideae). Journal of the Linnean Society Botany 88: 291-301.

Turland, N.J. \& Jarvis, C.E. 1997. Typification of Linnaean specific and varietal names in the Leguminosae (Fabaceae). Taxon 45: 457- 485 .

Urban, I. 1885. Morphologie der Gattung Bauhinia. Berichte der Deutschen Botanischen Gesellschaft. 3: 81-101.

1906. Vitae itneraque collectorum botanicorum. In: Martius, C.F.P. von; Eichler, A.W. \& Urban, I.(eds). Flora brasiliensis. Munchen, Wien, Leipzig, v. 1 , part 1 .

Vanzolini, P.E. \& Papavero, N. 1968. Indice dos topônimos contidos na carta do Brasil 1: 1000 000. FAPESP.

Vaz, A M.S. da F. 1993. Trepadeiras do gênero Bauhinia no estado do Rio de Janeiro. Pesquisas ser. Botânica 44: 95-114.

.1995. Notas nomenclaturais em Bauhinia sect. Pauletia ser. Cansenia (Raf.) Wund. et al. (Leguminosae Caesalpinioideae). Atas da Sociedade Botânica do Brasil, secção Rio de Janeiro 3 (20): 1-4.

. 2001.Taxonomia de Bauhinia sect.

Pauletia

(Leguminosae:

Caesalpinioideae: Cercideae) do Brasil. Tese de Doutorado em Biologia Vegetal, Unicamp, Campinas.

Vaz, A.M.S. da F. \& Marquete, R. 1993. Espécies de Bauhinia L. (Leguminosae - Caesalpinioideae) de Brasilia, Distrito
Federal. Revista brasileira de Botânica. 16 (1): 101-113.

Vaz, A.M.S. da F. \& Tozzi, A.M.G. de A. 2003. Aculeatae, a new series in Bauhinia section Pauletia (Leguminosae, Caesalpinioideae, Cercideae). Novon 13 (1): 141-144.

Veloso, H.P. 1992. Sistema Fitogeográfico In: IBGE, Manual Técnico da Vegetação Brasileira. Série Manuais Técnicos em Geociências v. 1. Rio de Janeiro.

Vogel, J.R. 1839. Observationes de Bauhiniis Americanis. Linnaea 13: 298-315.

Wunderlin, R.P. 1976. Enumeration and typification of genera in the tribe Cercideae. Rhodora 78: 750-760. 1983. Revision of the arborescent Bauhinias (Fabaceae: Caesalpinioideae: Cercideae) native to middle America. Annals of the Missouri Botanical Garden 70: 95-127.

Wunderlin, R.P.; Larsen, K. \& Larsen, S.S. 1987. Reorganization of the tribe Cercideae (Fabaceae: Caesalpinioideae).

Det Kongelige Danske Videnskabernes Selskab 28: 1-40.

\section{ANEXO 1: LISTA DE EXSICATAS (COLETOR E N ${ }^{o}$ )}

$\mathrm{O}$ número entre parênteses corresponde ao número da espécie no texto.

Agra, M. de F., 284 (32)

Aguiar, O.T., 359, 509 (23)

Albuquerque, B.W. de, 1346 (11)

Alcoforado Filho, F.G., 339 (32)

Alencar, L., 167 (22)

Alencar, M.E., 244 (32); 245 (1); 526 (14); 609

(34d); 716 (28)

Almeida Conceição, C.A., 361 (28)

Almeida, S.P. de, 587 (20)

Alunos de Bot 5 sem.-1984, s/n RB (23)

Alvarenga, D., 1093 (1)

Amador \& Guerra, 69 (4) 
Amorim, A.A.M., 1695 (23)

Anderson, W.R. et al., 6644 (26); 6902 (18);

9488, 37025a (34a); 9908 (4) 9545, 10126 (13);

9719 (20); 9897, 12164 (22); 36417 (1)

Andrade, J.B. de, 2183 (4)

Andrade, L.M. \& M.A. Lopes, 319 (16)

Andrade, M.C. et al., 84 (20)

Andrade, P.M. \& M.A. Lopes, s/n BHCB 89920 (30); 363 (23)

Andrade-Lima, D. 56-2588, 56-2599, 66-4494, 71-6406, 76-8210, 79-9657 (32); 58-2936 (20); 66-4495 (9); 66-4531, 70-5802, 70-5845 (9); 664782, 70-5894 (34d) 70-5895, 79-9210, 79-9419 (28); 76-8261 (12); 79-8778 (1)

Andrade-Lima, D. \& M. Magalhães, 52-1108 (34d)

Angelica, s/n EAC 11867 (1)

Angelica \& Aglaene, s/n EAC 15196 (34d)

Angelica \& Margarete, s/n EAC 15509 (34d)

Antenor, s/n RB 452 (23)

Aquino, P., 3278 (23)

Aranha, C., 6019 (20)

Araújo Filho, O. et al., s/n VIC 18667 (34a); 730 (9)

Araújo, F.S., s/n RB 296140 (34d); 21 (32); 100 (1)

Araújo, G.M. de, 309, 534, 729, 801, 886 (34a); 423, 1005 (30)

Árbocz, G. 805, 107 (20); 805 (34a)

Argent, G. et al., 6481 (34a)

Arouck Ferreira, J.D.C., 424 (9)

Assakura, S.W., s/n FUEL (23)

Assis, J.A. op. RADAMBRASIL, s/n RB (3); $12(14)$

Assis, J.S. de, 075 (34c); 358 (9)

Atkins, S. et al., 5087 (9)

Azevedo, M.L.M., 1215 (1)

Balee, W. L. \& B. G. Ribeiro, 6 (14)

Barbosa, M., 2341 (23)

Barbosa, V.P., 99 (9)

Barbosa-Fevereiro, V.P., 470 (9)

Barçante, I., 218 (23)

Barroso, G.M., 63 (34d)

Barroso, G.M. \& E.F. Guimarães, 44 (14)

Bautista, H.P., 555 (23)

Bautista, H.P. \& O.A. Salgado, s/n RB (32)

Becker, R., 23 (20)
Belém, R.P., 1300, 1551 (23)

Belém, R.P. \& M. Magalhães, 743, 996 (23)

Belem, R.P. \& R. S. Pinheiro, 2208, 2260,2296, 2403 (23)

Bento Pena op. RADAMBRASIL, s/n RB 180719, RB 187759 (11)

Berardi, H.Z., s/n GUA 26403 (23)

Bergallo, H. de G., 21043 (34b)

Bernacci, L.C. et al., 844, 1855 (20); 1158, 34950 (23); 1626, 34962 (34a); 2240 (4)

Bertoncini, A.P. \& M.P. Bertoncini, 826, 845 (23)

Bertoni, 18663 (20)

Bezerra, P., s/n EAC 1110, 546 (9); 298 (34d)

Bicudo, 167, 238, 301 (20)

Blanchet, 2861 (1)

Bona Nascimento, 212 (14)

Bona Nascimento, M.S., 215, 473 (32); 1082 (34d)

Bona Nascimento, M.S. \& J.H. de Carvalho, $602(34 \mathrm{c})$

Bona Nascimento, M.S. \& M.E. Alencar, 1080 (28)

Boone, W., 206 (23)

Borges, H.B.N., 35452 (4)

Brade \& Barbosa, A., s/n RB (23)

Brade, A.C., 5651 (23); 13686 (4)

Braga, J.M.A. \& M.B. Loureiro, 3748 (20)

Brandjes, N. B. M., 100501 (22)

Braz, E., s/n IPA 53022 (9)

Brina, A.E., s/n BHCB (34a)

Brina, AE. \& L.V. Costa, s/n BHCB 36279

(23)

Bruce Nelson, 810 (22)

Bucci, F. \& F.R. de Jesus, 126 (34c)

Burchell, s/n fotografia RB (31); 5590, 6322

(4);8398 (14)

Cabrera, E. \& H. de Cabrera, 10720, 10840 (34d)

Calderon, C.E. et al., 2523 (34d)

Calzada, J.I., 87 (34d)

Camargo, J., 2 (23)

Campbell, D.G. et al., P21873, P22531 (22)

Campos Porto, P., 2560 (4); 2659 (23)

Campos, W.G., 19 (23)

Carauta, J.P.P., 764 (20); 3741, 4295, 4681 (23)

Cardoso da Silva, F. C. et al., 297 (12) 
Carreira, L. et al., 444 (22)

Carvalheira, R., s/n JPB 3444 (9)

Carvalho, A., 52 (34a)

Carvalho, A.M., s/n CEPEC (4); 115, 1305 (23); 1732, 2897 (28); 1760 (1)

Carvalho, A.M. de \& G. Bromley, 198 (23)

Carvalho, D.A., s/n RB 295591 (23)

Carvalho, G.H., 17 (1)

Carvalho, L.F., 532 (23)

Carvalho, M.A. de 3958 et al., 3958 (32); 4034

(28)

Carvalho, O. de, 11 (34d)

Casas, J.F. \& J. Grimes, 3973 FC (34d)

Castillo, A., 3394 (22)

Castro, A.J. \& E. Nunes, s/n EAC 6424 (28)

Cavalcante, P. \& M. Silva, 2628 (13); 2807 (2)

Cavalcanti, D.C., 146 (23)

Cavalcanti, F.S., s/n EAC 18514 (14)

Cavalcanti, T.B. et al., 845, 1518 (34a); 1474

(4); 1998 (4)

Cervi, A.C. et al., 3365 (34a)

Cesar, R., 572 (4)

Cézio, 571 (12)

Chagas e Silva, F. das, 1469 (23)

Chiappeta et al., s/n CFPE 519 (1)

Cid Ferreira, C.A. et al., 327 (10); 1428, 5393, 7400 (22); 4306, 4618, 4633 (4); 5011 (24)

Cid, C.A. \& J. Lima, 3826 (10)

Claussen, P., 17 (16); 144, 477 (4)

C.M.M., 47 (23)

Coelho, D. et al., s/n A (22)

Coelho, L., 154 (22)

Collares, J.E.R. \& A. da Silva, 201 (9)

Collares, J.E.R. \& L. Dutra, 139 (9)

Collares, J.E.R. \& M.M. Fernandez, 127 (1)

Con. Capanema, s/n RB 5106 ( 23)

Conceição, C.A., s/n RB 298104 (20)

Coradin, L. et al.,2035, 5813, 5816, 6064, 8628

(28); 2179 (18); 2449 (9); 3731 (34a ) 3740 (12); 5720, 5749, 6351, 7597 (4);

6594 (32); 6621, 6639, (1); 8705 (23)

Cordeiro, M. dos R., 50 (28); 214, 493 (34d)

Correa Franco, s/n SPFR (23)

Correia, M., 436 (32)

Costa Lima, G., 59 (9)

Costa, J.M., 070 (34c)

Costa,L.V.,s/n BHCB 26210, 1996 (30); s/n
BHCB 27637, DIJ 343 (34a); s/n BHCB 40895

(1)

Croat, T.B. \& D.P. Hannon, 63312 (34d)

Cunha, C.N., 497 (52); 2054 (34a)

Cunha, J.A. da, s/n 10700 (23)

Cutler, H.C., 8132 (34d)

DAC et al., s/n UEC (20)

Dahlgren, B.E. \& E. Sella, 117 (24)

Daly, D.C. et al., 1787 (22)

Damazio, L., s/n RB 38717 (30); s/n RB 38718, s/n RB 38737 (23); s/n RB 38725, s/n RB 38722 (16)

Dambrós, L.A., 283 (23)

Davidse, G., 5339 (34d)

Davidse, G. \& Gonzalez, 14102 (12)

Davidse, G. \& T. P. Ramamoorthy, 10543 (20)

Davis, P. H. \& G. J. Shepherd, D60006, 60052 (15a)

Davis, P. H., 2401 (1); 2425 (4); 2500 (30); 60127

(15a)

de Paula, J. E., 3427 (34d)

Dedecca, D. M. \& Swiercz, 569, 585 (4); 586 (34a)

Del'Arco, M. \& A. Ferandes, s/n UEC (9)

Del'Arco, M. et al., s/n UEC (14)

Dias, A.A. \& Bento Pena, 45 (11)

Dias, W.A.A., 11 (12)

Dionizia, F. et al., 164 (24)

Drouet, F., 2620 (34d)

Duarte, A.P., s/n RB, 3827 (23); 340 (39); 3004 , 8217 (34a); 4200 (45); 7217 (34d); 7258 (10) 8255 (12); 8330 (25); 8478 (30)

Duarte-Almeida, J.M., 01 (30)

Ducke, A., s/n RB 16953, s/n RB 23419, s/n MG 16855, 938 (19); s/n MG 7109, s/n RB $24305 \mathrm{~s} / \mathrm{n}$ MG 16020, s/n RB 23300,s/n RB 35432, 665 (22); s/n RB 23303 (23); s/n RB 16954 (24) s/n MG 16864, s/n MG 17101, s/n RB16955 (24); s/n RB 23303 (20); s/n MG 540, 16958 (14); s/n RB 20322, 958 (34b); s/n RB 11130 (34d) s/n MG 17153, s/n EAC 993, s/n RB 20323, s/n RB 11129, 131, 1335 (34d); 16959 (2)

Durigan, G., s/n SPSF 14535, s/n SPSF 30712 (23)

Dusen, P., 10938 (20)

Dutra, E. de A., 39 (9)

Egler, W.A., 1319 (22) 
Egler, W.A. \& H.S. Irwin, 46053 (34d)

Eiten, G., 2042, 2951 (20); 3078 (34a)

Eiten, G. \& L.T. Eiten, 4133, 4603, 10489 (32); 4579 (28); 5495 (3); 8314, 9304 (34a); 10649 (34c)

Emígdio, L. \& J. Vidal, 305 (23)

Emperaire, L., s/n RUSU (1)

Evangelista Oliveira, J., s/n RB (4)

Faria, S.M. de, 430 (23); 1759 (16)

Farias, G.L., 193 (23)

Felfili, J.M. et al., 322 (8); 394 (34a)

Félix, L.P., s/n EAC 19861 (32)

Fernandes, A., s/n EAC 2770 (1), s/n EAC 8726, s/n EAC 11265, s/n EAC 15371 (4); s/n

EAC (14); s/n EAC 1609, s/n EAC 1656 (9)s/ n EAC (12); s/n EAC 2444 (28); s/n EAC 8685, s/n EAC 8696 (28); s/n EAC 1731 (34d); s/n EAC 9093 (1)

Fernandes, A. \& E. Nunes, s/n EAC 8428 (32); s/n RB 329335, s/n EAC 8544, s/n EAC 8394 (9) s/n EAC 15454 (9); s/n EAC 8416, s/n EAC 8825 (28); s/n EAC 8459 (34b)

Fernandes, A. \& A. Figueiredo, s/n EAC 112292 (1)

Fernandes, A. \& A.J. Castro, s/n EAC 6075 (28) Fernandes, A. \& Del'Arco, s/n EAC 9978 (4) Fernandes, A. \& Matos, s/n EAC (3); s/n EAC 3209, s/n EAC 6621 (9); s/n EAC, s/n EAC 3098 (14) s/n EAC 20277 (14); s/n EAC 3147(28); s/n EAC 13093 (32); s/n EAC 13312 (34d)

Fernandes, A. \& P. Martins, s/n EAC 9832 (1); s/n EAC 8278, s/n EAC 9680, s/n EAC 12360 (14); s/n EAC 10418 (28); s/n EAC 10425 (34d) Fernandes, A. \& V. Rodrigues, s/n EAC 10615, s/n EAC 11270 (4); s/n EAC 10603, s/n EAC 10734 (12)

Fernandes, W., s/n RB 313770 (4)

Ferreira, D. F. et al., 95 (34a)

Ferreira, H. D., 241, 2468 (34a)

Ferreira, H. D. \& R. C. A. Balieiro, s/n UFG 14383 (13)

Ferreira, V. F., 1100, 3222 (23)

Figueiredo, M.A. \& A. Fernandes, s/n EAC 16474 (14)

Figueiredo, M.A. \& M.B. Diogenes, s/n EAC 16119(14)
Figueiredo, M.A., s/n EAC 25673 (14); 306 (9)

Filgueiras, T.S., 415 (8); 1428 (4)

Filgueiras, T.S. \& D. Alvarenga, 1530 (20)

Fisher, E. A., 23033 (34a)

Flores, G., F940 (34d)

Fonseca Vaz \& H.M. Vaz, 935 (23)

Fonseca, A.S. da, 68 (30)

Fonseca, M., s/n ASE, 495, 868 (9)

Fonseca, M.L. et al., 80, 1035, 1093, 1535 (15a); 629 (26); 1857 (1); 1925 (12); 2003 (4); 2270

(27)

Fontella Pereira, J., 717 (30)

Foster, R.B., 8687 (22)

Frame, D. et al., 107 (34b)

França, F. et al., 966, 1307 (28); 2157 (9)

Franco, C.M., 3921 (23)

Frei Allemão \& M. de Cysneiros, 486 (1)

Freire-Fierros, A. et al., s/n CFCR 12569 (1)

Fróes, R.L., 29999 (3); 27113 (34b); 29941 , 30150 (12); 30939 (24)

Fróes, R.L. \& G.A. Black, 24323 (34b)

Gabinete de Bot. e Zoologia, Fac. Medicina do RJ, s/n RFA (23)

Ganev, W., 092, 3359 (28); 553, 1545 (23)

Garcia, W.G., 13710 (20); 13996 (34a)

Gardner, G., 1567, 2531 (34d); 2153, 6008 (14);

2154 (1); 2155 (9); 2529 (12); 2530 (4);

3120, 3695 (27); 3698 (31); 3696 (17); 4537,

$5444(23)$

Gehrt, G., s/n SP (34a)

Gibbs,P.E. et al., 2005 (23); 2652 (4); 5336, 5445, 5484 (34a); 5482 (28)

Giochetto, T.V. \& A. Bernardo, s/n SJRP 9964 (34a)

Giulietti, A.M. et al., s/n CFCR 2206, s/n CFCR 2458 (30)

Glaziou, A., 2979, 8411, 13736, 19062 (23);

10688 (9);12623 (34a); 21012a (15a); 21014 (30)

Godoi, J.V., 68 (23)

Góes, G.C. \& D. Constantino, 947 (23)

Gomes, M., 99 (23)

Gonçalves, L.M., 185 (28)

Granville, 6876 (10)

Grecco, M.D.N. et al., 56 (20); 114 (34a)

Grupo Pedra de Cavalo, 356 (9)

Guanchez, F. \& L. Mercado, 1932 (22) 
Guimarães, J.G., 44 (13)

Hage, J.L., 2175 (23)

Harley, R.M. \& V.C. Souza, H50106 (28)

Harley, R.M. et al., 10643 (12); 18948, 28575

(1); 16858, 18995, 19810, 21237 (28); 21157 (4) 21829 (4); 21609 (32); 21677 (23); CFCR 5904 (30)

Hassler, s/n W (23)

Hatschbach, G. et al., 3123, 17607, 35520 (23); 38458, 41386, 42555, 44529, 54009, 61871, 69807, 52861, 62284, 62586 (23) 14277, 31162, 34155, 58701, 62066 (20);21849, 62289, 62815 (4) 70881 (4); 25046 (7); 36740, 54018 (33); 36809 (8); 38410, 56043 (14); 40899, 55132, 55155, 65926, 66017, 67291, 67683, 67957, 68986, 71305 (1) 55856, 67219 (30); 56506, 56570, 62033, 62291, 65023, 65145, 67644, 67660, 67799 (28) 70831, 71003 (28); 60452, 62835 (18); 65975 (41); 66470 (12); 70975 , 70845 (27)

Hatschbach, G. \& J. Saldanha, 55284 (23)

Hatschbach, G. \& J. M. Silva, 65283 (23); 54588 (15b)

Hatschbach, G. \& O. Guimarães, 22034 (34a) Hatschbach, G. \& R. Kummrow, 38459 (46); 35042 (7)

Heringer, E. P., 392, 699, 823, 114 (9); 760 (1); $818 ; 3288(4) ; 7578,14692,15882$ (34a); 9238/ 1451, 14604 (13)

Heringer, E.P. \& Rizzini, s/n RB (34a); 7559 (30)

Hill, S.R., 12916 (22); 17612 (34d)

Hoehne, F.C., s/n RB (23); 1990 (13)

Horta, M.B. et al., s/n BHCB 22137 (1); DIJ/ 204-2 (9)

Huber, s/n MG 4661 (10)

Irwin \& Soderstrom, 6886 (12)

Irwin, H.S. et al., 2566, 21679 (18); 7102, 16735, 16840,16919, 17043 (4) 17774 (4); 8372 (25); 9426, 24732 (26); 11007 (18); 12460, 24397, 24753 (33); 14911 (28) 2811, 13441, 31186 (1); 13689, 15435, 34645, 16563, 16865 (13) ; 13727, 16733, 25499 (20) 14979, 15986, 17113, 17390, 24614 (23); 16225, 16300 (22); 16991, 17608 (12); 16819 (6); 17089, 17479 (34a); 21128, 21386 (14); 21161 (5); 21264 (34c); 21506 (3) 21557, 21713 (5); 2335 (30);
24118, 24230 (29); 48053 (10)

Irwin, H. S. \& R.R. dos Santos, 10518 (20)

Irwin, H. S. \& T.R. Soderstrom, 6209 (34a); $6263(25)$

Ivanauskas, N.M. 4427 (12)

Jaccoud, 16 (34a)

Jacinto \& Lima, s/n RB (23)

Jacques, E.L., 457 (53); 514 (34a)

Jangoux, J. \& R.P. Bahia, 365 (14); 1057 (28)

Janzen, D.H., 565 (34d)

Jasen-Jacobs, M.J. et al., 2239 (34d)

Joly, A.B., 885 (20)

José \& A. Simões, 01 (23)

Kameyama, C. et al., s/n CFCR 9019 (1)

Kassin, A., 2688, 2696 (36)

Killeen, T., 6297 (4)

Killeen, T. \& H. Gonzáles, 6420 (4)

Kirizawa, M. et al., 605 (20)

Kirkbride, J.H., 2658 (34d)

Klein, R.M., 9802 (39)

Klein, V.L.G. et al., 2066 (13); 2071 (30); 2399

(23); 2420 (25); 2644 (20)

Konno, T. et al., 242 (23)

Krapovickas, A., 14404 (34a); 14406 (20)

Krapovicks, A. \& A. Schinini, 36279 (4)

Krukoff, B.A., s/n 5 exp. US, 4680, 8410 (10); 1037 (34d); 1076 (34b)

Kuhlmann, J.G., 15 (14); 52 (23); 81 (16); 902, 1823 (22); 1082 (34d); 2024 (28)

Laclette, P., 920 (23); 924 (34a)

Laroca, S., 11 (34a)

Lasseigne, A., 4364 (13)

Leal Costa. A., s/n HUEFS 1387 (3)

Leitão Filho, H. F. et al., s/n IAC 19172 (23);

36 (4); 139 (42a); 2057 (28); 11676 (20)

Leitão Filho, H.F. \& G. Shepherd, 4002 (23)

Leitman, M., 186 (23)

Leonardos, O.H., s/n RB (4)

Leoni, L.S., s/n GFJP 1503 (16); s/n GFJP 1505 (23)

Lewis, G.P. et al., s/n CFCR 6800 (28)

Lima, A., 58-2943 (13); 58-3116 (4)

Lima, A.S., s/n IAC 7407 (20)

Lima, D.P., 13334 (28)

Lima, H.C de, s/n RB 208213 (34d); 954 (1);

967 (34a); 1560 (14); 3878, 3984 (9); 4110 (23)

Lima, I.V., 131 (5) 
Lima, M.P.M. de et al., 99 (24); 149 (23)

Lima, V. C., 385 (9)

Lima-Verde, L.W., 432 (9)

Lindman, C.A.M., A3291 (4)

Loefgren, A., 1379 (23)

Lombardi, J.A., 1785 (23)

Lombardi, J.A. 1665 \& A. Salino, 1665 (34a); $1696(1)$

Lombardi, J.A. \& F.R.N. Toledo, 435 (30)

Lopes, R.D. et al., 22 (33)

Lowrie, S.R. et al., 264 (34d); 549 (11); 639

(22)

Lucidalva, 05 (13)

Luetzelburg, 1784 (34d); 26908 (9)

Lutz, A., 83 (20); 429 (4); 1017 (23)

Lutz, B., s/n R 15927, 1485 (23)

Lyra, R. P. de \& M. N. Stavis, 584 (9)

M. \& Alencar, 255 (32)

M.F.B., 211 (3)

Macedo, A., 389 (4); 3879 (12); 3900 (34a);

4079 (20)

Machado, O., s/n RB 433 (34a)

Magalhães, F.M.R., 14 (20)

Magnago, H., 249 (13)

Maguire, B.S. et al., 56117 (34a); 56527 (22)

Malme, G.O.A., 1643, 1643a, 1643b, 1643c, 1643d, 1643e, 1643f (34a); 273a, 273b, 273c (21); 1641a (4); 1641b (4); 1641a (12); 1757, 2515, 2515a (6) 2515b, 2515c (6); 3490 (13); $3266(23)$

Malme, G.O.A. Pl. IT. Regneli II, s/n S, 2627 (9)

Mamede, M.C.H. et al., 25 (15b)

Mantovani, 1349 (20)

Marcondes-Ferreira, W. et al., 378 (34a); 983

(20)

Margarida, s/n EAC 5396 (34d)

Margon Vaz, H., 07/98 (23)

Marquete, R., 321 (20); 1529 (23); 2121, 2288, 2299 (15a); 2123 (30)

Martinelli, G. et al., 129 (23); 367 (20); 2187

(23); 11190 (28)

Martinez, E., S11234 (34d)

Martins, F.R., 70 (20); 16864 (23)

Martins, P., s/n EAC 8201 (9)

Martins, P. \& E. Nunes, s/n EAC 7736 (1); s/n

EAC, s/n EAC 7468 (14); s/n EAC 7518 (28);
Martius Iter. Brasil, 6219 (15a)

Mattos, J. \& N. Mattos, 14456, 16305 (23)

Mattos, L.S. et al., 3047 (23)

Mechi \& Mateus, 169 (20)

Meira Neto, J.A.A., 19, 584 (34a); 397 (20)

Mello Barreto, 5841 (4)

Mello-Silva, R., 453 (28)

Melo, E. de et al., 1971, 2101 (9)

Mendes Magalhães, 156 (13); 271 (23); 293

(34a); 2207

Mendes, I.A.C., 31 (4)

Mendes, M.R.A., 163 (14); 289, 338 (9)

Mendonça Filho, C.V. et al., 146 (23)

Mendonça, R.C., 1465 (32)3182, 3412, 3423, 3425 (1); 3414, 3458 (28)

Mesquita, M. R. et al., 79 (34d)

Mexia, Y., s/n S (34a); 4946, 4981 (23)

Mileski, E., 89 (20); 308 (14)

Miller, J.S. \& P. Tenorio, L564 (34d)

Miranda, C.A., 40, 52, 105, 135 (1); 119 (14)

Miranda, I.S. \& P.J.D. Silva, 1527 (4)

Miyagi, P.H. et al., 542 (23)

Montanholi, R., 47 (20); 179, 195 (23)

Monteiro, J.R.B. \& H.F. Leitão Filho, 21 (23)

Monteiro, M., 1715 (4)

Moreno, P., 5302 (34d)

Mori, S.A. et al., 16706 (34a)

Mostacedo, B. et al., 2654 (9)

Mota, A.L.P. et al., 1196 (34a)

Muniz, C.F. S., 335 (34a)

Murça Pires, J. \& G.A. Black, 2323 (34d); 2347 (34c)

Murça Pires, J. \& M.R. Santos, 16120 (34b); 16157 (34a)

Murça Pires, J. \& P.B. Cavalcante, 52334, 52416 (34d)

Murça Pires, J. \& R.P. Belém, 12390 (34b)

Murça Pires, J. et al., 904 (22); 9230, 9706 (34a); 51053 (34d)

Nakajima, J.N. et al., 95, 97 (30)

Nascimento, M.S.B., 528 (27)

Nascimento, O.C., 409 (14)

Nave, A.G. et al., 1009 (4)

Neves Armond, 13 (23)

Neves, R., s/n RUSU (23); s/n RUSU (34a)

Noronha 1293, 1476, 1582 (20)

Nunes, E. \& A. Fernandes, s/n EAC 8806 (32) 
Nunes, E. \& Angelica, s/n EAC 10105 (9)

Nunes, E. \& P. Martins, s/n EAC 5912 (3); s/n EAC 5818, s/n EAC 5917 (28); s/n EAC 5869 (32); s/n EAC 5858 (33); s/n EAC 8665 (34d) Nunes, E. \& Ribamar P. Soares, s/n EAC 11848, s/n EAC 12347 (9)

Nunes, E. et al., s/n EAC 11587 (9); s/n EAC 13859 (34d)

Núñez, P., 12254 (34d)

Nyenhuis, J.J., s/n FUEL (23)

Occhioni, P., 7405 (9)

Oliveira Filho, A., 271 (4); 272 (23); 273 (34a)

Oliveira, E., 1466 (34c); 6197 (34b)

Oliveira, F.C.A., 338 (13); 443, 444 (30); 499, 537 (23); 805 (15a)

Oliveira, J. E. de, s/n R (34a); 484 (16)

Orione, 2633 (4)

Orlandi, R.P. \& C.B. de A. Boherer, 653 (34d)

Orlandi, R.P., 354 (28); 394 (1)

Palmer, E., 436 (34d)

Paschoal, E.S., 1784 (23)

Peixoto, A.L., 872 (23)

Pereira, B.A.S. \& D. Alvarenga, 2816 (4)

Pereira, B.A.S. et al., 1508 (15b); 1579, 2998

(1); 1629 (23); 2524 (28) 2536 (34d); 2692 (30); 3115 (12)

Pereira, C., 342 (4)

Pereira, E. , Engler \& Graziela, 432 (21)

Pereira, E., 2379 (20); 3050 (16); 8957 (1) 10725

(4)

Pereira Neto, M., 451 (1)

Pereira-Noronha, M. R., 620, 1204, 1426, 1481(34a); 699 (4)

Pereira, R 368 et al., 368 (32); 1993 (1)

Pessoa, S. de V. et al., 703 (23)

pessoal do horto florestal, 37 (23)

Philcox, 3117 (22)

Pinto, G.C.P., 127/81, 132/84, (9); 225/81 (1)

Pinto, P. \& C. Sastre, 1312 (12)

Pirani, J.R. et al., s/n CFCR 915, s/n CFCR 12395, 2166 (1); s/n CFCR 13179 (28); 20-77 (34a); 3179 (20)

Pires, J.M. \& G.A. Black, 1645a (3); 2459 (12)

Pires, J.M. \& R.S. Santos, 16166 (3)

Pires, J.M. \& R.T. Martin, 9943 (23)

Pires, J.M., 51482 (10); 56856 (22); 56969 , 57897 (4)
Plowman, T. 8131 et al., 8131 (5); 8482 (24);

9361, 9633 (14)

Pohl, s/n OXF (20); 608, 3439 (30); 1098 (28); 5280 (23)

Poliquesi, C.B. \& E. Barbosa, 277 (23)

Pott, A., 1826 (34a)

Pott, V. J. et al., 822 (21)

Prance, G. T. \& N. T. Silva, 58210 (18); 58487

(3); 58488, 59325 (12); 58498 (34c)

Prance, G.T. \& J.F. Ramos, 6964 (34d)

Prance, G.T., 4100, 4132, 4299, 5573, 5655, 5881, 5915, 9145, 9556, 14434, 18208 (34d); 5901 (11); 8911 (37); 12579, 13424, 15342, 15850, 16397, 20705 (22), 9202 (34d)

Queiroz, L.P. \& N.S. Nascimento, 3391, 3469, 3842, 3946, 4615 (9); 3934 (1); 4119 (4)

Queiroz, L. P. de et al., 3857 (28)

Quevedo, R. \& T. Centurion, 449 (4)

Ramalho da Silva, R., 293 (23)

Ramalho, F.B., 226 (4)

Ramos, A.E., 867 (14)

Ratter, J.A. \& J. Fonseca Filho, 3286 (20)

Ratter, J.A. \& R.R. dos Santos, 1625 (23)

Ratter, J.A. et al., 4871 (20); R6783 (14)

Regnell, A.F., 490, 493 (23); 491 (34a)

Rezende, M.H., 4, 54 (4)

Rezende, M.H. \& H.D. Ferreira, 5, 12, 13 (13)

Rezende. A.V. et al., 119 (1)

Ribas, O.S. \& L.B.S. Pereira, 761, 2559 (20);

2372 (23); 2419 (9)

Ribeiro Jr., s/n FUEL (20)

Riedel, s/n OXF (4); s/n OXF (9); s/n OXF (16); s/n OXF (20); s/n C, OXF, SI, W (23) s/n C, OXF (34a)

Rizzini, C.T. \& A. Mattos Filho, 1571 (1)

Rizzo, J.A. \& A. Barbosa, 857 (13)

Rizzo, J.A. et al., 4804, 6317 (13); 5267, 8113, 8167, 9233, 9815 (34a); 6465 (4) 7752 (27)

Rocha, D.M.S., 11369 (4)

Rodal, M.J.N., s/n IPA (9)

Rodrigues, I.A., 309 (9)

Rodrigues, R.R. et al., 68 (34a)

Rodrigues, W. \& J. Chagas, 4493 (19)

Rodrigues, W.A., 817 (22); 10339 (4)

Rodrigues, W.A. \& F. Mello, 4349 (34d)

Rojas, L., 2686 (9)

Romero, R. et al., 467 (30) 
Rosa, F.R., 22 (23)

Rosa, N.A. \& M. R. Santos, 1945 (22); 2032 (34d)

Rosa, N.A., 3083 (34d); 4653 (34b)

Rosário, C.S., 14, 968 (34b)

Rosas, A. et al., 211 (22)

Rossi, L. et al., s/n CFCR 1017 (28)

Rueda, R., 889 (34d)

Salgado, O.A. \& H. P.Bautista, 299 (32)

Salgado, O.A., 21 (1); 150 (4); 255 (34a)

Salino, A., 3905 (14)

Sampaio, A., 4442, 6-1922 (23)

Sanaiotii, T.M., 197 (22); 466 (20)

Sandoval, E., 895 (34d)

Sanots, J. dos, 5188 (4)

Santin \& Cielo Filho, 31070 (20)

Santos, E. et al., s/n HTINS 2219 (12); 2594 (23)

Santos, F.S., 41 (23)

Santos, H.G.P. dos, 58, 64, 131 (23)

Santos, I., s/n s/herb., 22 (34a)

Santos, J. dos, S280 (20)

Sarmento, A.C., 576 (34c); 594 (3); 649 (4); 788 (28)

Sazima, M., 63 (23); 35734 (34a)

Scheiner, P., 15 (20)

Schmalzel, R.J., 1341 (34d)

Schott, 5635 (16)

Schwacke, 14-206 (34a); 422 (14); 3700/III619 (19); 3705/III-659 (34d); 13722 (30)

Sciamarelli, A. \& J.V.C. Nunes, 653 (23)

Semir, J., s/n UEC 6230 (29)

Serviço florestal da comp. paulista de estr. de ferro, s/n R (23)

Setz, E., 12431 (20)

Shepherd, G. J. et al., 3687 (15b); 7098, 11306

(20); 7454 (34a)

Sidney, 1461 (34a)

Silva, A. F., 1351, 8864 (23)

Silva, A.M., s/n RB (20)

Silva, A.S. et al., AS79 (3); AS189 (34b)

Silva, G. P. da, 3246 (14)

Silva, J. de S., 681 (4)

Silva, J.S. 171 (34a)

Silva, M. \& R. Souza, 2498 (34b)

Silva, M., 1919 (22); 2260 (24)

Silva, M. A. da et al., 1138, 2166 (4); 1277,
1738,1825 (1); 1517, 1747, $1816(28) ; 1993$ (26)

2082 (29); 2381 (23); 3834 (18); 3927 (34a);

1747, 4039 (22); 4322 (27)

Silva, M.F.F. da et al., 37 (24); 350 (34d)

Silva, M. G. \& C. Rosário, 5426 (34d)

Silva, M.G., 6296 (34b); 6461 (23)

Silva, M.R., 328, 413 (34a); 704 (20)

Silva, M.R. \& C.E. Rodrigues Jr., 1120 (34a)

Silva, S.M., 1345 (13)

Silva, S.S., s/n RB 187783 (28)

Silveira, M. et al., s/n FUEL (23)

Silveira, R.G., s/n RB 322168 (23)

Simão, R., s/n CFSC 10119 (23)

Skorupa \& Silveira, 470 (33)

Skorupa, L.A. \& J. N. Silveira, 470 (34c)

Skorupa, L.A., 601 (12)

Smith, D., 1873 (22)

Sobreia, M.M. et al., s/n FUEL (23)

Solomon, J.C., 7963 (22)

Soria, N., 4469 (9)

Soto Núñez, J.C., 3706 (34d)

Souza, H.M. de, s/n IAC 19585, 28, 1055 (20); s/n IAC 19640 (34a)

Souza, J.M.A. de et al., 180 (34d)

Souza, L.M. de et al., 221 (34a)

Souza, V.C. \& J.P. Souza, 11414 (34a)

Sperling, C.R. \& S. King, 6414 (22)

Spruce, R., 1413 (19)

St. G. Beck , 6572 (22)

Stannard, B. et al., 5433 (1)

Stehmann et al., 1208 (16)

Steinbach, J., 2892 (38)

Stevens, W.D., 5441 (34d)

Steward, W.C., 416, 475 (22)

Storti Filho, A., 4236 (20); 4238 (34a)

Stranghetti, V., 96 (23); 354 (34a)

Strudwick, J.J. et al., 4129 (34d)

Sucre, D. \& J.F. da Silva, 9209 (34d)

Sucre, D., 1489 (34a); 5553, 7093, 10191 (23); 10253 (34d)

Tamashiro, J.Y., T144, 932, 1133 (23); T203, T276 (34a); T205, T346, T395 (20)

Tameirão Neto, E., 68, 441, 642 (23); 1443 (34a); 1458 (30); 2057 (34a); 2160 (20)

Tavares, A.S., 166 (34b)

Tenorio, P. et al., 2931 (34d)

Tessmann, G., 60/25 (23) 
Thomas, W.W. et al., 5209 (34d); 10413 (23)

Tiritan, O. \& M., 50, 53 (28)

Tiritan, O. \& M. Paiva , 561, 595 (20)

Toledo, C.B. et al., 107 (26)

Toledo, F.R.N. \& J.A. Lombardi, 403 (20)

Tozzi \& Santos, 94-189 (20)

Tozzi, A.M.G.A. et al., 96-12 (23); 96-16 (34a); 96-30(20)

Tozzi, A.M.G.A. \& M.C. Dias, 94-27 (23)

Trinta, Z.A., 661 (20)

Turma da Farmácia, s/n JPB 2857 (9)

Uhlmann, A. \& Mendonça, 41 (20)

Ule, E., 28 (23); 5542 (35)

Urbano, 8441 (16)

Vale, L. \& R. Kirmse, s/n EAC 9945 (14)

Vargas, C., 18817 (37)

Vasconcellos, M.B. \& C.N. Cunha, 13587 (34a)

Vasconcellos, M.B. et al., 21654 (20)

Vauthier, s/n W (4); s/n W (16)

Vaz, A., 86, 760,1007, 1035, 1058 (13); 116, 380

(12); 396, 790, 936, 1059 (34a) 404 (34c); 601

(29); 817, 1002, 1071, 1106 (15a); 850 (33); 971, $1003,1057,1067(4) ; 847,8691008,1138,1139$

(18); 1036 (1); 1156 (8); 884, 1177 (26); 917

(20) 888 (25); 890 (15b); 906 (14)

Vaz, A. \& Quinet, A., 1034 (23)

Vaz, H.M., s/n RB, s/n RB 325657 (13); 01/98

(34b); 02/98 (12)

Viana, G., 622 (9)

Vianna, M.C. et al., 1517 (23)

Vidal, J., 36855 (20)

Vidal, W.N. et al., 425 (4)

Vieira, C.M. et al., 584 (23)

Vieira, M.C.W., 766 (23)

Vieira, M.G., 569, 945 (22); 676 (20)

Vieira, R.F. \& J.B. Pereira, 735 (18)

Vieira, R.F. et al., 1052 (34a); 1776, 1887 (4)

Walter, B.M.T. et al., 272 (4); 2457 (18) ; 2599 (12); 3325 (34a)

Webster, G. L. et al., 25009 (23); 25284 (34a)

Wendt, T. \& C.L. Oliveira, 5 (23)

Weyland, M.C., 172 (23)

William, 485 (11)

Windisch, P. \& L. Amorim, 6149 (4); 6219 (34a)

Windisch, P.G. et al., 6882 (34a)

Wurdack, J.J. \& J.V. Monachino, 39861 (12)

Xavier, L.P., s/n JPB 1762 (9)
Zanandreia, F.G. et al., 10 (34a)

Errata do Anexo 1: O número (28) corresponde a coleções identificadas como Bauhinia pulchella Benth. e o número (29) a Bauhinia platyphylla Benth. 